Argonne

\title{
Lithium-Ion Battery Supply Chain for E-Drive Vehicles in the United States: 2010-2020
}

Energy Systems Division 


\begin{abstract}
About Argonne National Laboratory
Argonne is a U.S. Department of Energy laboratory managed by UChicago Argonne, LLC under contract DE-AC02-06CH11357. The Laboratory's main facility is outside Chicago, at 9700 South Cass Avenue, Lemont, Illinois 60439. For information about Argonne and its pioneering science and technology programs, see www.anl.gov.
\end{abstract}

\title{
DOCUMENT AVAILABILITY
}

Online Access: U.S. Department of Energy (DOE) reports produced after 1991 and a growing number of pre-1991 documents are available free at OSTI.GOV (http://www.osti.gov/),

a service of the US Dept. of Energy's Office of Scientific and Technical Information.

Reports not in digital format may be purchased by the public from the National Technical Information Service (NTIS):

U.S. Department of Commerce

National Technical Information Service

5301 Shawnee Road

Alexandria, VA 22312

www.ntis.gov

Phone: (800) 553-NTIS (6847) or (703) 605-6000

Fax: (703) 605-6900

Email: orders@ntis.gov

Reports not in digital format are available to DOE and DOE contractors from the Office of Scientific and Technical Information (OSTI):

U.S. Department of Energy

Office of Scientific and Technical Information

P.O. Box 62

Oak Ridge, TN 37831-0062

www.osti.gov

Phone: (865) 576-8401

Fax: (865) 576-5728

Email: reports@osti.gov

\section{Disclaimer}

This report was prepared as an account of work sponsored by an agency of the United States Government. Neither the United States Government nor any agency thereof, nor UChicago Argonne, LLC, nor any of their employees or officers, makes any warranty, express or implied, or assumes any legal liability or responsibility for the accuracy, completeness, or usefulness of any information, apparatus, product, or process disclosed, or represents that its use would not infringe privately owned rights. Reference herein to any specific commercial product, process, or service by trade name, trademark, manufacturer, or otherwise, does not necessarily constitute or imply its endorsement, recommendation, or favoring by the United States Government or any agency thereof. The views and opinions of document authors expressed herein do not necessarily state or reflect those of the United States Government or any agency thereof, Argonne National Laboratory, or UChicago Argonne, LLC. 
ANL/ESD-21/3

\section{Lithium-Ion Battery Supply Chain for E-Drive Vehicles in the United States: 2010-2020}

by

Yan Zhou, David Gohlke, Luke Rush, Jarod Kelly, and Qiang Dai Energy Systems Division, Argonne National Laboratory

March 2021 


\section{CONTENTS}

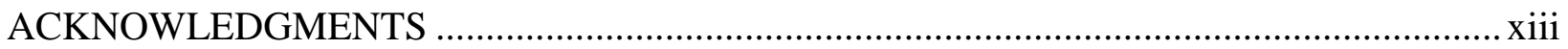

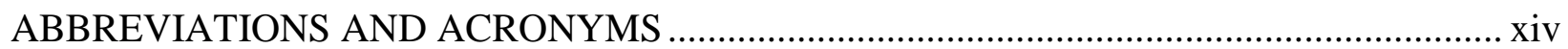

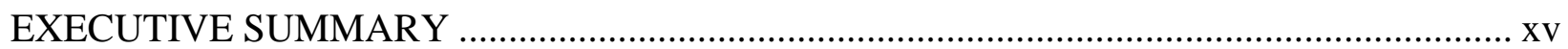

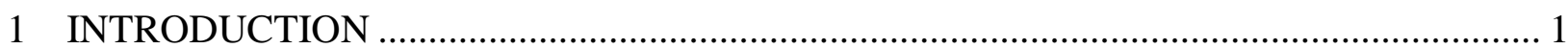

2 PEV BATTERY AND SUPPLIER DEVELOPMENT …............................................... 3

3 BATTERY MANUFACTURING LOCATIONS AND DATA ASSUMPTIONS ................. 9

4 HISTORICAL TRENDS: PEV BATTERY PACK AND CELL PRODUCTION ................ 10

5 LITHIUM-ION BATTERIES IN HEVs................................................................... 13

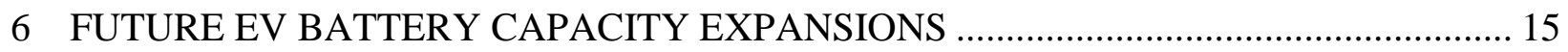

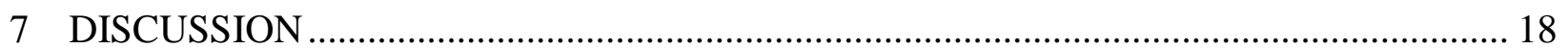

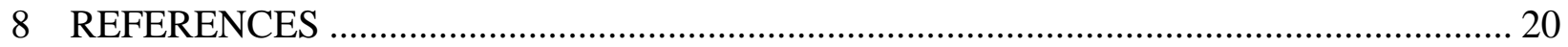

APPENDIX A: LI-ION BATTERY CELL AND PACK FLOW DIAGRAMS FOR PEVs ....... 23

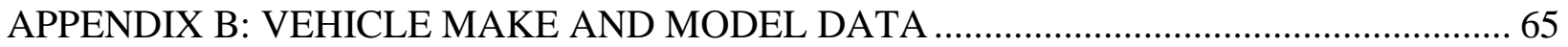

\section{FIGURES}

ES-1 Annual battery cell and battery pack capacity supplied to the U.S. PEV market by production country ................................................................................

ES-2 Total capacity (MWh) of Li-ion batteries supplied to the U.S. PEV market by production location, 2010-2020. xvi

2-1 Annual PEV sales by battery cell manufacturer. "Others" includes Li-tec, GS Yuasa, Toshiba, Blue Energy, and A123. 4

2-2 Annual PEV battery capacity (GWh) by battery cell manufacturer. "Others" includes Li-tec, GS Yuasa, Toshiba, Blue Energy, and A123.

2-3 Annual PEV sales by battery pack manufacturer. "Others" includes Accumotive, GS Yuasa, Primearth EV Energy, Toshiba, Blue Energy, A123, Jaguar, and Draexlmaier.

2-4 Annual PEV battery capacity (GWh) by battery pack manufacturer. "Others" includes Accumotive, GS Yuasa, Primearth EV Energy, Toshiba, Blue Energy, A123, Jaguar, and Draexlmaier. 5

2-5 Annual PEV battery cell capacity (GWh) by production country ................................ 6

2-6 Annual PEV battery pack capacity (GWh) by production country ............................... 6 


\section{FIGURES (CONT.)}

2-7 Total capacity (MWh) of Li-ion batteries supplied to the U.S. PEV market by manufacturer, 2010-2020. "Others" for battery cells includes Li-tec, GS Yuasa, Toshiba, Blue Energy, and A123. "Others" for battery packs includes Accumotive, GS Yuasa, Primearth EV Energy, Toshiba, Blue Energy, A123, Jaguar, and Draexlmaier. "Others" for vehicle makes includes Smart, Mitsubishi, Fiat, Cadillac, Mercedes, Volkswagen, Volvo, Hyundai, Chrysler, MINI, Jaguar, Subaru, Land Rover, Lincoln, Polestar, and Jeep.

2-8 Number of Li-ion battery packs (or vehicles) supplied to the U.S. PEV market by battery manufacturer, 2010-2020. "Others" for battery cell includes Li-tec, GS Yuasa, Toshiba, Blue Energy, and A123. "Others” for battery pack includes Accumotive, GS Yuasa, Primearth EV Energy, Toshiba, Blue Energy, A123, Jaguar, and Draexlmaier. "Others" for vehicle makes includes Smart, Mitsubishi, Fiat, Cadillac, Mercedes, Volkswagen, Volvo, Hyundai, Chrysler, MINI, Jaguar, Subaru, Land Rover, Lincoln, Polestar, and Jeep

4-1 Total capacity (MWh) of Li-ion batteries supplied to the U.S. PEV market by production location, 2010-2020. (From left to right: battery cell production location, battery pack production location, vehicle assembly location, and vehicles sold in the U.S.)

4-2 Number of Li-ion battery packs (or vehicles) supplied to the U.S. PEV market by production location, 2010-2020. (From left to right: battery cell production location, battery pack production location, vehicle assembly location, and vehicles sold in the U.S.)

5-1 Share of Li-ion batteries in HEVs sold in the U.S., 2008-2020.

6-1 Future global Li-ion battery demand and production capacity, 2020-2030. BMO: Bank of Montreal, BNEF: Bloomberg New Energy Finance, CES: Circular Energy Storage, LU: Leiden University, ANL: Argonne National Laboratory, WEF: World Economic Forum. Note: Roland Berger provided 2019 estimates instead of 2020, hence the omitted data points for those sources in 2020 .

7-1 Share of total annual Li-ion battery capacity by long- and short-range BEV (above/below 150 miles), long- and short- range of PHEVs (above/below 20 miles), and HEVs in the U.S., 2010-2020.

A-1 2011 Total capacity (MWh) of Li-ion batteries supplied to the U.S. PEV market by manufacturer. "Others" for battery cell includes Li-tec and GS Yuasa; "Others" for battery pack includes Accumotive and GS Yuasa. "Others" for vehicle makes includes Smart and Mitsubishi. 


\section{FIGURES (CONT.)}

A-2 2012 Total capacity (MWh) of Li-ion batteries supplied to the U.S. PEV market by manufacturer. "Others" for battery cell includes Li-tec, GS Yuasa, and Toshiba; "Others" for battery pack includes Accumotive, GS Yuasa, Primearth EV Energy, and Toshiba. "Others" for vehicle makes includes Smart and Mitsubishi.

A-3 2013 Total capacity (MWh) of Li-ion batteries supplied to the U.S. PEV market by manufacturer. "Others" for battery cell includes Li-tec, GS Yuasa, Toshiba, Blue Energy, and A123; "Others" for battery pack includes Accumotive, GS Yuasa, Primearth EV Energy, Toshiba, Blue Energy, and A123. "Others" for vehicle makes includes Smart, Mitsubishi, Fiat, and Cadillac.

A-4 2014 Total capacity (MWh) of Li-ion batteries supplied to the U.S. PEV market by manufacturer. "Others" for battery cell includes Li-tec, GS Yuasa, Toshiba, Blue Energy, and A123; "Others" for battery pack includes Accumotive, GS Yuasa, Primearth EV Energy, Toshiba, Blue Energy, A123 and Sanyo. "Others" for vehicle makes includes Smart, Mitsubishi, Fiat, Cadillac, Mercedes, and Volkswagen.

A-5 2015 Total capacity (MWh) of Li-ion batteries supplied to the U.S. PEV market by manufacturer. "Others" for battery cell includes Li-tec, GS Yuasa, Toshiba, and Blue Energy; "Others" for battery pack includes Accumotive, GS Yuasa, Primearth EV Energy, Toshiba, Blue Energy, and Sanyo. "Others" for vehicle makes includes Smart, Mitsubishi, Fiat, Cadillac, Mercedes, Volkswagen, and Volvo.

A-6 2016 Total capacity (MWh) of Li-ion batteries supplied to the U.S. PEV market by manufacturer. "Others" for battery pack includes Accumotive, GS Yuasa, Primearth EV Energy, and Sanyo. "Others" for vehicle makes includes Smart, Mitsubishi, Fiat, Cadillac, Mercedes, Volkswagen, and Volvo.

A-7 2017 Total capacity (MWh) of Li-ion batteries supplied to the U.S. PEV market by manufacturer. "Others" for battery pack includes Accumotive and GS Yuasa. "Others" for vehicle makes includes Smart, Mitsubishi, Fiat, Cadillac, Mercedes, Volkswagen, Volvo, Chrysler, and MINI.

A-8 2018 Total capacity (MWh) of Li-ion batteries supplied to the U.S. PEV market by manufacturer. "Others" for battery pack includes Accumotive, GS Yuasa, and Jaguar. "Others" for vehicle makes includes Smart, Mitsubishi, Fiat, Cadillac, Mercedes, Volkswagen, Volvo, Chrysler, MINI, and Jaguar.

A-9 2019 Total capacity (MWh) of Li-ion batteries supplied to the U.S. PEV market by manufacturer. "Others" for battery pack includes Accumotive, GS Yuasa, Jaguar, and Draexlmaier. "Others" for vehicle makes includes Smart, Mitsubishi, Fiat, Cadillac, Mercedes, Volkswagen, Volvo, Chrysler, MINI, Jaguar, Subaru, Land Rover, and Lincoln..... 


\section{FIGURES (CONT.)}

A-10 2020 Total capacity (MWh) of Li-ion batteries supplied to the U.S. PEV market by manufacturer. "Others" for battery pack includes Accumotive, GS Yuasa, Jaguar, and Draexlmaier. "Others" for vehicle makes includes Mitsubishi, Fiat, Cadillac, Mercedes, Volkswagen, Volvo, Chrysler, MINI, Jaguar, Subaru, Land Rover, Lincoln, Polestar, and Jeep.

A-11 2011 Number of battery packs (or vehicles) supplied to the U.S. PEV market by manufacturer. "Others" for battery cell includes Li-tec and GS Yuasa; "Others" for battery pack includes Accumotive and GS Yuasa. "Others" for vehicle makes includes Smart and Mitsubishi.

A-12 2012 Number of battery packs (or vehicles) supplied to the U.S. PEV market by manufacturer. "Others" for battery cell includes Li-tec, GS Yuasa, and Toshiba; "Others" for battery pack includes Accumotive, GS Yuasa, Primearth EV Energy, and Toshiba. "Others" for vehicle makes includes Smart and Mitsubishi.

A-13 2013 Number of battery packs (or vehicles) supplied to the U.S. PEV market by manufacturer. "Others" for battery cell includes Li-tec, GS Yuasa, Toshiba, Blue Energy, and A123; "Others" for battery pack includes Accumotive, GS Yuasa, Primearth EV Energy, Toshiba, Blue Energy, and A123. "Others" for vehicle makes includes Smart, Mitsubishi, Fiat, and Cadillac.

A-14 2014 Number of battery packs (or vehicles) supplied to the U.S. PEV market by manufacturer. "Others" for battery cell includes Li-tec, GS Yuasa, Toshiba, Blue Energy, and A123; "Others" for battery pack includes Accumotive, GS Yuasa, Primearth EV Energy, Toshiba, Blue Energy, A123 and Sanyo. "Others" for vehicle makes includes Smart, Mitsubishi, Fiat, Cadillac, Mercedes, and Volkswagen.

A-15 2015 Number of battery packs (or vehicles) supplied to the U.S. PEV market by manufacturer. "Others" for battery cell includes Li-tec, GS Yuasa, Toshiba, and Blue Energy; "Others" for battery pack includes Accumotive, GS Yuasa, Primearth EV Energy, Toshiba, Blue Energy, and Sanyo. "Others” for vehicle makes includes Smart, Mitsubishi, Fiat, Cadillac, Mercedes, Volkswagen, and Volvo

A-16 2016 Number of battery packs (or vehicles) supplied to the U.S. PEV market by manufacturer. "Others" for battery pack includes Accumotive, GS Yuasa, Primearth EV Energy, and Sanyo. "Others" for vehicle makes includes Smart, Mitsubishi, Fiat, Cadillac, Mercedes, Volkswagen, and Volvo.....

A-17 2017 Number of battery packs (or vehicles) supplied to the U.S. PEV market by manufacturer. "Others" for battery pack includes Accumotive and GS Yuasa. "Others" for vehicle makes includes Smart, Mitsubishi, Fiat, Cadillac, Mercedes, Volkswagen, Volvo, Chrysler, and MINI. 


\section{FIGURES (CONT.)}

A-18 2018 Number of battery packs (or vehicles) supplied to the U.S. PEV market by manufacturer. "Others" for battery pack includes Accumotive, GS Yuasa, and Jaguar. "Others" for vehicle makes includes Smart, Mitsubishi, Fiat, Cadillac, Mercedes, Volkswagen, Volvo, Chrysler, MINI, and Jaguar.

A-19 2019 Number of battery packs (or vehicles) supplied to the U.S. PEV market by manufacturer. "Others" for battery pack includes Accumotive, GS Yuasa, Jaguar, and Draexlmaier. "Others" for vehicle makes includes Smart, Mitsubishi, Fiat, Cadillac, Mercedes, Volkswagen, Volvo, Chrysler, MINI, Jaguar, Subaru, Land Rover, and Lincoln.

A-20 2020 Number of battery packs (or vehicles) supplied to the U.S. PEV market by manufacturer. "Others" for battery pack includes Accumotive, GS Yuasa, Jaguar, and Draexlmaier. "Others" for vehicle makes includes Mitsubishi, Fiat, Cadillac, Mercedes, Volkswagen, Volvo, Chrysler, MINI, Jaguar, Subaru, Land Rover, Lincoln, Polestar, and Jeep. 35

A-21 2011 Total capacity (MWh) of Li-ion batteries supplied to the U.S. PEV market by production location.

A-22 2012 Total capacity (MWh) of Li-ion batteries supplied to the U.S. PEV market by production location.

A-23 2013 Total capacity (MWh) of Li-ion batteries supplied to the U.S. PEV market by production location.

A-24 2014 Total capacity (MWh) of Li-ion batteries supplied to the U.S. PEV market by production location.

A-25 2015 Total capacity (MWh) of Li-ion batteries supplied to the U.S. PEV market by production location.

A-26 2016 Total capacity (MWh) of Li-ion batteries supplied to the U.S. PEV market by production location. "Others" for battery pack includes Japan, Poland, and Hungary; "Others" for vehicle assembly includes France, Japan, and Sweden.

A-27 2017 Total capacity (MWh) of Li-ion batteries supplied to the U.S. PEV market by production location." Others" for battery pack includes Poland and China; "Others" for vehicle assembly includes France, Sweden, Canada, China, Austria, and Netherlands. 38

A-28 2018 Total capacity (MWh) of Li-ion batteries supplied to the U.S. PEV market by production location. "Others" for battery cell includes Poland and China; "Others" for battery pack includes Poland and China; "Others" for vehicle assembly includes France, Sweden, China, and Netherlands 


\section{FIGURES (CONT.)}

A-29 2019 Total capacity (MWh) of Li-ion batteries supplied to the U.S. PEV market by production location. "Others" for battery cell includes China and Hungary; "Others" for battery pack includes China and U.K.; "Others" for vehicle assembly includes France, Sweden, China, Netherlands, and United Kingdom.

A-30 2020 Total capacity (MWh) of Li-ion batteries supplied to the U.S. PEV market by production location. "Others" for battery cell includes China and Hungary; "Others" for battery pack includes Hungary, China, and United Kingdom; "Others" for vehicle assembly includes Sweden, China, Netherlands, Mexico, Slovakia, Canada, and United Kingdom.

A-31 2011 Number of battery packs (or vehicles) supplied to the U.S. PEV market by production location.

A-32 2012 Number of battery packs (or vehicles) supplied to the U.S. PEV market by production location.

A-33 2013 Number of battery packs (or vehicles) supplied to the U.S. PEV market by production location.

A-34 2014 Number of battery packs (or vehicles) supplied to the U.S. PEV market by production location.

A-35 2015 Number of battery packs (or vehicles) supplied to the U.S. PEV market by production location.

A-36 2016 Number of battery packs (or vehicles) supplied to the U.S. PEV market by production location. "Others" for battery pack includes Japan, Poland, and Hungary; "Others" for vehicle assembly includes France, Japan, and Sweden.

A-37 2017 Number of battery packs (or vehicles) supplied to the U.S. PEV market by production location. "Others" for battery cell includes Poland and China; "Others" for battery pack includes S. Korea, Poland and China; "Others" for vehicle assembly includes France, S. Korea, Sweden, Canada, China, Austria, and Netherlands.

A-38 2018 Number of battery packs (or vehicles) supplied to the U.S. PEV market by production location. "Others" for battery cell includes China and Hungary; "Others" for battery pack includes Poland, Hungary, S. Korea, and China; "Others" for vehicle assembly includes France, S. Korea, Sweden, China, and Netherlands.

A-39 2019 Number of battery packs (or vehicles) supplied to the U.S. PEV market by production location. "Others" for battery cell includes China and Hungary; "Others" for battery pack includes Poland, China, Belgium, and United Kingdom; "Others" for vehicle assembly includes France, Sweden, China, Netherlands, and United Kingdom. 


\section{FIGURES (CONT.)}

A-40 2020 Number of battery packs (or vehicles) supplied to the U.S. PEV market by production location. "Others" for battery cell includes Hungary and China; "Others" for battery pack includes Hungary, China, and United Kingdom;

"Others" for vehicle assembly includes Sweden, China, Netherlands, Mexico, Slovakia, Canada, and United Kingdom.....

A-41 2011 Total capacity (MWh) of Li-ion batteries supplied to the U.S. BEV

market by production location.

A-42 2012 Total capacity (MWh) of Li-ion batteries supplied to the U.S. BEV market by production location.

A-43 2013 Total capacity (MWh) of Li-ion batteries supplied to the U.S. BEV market by production location.

A-44 2014 Total capacity (MWh) of Li-ion batteries supplied to the U.S. BEV market by production location.

A-45 2015 Total capacity (MWh) of Li-ion batteries supplied to the U.S. BEV market by production location. 48

A-46 2016 Total capacity (MWh) of Li-ion batteries supplied to the U.S. BEV market by production location. 48

A-47 2017 Total capacity (MWh) of Li-ion batteries supplied to the U.S. BEV market by production location.

A-48 2018 Total capacity (MWh) of Li-ion batteries supplied to the U.S. BEV market by production location. "Others" for battery pack includes Germany and Japan.

A-49 2019 Total capacity (MWh) of Li-ion batteries supplied to the U.S. BEV market by production location. "Others" for battery pack includes Germany and Japan. "Others" for vehicle assembly includes France, Mexico, and Japan.

A-50 2020 Total capacity (MWh) of Li-ion batteries supplied to the U.S. BEV market by production location. "Others" for battery cell includes Hungary and China. "Others" for battery pack includes Japan and China. "Others" for vehicle assembly includes Mexico, Japan, China, and United Kingdom.

A-51 2011 Number of battery packs (or vehicles) supplied to the U.S. BEV market by production location.

A-52 2012 Number of battery packs (or vehicles) supplied to the U.S. BEV market by production location.

A-53 2013 Number of battery packs (or vehicles) supplied to the U.S. BEV market by production location.

A-54 2014 Number of battery packs (or vehicles) supplied to the U.S. BEV market by production location. 


\section{FIGURES (CONT.)}

A-55 2015 Number of battery packs (or vehicles) supplied to the U.S. BEV market by production location.

A-56 2016 Number of battery packs (or vehicles) supplied to the U.S. BEV market by production location. 52

A-57 2017 Number of battery packs (or vehicles) supplied to the U.S. BEV market by production location. 53

A-58 2018 Number of battery packs (or vehicles) supplied to the U.S. BEV market by production location. "Others" for battery pack includes Poland and Japan. "Others" for vehicle assembly includes Japan and Austria. 53

A-59 2019 Number of battery packs (or vehicles) supplied to the U.S. BEV market by production location. "Others" for battery pack includes Germany and Japan. "Others" for vehicle assembly includes France, Mexico, and Japan.

A-60 2020 Number of battery packs (or vehicles) supplied to the U.S. BEV market by production location. "Others" for battery cell includes Hungary and China. "Others" for battery pack includes Japan and China. "Others" for vehicle assembly includes Mexico, Japan, China, and United Kingdom.

A-61 2011 Total capacity (MWh) of Li-ion batteries supplied to the U.S. PHEV market by production location.

A-62 2012 Total capacity (MWh) of Li-ion batteries supplied to the U.S. PHEV market by production location.

A-63 2013 Total capacity (MWh) of Li-ion batteries supplied to the U.S. PHEV market by production location.

A-64 2014 Total capacity (MWh) of Li-ion batteries supplied to the U.S. PHEV market by production location.

A-65 2015 Total capacity (MWh) of Li-ion batteries supplied to the U.S. PHEV market by production location.

A-66 2016 Total capacity (MWh) of Li-ion batteries supplied to the U.S. PHEV market by production location.

A-67 2017 Total capacity (MWh) of Li-ion batteries supplied to the U.S. PHEV market by production location. "Others" for vehicle assembly includes China and Netherlands.

A-68 2018 Total capacity (MWh) of Li-ion batteries supplied to the U.S. PHEV market by production location. "Others" for battery cell includes Poland and China. "Others" for battery pack includes Poland and China. "Others" for vehicle assembly includes Sweden and China. 


\section{FIGURES (CONT.)}

A-69 2019 Total capacity (MWh) of Li-ion batteries supplied to the U.S. PHEV market by production location. "Others" for battery cell includes Poland and China. "Others" for battery pack includes China, Belgium, and United Kingdom. "Others" for vehicle assembly includes Netherlands, China, Belgium, and United Kingdom.

A-70 2020 Total capacity (MWh) of Li-ion batteries supplied to the U.S. PHEV market by production location. "Others" for battery cell includes Hungary and China. "Others" for battery pack includes Belgium, United Kingdom, and China. "Others" for vehicle assembly includes Netherlands, Belgium, United Kingdom, and China.

A-71 2011 Number of battery packs (or vehicles) supplied to the U.S. PHEV market by production location.

A-72 2012 Number of battery packs (or vehicles) supplied to the U.S. PHEV market by production location.

A-73 2013 Number of battery packs (or vehicles) supplied to the U.S. PHEV market by production location.

A-74 2014 Number of battery packs (or vehicles) supplied to the U.S. PHEV market by production location.

A-75 2015 Number of battery packs (or vehicles) supplied to the U.S. PHEV market by production location.

A-76 2016 Number of battery packs (or vehicles) supplied to the U.S. PHEV market by production location.

A-77 2017 Number of battery packs (or vehicles) supplied to the U.S. PHEV market by production location. "Others" for battery pack includes Poland, S. Korea, Hungary, and China. "Others" for vehicle assembly includes Sweden, S.

Korea, China and Netherlands.

A-78 2018 Number of battery packs (or vehicles) supplied to the U.S. PHEV market by production location. "Others" for battery cell includes Hungary and China. "Others" for battery pack includes Poland, Hungary, and China. "Others" for vehicle assembly includes Sweden, Netherlands, and China.

A-79 2019 Number of battery packs (or vehicles) supplied to the U.S. PHEV market by production location. "Others" for battery cell includes Poland and China. "Others" for battery pack includes China, Belgium, United Kingdom. "Others" for vehicle assembly includes Sweden, Netherlands, China, Belgium, and United Kingdom. 


\section{FIGURES (CONT.)}

A-80 2020 Number of battery packs (or vehicles) supplied to the U.S. PHEV market by production location. "Others" for battery cell includes Hungary and China. "Others" for battery pack includes Hungary, Belgium, United Kingdom, and China. "Others" for vehicle assembly includes Netherlands, Belgium, United Kingdom, and China.

\section{TABLES}

B-1 BEV Battery Cell, Battery Pack Manufacturers and Vehicle Assembly

Locations by Make and Model

B-2 PHEV Battery Cell, Battery Pack Manufacturers and Vehicle Assembly Locations by Make and Model .....

B-3 Li-Ion HEV Battery Cell, Battery Pack Manufacturers and Vehicle Assembly Locations by Make and Model 


\section{ACKNOWLEDGMENTS}

The efforts of all authors of Argonne National Laboratory (under Contract DE-AC0206CH11357) are supported by the Vehicle Technologies Office (VTO), Energy Efficiency and Renewable Energy Office, U.S. Department of Energy. The authors would like to thank David Howell and Jacob Ward of the VTO for the continued support of this project and useful and constructive comments. The authors also thank Stacy Davis and Robert Boundy of Oak Ridge National Laboratory for providing sales data and Linda Gaines, Elanna Neppel and Xinyi Wu of Argonne National Laboratory for their assistance with data collection and analysis. 


\section{ABBREVIATIONS AND ACRONYMS}

BEV battery electric vehicle

EV electric vehicle

FHEV full hybrid vehicle

GM

General Motors

GWh

gigawatt-hour(s)

HEV hybrid electric vehicle

ITC U.S. International Trade Commission

kWh kilowatt-hour(s)

LFP lithium iron phosphate

Li-ion lithium-ion

LMO lithium manganese oxide

MHEV mild hybrid electric vehicle

MWh megawatt-hour(s)

NCA nickel cobalt aluminum oxide

$\mathrm{NiMH} \quad$ nickel metal hydride

NMC

nickel manganese cobalt oxide

OEM original equipment manufacturer

PEV plug-in electric vehicle

PHEV plug-in hybrid electric vehicles

TWh terawatt-hour(s)

VIN vehicle identification number 


\section{EXECUTIVE SUMMARY}

Understanding the battery supply chain is particularly important for the strategic planning and development of a battery recycling infrastructure to secure critical materials supply and enable a circular economy. Argonne has been tracking plug-in electric vehicle (PEV) sales in the United States (U.S.) by make and model since December 2010, when the Chevrolet Volt and Nissan Leaf were first sold in the U.S. Building on detailed monthly sales data, this report summarizes the manufacturing and production locations of lithium-ion (Li-ion, or LIB) battery cells and packs by make and model for PEVs sold in the U.S. from 2010 to 2020. It also summarizes the annual and cumulative Li-ion battery capacity installed in hybrid electric vehicles (HEVs) sold in the U.S. Overall, there are about 20 different battery cell and pack manufacturers, which are currently supplying about 20 gigawatt-hours $(\mathrm{GWh})$ of batteries annually for the U.S. PEV market. Panasonic and LG Chem are the largest cell suppliers to the U.S. market. Beyond the U.S, South Korea and Japan are major countries supplying PEV batteries to the U.S. market (Figure ES-1).

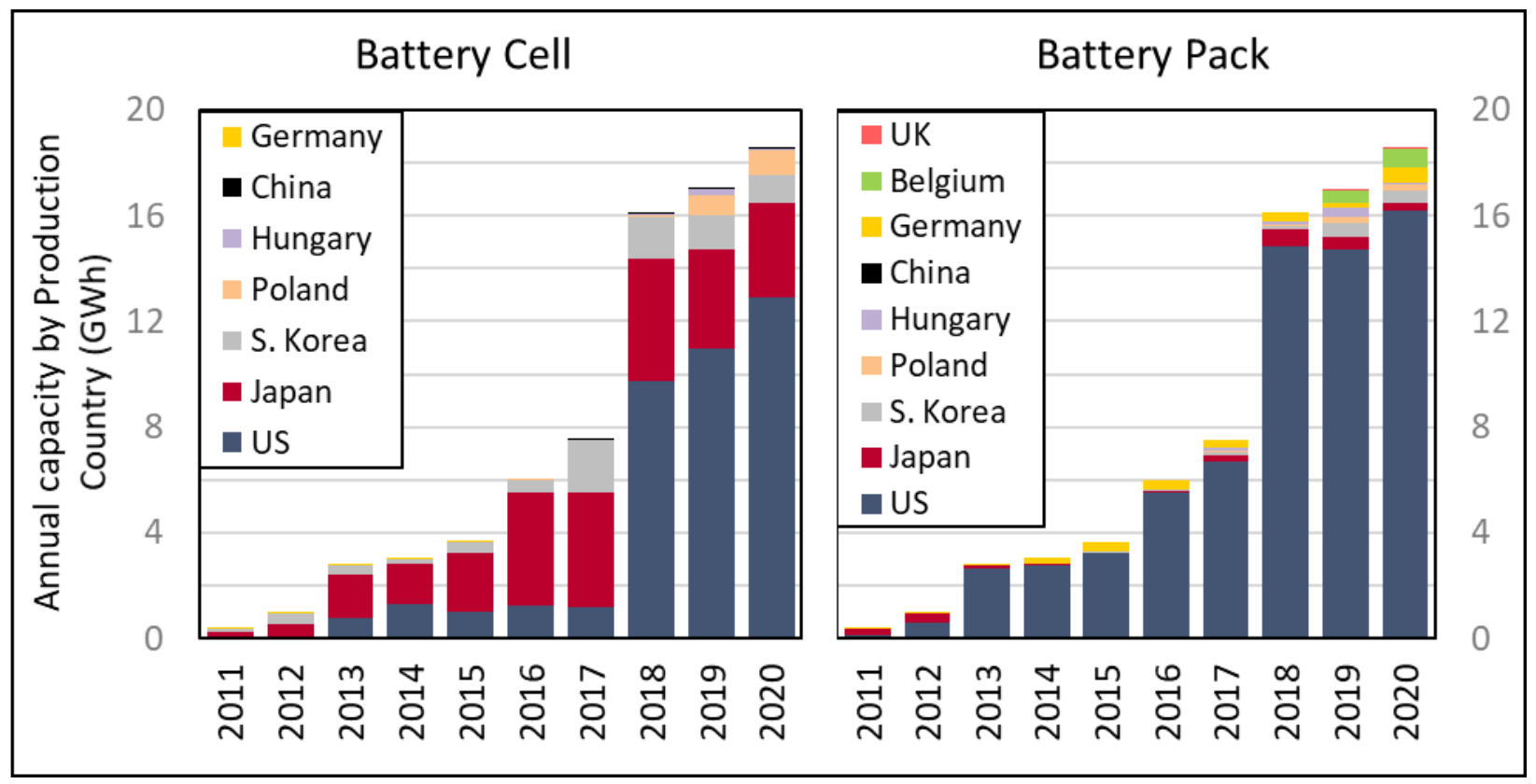

FIGURE ES-1 Annual battery cell and battery pack capacity supplied to the U.S. PEV market by production country

The batteries used in PEVs sold in the U.S. have been largely domestically sourced. In terms of total battery capacity since 2010 , over half of all cells have been produced in the U.S., as have nearly $90 \%$ of all battery packs. This trend toward domestic production has grown over time, with $70 \%$ of battery cells and $87 \%$ of battery packs produced in the U.S. in 2020 . Most of this production is for battery electric vehicles (BEVs) rather than plug-in hybrid vehicles (PHEVs), because of the larger capacity intrinsic to BEVs as well as the greater diversity of manufacturers of PHEVs. However, the large share of domestic production is due to a single player, Tesla/Panasonic. 
This report uses Sankey diagrams to show evolving trends of the supply chain for the production locations and original equipment manufacturers (OEMs) of battery cell, battery pack, and vehicle assembly from 2010 to 2020 . The Sankey diagram format makes it easy to track the flow of production from one location or OEM to another over several steps of the supply chain. Figure ES-2 (from left to right) shows total Li-ion battery capacity (in MWh) supplied to the U.S. PEV market by production location between 2010 and 2020. During this time, a total of approximately $75.9 \mathrm{GWh}(75,900 \mathrm{MWh})$ of battery capacity was installed in PEVs sold in the U.S. Of that total, 65.8 GWh was installed in PEVs that were assembled in the U.S. Of the total battery capacity installed over this period for the U.S. market, $67.4 \mathrm{GWh}$ of battery packs and 39.1 GWh of battery cells were assembled in the U.S. The flow color between each of the nodes is based on the node from which the flow originates.

The share of Li-ion batteries in HEVs has grown since 2010, reaching around half the market for full hybrids and the entire market for mild hybrids in the U.S. The total annual Li-ion battery capacity of HEVs was about $400 \mathrm{MWh}$ in 2020. Among all full hybrids with Li-ion batteries, Panasonic has supplied more than half of the batteries, followed by LG Chem, Blue Energy (GS Yuasa), and Vehicle Energy Japan (Hitachi).

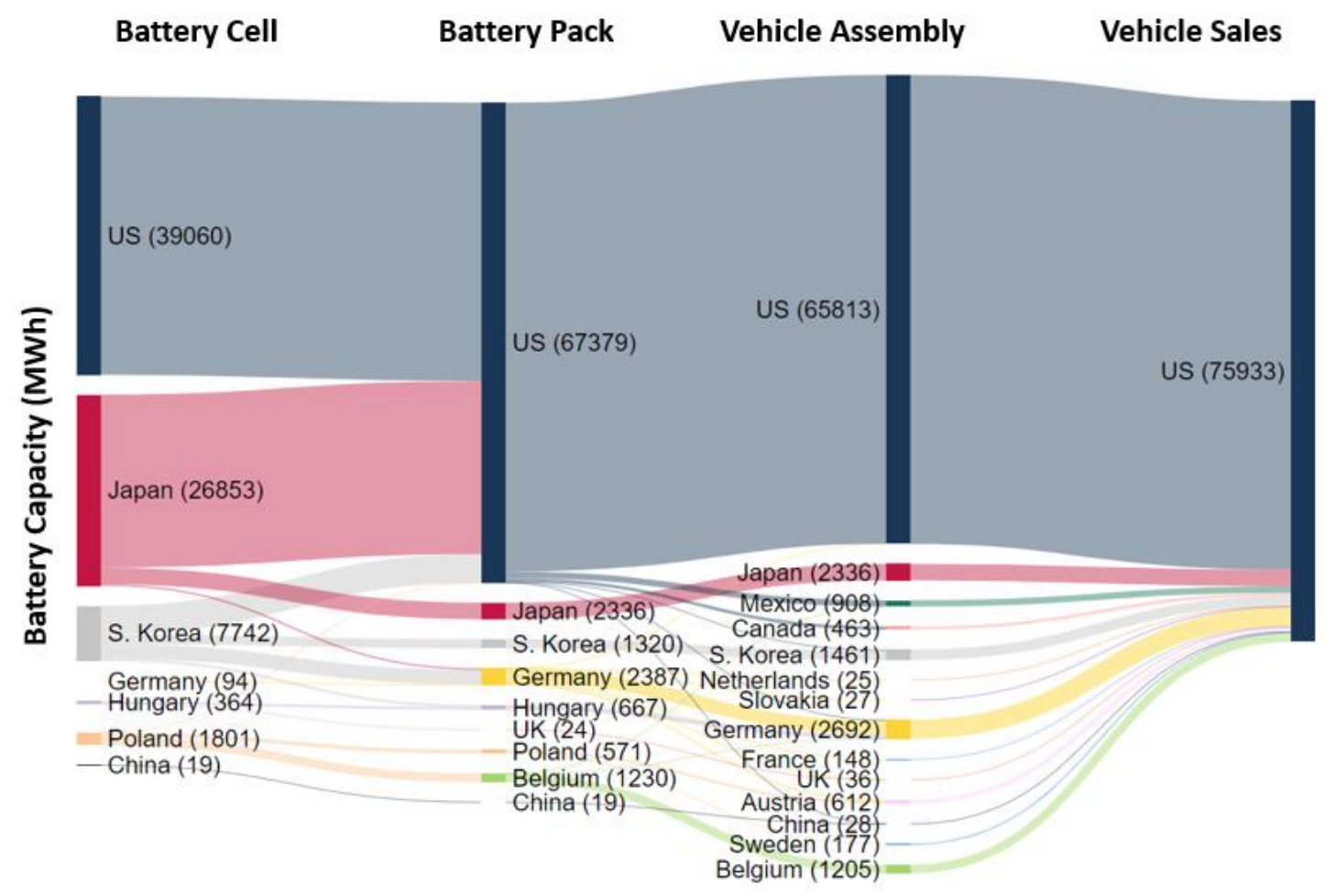

FIGURE ES-2 Total capacity (MWh) of Li-ion batteries supplied to the U.S. PEV market by production location, 2010-2020.

Major Li-ion battery manufacturers have announced plans for, or are already in the process of, constructing new battery cell factories to support rising PEV markets globally. Based on announcements made by major battery supply-chain companies, total U.S. battery production capacity could increase to about $80 \mathrm{GWh}$ per year by 2023. 


\section{INTRODUCTION}

The Chevrolet Volt and Nissan Leaf were introduced to the U.S. market in December 2010. Since then, through the end of 2020, more than 1.71 million plug-in electric vehicles (PEVs) have been sold in the U.S. [1]. PEVs include battery electric vehicles (BEVs) and plug-in hybrid electric vehicles (PHEVs). Annual PEV sales increased from about 18,000 in 2011 to over 330,000 in 2018 but decreased to 307,000 in 2020 as total sales of light-duty vehicles declined. BEVs have accounted for over $60 \%$ of the cumulative PEV sales since 2010.

In 2020, 53 different PEV models were sold in the United States. The sales-weighted electric range of both new and on-road PEVs has increased over the years, which has demanded more battery capacity. The average all-electric range of on-road PHEVs varies between 20 and 35 miles, while the average range of on-road BEVs has grown from approximately 70 miles in 2010 to over 200 miles in 2020 [2]. The sales-weighted all-electric range for BEVs significantly increased in early 2013 and then again in 2018 due to the introduction of Tesla Model S and Model 3, both of which have a range of over 250 miles. Tesla models have a battery capacity ranging from 54 kilowatt-hours $(\mathrm{kWh})$ to $100 \mathrm{kWh}$, which are the highest among all PEV models sold in the U.S. The number of PEV battery suppliers and their annual production capacity in terms of units and megawatt-hours has significantly increased since 2010.

Li-ion batteries that power all PEVs sold in the U.S. have many different material compositions. The most common cathode chemistries for automotive Li-ion batteries are lithium nickel cobalt aluminum oxide (NCA), lithium nickel manganese cobalt oxide (NMC), lithium manganese oxide (LMO), and lithium iron phosphate (LFP). NCA is used in the best-selling BEVs in the United States (Tesla Models S, X, Y, and 3).

The cost of a Li-ion battery pack for PEVs has dropped by $85 \%$ since 2010 [3]. In the same period, the PEV Li-ion battery market has seen consistently high growth rates [4]. With most battery production capacity concentrated in a few companies, these battery suppliers are serving multiple vehicle manufacturers (and global markets) and achieving higher production more quickly.

Battery cell production and battery pack assembly may occur in different countries or be performed by different companies. Worldwide, of the 13 top battery production companies, which supplied $94 \%$ of PEV battery cells in 2017, seven have headquarters in China, three in Japan, and three in South Korea [5]. Currently, Panasonic is the largest cell supplier for the U.S. market, while Korean battery companies are supplying to the largest number of vehicle models. Except for Samsung SDI, the major battery production companies for the U.S. market, such as Panasonic, LG Chem, and SK Innovation, all have factories in the U.S. With new collaborations established with BMW, Volvo, and Honda, automakers that sell PEVs in the U.S., China's battery cell manufacturer CATL (Contemporary Amperex Technology) is building its first overseas plant in Germany and is considering a U.S. factory. 
PEVs are not the only passenger vehicles that use Li-ion batteries, which are also found in hybrid electric vehicles (HEVs) powered solely by gasoline but with an onboard battery to improve fuel efficiency or performance. Historically, nickel metal hydride (NiMH) batteries have been the most common batteries for HEVs, although the share of Li-ion batteries has grown since 2010, reaching around half the market for full hybrids and the entire market for mild hybrids.

Since 2018, PEVs have made up about $2 \%$ of the total light-duty vehicle market in the U.S. Despite a drop in sales due to the COVID-19 pandemic, PEV sales recovered in the U.S. in the third quarter of 2020. Several studies have projected that PEV sales will grow in the near future with the introduction of new models that are equipped with batteries that cost less, perform better, and enable longer driving distances on a single charge $[6,7,8,9]$. Major battery original equipment manufacturers (OEMs) are launching battery production plants that have started production or plan to do so in the next few years. The Wood Mackenzie Energy Storage Service estimated that there are about 285 Li-ion battery GWh-scale factories either in operation or under development across Europe, the Middle East, and Africa with an annual production capacity of $745 \mathrm{GWh}[10]$.

Using monthly sales data for each make and model, this report summarizes Li-ion battery cell and pack production by manufacturer and country. This report also summarizes the industry announcements of future investment plans and battery production targets. The focus of this work is Li-ion batteries used in PEVs and HEVs that were sold in the U.S.

This report has seven sections. The next section, Section 2, discusses major battery manufacturers supplying the U.S. market. Section 3 summarizes battery cell and pack production locations by PEV make and model. Section 4 shows historical trends of PEV battery pack and cell production. Section 5 analyzes Li-ion battery capacity installed in HEVs. Section 6 summarizes EV battery production capacity expansions announced by major suppliers, and Section 7 is the discussion. Appendix A presents battery supply-chain flow charts for each year from 2011 to 2020 for both BEVs and PHEVs, while Appendix B presents the details of each individual vehicle model (PEVs and HEVs) used for calculations. 


\section{PEV BATTERY AND SUPPLIER DEVELOPMENT}

This report summarizes the vehicle manufacturing companies and their battery suppliers for each PEV model from 2010 to 2020. Figures 2-1 to 2-4 show annual PEV sales and the associated PEV battery cell and pack capacity by battery manufacturer. Annual PEV sales increased from a few hundred in 2010 to over 330,000 by 2018 but slightly decreased to 320,000 in 2019. The lower demand due to the COVID-19 pandemic further reduced PEV sales to 307,000 in 2020. However, the battery capacity (in GWh) supplied to the U.S. market increased in both 2019 and 2020, despite the lower total PEV sales, because the average battery capacity per vehicle increased.

The number of companies providing batteries for PEVs sold in the U.S. has increased since 2010. Currently, there are about 20 different battery cell and pack manufacturers, which are supplying about $20 \mathrm{GWh}$ in battery capacity annually for the U.S. market. It is evident that some of the suppliers are serving multiple vehicle manufacturers and have been able to scale up their production capacity more quickly than others.

Panasonic and LG Chem are the largest cell suppliers for the U.S. market. Panasonic supplies battery cells for about 15 vehicle models, including top-selling models such as Tesla Model S, Model X, Model Y, and Model 3. In total, Panasonic supplied battery cells to 70.9\% of vehicles sold in 2020 in the U.S. LG Chem has the second largest share of both battery cells and battery packs for vehicles sold in the U.S., approximately 19\% and 17\%, respectively, in 2020. Of the total battery cell production in the U.S., the Panasonic share, in terms of capacity, is quite large, reaching a high of $88.5 \%$ in 2018 , though falling to $84.9 \%$ in 2020 , due to the large batteries in Tesla models (Model S, X, Y, and 3) and their high number of sales.

This report also summarizes the battery and vehicle manufacturing location for each PEV model from 2010 to 2020. Domestic production continues to be the largest source of battery packs for the U.S. PEV market, and since 2018, has become the largest source of battery cell production. Again, this is primarily driven by the large batteries and high number of sales of the Tesla models. Beyond the U.S, S. Korea and Japan are major battery supply countries supplying PEV batteries to the U.S. markets, as shown in Figures 2-5 and 2-6. 


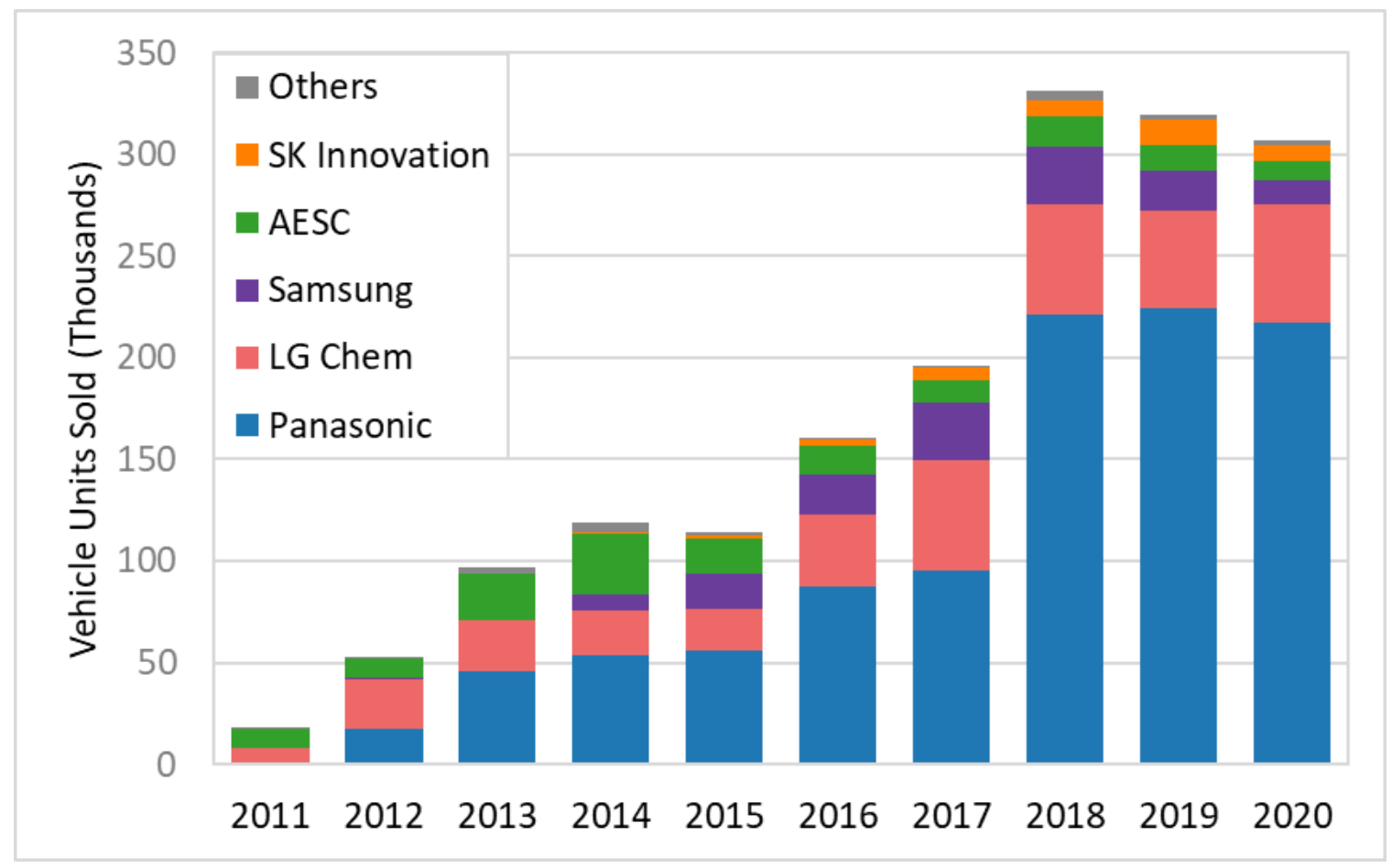

FIGURE 2-1 Annual PEV sales by battery cell manufacturer. "Others" includes Li-tec, GS Yuasa, Toshiba, Blue Energy, and A123.

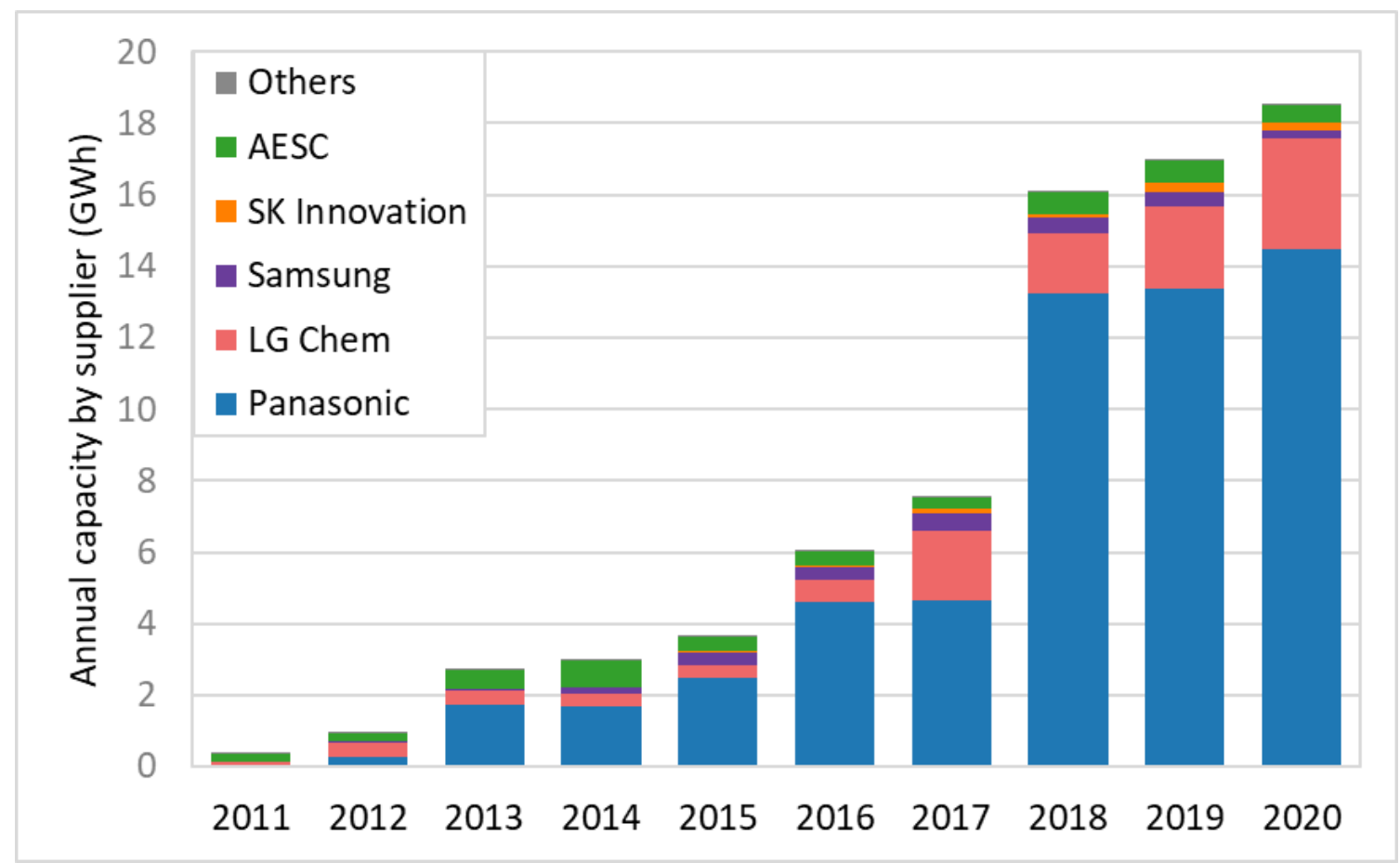

FIGURE 2-2 Annual PEV battery capacity (GWh) by battery cell manufacturer. "Others" includes Li-tec, GS Yuasa, Toshiba, Blue Energy, and A123. 


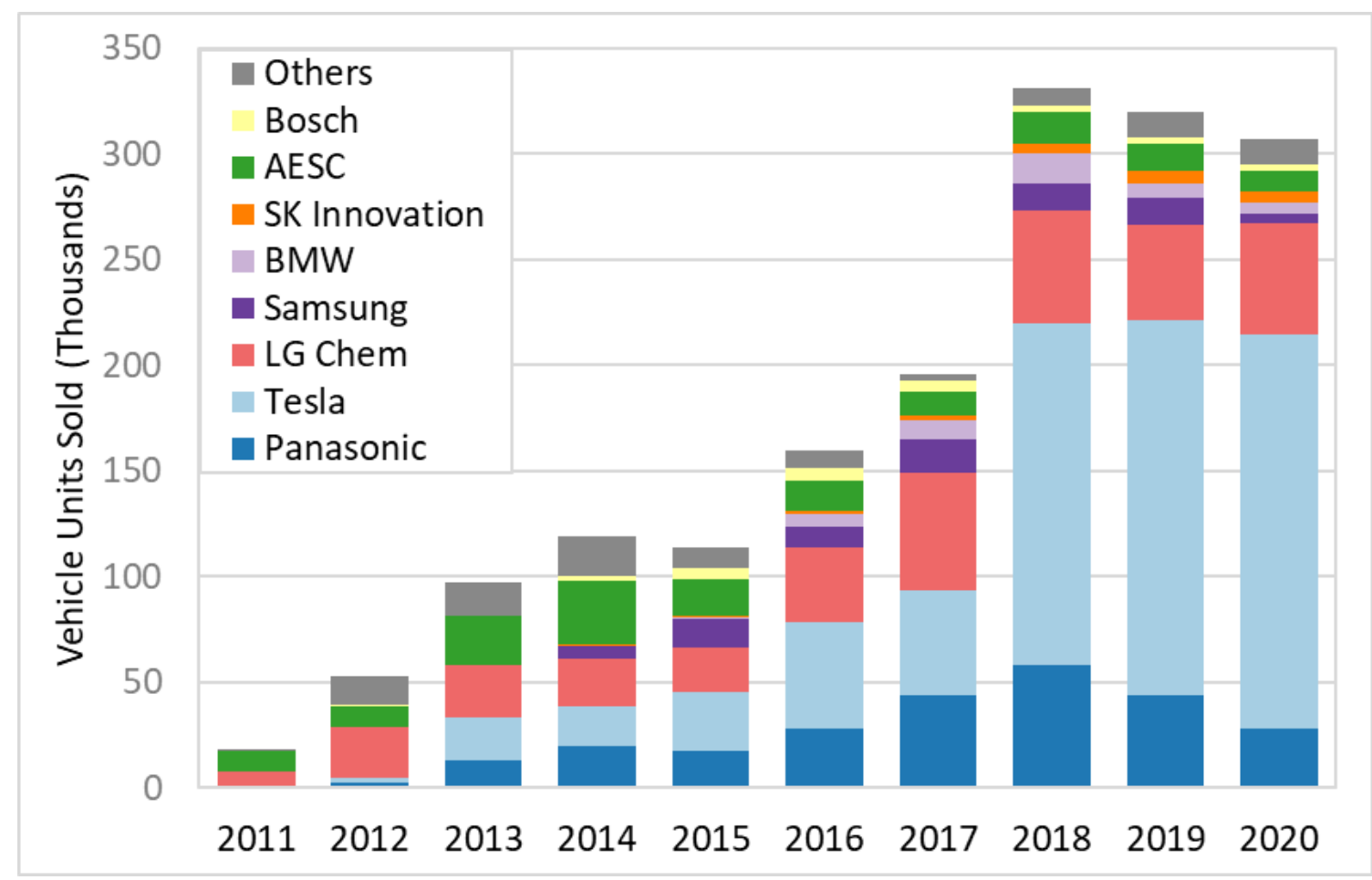

FIGURE 2-3 Annual PEV sales by battery pack manufacturer. "Others" includes Accumotive, GS Yuasa, Primearth EV Energy, Toshiba, Blue Energy, A123, Jaguar, and Draexlmaier.

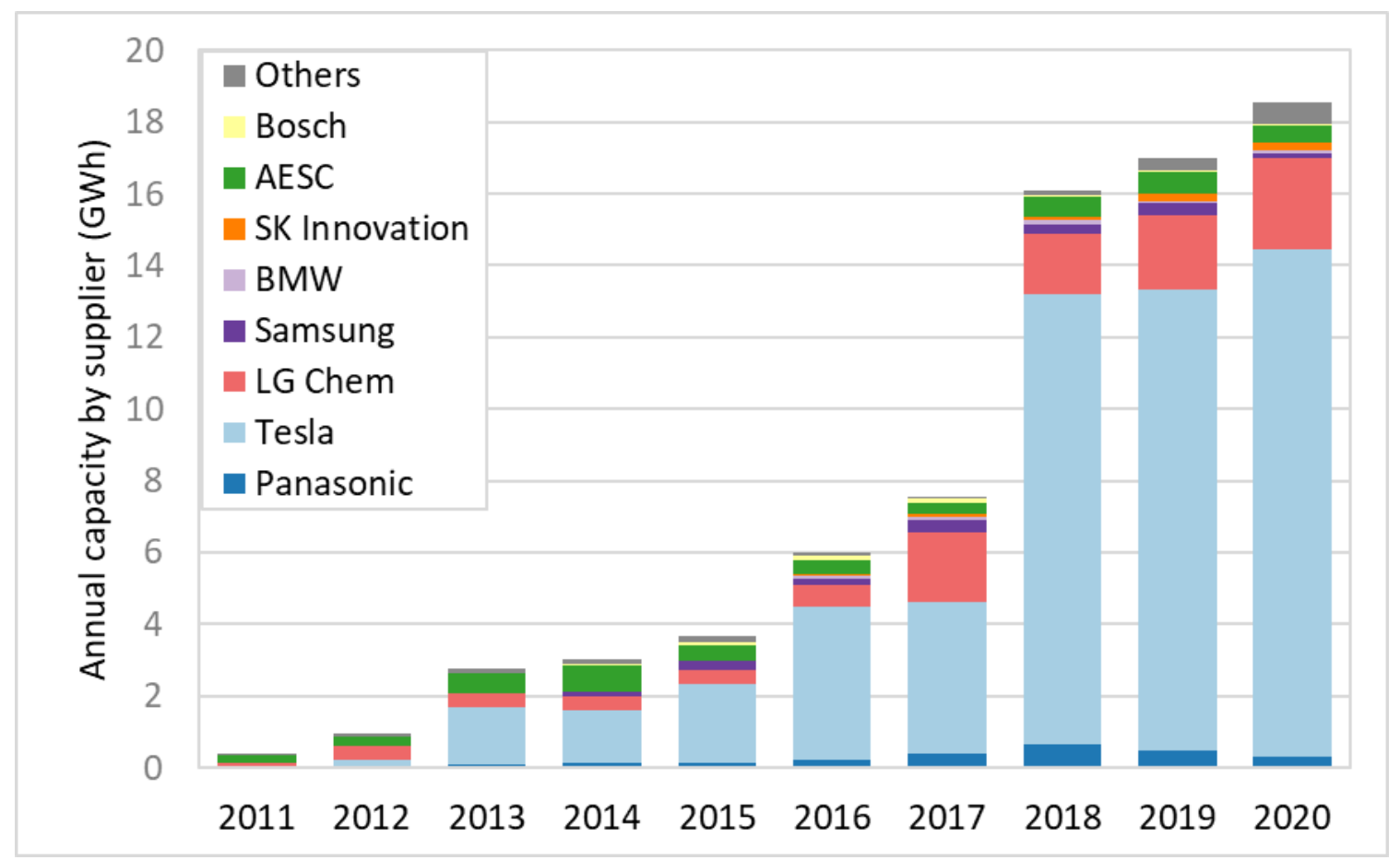

FIGURE 2-4 Annual PEV battery capacity (GWh) by battery pack manufacturer. “Others" includes Accumotive, GS Yuasa, Primearth EV Energy, Toshiba, Blue Energy, A123, Jaguar, and Draexlmaier. 


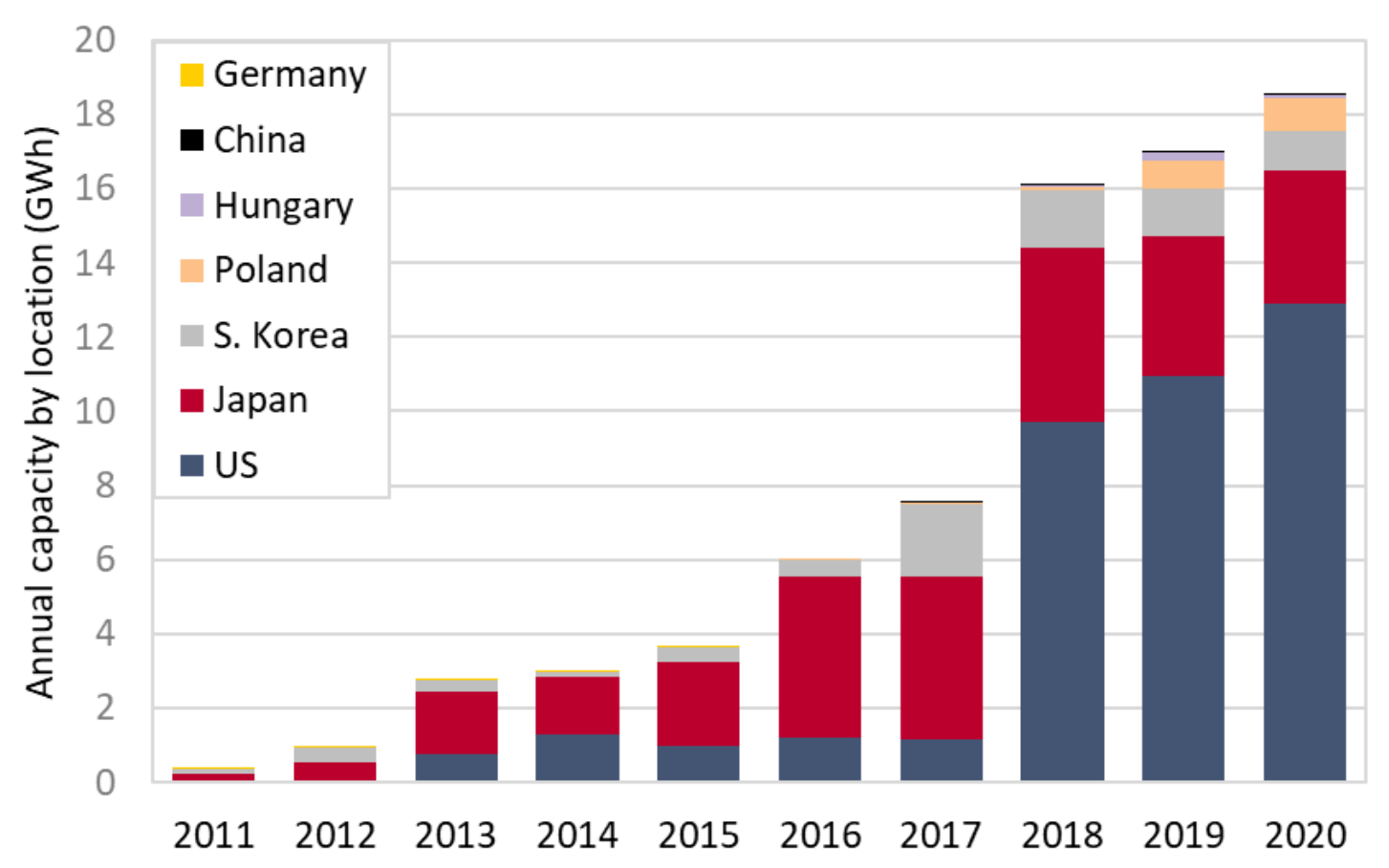

FIGURE 2-5 Annual PEV battery cell capacity (GWh) by production country

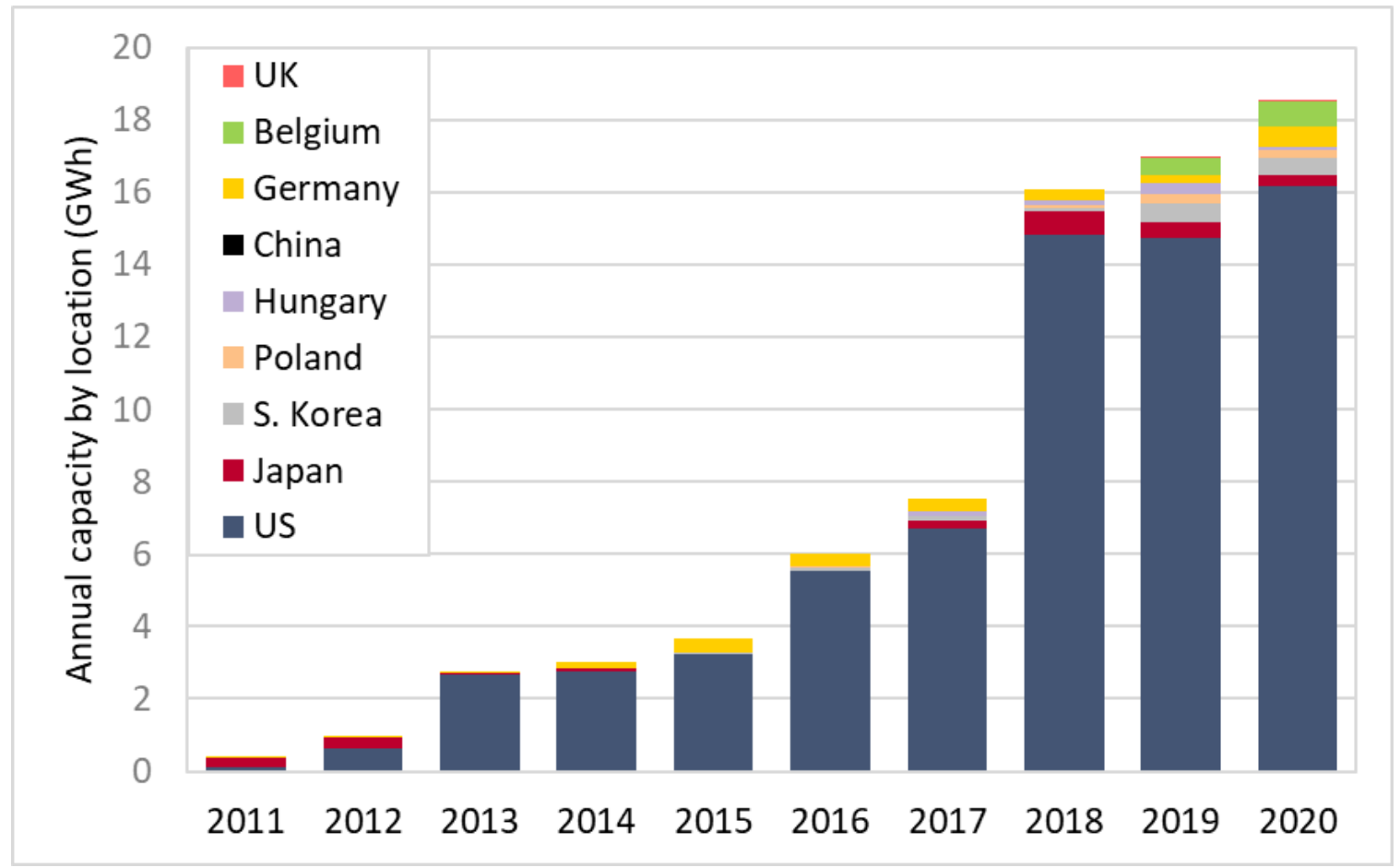

FIGURE 2-6 Annual PEV battery pack capacity (GWh) by production country 
Several battery pack manufacturers also produce battery cells. Panasonic and Tesla both develop batteries at the Gigafactory in Nevada, USA. Panasonic manufactures and supplies the battery cells to Tesla, which then produces their own battery packs at the Gigafactory [11]. Panasonic also assembles PEV battery packs for Honda, Toyota, Ford, and others. LG Chem supplies batteries to GM for the Chevrolet Bolt, and previously supplied batteries for the Chevrolet Volt and other models [12]. AESC (Automotive Energy Supply Corp.) was previously a subsidiary of Nissan, but the majority stake is now owned by Envision, which continues to produce batteries under the AESC brand [13]. Figure 2-7 shows the 2010-2020 cumulative battery capacity, in MWh, and its flow between battery cell suppliers, battery pack producers, and vehicle makes. Figure 2-8 shows the same trend but in number of vehicles sold in the U.S. In total, about 75,933 MWh (76 GWh) of batteries have been supplied and installed in the PEVs sold in the U.S. from 2010 to 2020. Panasonic supplied cells for nearly $60 \%$ of total PEVs sold, and $74 \%$ of the total capacity installed. Similar figures showing the evolving market by year can be found in Appendix A as Figures A-1 to A-20.

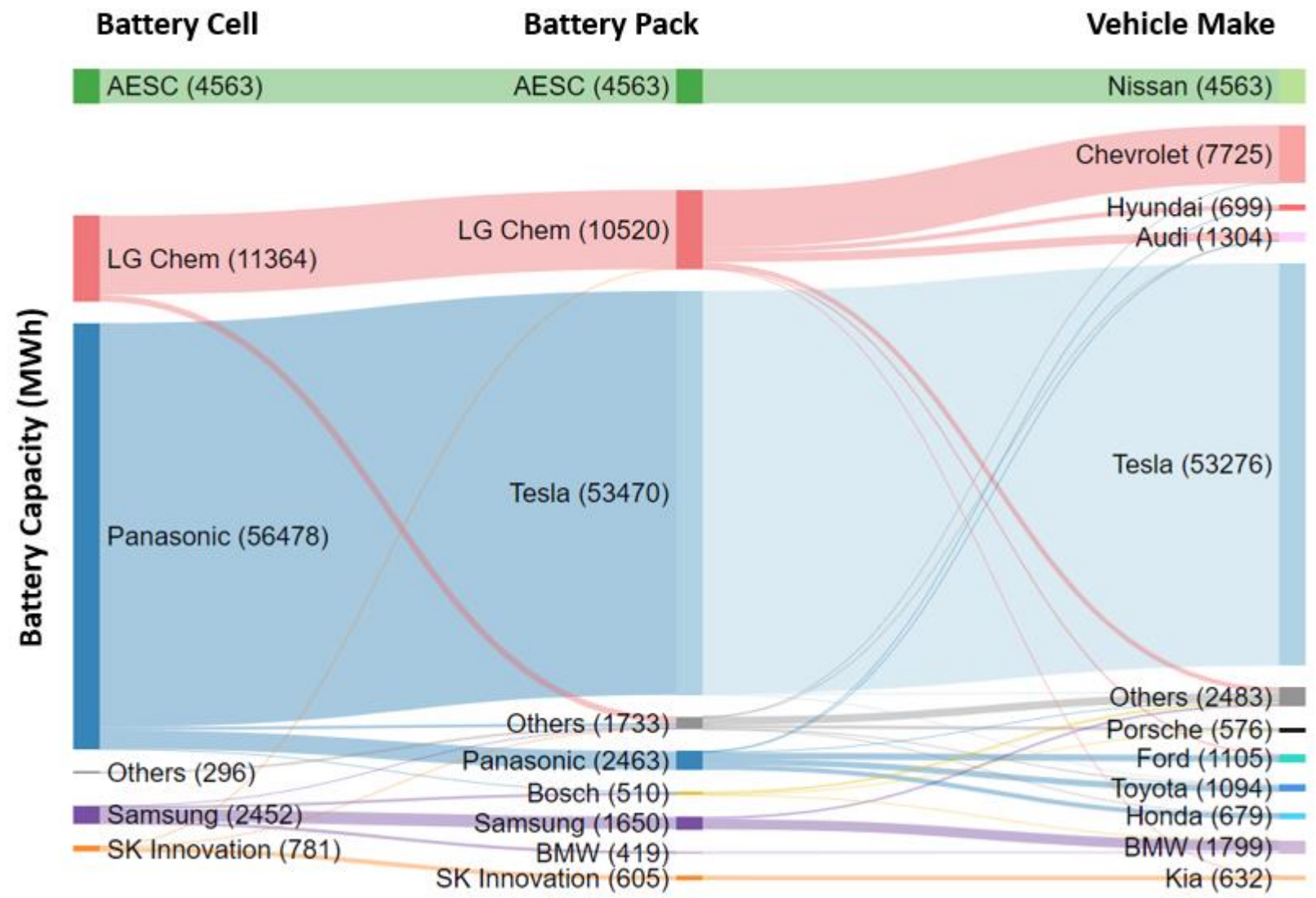

FIGURE 2-7 Total capacity (MWh) of Li-ion batteries supplied to the U.S. PEV market by manufacturer, 2010-2020. "Others" for battery cells includes Li-tec, GS Yuasa, Toshiba, Blue Energy, and A123. "Others” for battery packs includes Accumotive, GS Yuasa, Primearth EV Energy, Toshiba, Blue Energy, A123, Jaguar, and Draexlmaier. "Others" for vehicle makes includes Smart, Mitsubishi, Fiat, Cadillac, Mercedes, Volkswagen, Volvo, Hyundai, Chrysler, MINI, Jaguar, Subaru, Land Rover, Lincoln, Polestar, and Jeep. 


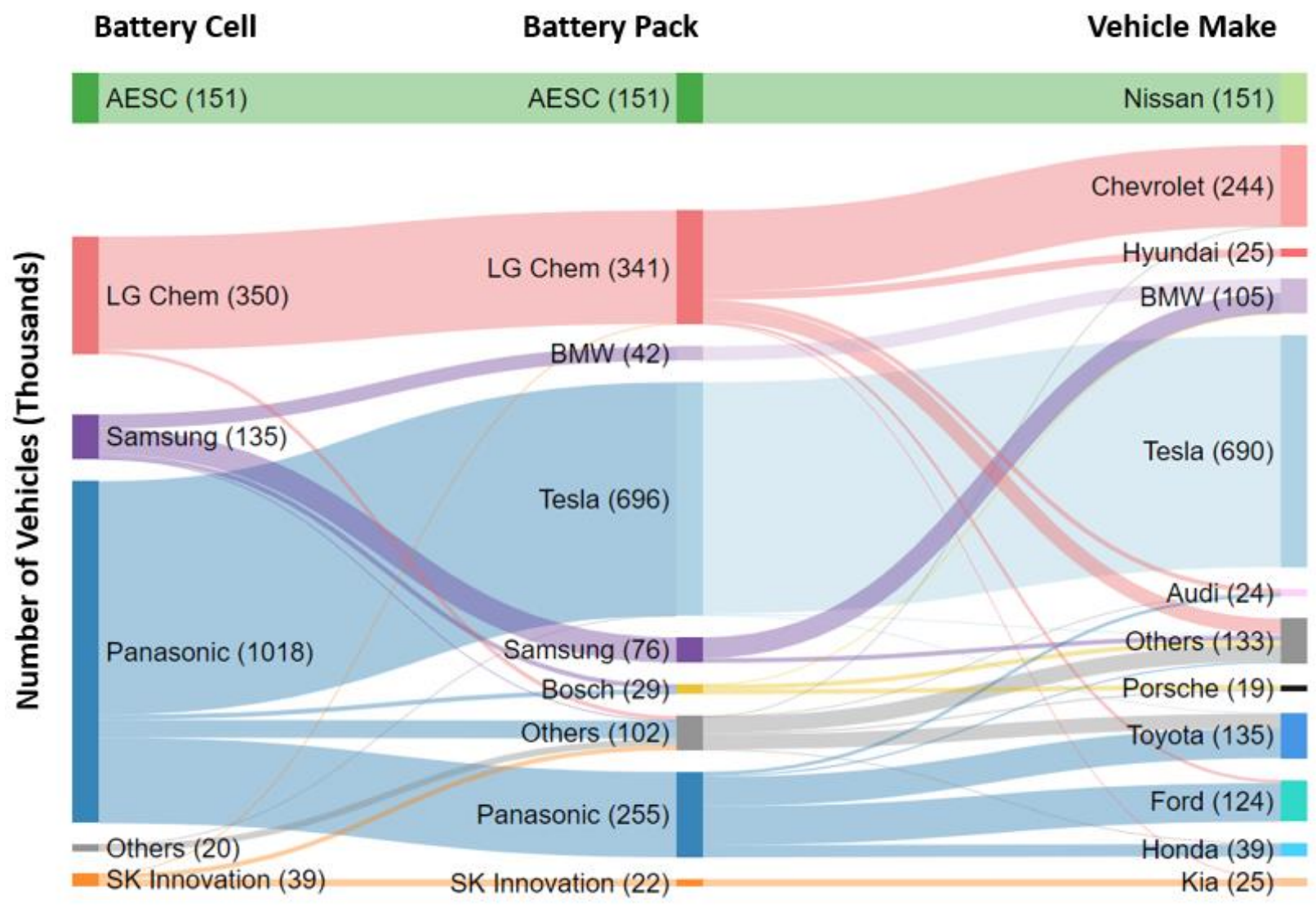

FIGURE 2-8 Number of Li-ion battery packs (or vehicles) supplied to the U.S. PEV market by battery manufacturer, 2010-2020. "Others" for battery cell includes Li-tec, GS Yuasa, Toshiba, Blue Energy, and A123. "Others" for battery pack includes Accumotive, GS Yuasa, Primearth EV Energy, Toshiba, Blue Energy, A123, Jaguar, and Draexlmaier. "Others" for vehicle makes includes Smart, Mitsubishi, Fiat, Cadillac, Mercedes, Volkswagen, Volvo, Hyundai, Chrysler, MINI, Jaguar, Subaru, Land Rover, Lincoln, Polestar, and Jeep. 


\section{BATTERY MANUFACTURING LOCATIONS AND DATA ASSUMPTIONS}

Battery manufacturers are typically multinational corporations; this report distinguishes batteries made in factories in different locations to the extent practicable. The same battery supplier could produce their battery cells and packs in different locations at different times, depending on the production capacity of each factory and business strategies. For example, Panasonic has PEV battery factories in Japan, China, and the U.S., while LG Chem produces PEV batteries in S. Korea, Poland, China, and the U.S. Both SK Innovation and Samsung SDI have factories in S. Korea, Hungary, and China. Tables B-1 and B-2 in Appendix B summarize the battery cell and pack production locations by PEV make and model, along with the estimated corresponding cumulative sales of each model from 2010 to 2020 . The sales data and most of the battery and vehicle assembly location information do not separate by vehicle model year; therefore, in Tables B-1 and B-2, we tracked the changes in production locations and resulting sales for that location by calendar year rather than by vehicle model year, acknowledging that there may be changes in production location throughout a year.

Several models have multiple trim lines which are indistinguishable in sales data, yet carry different battery sizes, such as Tesla models, the Nissan Leaf, and the BMW i3. We estimated the average battery capacity for each model year by decoding the vehicle identification numbers (VINs) from publicly available vehicle registration data. We find that $55 \%$ of Nissan Leafs are equipped with the larger-capacity battery and 69\% of the BMW i3 were PHEV with gasoline-fueled range extenders. For Tesla models, $41 \%$ of Tesla Model S, 54\% of Tesla Model $\mathrm{X}$, and $75 \%$ of Tesla Model 3 contained the largest battery available. Further details are available in a forthcoming report [14].

We researched published reports, white papers, and news articles; all sources used are referenced. However, we made several general assumptions when data were not available. First, sources showed that several of the battery packs have cell production locations different than the battery pack assembly locations, which are often close to the vehicle assembly locations.

Therefore, when information on the battery pack location was not available, we assumed that the packs were assembled in the manufacturing location closest to the vehicle manufacturing location. Secondly, when battery cell or pack locations were disclosed in our sources only for certain years, we assumed the locations did not change for other years when such data were not available. Thirdly, we assumed that the vehicle models from the same manufacturer would use the batteries from the same supplier, thus the same production location, when such information was not available. Finally, if information on the specific production and supply time (e.g., month of the year) when the vehicle OEM switched their battery suppliers was not available, we assumed that all vehicles sold in that year used the batteries from the new battery supplier. If the source indicated that the switch happened in the latter half of the year, we assumed all the vehicles sold in the next year used batteries from the new battery supplier. Also, state locations within the U.S. were our best estimate based on the nearest known factory. Specific modeling assumptions for every make and model of PEV are listed in the notes for Tables B-1 and B-2 in Appendix B. Where several battery suppliers are mentioned in the references, we list only the major supplier. 


\section{HISTORICAL TRENDS: PEV BATTERY PACK AND CELL PRODUCTION}

Based on the information in Appendix B's Tables B-1 and B-2, Figures 4-1 and 4-2 summarize the supply chain from battery cell production to battery pack production to vehicle assembly by country for all PEVs sold in the U.S. from 2010 to 2020. For PEVs sold in the U.S., much of the supply chain is domestically sourced. As seen in Figure 4-1, more than half of the cells (in terms of total capacity) have been produced in the U.S. due to the sales success of Tesla models and their large batteries. Pack assembly and vehicle assembly are both largely centered in the U.S. as well. In terms of the number of vehicles sold, the U.S. share is lower, due largely to pack production in Europe and Asia for PEVs with smaller batteries than those in the U.S.

The market has not remained static since 2010, nor is it identical for PHEVs and BEVs. Figures in Appendix A show the evolving trend in the PEV battery supply chain by year, with Figures A-21 to A-30 showing the total battery capacity, and A-31 to A-40 showing the total number of PEV sales. For a greater degree of detail, similar figures distinguishing PHEVs and BEVs are shown in Figures A-41 through A-80. These Sankey diagrams show the historical trends and highlight the impacts of vehicle manufacturers switching their battery suppliers or battery suppliers changing their production locations.

In 2013, for example, the battery-pack production location for the Nissan Leaf changed from Japan to Tennessee, USA. In 2018, the Tesla Gigafactory in Nevada, USA, started producing Panasonic battery cells for Tesla models sold in the U.S. The share of U.S. battery cell production, in terms of battery capacity, significantly increased from 16\% in 2017 to $60 \%$ in 2018 due to the sales success of the Tesla Model 3. This Tesla model represented a total of $8.5 \mathrm{GWh}$ in battery capacity in 2018, which accounted for 53\% of the PEV battery capacity that year. Due to the very high demand for the Tesla Model 3 with its large battery capacity, PEV sales in 2018 increased by $70 \%$ from 2017, while the total battery capacity increased by about $115 \%$.

Since 2017, Korean battery manufacturers have been supplying battery cells for more than 20 PEV models sold in the U.S. However, the shares of Korean battery production were smaller than Japanese battery production (before 2018) and less than the U.S. (since 2018) due to both the lower number of total sales and the relatively smaller batteries used in those models. 


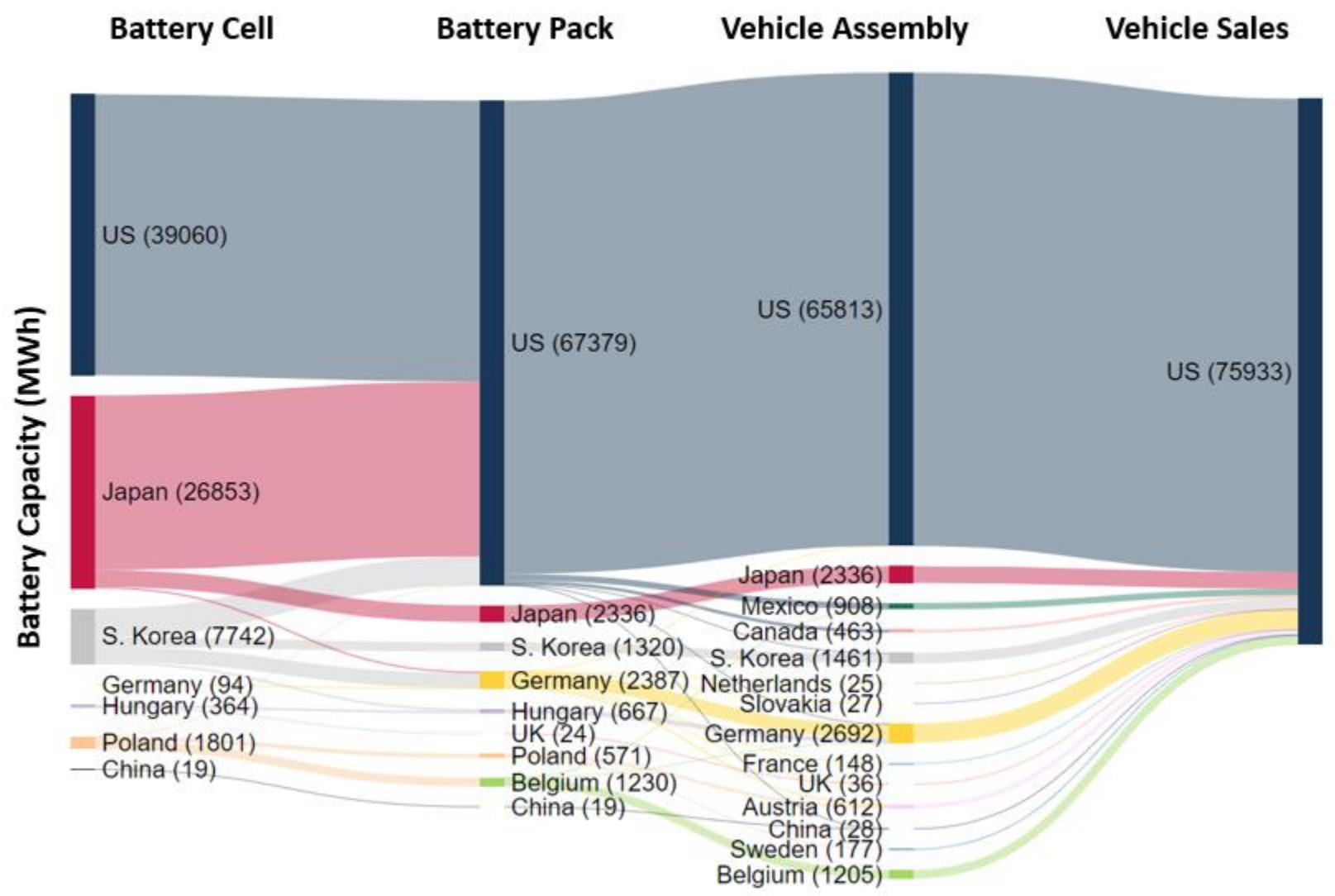

FIGURE 4-1 Total capacity (MWh) of Li-ion batteries supplied to the U.S. PEV market by production location, 2010-2020. (From left to right: battery cell production location, battery pack production location, vehicle assembly location, and vehicles sold in the U.S.) 


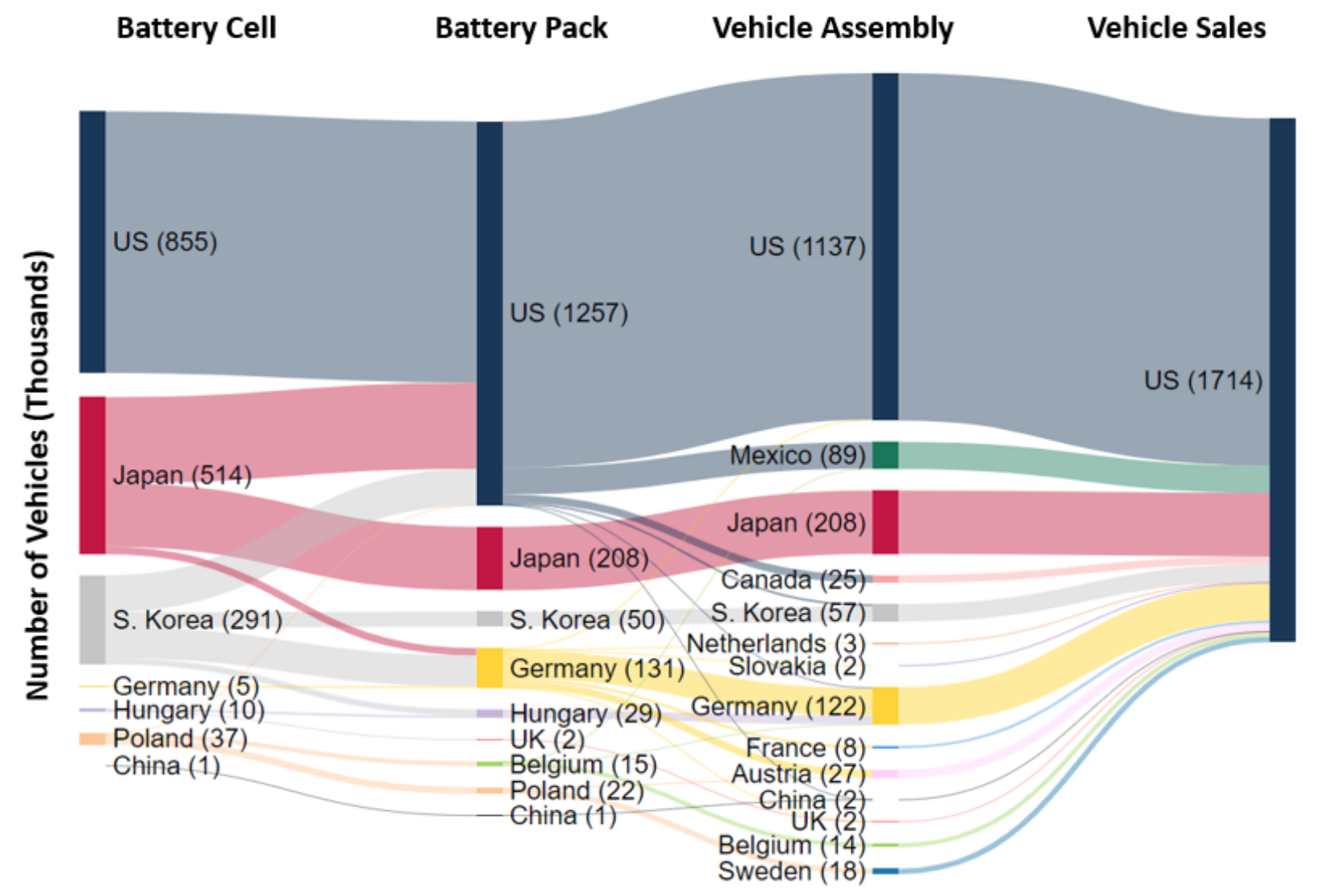

FIGURE 4-2 Number of Li-ion battery packs (or vehicles) supplied to the U.S. PEV market by production location, 2010-2020. (From left to right: battery cell production location, battery pack production location, vehicle assembly location, and vehicles sold in the U.S.) 


\section{LITHIUM-ION BATTERIES IN HEVS}

PEVs are not the only passenger vehicles that use $\mathrm{Li}$-ion batteries. Li-ion batteries are also found in HEVs powered solely by gasoline but with an onboard battery for short-range propulsion. Hybrids considered here include both full hybrids, where the battery is capable of unassisted propulsion, and mild hybrids, where the battery is able to assist the internal combustion engine. For HEVs, the battery supply chain is complicated by the multiple chemistries that have been used for these batteries. Historically, nickel metal hydride (NiMH) batteries have been the most common batteries for HEVs, although the share of Li-ion batteries has grown since 2010, reaching around half the market for full hybrids (FHEVs), and the entire market for mild hybrids (MHEVs), as shown in Figure 5-1. In 2020, 17 models of FHEVs with Li-ion batteries were sold in the U.S.

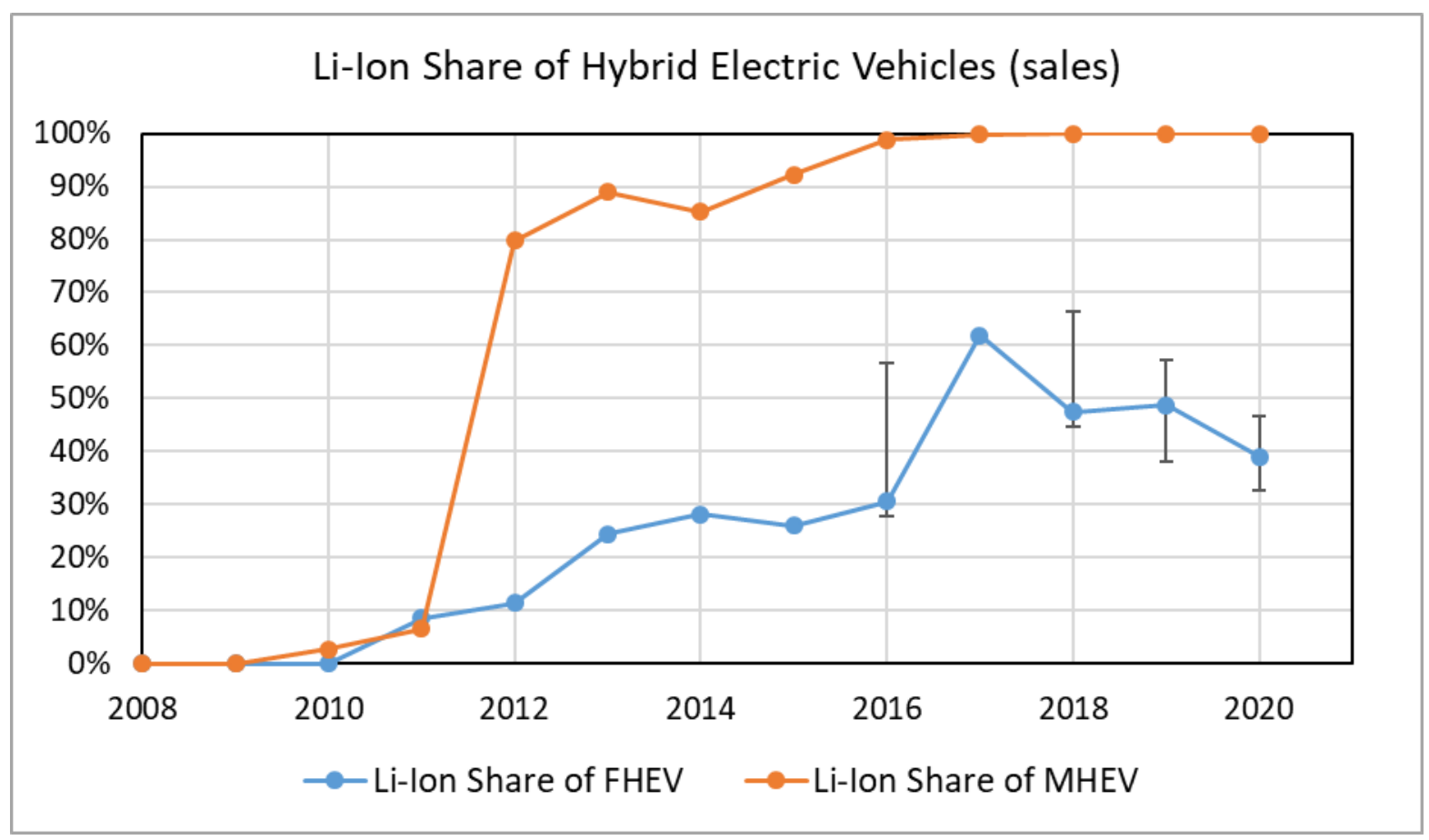

FIGURE 5-1 Share of Li-ion batteries in HEVs sold in the U.S., 2008-2020.

Among vehicle manufacturers, Toyota (including the Lexus brand) is the dominant manufacturer of HEVs, with approximately two-thirds of the cumulative sales since 1999. The majority of these vehicles have had their batteries supplied by Panasonic (or Primearth EV, a joint venture of Panasonic and Toyota). Toyota has used both NiMH and Li-ion batteries, sometimes using both within a single model (such as in the MY2020 Toyota Prius). Because the precise battery mix is not known, it is shown with uncertainty bars in Figure 5-1. Among all full hybrids with Li-ion batteries, Panasonic has supplied more than half of the batteries, followed by LG Chem, Blue Energy (GS Yuasa), and Vehicle Energy Japan (Hitachi). Nearly all of the mild 
hybrid batteries have been supplied by LG Chem. Characteristics of the Li-ion batteries for all HEVs are presented in Table B-3 in Appendix B.

Relative to PEVs, HEVs have much smaller battery capacities. Full hybrids have a typical Li-ion battery capacity of around $1.3 \mathrm{kWh}$, while mild hybrids have an average battery capacity of under $0.5 \mathrm{kWh}$. For comparison, BEV battery capacities vary between 20 and 100 $\mathrm{kWh}$, and most PHEVs have battery capacities between 5 and $20 \mathrm{kWh}$. Because of this disparity in per-vehicle capacity, the total capacity of Li-ion batteries is much higher for PEVs than for HEVs. In 2020, total HEV sales contained $420 \mathrm{MWh}$ of Li-ion batteries, with $230 \mathrm{MWh}$ installed in FHEVs and 190 MWh in MHEVs. This was up nearly 30\% from 2019, largely due to the growth in sales of mild hybrids [15]. 


\section{FUTURE EV BATTERY CAPACITY EXPANSIONS}

Forecasts of the global Li-ion battery market for automotive use unanimously show continued growth through 2030. Figure 6-1 compares forecasts of total Li-ion battery production capacity and demand of light- and heavy-duty vehicles from multiple sources. Avicenne has historically published and updated projections for battery production and use across all use segments $[16,17,18]$. The Bank of Montreal (BMO) published an in-depth analysis about the historical market for electric vehicle batteries and included projections for growth through 2030 [19]. Bloomberg New Energy Finance (BNEF) publishes an Annual Electric Vehicle (EV) Outlook, which includes the total demand for EVs worldwide as well as global production capacity estimates, up to 2030 [20, 21, 22]. Circular Energy Storage (CES) Research and Consulting has provided future Li-ion battery demand for light- and heavy-duty vehicles through 2030 [23, 24]. Researchers from Leiden University (LU) and Argonne National Laboratory (ANL) projected PEV battery demand based on two scenarios of global PEV stock from the International Energy Agency's (IEA) 2020 Global EV Outlook. The stated policies scenario incorporates existing government policies, while the sustainable development scenario is based on the IEA EV Outlook's more optimistic scenario, which is compatible with the climate goals of the Paris agreement and assumes that PEV sales account for $30 \%$ of global light-duty vehicle sales in 2030 [25]. Nextbigfuture writer and researcher Brian Wang published an article projecting global growth of Li-ion battery demand through 2030 based on expansion announcements by major battery manufacturers [26]. The German consulting firm Roland Berger forecast the growth in both the market demand and production capacity for Li-ion batteries by application through 2030 [27]. S\&P Global Market Intelligence recently estimated global Li-ion battery production capacity for PEVs through 2025 [28]. A 2019 report by the World Economic Forum (WEF) Global Battery Alliance, a public-private collaboration platform working to help establish a sustainable battery value chain, similarly projects PEV battery demand for 2025 and 2030 [29]. Forecasts from McKinsey \& Company and Transport \& Environment show similar trends but focus only on European production and are not plotted in Figure 6-1 [30, 31].

By 2025 , forecasts range between $190 \mathrm{GWh}$ and $1050 \mathrm{GWh}$ of annual Li-ion battery production for on-road vehicles; for 2030, these forecasts range from $700 \mathrm{GWh}$ globally to 2500 $\mathrm{GWh}$. In terms of annual Li-ion battery production capacity globally, estimates increase from about $500 \mathrm{GWh}$ in 2020 to around $1500 \mathrm{GWh}$ in 2025, nearing $2500 \mathrm{GWh}$ by 2030. In Figure 61 , solid lines represent forecasts for Li-ion battery demand, while dashed lines represent capacity. Each of these forecasts accounts for all types of on-road vehicles including passenger vehicles and heavy-duty trucks and buses except for the forecasts from S\&P Global and Leiden \& Argonne, which each forecast only passenger PEVs. 


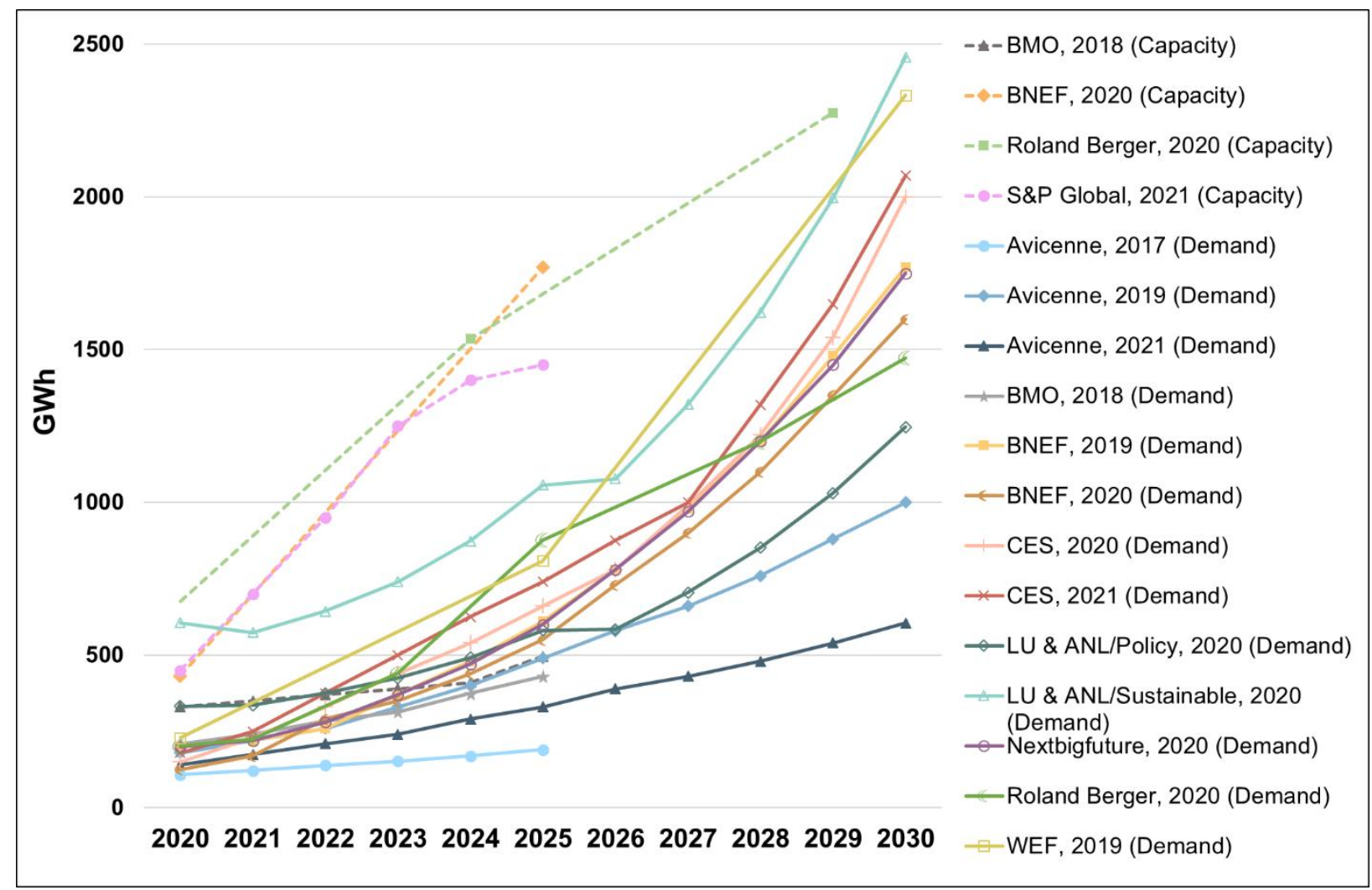

FIGURE 6-1 Future global Li-ion battery demand and production capacity, 2020-2030. BMO: Bank of Montreal, BNEF: Bloomberg New Energy Finance, CES: Circular Energy Storage, LU: Leiden University, ANL: Argonne National Laboratory, WEF: World Economic Forum. Note: Roland Berger provided 2019 estimates instead of 2020, hence the omitted data points for those sources in 2020.

Major Li-ion battery manufacturers have announced plans for, or are in the process of, constructing new Li-ion battery cell factories to support rising PEV markets globally. The top 10 manufacturers globally are ramping up to nearly 3 terawatt-hours (TWh) of production capacity from $180 \mathrm{GWh}$-scale battery factories by 2030[32]. The technology trend is to use less cobalt in the cathode, which points to the importance of continuing to track the key cathode chemistries used in PEV batteries. Based on the announcements made by the major companies, described below, the total battery production capacity could increase to about $80 \mathrm{GWh}$ by 2023 in the U.S alone.

- SK Innovation has started construction of its second Li-ion battery cell factory in Commerce, Jackson County, Georgia, with a planned manufacturing capacity of 11.7 GWh Li-ion cells. It is expected to start production in 2023. The first $9.8 \mathrm{GWh}$ factory, at the same site, has been under construction since March 2019 with a planned production start in 2022. The combined output would be $21.5 \mathrm{GWh}$ annually. However, in February 2021, the U.S. International Trade Commission (ITC) announced a verdict in a trade-secret dispute between SK Innovation and LG Chem, which will ban SK Innovation's PEV battery business (including importation, domestic production, and sale 
of batteries for PEVs) in the U.S. for 10 years [33]. It is uncertain whether SK Innovation will complete the construction of the two factories, and which battery supplier would provide the required volume of batteries to Ford and Volkswagen. SK Innovation also has a 7.5 GWh factory, with plans to reach $17.3 \mathrm{GWh}$ by 2022, in Kamarom, Hungary [34, 35].

- Panasonic plans to invest $\$ 100 \mathrm{M}$ in a PEV battery plant in the U.S. for Tesla and raise its production capacity to $39 \mathrm{GWh}$ per year. Currently, the annual production capacity is about $25 \mathrm{GWh}$. Panasonic will boost the energy density of the PEV batteries it supplies to Tesla by $20 \%$ over the next five years and aims to deliver a cobalt-free battery by 2022 2023. In addition, Tesla is building a pilot battery cell manufacturing line in Fremont, California, and designing its own equipment to produce the cells [36, 37].

- General Motors (GM) and LG Chem announced plans to mass produce battery cells for GM's future PEVs in Lordstown, Ohio, with an expected annual production capacity of $20 \mathrm{GWh}$ by 2023. LG Chem also announced the establishment of a plant in Wroclaw, Poland, with an expected annual production capacity of 65 GWh by 2023 . This factory will mainly supply to the European vehicle manufacturers. LG Chem will also increase the annual production capacity of their factory in China to over $40 \mathrm{GWh}$. This factory will supply to both European and U.S. vehicle manufacturers [38, 39].

- Samsung SDI has opened a production facility in Göd, Hungary, which has an expected capacity of 12 million cells per month supplying batteries to BMW and Volkswagen [40, $41,32]$.

- CATL (China's Contemporary Amperex Technology) is building its first overseas plant in Erfurt, Germany, and is considering a U.S. factory. The German factory is expected to have an initial annual capacity of $14 \mathrm{GWh}$ by 2022 with expansion to $24 \mathrm{GWh}$ planned in the years to follow. The company's clients include BMW and Volvo. CATL has announced it is readying a new and cheaper type of battery technology that does not rely on expensive nickel or cobalt as a key component $[42,43]$.

- Volkswagen has announced plans to build six gigawatt-hour scale factories in Europe by 2030, with a total annual capacity of $240 \mathrm{GWh}$. These plants will be manufacturing prismatic cells for the batteries. The first two of these manufacturing plants will be in Germany and Sweden [44]. 


\section{DISCUSSION}

With over 300,000 annual PEV sales, about 20 different battery cell and pack manufacturers are currently supplying about $20 \mathrm{GWh}$ of batteries annually for the U.S. market. PEV adoption is projected to grow with more long-range models to be introduced into the market. The battery demand, in both number of units and capacity, will grow substantially. The batteries used in PEVs sold in the U.S. have been largely domestically sourced. In terms of total battery capacity since 2010, over half of all cells have been produced in the U.S., as have nearly $90 \%$ of all battery packs. This trend toward domestic production has grown over time, with $69.6 \%$ of battery cells and $87.2 \%$ of battery packs, again in terms of battery capacity, produced in the U.S. in 2020. Most of this production is for BEVs rather than for PHEVs, both because of the larger capacity intrinsic to BEVs as well as the greater diversity of manufacturers of PHEVs. However, the large share of domestic production is due to a single player; in 2020, Panasonic alone accounted for $84.9 \%$ of U.S. battery cell production, while Tesla/Panasonic (combined) accounted for $87.7 \%$ of U.S. pack production, in terms of capacity. In addition to the facilities in Nevada and California for Tesla/Panasonic, there are domestic battery production locations for other OEMs in Michigan, Tennessee and South Carolina.

Through 2020, the total amount of battery capacity installed in long-range BEVs (those vehicles with over 150 miles of all-electric range) was $67.8 \mathrm{GWh}$. In short-range BEVs, the battery capacity total was $4.9 \mathrm{GWh}$, while PHEVs had $8.1 \mathrm{GWh}$ and HEVs had 2.0 GWh. Figure 7-1 presents the annual shares of these vehicle types, showing that the total Li-ion capacity in PEVs is predominantly in long-range BEVs. This is due both to the total number of sales of these vehicles as well as the relative size of the batteries. Since 2010, the market has shifted from short-range to long-range BEV. Proportionally, PHEVs have decreased in total battery share, as have hybrids. However, this has the potential to change if HEVs are viewed as a cost-effective way for automakers to meet compliance standards. According to the U.S. Environmental Protection Agency, HEVs surpassed 6\% of total light-duty vehicles sold in the U.S. in 2020, more than doubling from 2018 due to increased availability of hybrid vehicles, particularly mild hybrids [15]. 


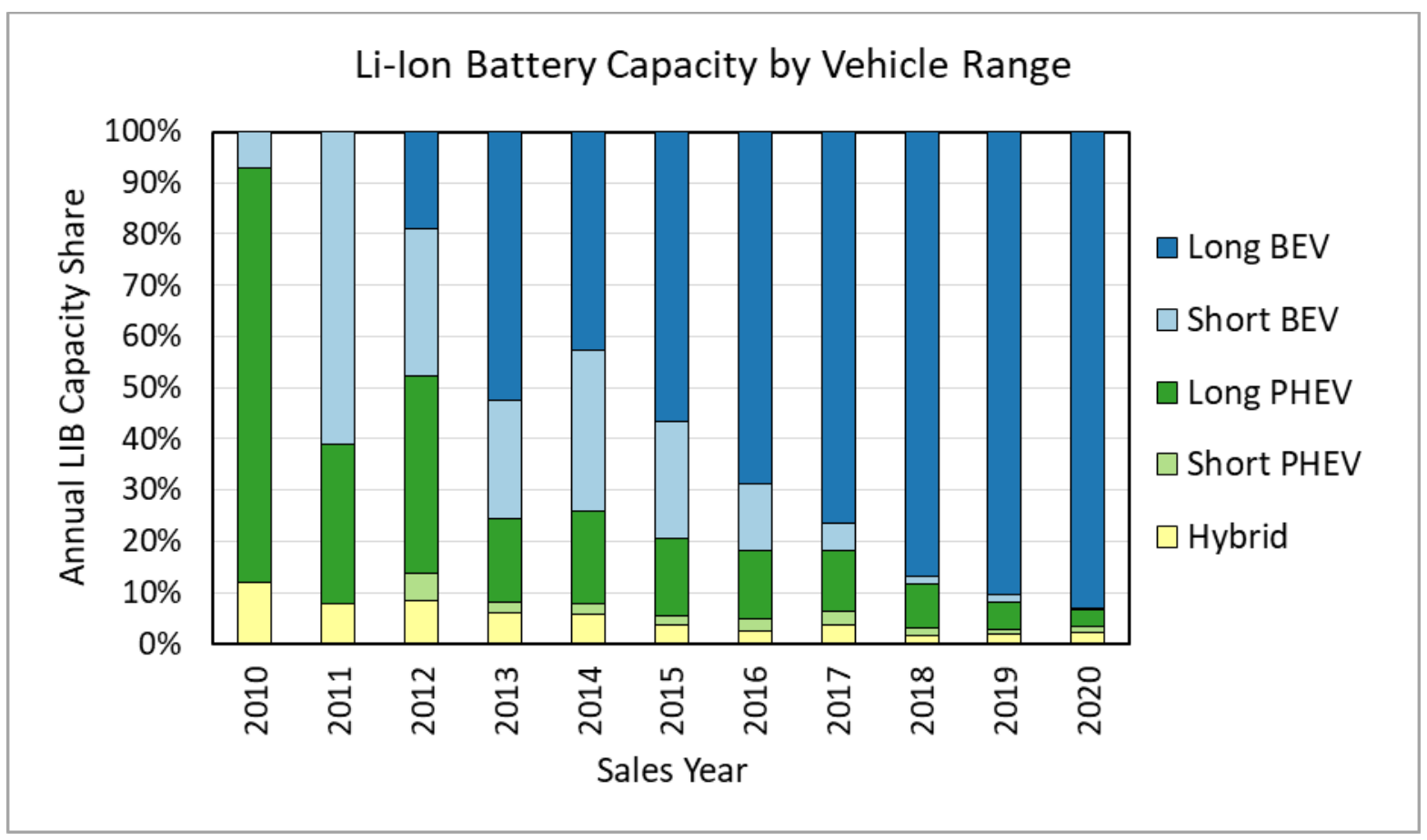

FIGURE 7-1 Share of total annual Li-ion battery capacity by long- and short-range BEV (above/below 150 miles), long- and short- range of PHEVs (above/below 20 miles), and HEVs in the U.S., 2010-2020.

With the evolving technology trend such as using less cobalt in the cathode, it is important to track the key cathode chemistries used in PEV batteries in future research. Understanding the battery supply chain is particularly important for the strategic planning and development of a battery recycling infrastructure to secure critical materials supply and enable a circular economy. The battery manufacturing process can generate a considerable amount of manufacturing scrap due to limitations of current technologies; the battery modeling tool BatPaC estimates that $7.8 \%$ of the valuable cathode material used for the cell production process does not end up in battery cells, and 5\% of the produced cells fail quality inspection and are rejected [45]. These manufacturing scraps contain critical materials such as cobalt and lithium and are available for immediate recycling. Knowing the locations of battery production sites can assist in siting recycling facilities. Similarly, batteries in PEVs will ultimately be available for recycling at the end of their service life [46]. While some of the spent PEV battery packs may have a second life for less-demanding applications, they will be available for recycling eventually. Tracking where vehicles are sold and registered enables optimal siting of future battery recycling facilities. Future efforts to further identify secondary sales and decommissioning will improve such siting efforts. 


\section{REFERENCES}

[1] Argonne E-drive Monthly Update (2021) https://www.anl.gov/es/light-duty-electric-drivevehicles-monthly-sales-updates, Argonne National Laboratory.

[2] D. Gohlke and Y. Zhou (2020) Impacts of Electrification of Light-Duty Vehicles in the United States, 2010 - 2019, ANL/ESD-20/4. June. https://www.osti.gov/servlets/purl/1642114.

[3] S. Boyd (2020) Batteries and Electrification Overview, 2020 Vehicle Technologies Office Annual Merit Review, June 2020, https://www.energy.gov/sites/prod/files/2020/08/f77/Boyd-2020_AMR_PlenaryBatteries_and_Electrification_Overview_0.pdf.

[4] J. Eddy, A. Pfeiffer, and J. Staai (2019) Recharging economies: The EV-battery manufacturing outlook for Europe, https://www.mckinsey.com/industries/oil-and-gas/ourinsights/recharging-economies-the-ev-battery-manufacturing-outlook-for-europe

[5] International Council on Clean Transportation (2018) Power Play: How Governments Are Spurring The Electric Vehicle Industry, https://theicct.org/sites/default/files/publications/ EV_Government_WhitePaper_20180514.pdf

[6] C. McKerracher et al. (2020) Electric Vehicle Outlook, https://about.bnef.com/electricvehicle-outlook/

[7] Wood Mackenzie (2020) Electric Car Forecast to 2040, https://www.woodmac.com/ourexpertise/capabilities/electric-vehicles/2040-forecast/

[8] K. E., Stromsta (2020) Electric Vehicle Sales Set to Crash in 2020 Amid Coronavirus and Oil Price Shocks. April. https://www.greentechmedia.com/articles/read/electric-vehiclesales-set-to-crash-in-2020-as-coronavirus-bites-and-oil-stays-cheap

[9] M. Woodward et al. (2020) Electric Vehicles: Setting a course for 2030. July. https://www2.deloitte.com/us/en/insights/focus/future-of-mobility/electric-vehicle-trends2030.html

[10] Wood Mackenzie (2020) Discover new opportunities with complete coverage of the energy storage market. https://www.woodmac.com/research/products/power-andrenewables/energy-storage-service/

[11] Tesla, Inc. (2020) Form 10-Q for Quarterly Period Ended June 30, 2020. EDGAR. Securities and Exchange Commission, https://www.sec.gov/Archives/edgar/data/1318605/000156459020033670/tsla10q_20200630.htm

[12] J. Voelcker (2016) Bolt EV Powertrain: How did GM and LG collaborate on design, production? https://www.greencarreports.com/news/1102176_bolt-ev-powertrain-how-didgm-and-lg-collaborate-on-design-production

[13] F. Lambert (2018) Nissan finally sells its battery cell manufacturing division. https://electrek.co/2018/08/03/nissan-sells-battery-cell-manufacturing-division/

[14] R. H. Schwartz, M. Cribioli, and D. Gohlke (2021) Domestic Sales Mix of Plug-In Electric Vehicles by Trim Variant and Vehicle Characteristics. Argonne National Laboratory report ANL/ESD-21/5.

[15] United States Environmental Protection Agency (2020) Automotive Trends Report, EPA420-R-20-006, March, https://www.epa.gov/automotive-trends/download-automotivetrends-report 
[16] C. Pillot (2017) Lithium-ion Battery Raw Material Supply and Demand 2016 - 2025, June. http://www.avicenne.com/pdf/LithiumIon\%20Battery\%20Raw\%20Material\%20Supply\%20and\%20Demand\%2020162025\%20C.\%20Pillot\%20-\%20M.\%20Sanders\%20Presentation\%20at\%20AABCUS\%20San\%20Francisco\%20June\%202017.pdf

[17] C. Pillot (2019) The Rechargeable Battery Market and Main Trends 2018 - 2030, May. https://www.bpifrance.fr/content/download/76854/831358/file/02\%20-\%20Presentation\%2 0Avicenne\%20-\%20Christophe\%20Pillot\%20-\%2028\%20Mai\%202019.pdf

[18] C. Pillot and M. Sanders (2021) Tutorial 3 - The Rechargeable Battery Market and Main Trends 2020 - 2030, Avicenne Energy, March.

[19] K. Berman et al. (2018) The Lithium Ion Battery and the EV Market: The Science Behind What You Can't See, February. https://bmo.bluematrix.com/docs/pdf/079c275e-35404826-b143-84741aa3ebf9.pdf

[20] C. McKerracher (2019) Electric Vehicle Outlook 2019. https:/bnef.turtl.co/story/evo2019

[21] BloombergNEF (2020) Electric Vehicle Outlook 2020. https://bnef.turtl.co/story/evo-2020/

[22] N. Albanese (2020) Presentation - Electric Vehicle Outlook 2020, 20-IEPR-02. https://efiling.energy.ca.gov/GetDocument.aspx?tn=233410\&DocumentContentId=65926

[23] E. Melin (2020) The dynamics of the EV battery end-of-life market, Circular Energy Storage Research and Consulting, October.

[24] E. Melin (2021) The lithium-ion battery life cycle report, Circular Energy Storage Research and Consulting.

[25] C. Xu et al. (2020) Future material demand for automotive lithium-based batteries, December. https://www.nature.com/articles/s43246-020-00095-X

[26] B. Wang (2020) World Battery Production, February. https://www.nextbigfuture.com/2020/02/world-battery-production.html

[27] W. Bernhart et al. (2020) Rising opportunities for battery equipment manufacturers, Roland Berger, December. https://content.rolandberger.com/hubfs/Roland_Berger_BatteryProduction-Report_2020.pdf

[28] A. Yu and M. Sumangil (2021) Top electric vehicle markets dominate lithium-ion battery capacity growth, February. https://www.spglobal.com/marketintelligence/en/newsinsights/blog/top-electric-vehicle-markets-dominate-lithium-ion-battery-capacity-growth

[29] World Economic Forum Global Battery Alliance (2019) A Vision for a Sustainable Battery Value Chain in 2030: Unlocking the Full Potential to Power Sustainable Development and Climate Change Mitigation, September. http://www3.weforum.org/docs/ WEF_A_Vision_for_a_Sustainable_Battery_Value_Chain_in_2030_Report.pdf

[30] J. Eddy, A. Pfeiffer, and J. van de Staaij (2019) Recharging economies: The EV-battery manufacturing outlook for Europe, June. https://www.mckinsey.com/industries/oil-andgas/our-insights/recharging-economies-the-ev-battery-manufacturing-outlook-for-europe

[31] L. Mathieu and C. Mattea (2021) From dirty oil to clean batteries, Transport \& Environment, March. https://www.transportenvironment.org/sites/te/files/publications/ 2021_02_Battery_raw_materials_report_final.pdf

[32] J. Park (2019) Electrical Components KR EV Battery 2020: Momentum to rebuild. http://www.skc.co.kr/upload/ir/20191216/20191216134740943289.pdf

[33] B. Foldy (2021) Ford, Volkswagen EV Battery Supplier Dealt Setback by Trade Commission. https://www.wsj.com/articles/ford-volkswagen-ev-battery-supplier-dealtsetback-by-trade-commission-11612997534 
[34] P. Sigal (2020) How Europe Will Become EV Battery Powerhouse. https://europe.autonews.com/automakers/how-europe-will-become-ev-battery-powerhouse

[35] M. Herh (2020) SK Innovation Taking Aim at 3rd Place in Global Electric Vehicle Battery Market. http://www.businesskorea.co.kr/news/articleView.html?idxno=55760

[36] I. Fujino and T. Shiraishi (2020) Panasonic to invest $\$ 100 \mathrm{~m}$ in EV battery plant in US for Tesla. https://asia.nikkei.com/Business/Automobiles/Panasonic-to-invest-100m-in-EVbattery-plant-in-US-for-Tesla

[37] B. Schmidt (2020) Panasonic Promises Big Efficiency Boost to Tesla EV Batteries, and No Cobalt. https://thedriven.io/2020/08/03/panasonic-promises-big-efficiency-boost-to-teslaev-batteries-and-no-cobalt/

[38] H. Kim (2020) LG Chem Expects Battery Revenue To Double by 2025. https://europe.autonews.com/suppliers/lg-chem-expects-battery-revenue-double-2025

[39] J. Jacuzzi, T Henderson, and W-J. Yoo (2019) General Motors and LG Chem Team Up to Advance Toward an All-Electric Future, Add Jobs in Ohio.

https://media.gm.com/media/us/en/gm/news.detail.html/content/Pages/news/us/en/2019/de c/1205-lgchem.html

[40] Argus (2019) Samsung SDI to Expand Hungary EV battery plant.

https://www.argusmedia.com/en/news/1996257-samsung-sdi-to-expand-hungary-evbattery-plant

[41] M. Kane (2020) Samsung SDI Expands Its Battery Plant in Hungary. https://insideevs.com/news/400155/samsung-sdi-expands-battery-plant-hungary/

[42] Contemporary Amperex Technology (2019) CATL Starts Construction of Its First Overseas Factory in Germany, https://www.prnewswire.com/news-releases/catl-startsconstruction-of-its-first-overseas-factory-in-germany-300941142.html

[43] S. Hanley (2019) Energy Storage News: CATL Factory In Germany \& Rio Tinto's Lithium Plant In California. https://cleantechnica.com/2019/10/22/energy-storage-news-catlfactory-in-germany-rio-tintos-lithium-plant-in-california/

[44] A. J. Hawkins (2021) Here are the biggest announcements from Volkswagen's battery event, The Verge, March. https://www.theverge.com/2021/3/15/22325813/vw-volkswagenpower-day-battery-electric-car-announcement

[45] BatPaC: Battery Manufacturing Cost Estimation (2020) Argonne National Laboratory. Available at: https://www.anl.gov/tcp/batpac-battery-manufacturing-cost-estimation

[46] J. Kelly, D. Gohlke, L. Gaines, M. Wang (2019) Proposed Methodology for Assessing the Quantity of Available Lithium-ion Batteries for Recycling in the United States. Systems Assessment Center, Argonne National Laboratory. https://anl.app.box.com/s/4r9a6jx2g2lf0y5f1iquiisxcmhcpbqi7 


\section{APPENDIX A: LI-ION BATTERY CELL AND PACK FLOW DIAGRAMS FOR PEVS}

Figures A-1 to A-10 show battery capacity supplied by manufacturer. Note that the following annual diagrams for battery capacity by manufacturer are on the same scale: one unit corresponds to the same height in each figure. Because of this, one can easily compare the growth in the PEV market over time. Also note that the values are battery capacity measured in MWh.

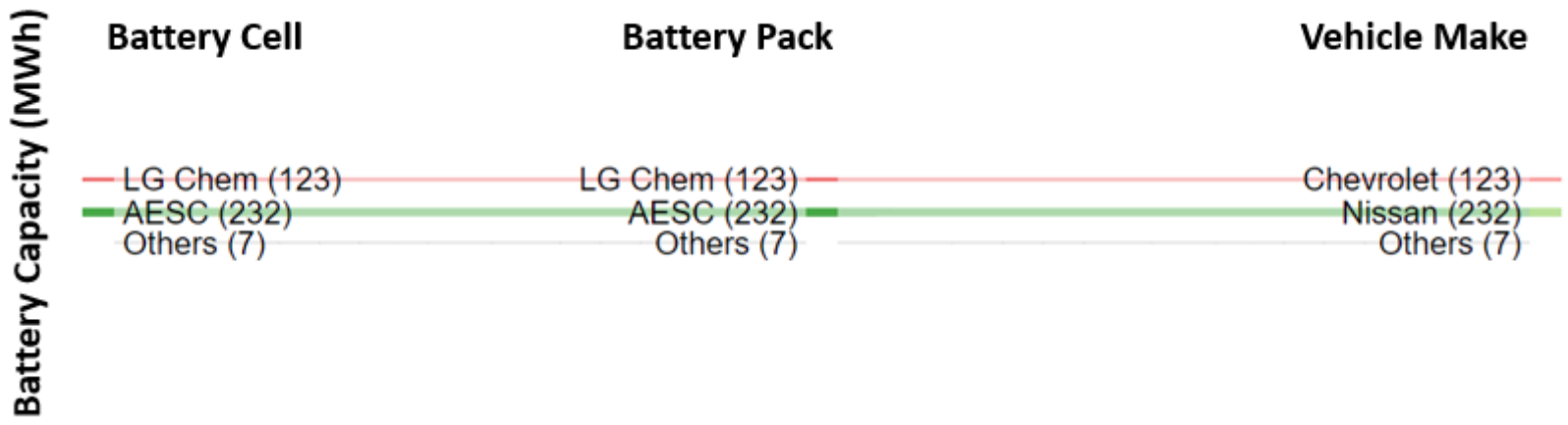

FIGURE A-1 2011 Total capacity (MWh) of Li-ion batteries supplied to the U.S. PEV market by manufacturer. "Others" for battery cell includes Li-tec and GS Yuasa; "Others" for battery pack includes Accumotive and GS Yuasa. "Others" for vehicle makes includes Smart and Mitsubishi.

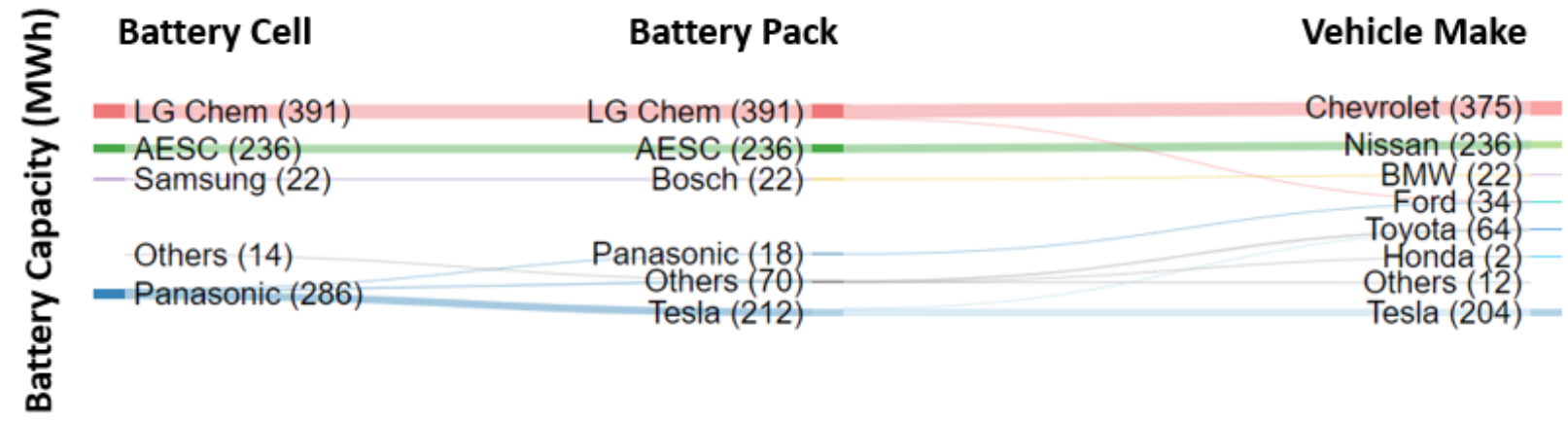

FIGURE A-2 2012 Total capacity (MWh) of Li-ion batteries supplied to the U.S. PEV market by manufacturer. "Others" for battery cell includes Li-tec, GS Yuasa, and Toshiba; "Others" for battery pack includes Accumotive, GS Yuasa, Primearth EV Energy, and Toshiba. "Others" for vehicle makes includes Smart and Mitsubishi. 


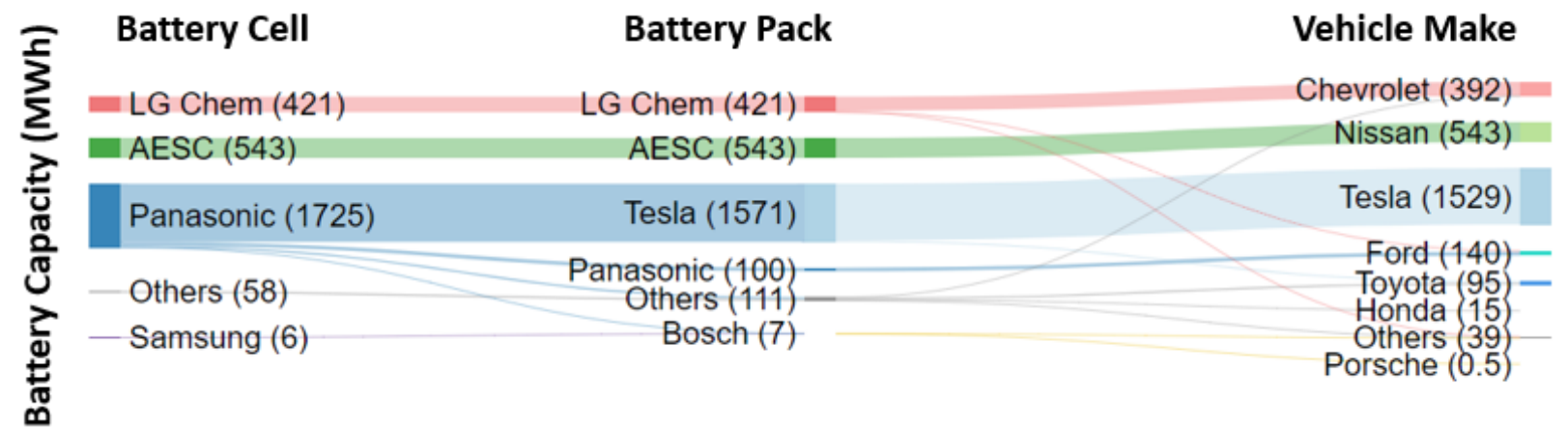

FIGURE A-3 2013 Total capacity (MWh) of Li-ion batteries supplied to the U.S. PEV market by manufacturer. "Others" for battery cell includes Li-tec, GS Yuasa, Toshiba, Blue Energy, and A123; "Others" for battery pack includes Accumotive, GS Yuasa, Primearth EV Energy, Toshiba, Blue Energy, and A123. "Others" for vehicle makes includes Smart, Mitsubishi, Fiat, and Cadillac.

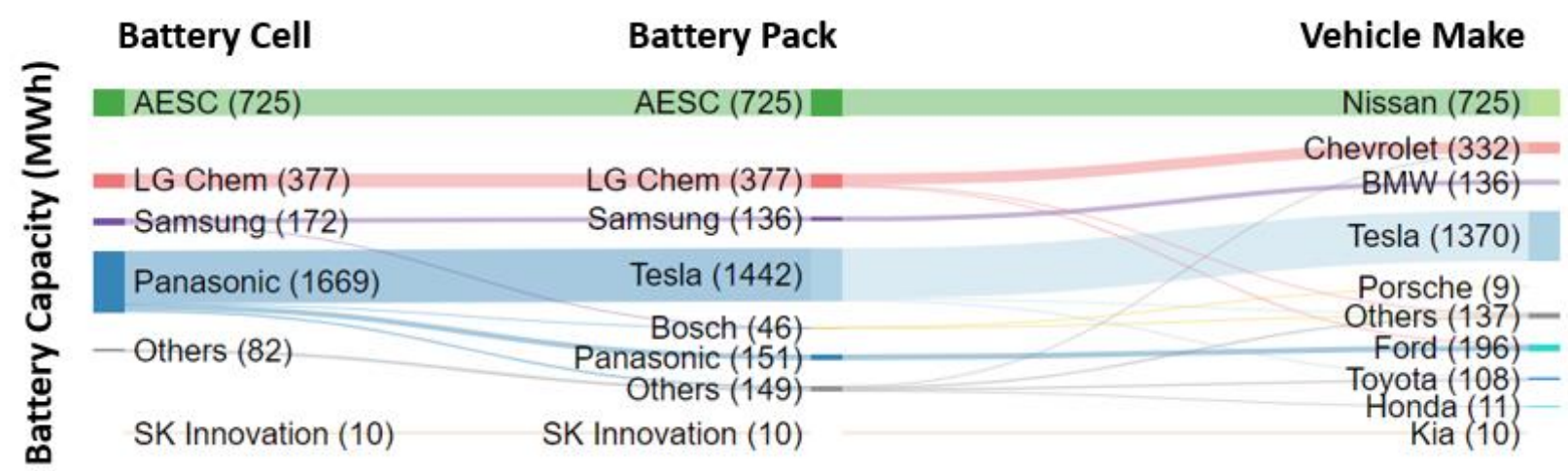

FIGURE A-4 2014 Total capacity (MWh) of Li-ion batteries supplied to the U.S. PEV market by manufacturer. "Others" for battery cell includes Li-tec, GS Yuasa, Toshiba, Blue Energy, and A123; "Others" for battery pack includes Accumotive, GS Yuasa, Primearth EV Energy, Toshiba, Blue Energy, A123 and Sanyo. "Others" for vehicle makes includes Smart, Mitsubishi, Fiat, Cadillac, Mercedes, and Volkswagen. 


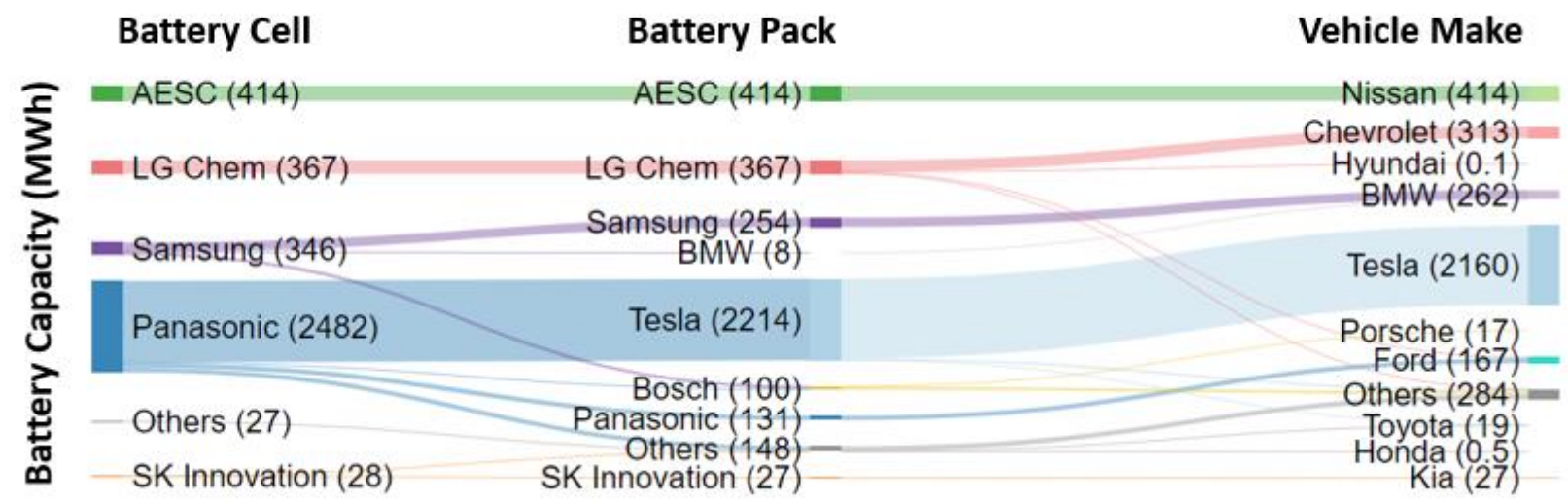

FIGURE A-5 2015 Total capacity (MWh) of Li-ion batteries supplied to the U.S. PEV market by manufacturer. "Others” for battery cell includes Li-tec, GS Yuasa, Toshiba, and Blue Energy; "Others" for battery pack includes Accumotive, GS Yuasa, Primearth EV Energy, Toshiba, Blue Energy, and Sanyo. "Others" for vehicle makes includes Smart, Mitsubishi, Fiat, Cadillac, Mercedes, Volkswagen, and Volvo.

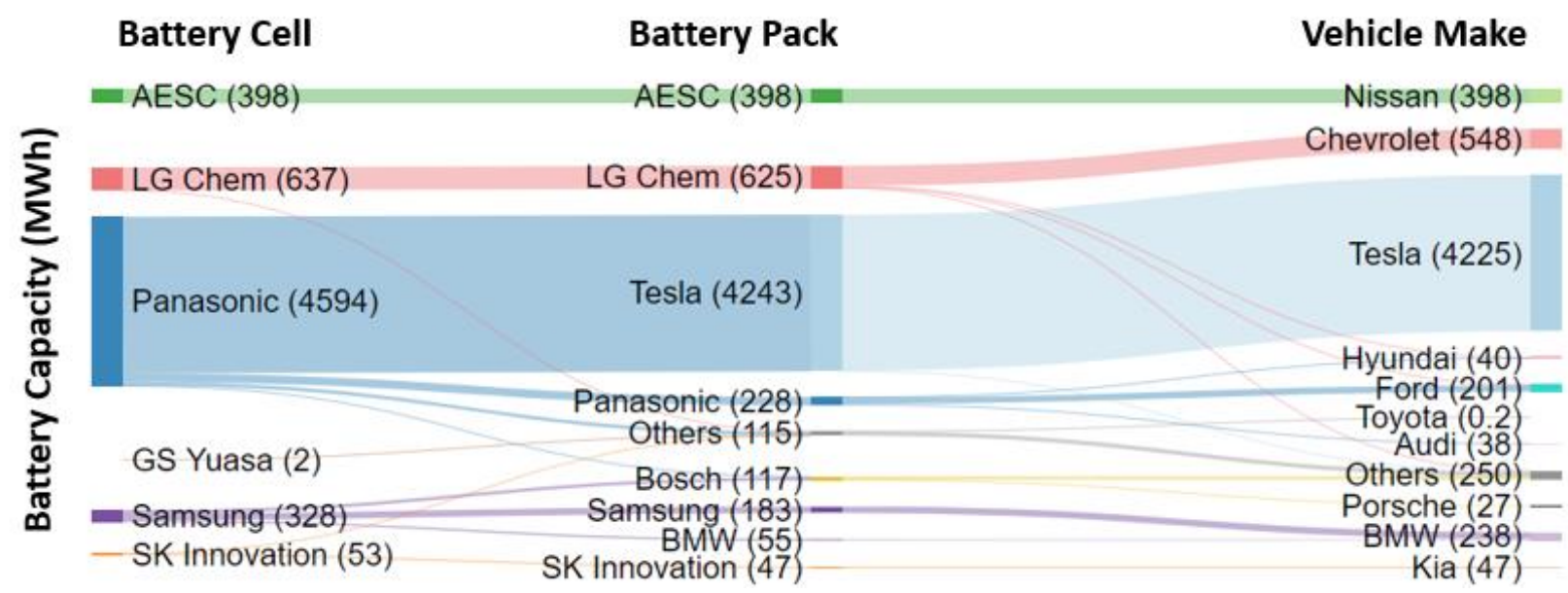

FIGURE A-6 2016 Total capacity (MWh) of Li-ion batteries supplied to the U.S. PEV market by manufacturer. "Others" for battery pack includes Accumotive, GS Yuasa, Primearth EV Energy, and Sanyo. "Others" for vehicle makes includes Smart, Mitsubishi, Fiat, Cadillac, Mercedes, Volkswagen, and Volvo. 


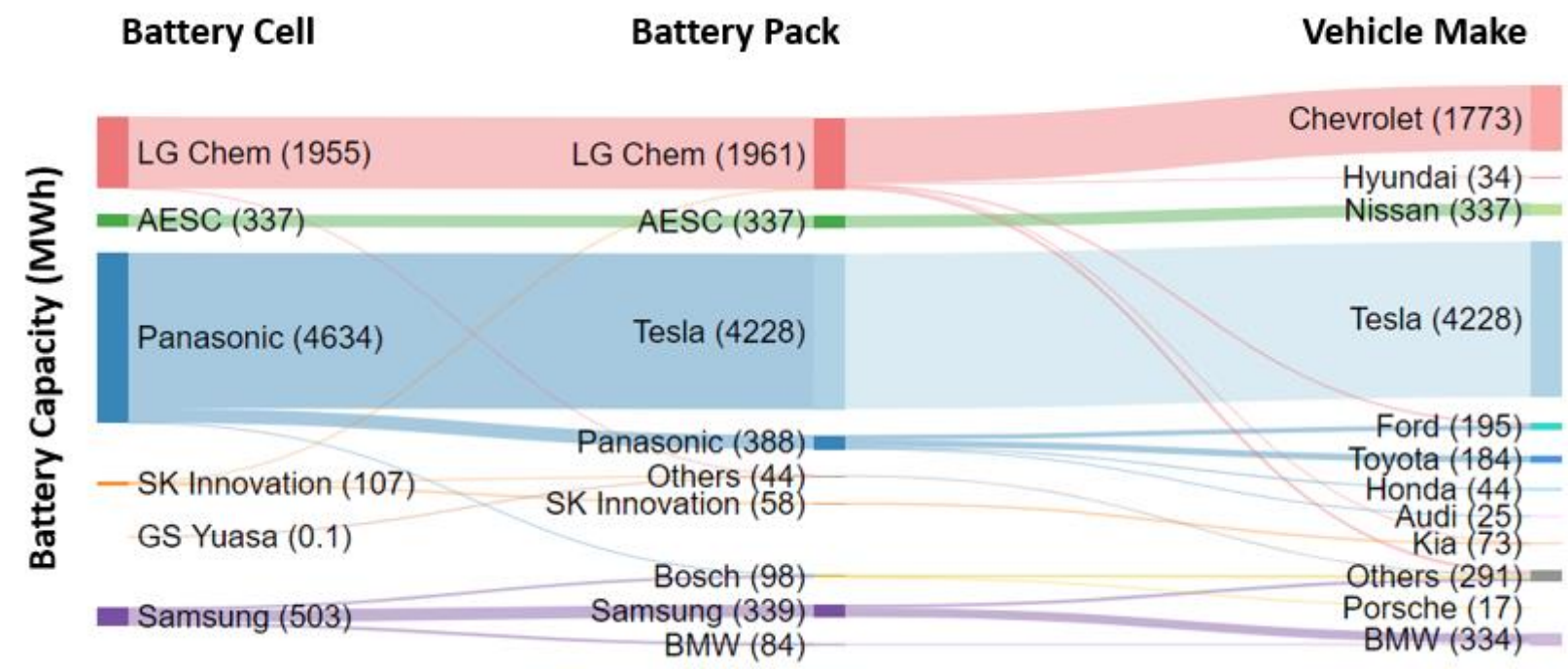

FIGURE A-7 2017 Total capacity (MWh) of Li-ion batteries supplied to the U.S. PEV market by manufacturer. "Others" for battery pack includes Accumotive and GS Yuasa. "Others" for vehicle makes includes Smart, Mitsubishi, Fiat, Cadillac, Mercedes, Volkswagen, Volvo, Chrysler, and MINI.

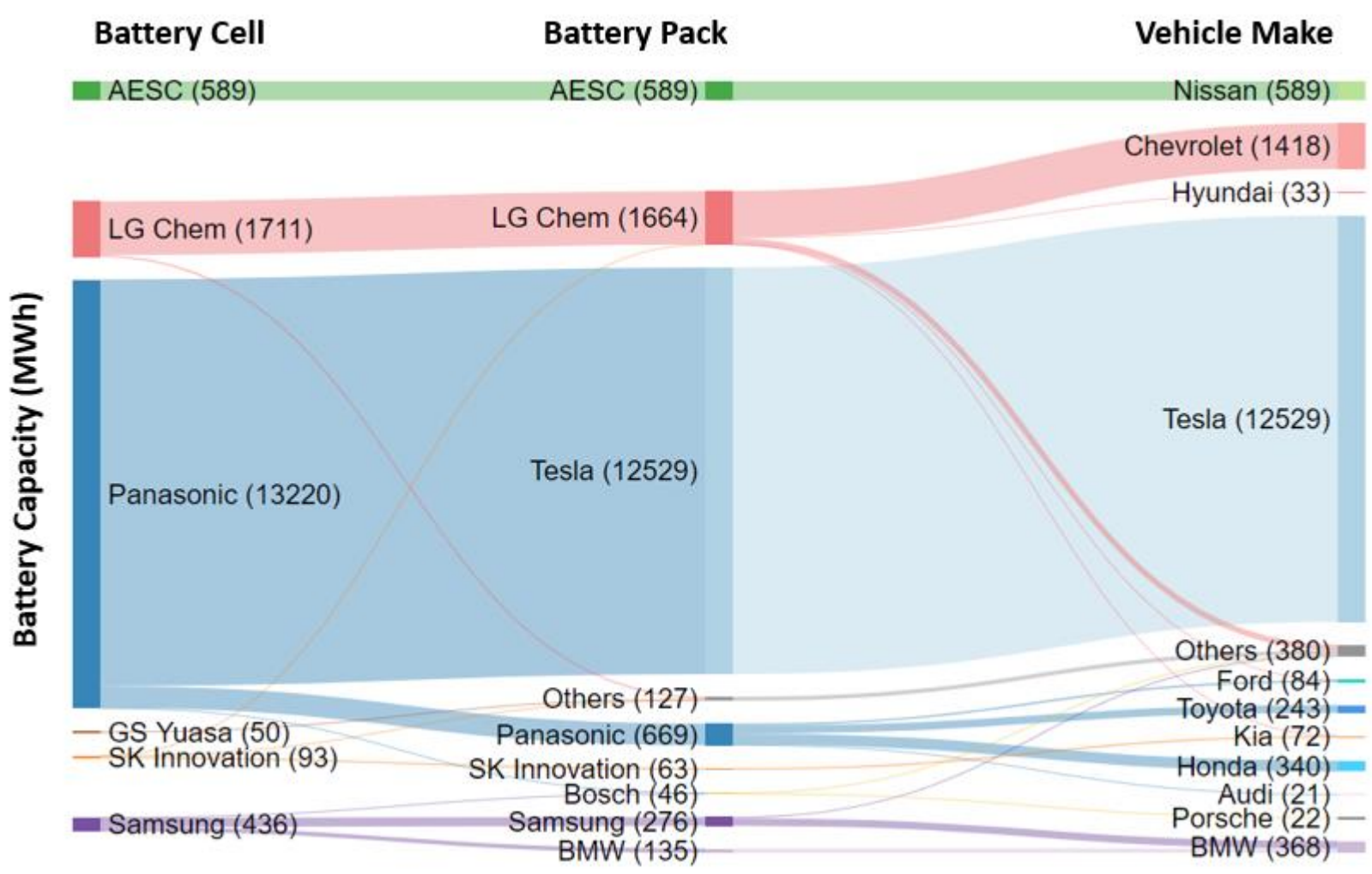

FIGURE A-8 2018 Total capacity (MWh) of Li-ion batteries supplied to the U.S. PEV market by manufacturer. "Others" for battery pack includes Accumotive, GS Yuasa, and Jaguar. "Others" for vehicle makes includes Smart, Mitsubishi, Fiat, Cadillac, Mercedes, Volkswagen, Volvo, Chrysler, MINI, and Jaguar. 


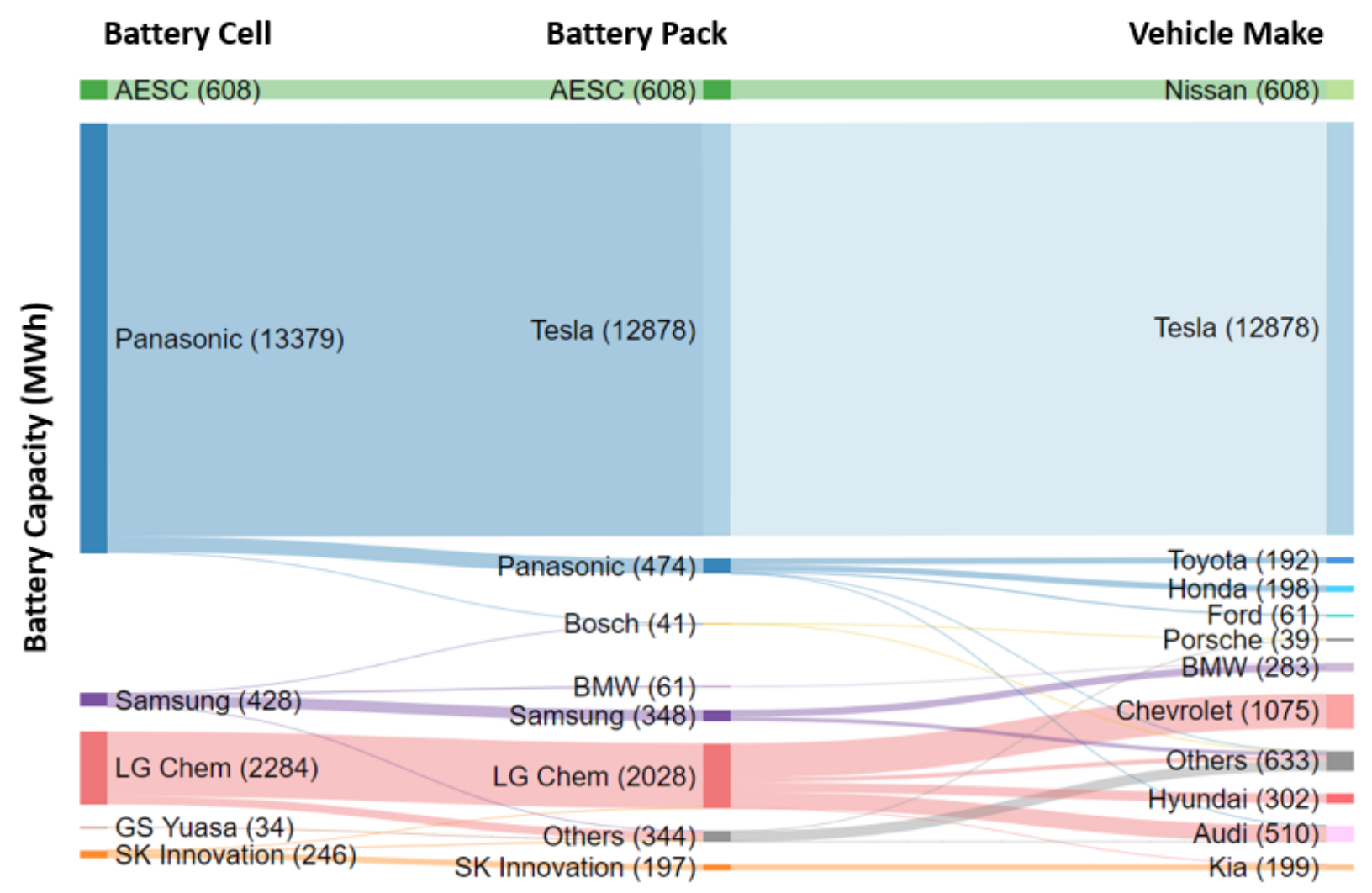

FIGURE A-9 2019 Total capacity (MWh) of Li-ion batteries supplied to the U.S. PEV market by manufacturer. "Others" for battery pack includes Accumotive, GS Yuasa, Jaguar, and Draexlmaier. "Others" for vehicle makes includes Smart, Mitsubishi, Fiat, Cadillac, Mercedes, Volkswagen, Volvo, Chrysler, MINI, Jaguar, Subaru, Land Rover, and Lincoln. 


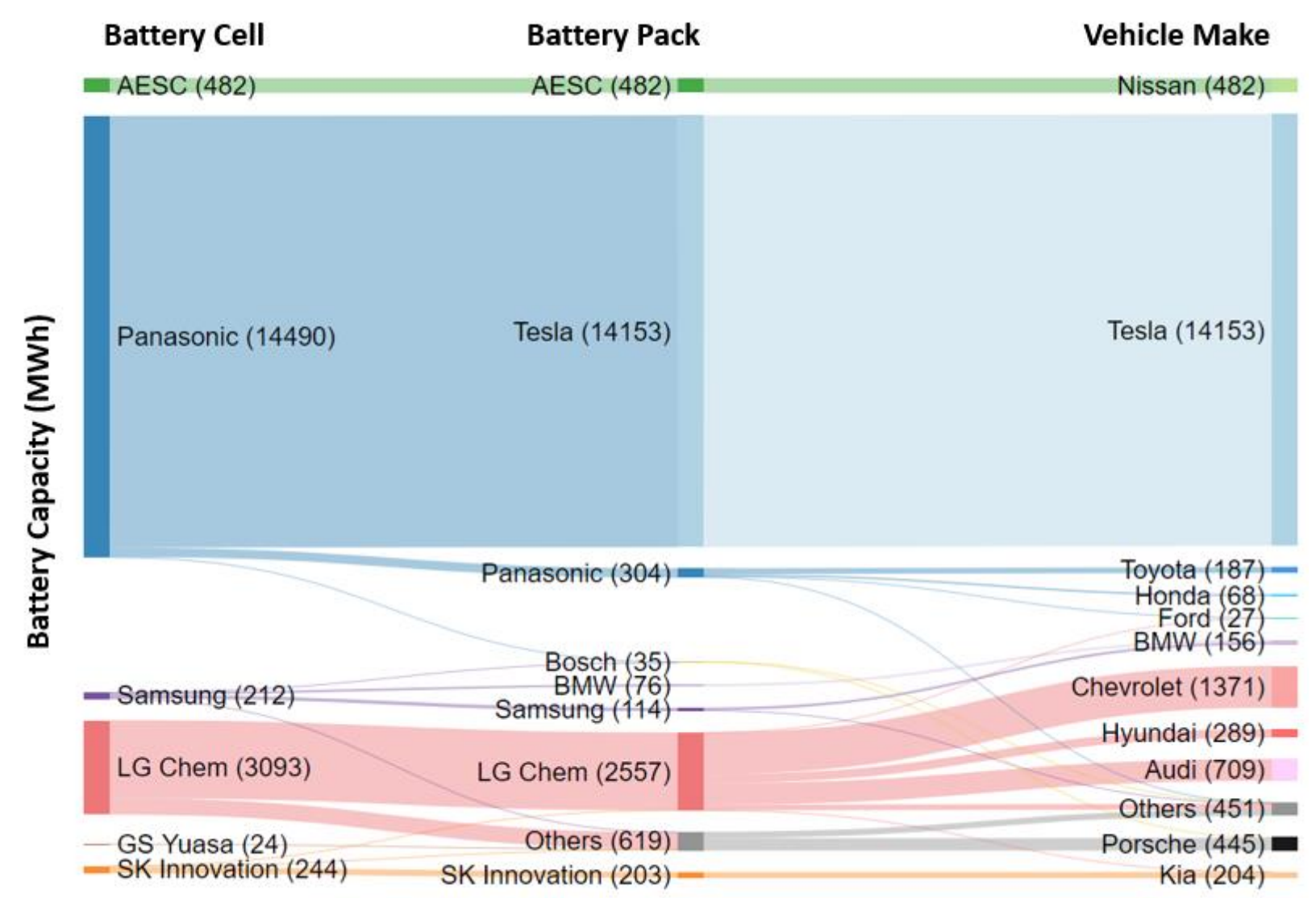

FIGURE A-10 2020 Total capacity (MWh) of Li-ion batteries supplied to the U.S. PEV market by manufacturer. "Others" for battery pack includes Accumotive, GS Yuasa, Jaguar, and Draexlmaier. "Others" for vehicle makes includes Mitsubishi, Fiat, Cadillac, Mercedes, Volkswagen, Volvo, Chrysler, MINI, Jaguar, Subaru, Land Rover, Lincoln, Polestar, and Jeep.

Figures A-11 to A-20 show the number of battery packs (or vehicles) supplied to the U.S. PEV market by manufacturer. Note that the following annual diagrams for battery packs/vehicle units by manufacturer are on the same scale: one unit corresponds to the same height in each figure. Also note that the values are measured in thousands of units. 


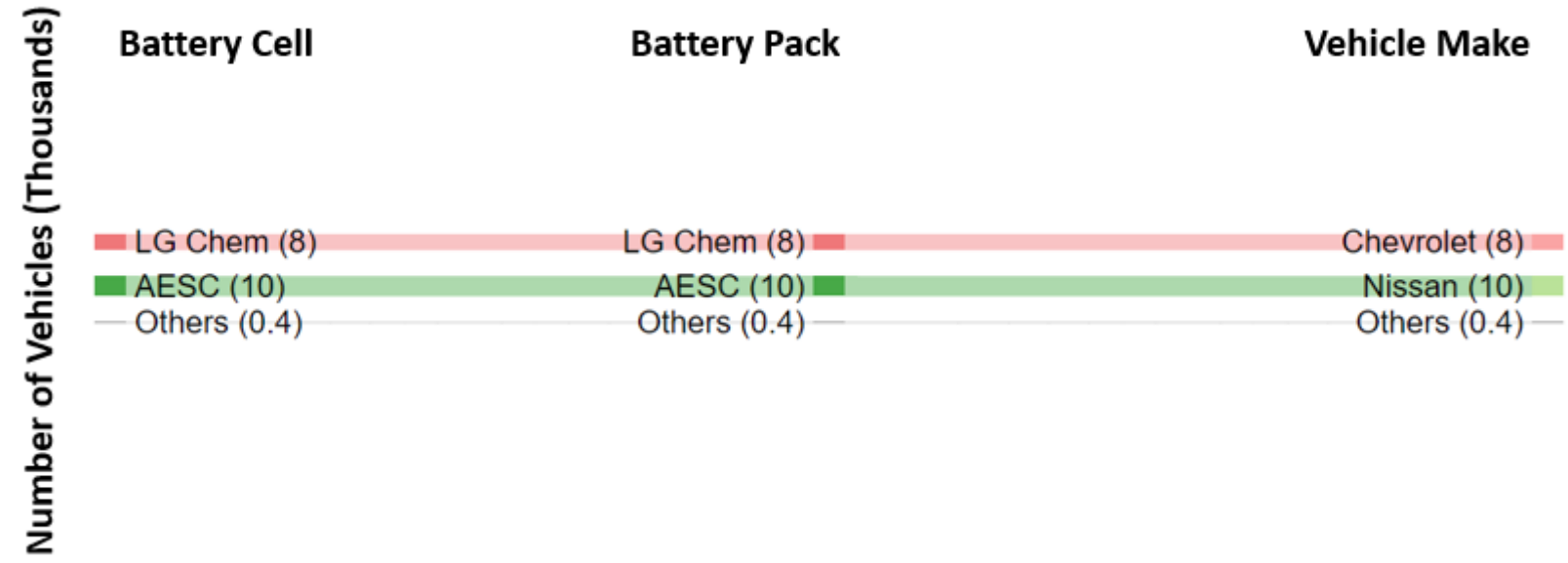

FIGURE A-11 2011 Number of battery packs (or vehicles) supplied to the U.S. PEV market by manufacturer. "Others" for battery cell includes Li-tec and GS Yuasa; "Others" for battery pack includes Accumotive and GS Yuasa. "Others" for vehicle makes includes Smart and Mitsubishi.

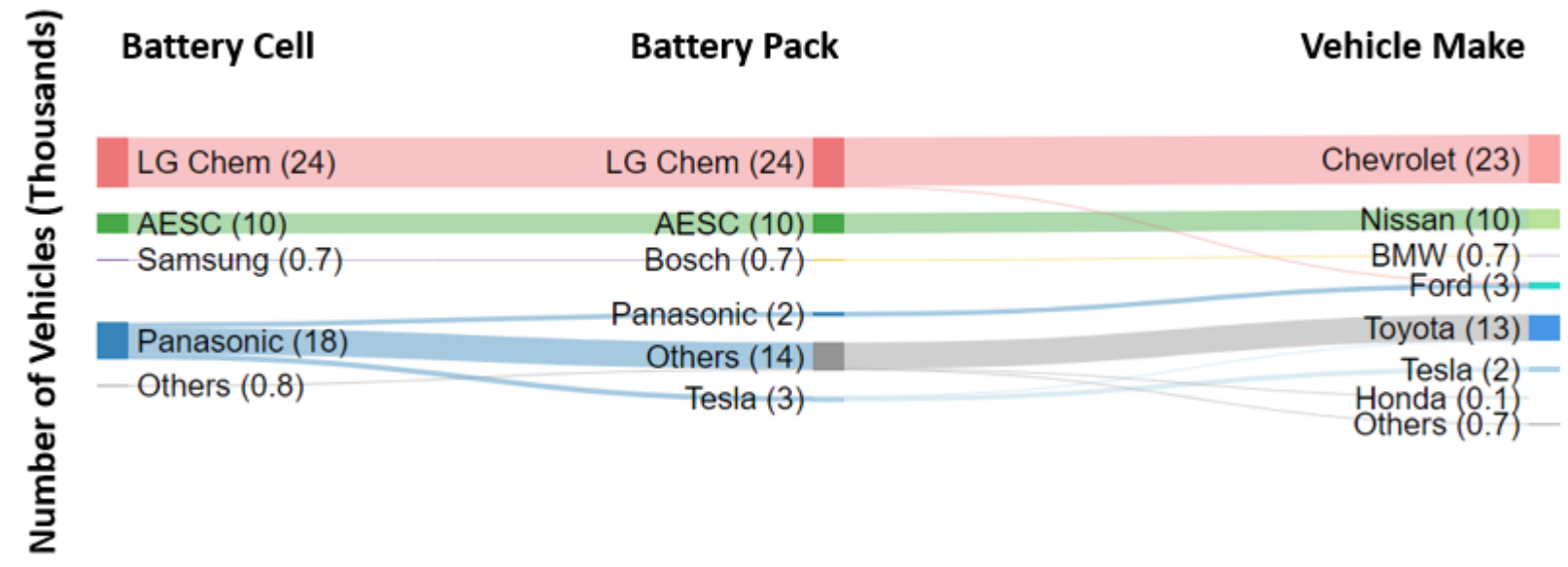

FIGURE A-12 2012 Number of battery packs (or vehicles) supplied to the U.S. PEV market by manufacturer. "Others" for battery cell includes Li-tec, GS Yuasa, and Toshiba; "Others" for battery pack includes Accumotive, GS Yuasa, Primearth EV Energy, and Toshiba. "Others" for vehicle makes includes Smart and Mitsubishi. 


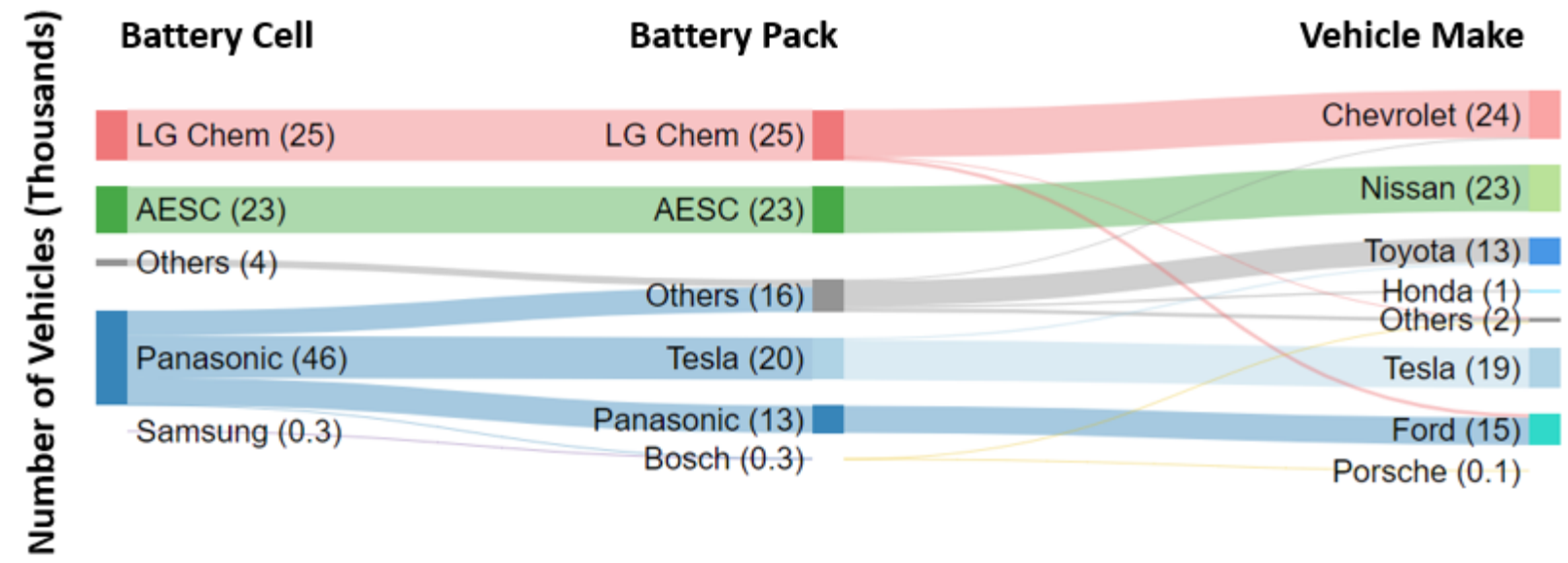

FIGURE A-13 2013 Number of battery packs (or vehicles) supplied to the U.S. PEV market by manufacturer. "Others" for battery cell includes Li-tec, GS Yuasa, Toshiba, Blue Energy, and A123; "Others" for battery pack includes Accumotive, GS Yuasa, Primearth EV Energy, Toshiba, Blue Energy, and A123. "Others" for vehicle makes includes Smart, Mitsubishi, Fiat, and Cadillac.

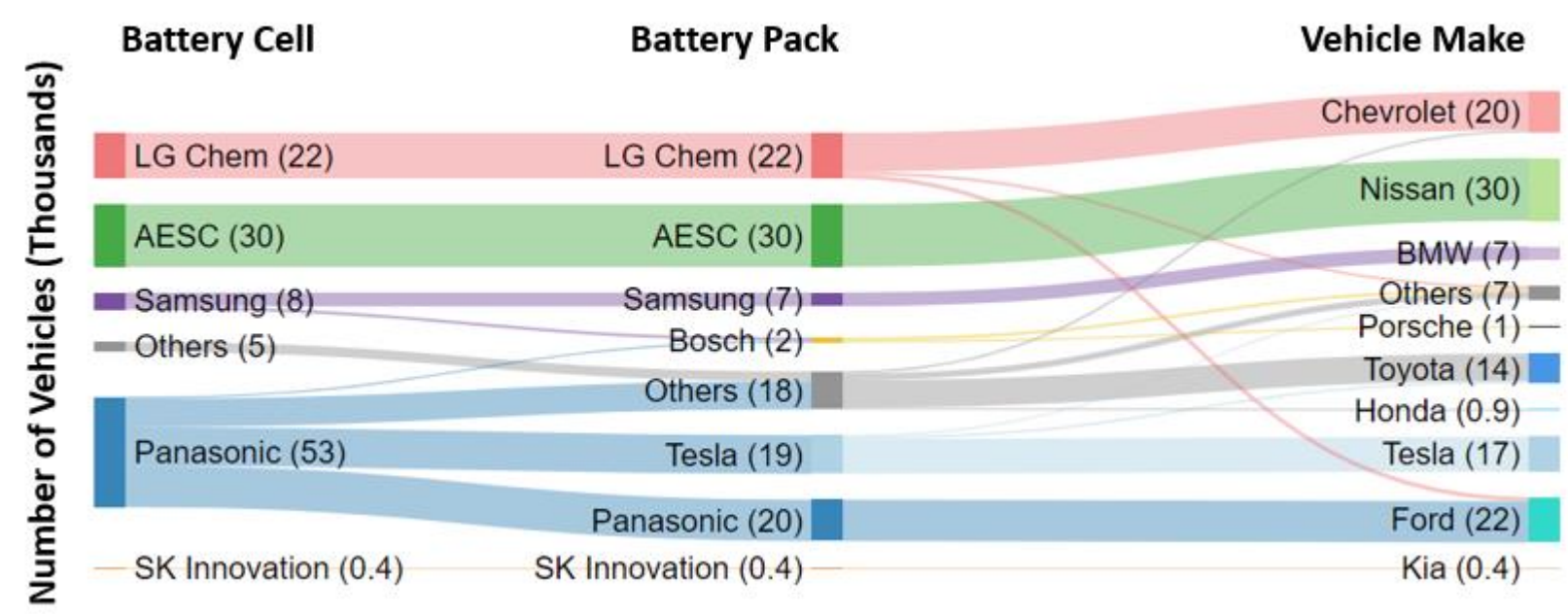

FIGURE A-14 2014 Number of battery packs (or vehicles) supplied to the U.S. PEV market by manufacturer. "Others" for battery cell includes Li-tec, GS Yuasa, Toshiba, Blue Energy, and A123; "Others" for battery pack includes Accumotive, GS Yuasa, Primearth EV Energy, Toshiba, Blue Energy, A123 and Sanyo. "Others" for vehicle makes includes Smart, Mitsubishi, Fiat, Cadillac, Mercedes, and Volkswagen. 


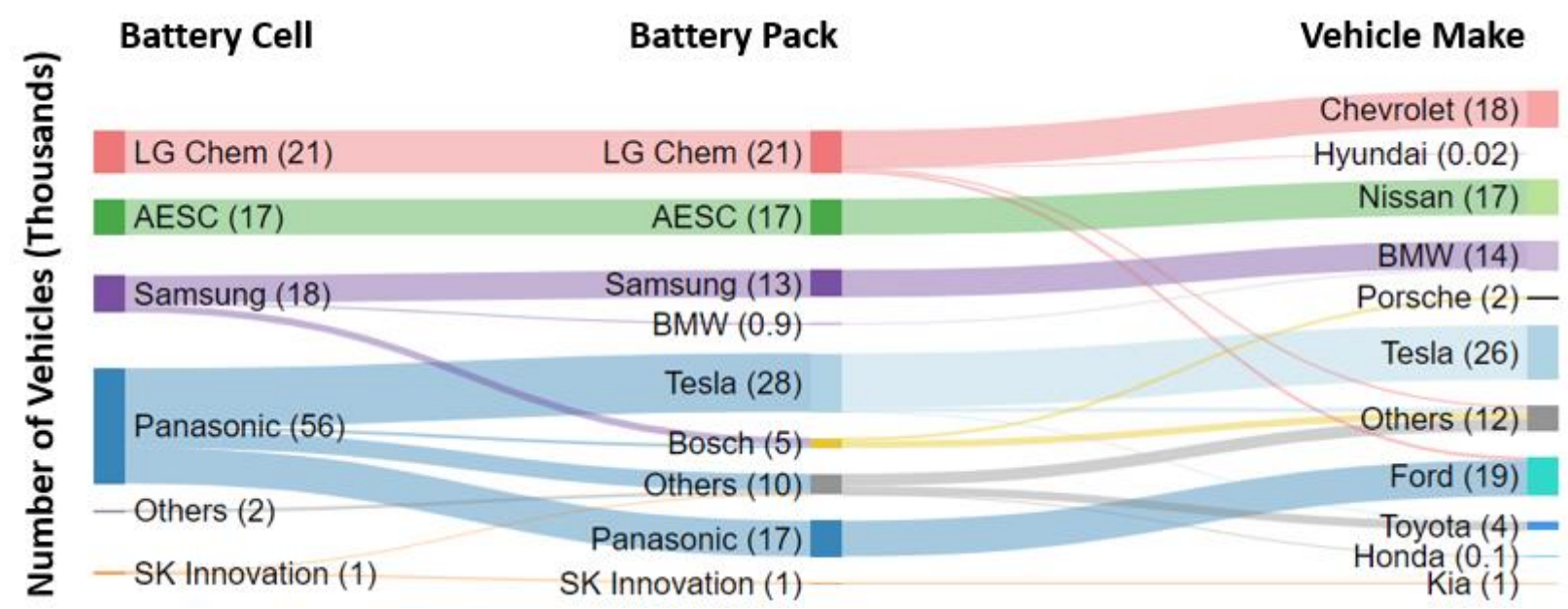

FIGURE A-15 2015 Number of battery packs (or vehicles) supplied to the U.S. PEV market by manufacturer. "Others" for battery cell includes Li-tec, GS Yuasa, Toshiba, and Blue Energy; “Others" for battery pack includes Accumotive, GS Yuasa, Primearth EV Energy, Toshiba, Blue Energy, and Sanyo. "Others" for vehicle makes includes Smart, Mitsubishi, Fiat, Cadillac, Mercedes, Volkswagen, and Volvo.

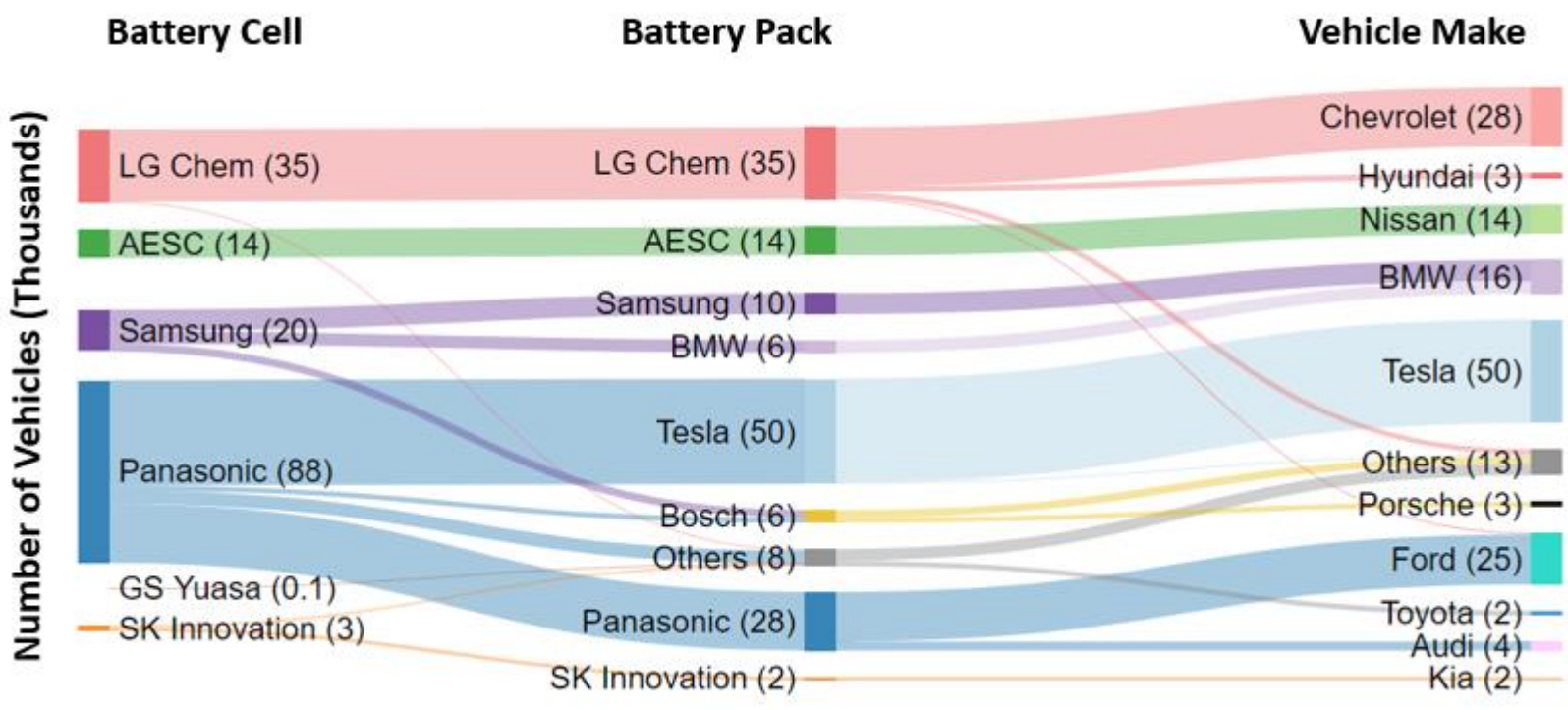

FIGURE A-16 2016 Number of battery packs (or vehicles) supplied to the U.S. PEV market by manufacturer. "Others" for battery pack includes Accumotive, GS Yuasa, Primearth EV Energy, and Sanyo. "Others" for vehicle makes includes Smart, Mitsubishi, Fiat, Cadillac, Mercedes, Volkswagen, and Volvo. 


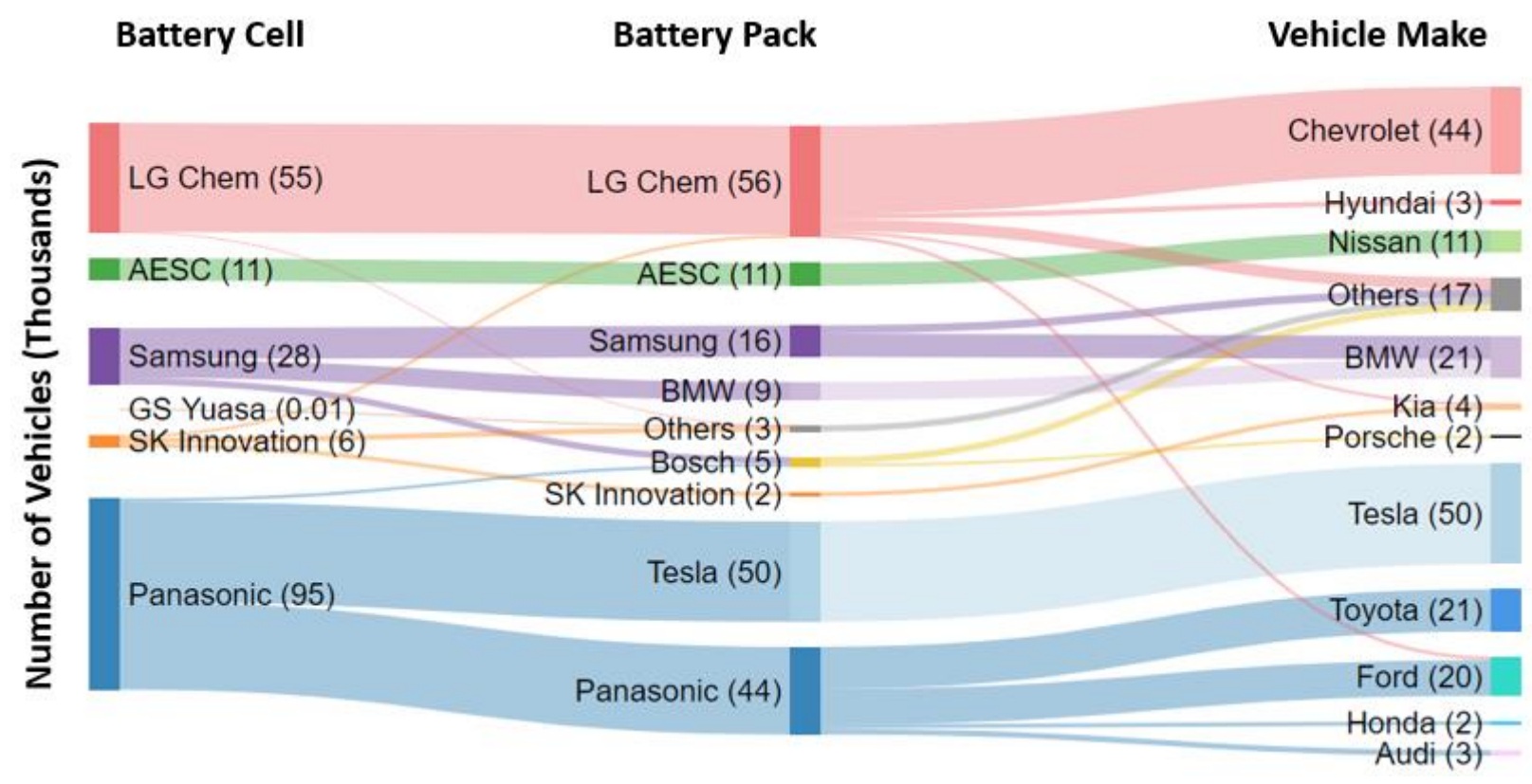

FIGURE A-17 2017 Number of battery packs (or vehicles) supplied to the U.S. PEV market by manufacturer. "Others" for battery pack includes Accumotive and GS Yuasa. "Others" for vehicle makes includes Smart, Mitsubishi, Fiat, Cadillac, Mercedes, Volkswagen, Volvo, Chrysler, and MINI. 


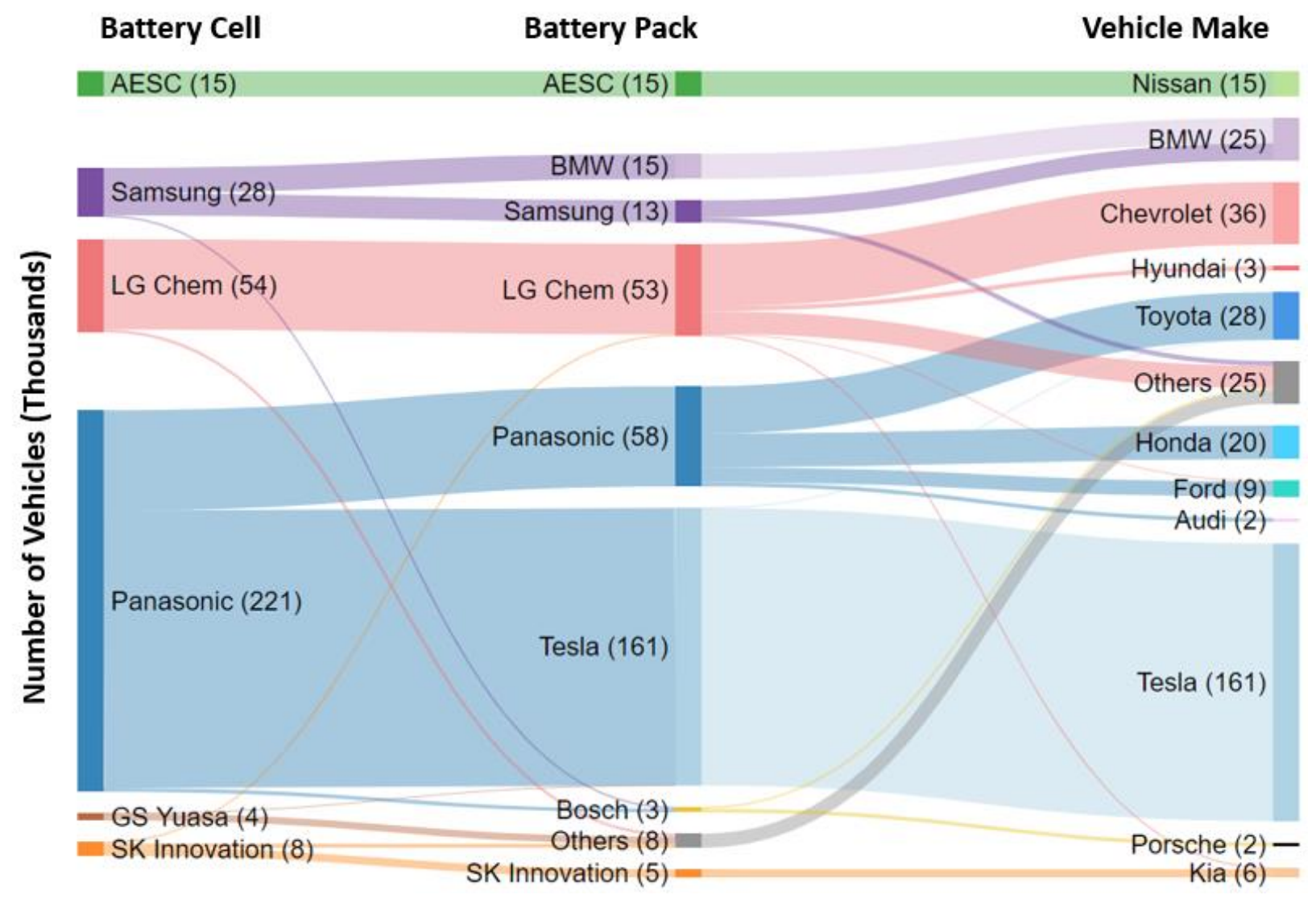

FIGURE A-18 2018 Number of battery packs (or vehicles) supplied to the U.S. PEV market by manufacturer. "Others" for battery pack includes Accumotive, GS Yuasa, and Jaguar. "Others" for vehicle makes includes Smart, Mitsubishi, Fiat, Cadillac, Mercedes, Volkswagen, Volvo, Chrysler, MINI, and Jaguar. 


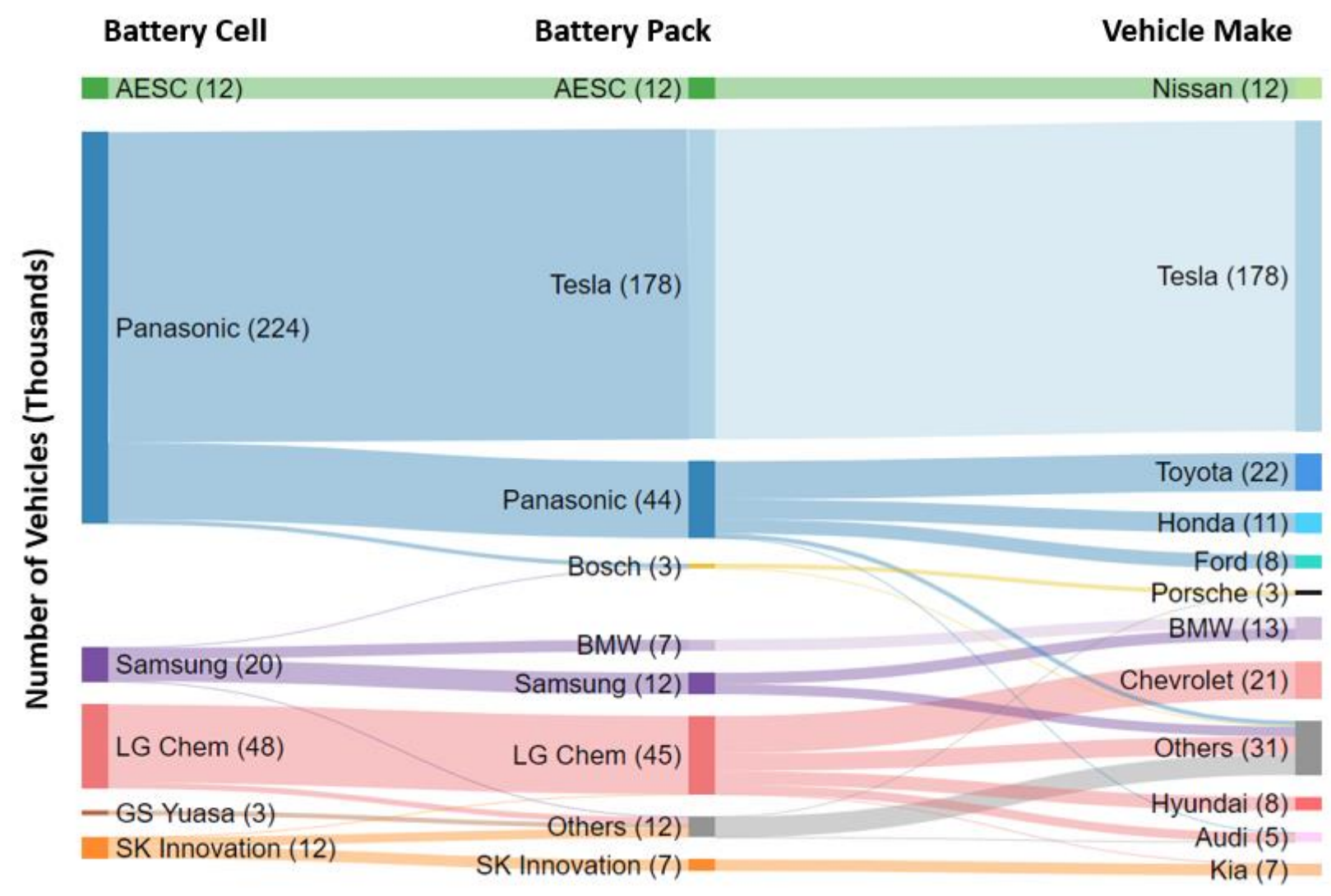

FIGURE A-19 2019 Number of battery packs (or vehicles) supplied to the U.S. PEV market by manufacturer. "Others" for battery pack includes Accumotive, GS Yuasa, Jaguar, and Draexlmaier. "Others" for vehicle makes includes Smart, Mitsubishi, Fiat, Cadillac, Mercedes, Volkswagen, Volvo, Chrysler, MINI, Jaguar, Subaru, Land Rover, and Lincoln. 


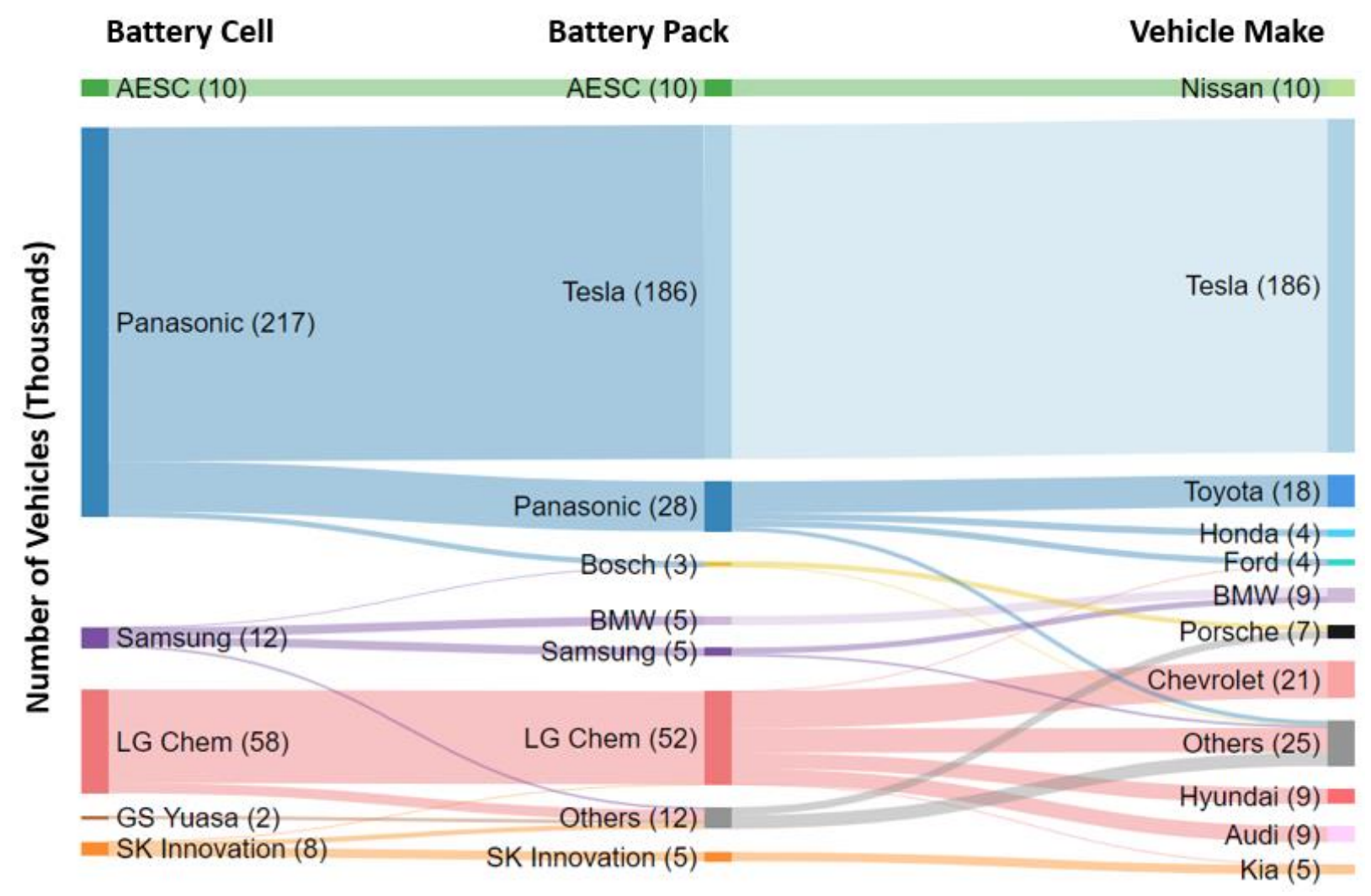

FIGURE A-20 2020 Number of battery packs (or vehicles) supplied to the U.S. PEV market by manufacturer. "Others" for battery pack includes Accumotive, GS Yuasa, Jaguar, and Draexlmaier. "Others" for vehicle makes includes Mitsubishi, Fiat, Cadillac, Mercedes, Volkswagen, Volvo, Chrysler, MINI, Jaguar, Subaru, Land Rover, Lincoln, Polestar, and Jeep.

Figures A-21 to A-30 show battery capacity supplied to the U.S. PEV market by production location. Note that the following annual diagrams for battery capacity by country are on the same scale: one unit corresponds to the same height in each figure. Also note that the values are measured in MWh. 


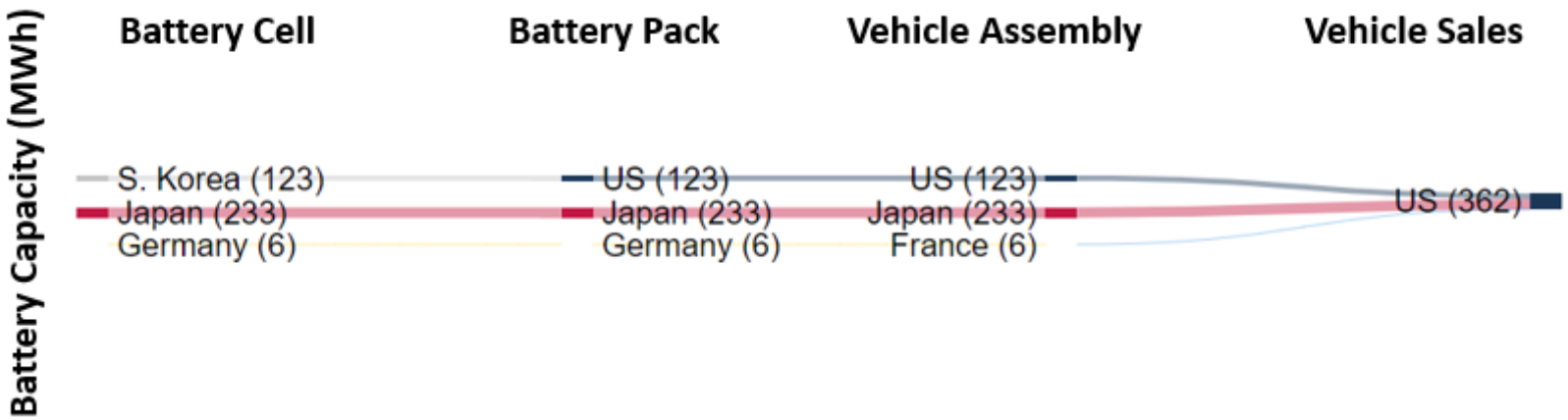

FIGURE A-21 2011 Total capacity (MWh) of Li-ion batteries supplied to the U.S. PEV market by production location.

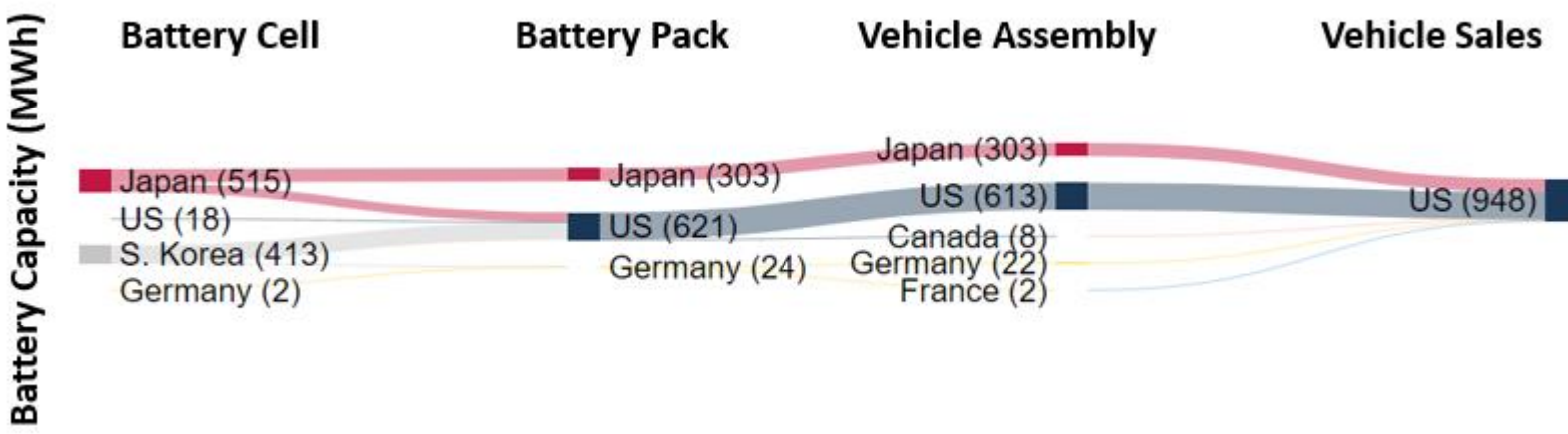

FIGURE A-22 2012 Total capacity (MWh) of Li-ion batteries supplied to the U.S. PEV market by production location.

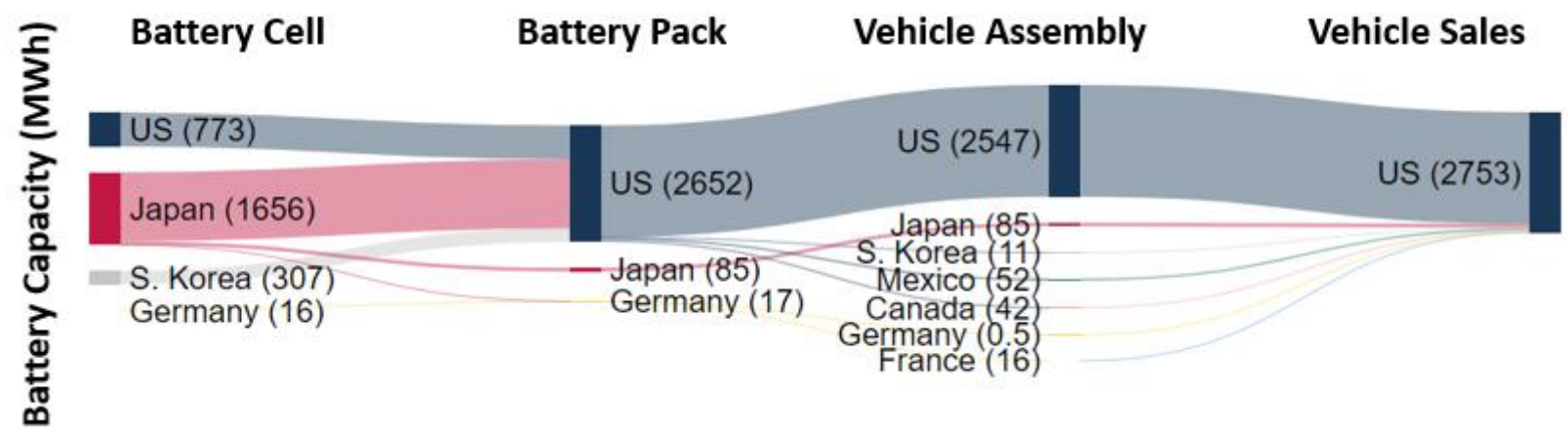

FIGURE A-23 2013 Total capacity (MWh) of Li-ion batteries supplied to the U.S. PEV market by production location. 


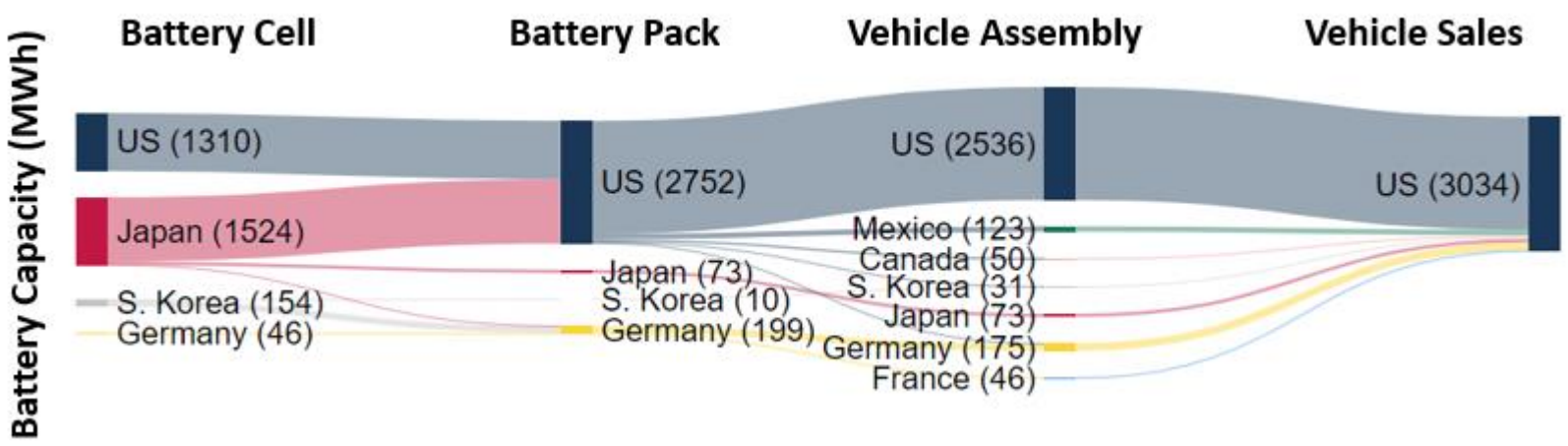

FIGURE A-24 2014 Total capacity (MWh) of Li-ion batteries supplied to the U.S. PEV market by production location.

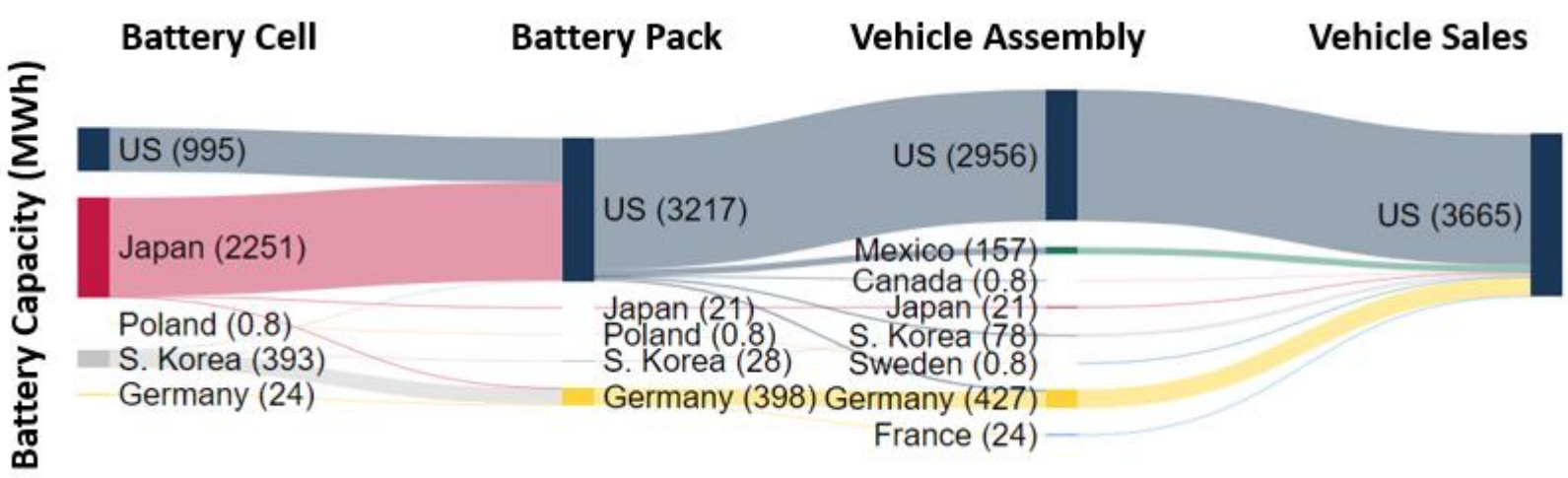

FIGURE A-25 2015 Total capacity (MWh) of Li-ion batteries supplied to the U.S. PEV market by production location.

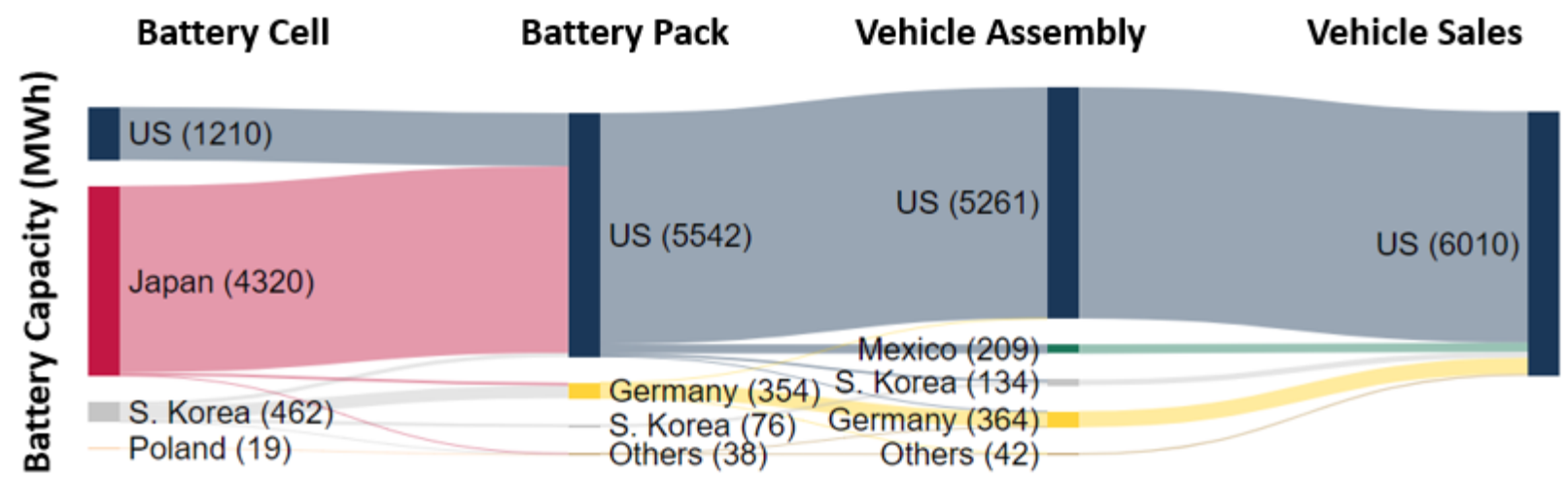

FIGURE A-26 2016 Total capacity (MWh) of Li-ion batteries supplied to the U.S. PEV market by production location. "Others" for battery pack includes Japan, Poland, and Hungary; "Others" for vehicle assembly includes France, Japan, and Sweden. 


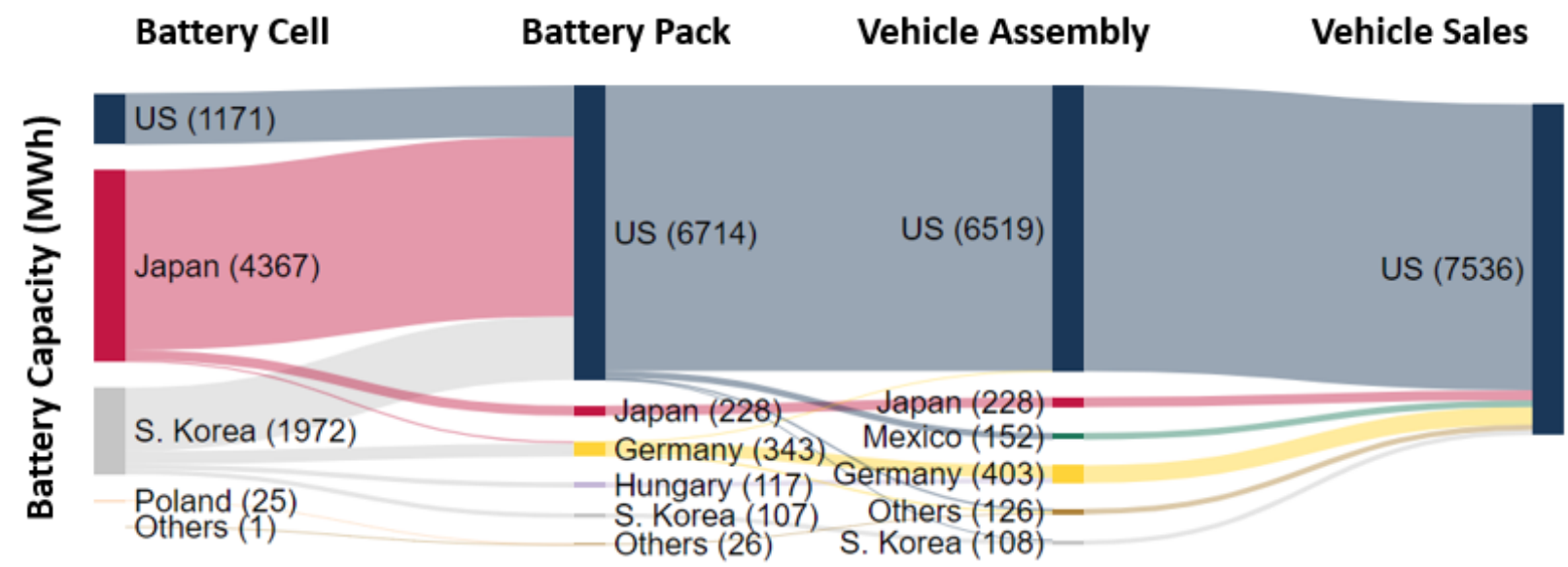

FIGURE A-27 2017 Total capacity (MWh) of Li-ion batteries supplied to the U.S. PEV market by production location. “Others" for battery pack includes Poland and China; "Others" for vehicle assembly includes France, Sweden, Canada, China, Austria, and Netherlands.

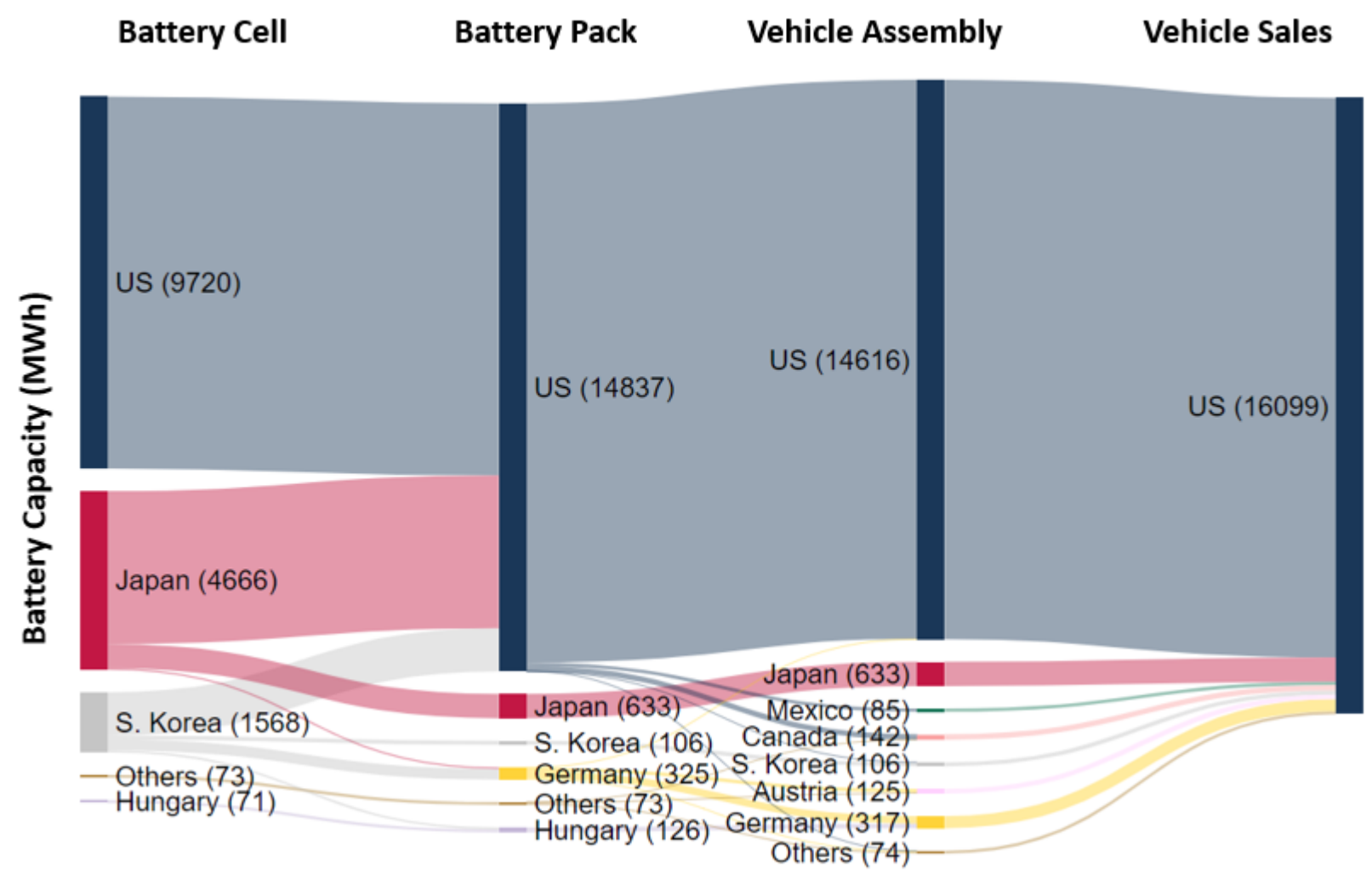

FIGURE A-28 2018 Total capacity (MWh) of Li-ion batteries supplied to the U.S. PEV market by production location. "Others" for battery cell includes Poland and China; "Others" for battery pack includes Poland and China; "Others" for vehicle assembly includes France, Sweden, China, and Netherlands. 


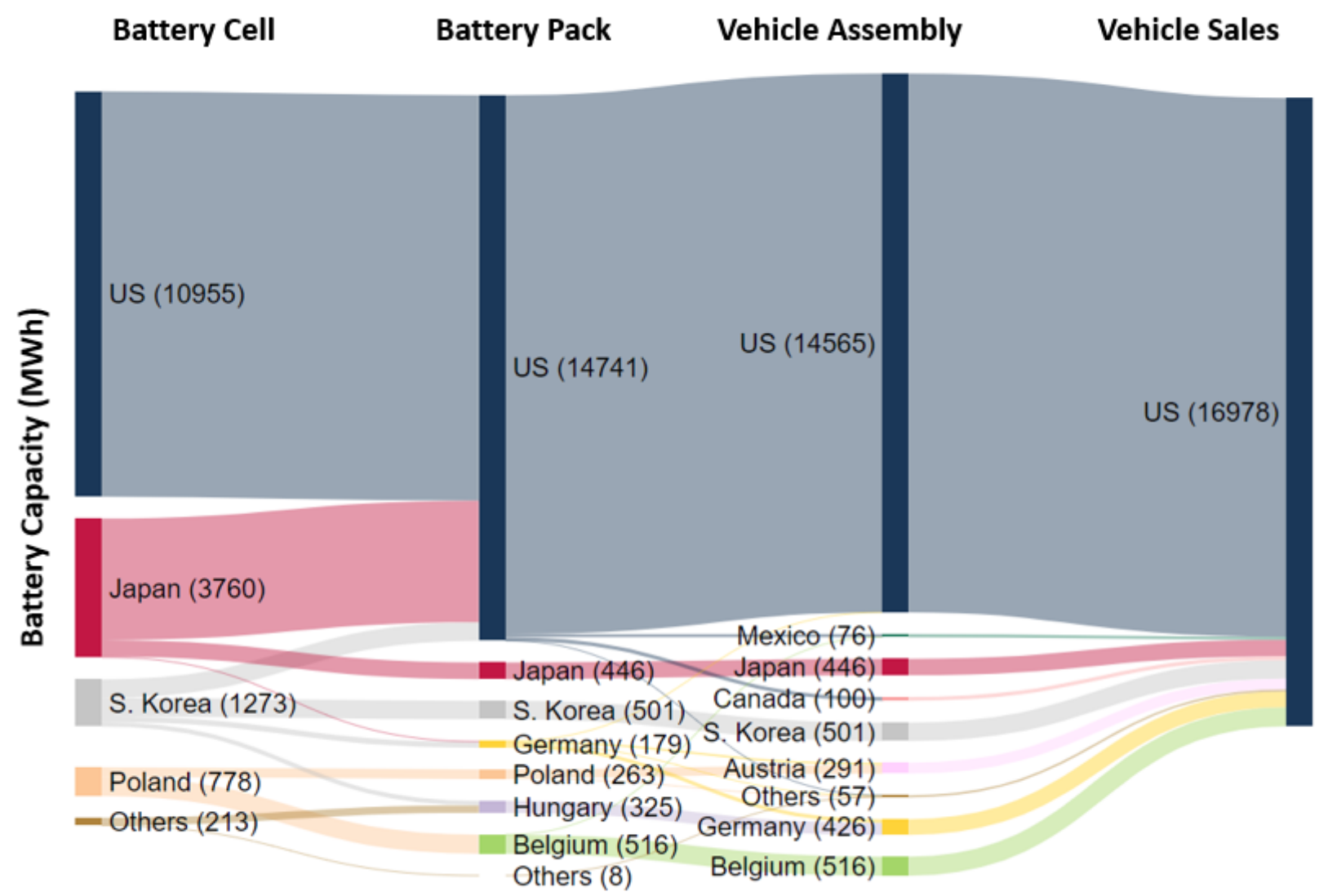

FIGURE A-29 2019 Total capacity (MWh) of Li-ion batteries supplied to the U.S. PEV market by production location. "Others" for battery cell includes China and Hungary; "Others" for battery pack includes China and U.K.; "Others" for vehicle assembly includes France, Sweden, China, Netherlands, and United Kingdom. 


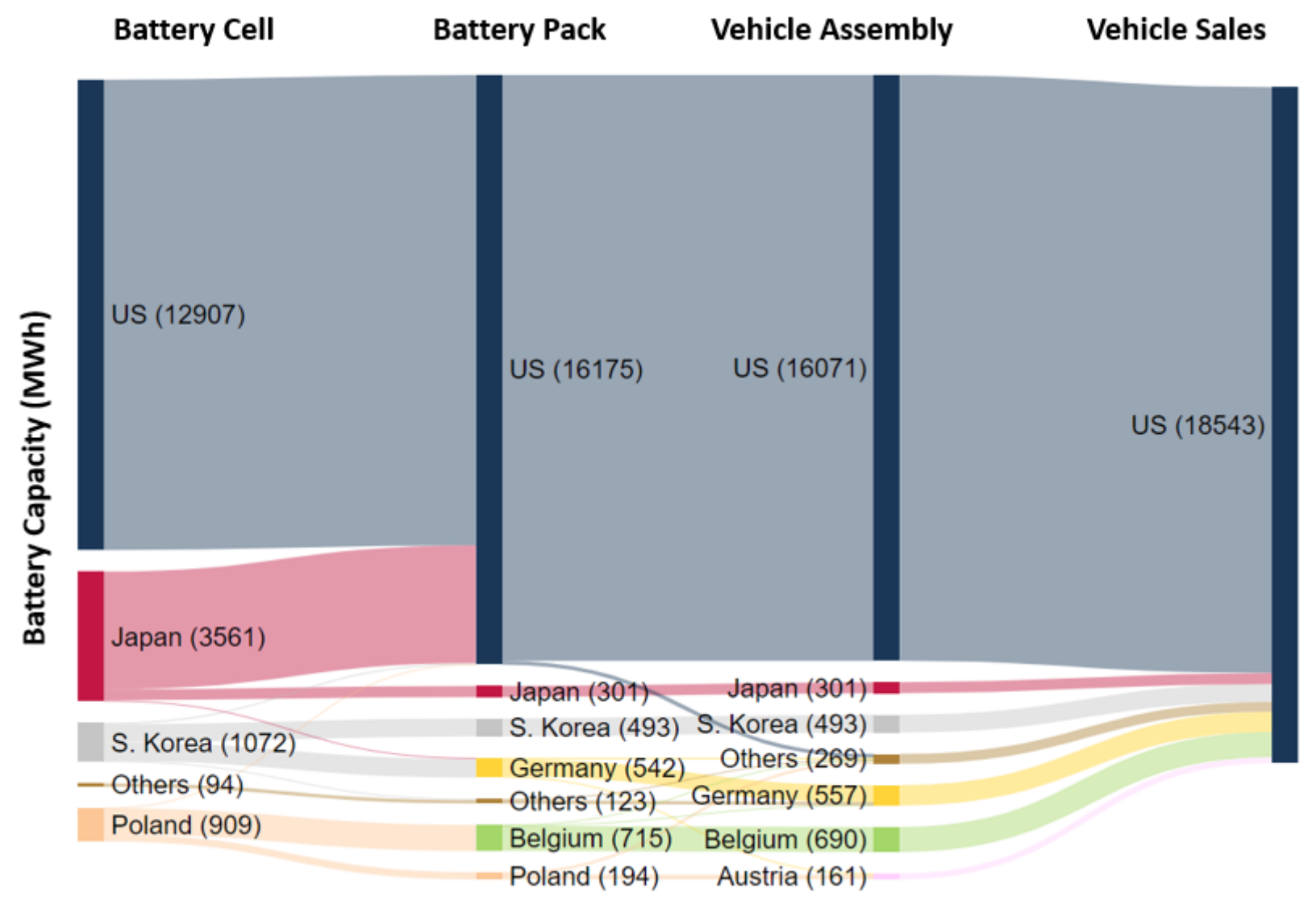

FIGURE A-30 2020 Total capacity (MWh) of Li-ion batteries supplied to the U.S. PEV market by production location. "Others" for battery cell includes China and Hungary; "Others" for battery pack includes Hungary, China, and United Kingdom; "Others" for vehicle assembly includes Sweden, China, Netherlands, Mexico, Slovakia, Canada, and United Kingdom.

Figures A-31 to A-40 show the number of battery packs (or vehicles) supplied to the U.S. PEV market by production location. Note that the following annual diagrams for battery packs/vehicle units by country are on the same scale: one unit corresponds to the same height in each figure. Also note that the values are measured in thousands of units. 


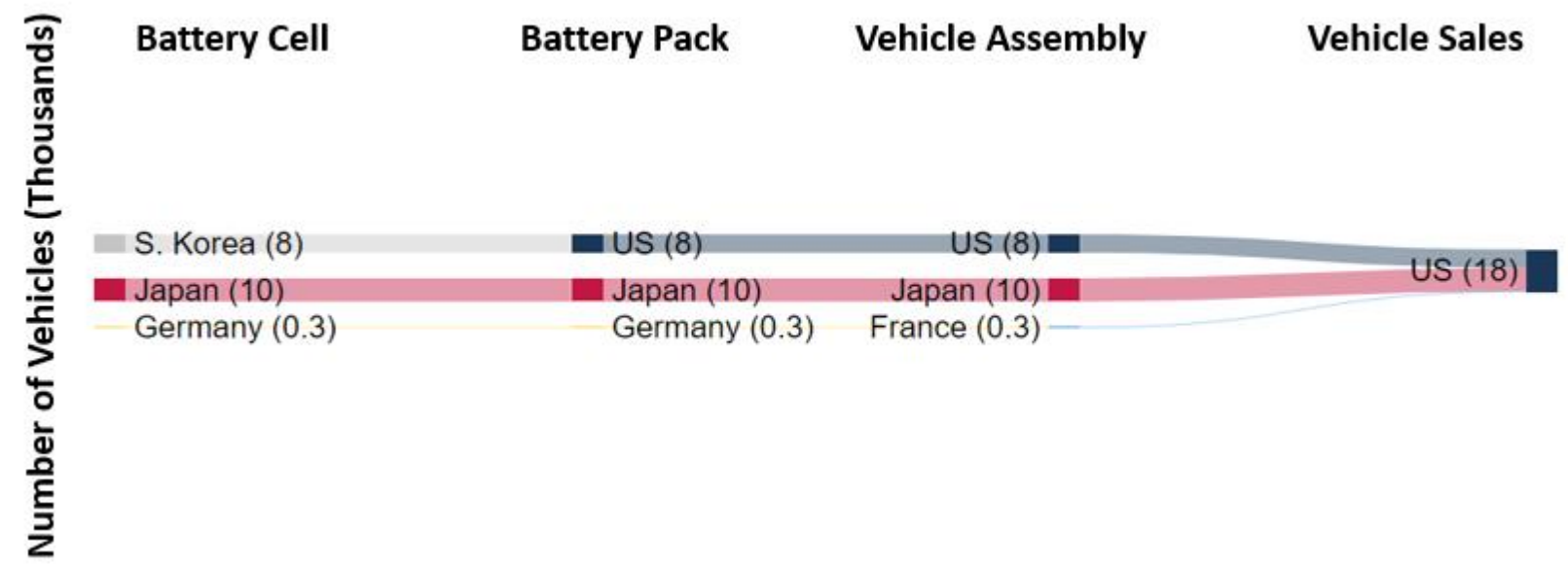

FIGURE A-31 2011 Number of battery packs (or vehicles) supplied to the U.S. PEV market by production location.

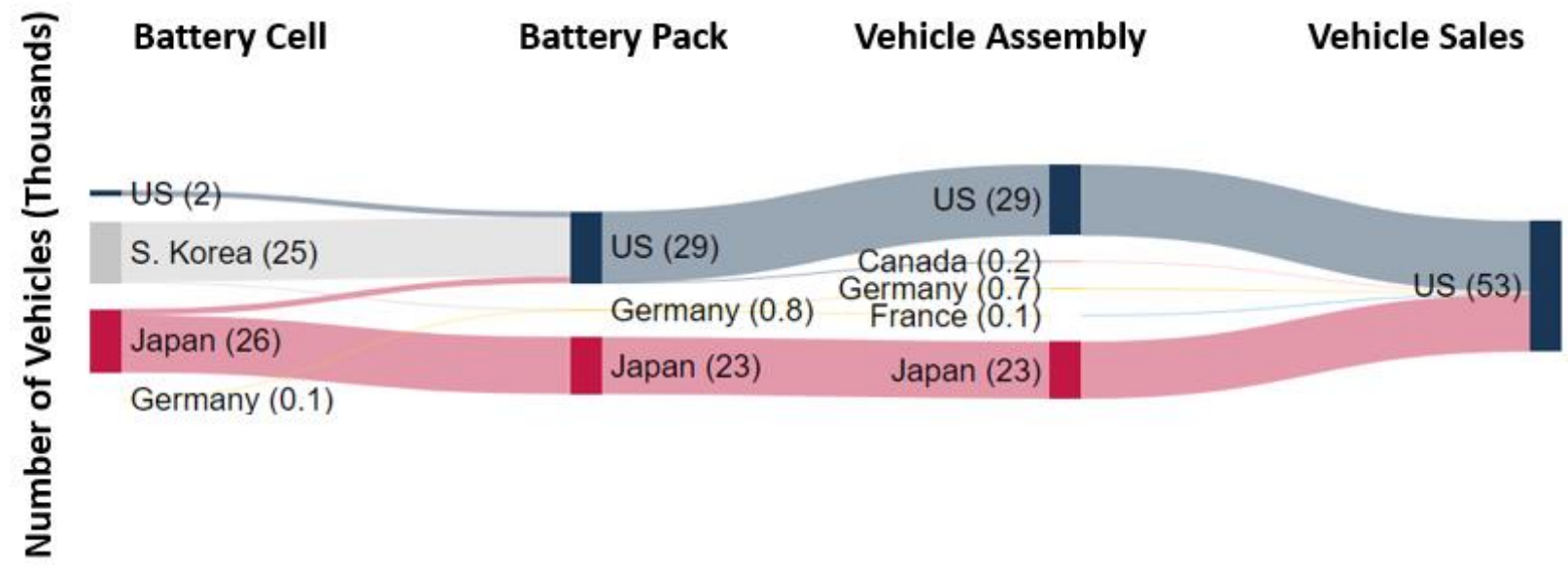

FIGURE A-32 2012 Number of battery packs (or vehicles) supplied to the U.S. PEV market by production location. 


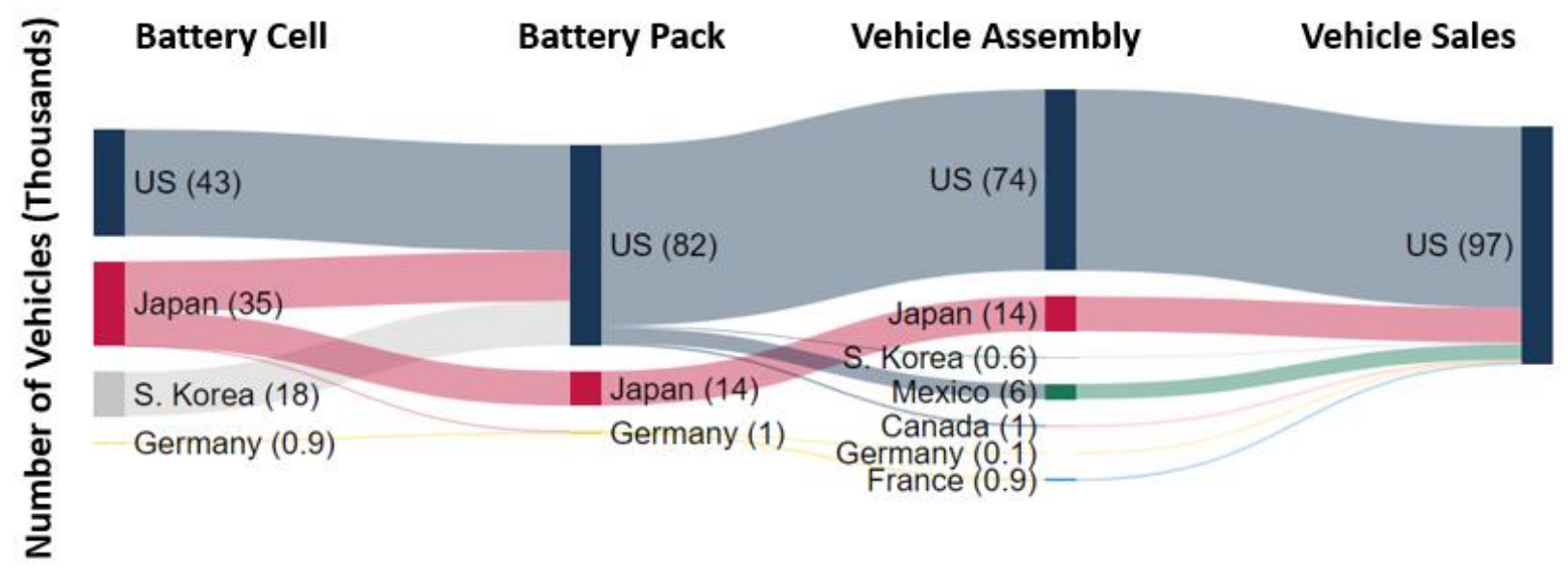

FIGURE A-33 2013 Number of battery packs (or vehicles) supplied to the U.S. PEV market by production location.

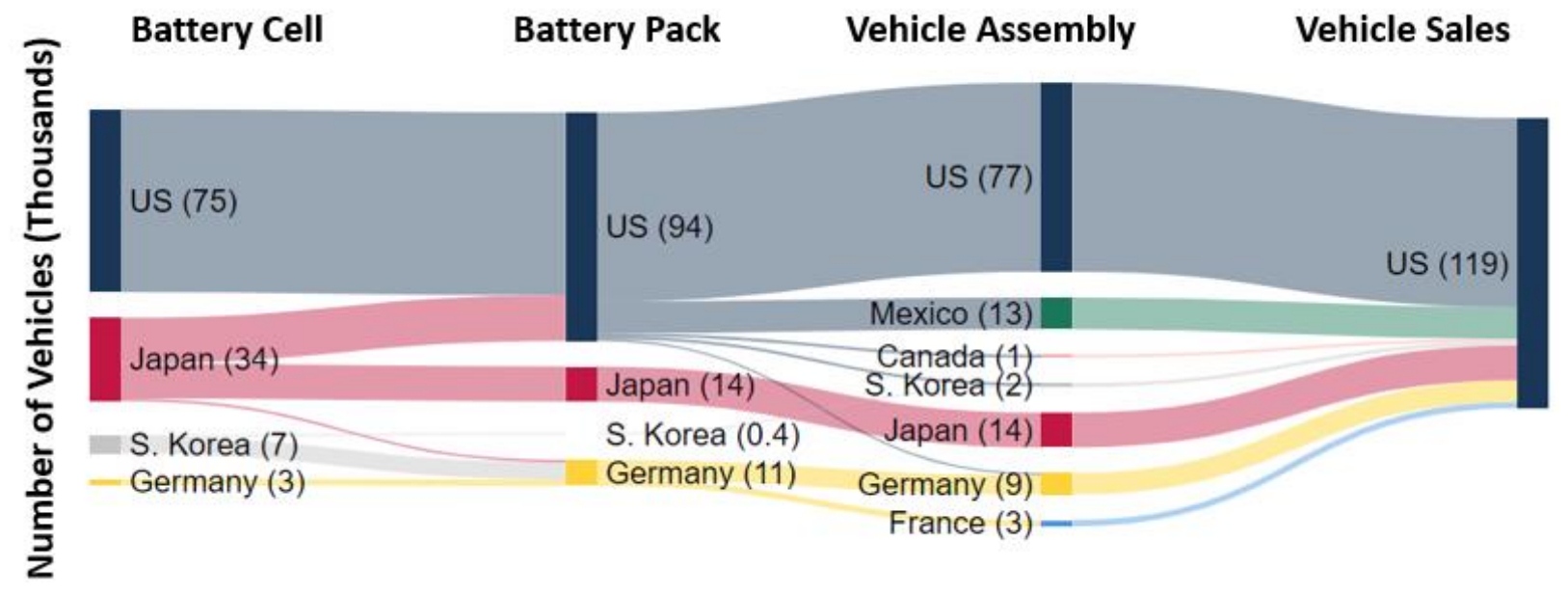

FIGURE A-34 2014 Number of battery packs (or vehicles) supplied to the U.S. PEV market by production location. 


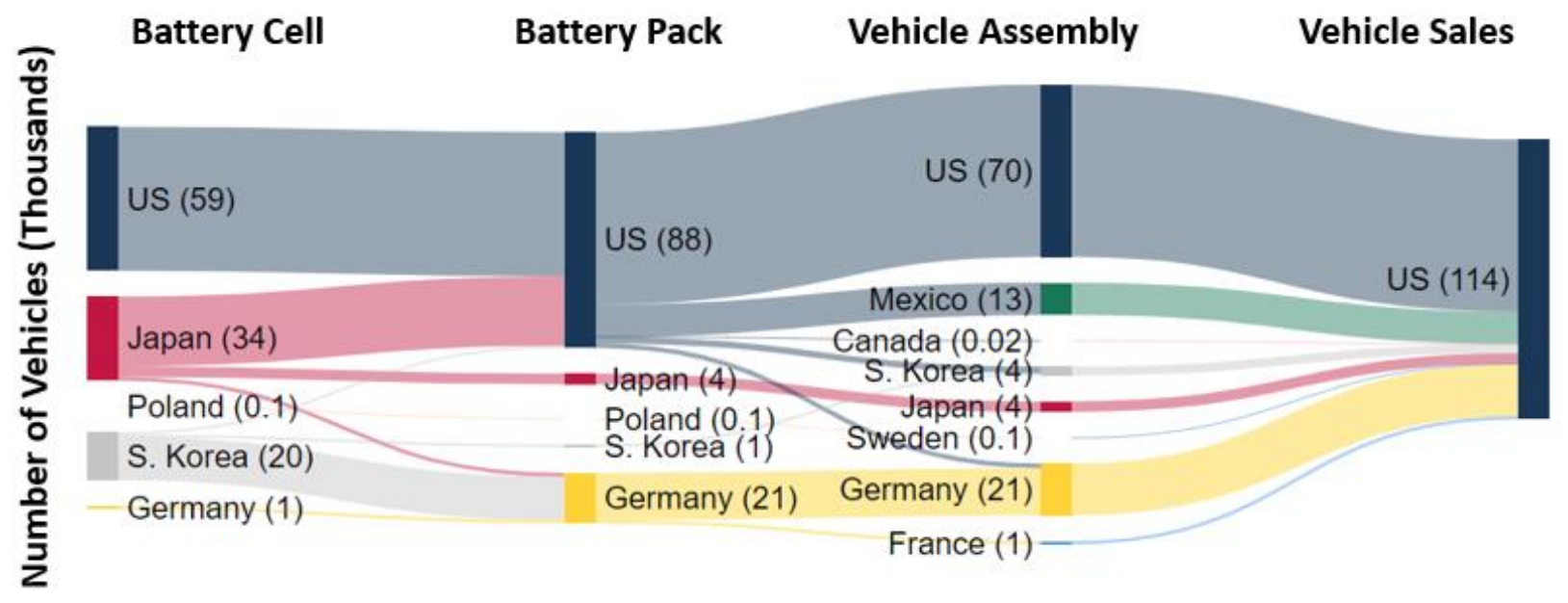

FIGURE A-35 2015 Number of battery packs (or vehicles) supplied to the U.S. PEV market by production location.

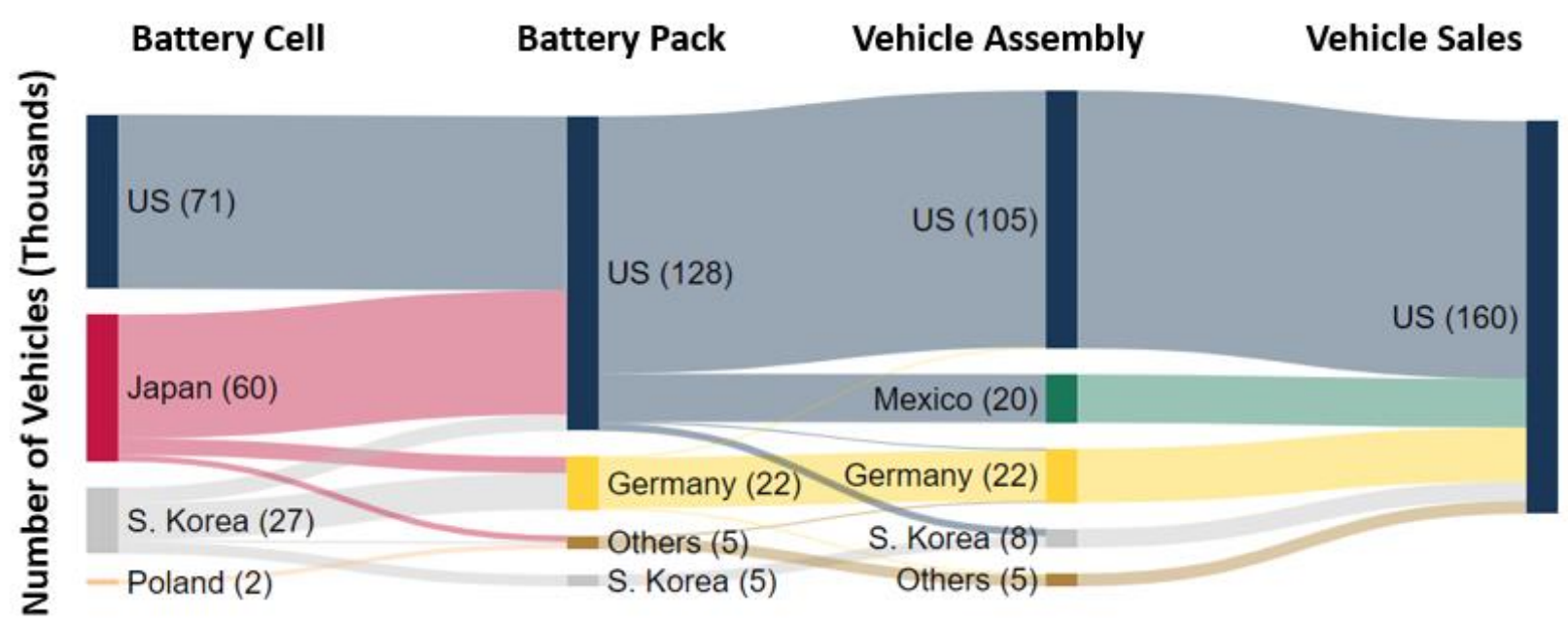

FIGURE A-36 2016 Number of battery packs (or vehicles) supplied to the U.S. PEV market by production location. "Others" for battery pack includes Japan, Poland, and Hungary; "Others" for vehicle assembly includes France, Japan, and Sweden. 


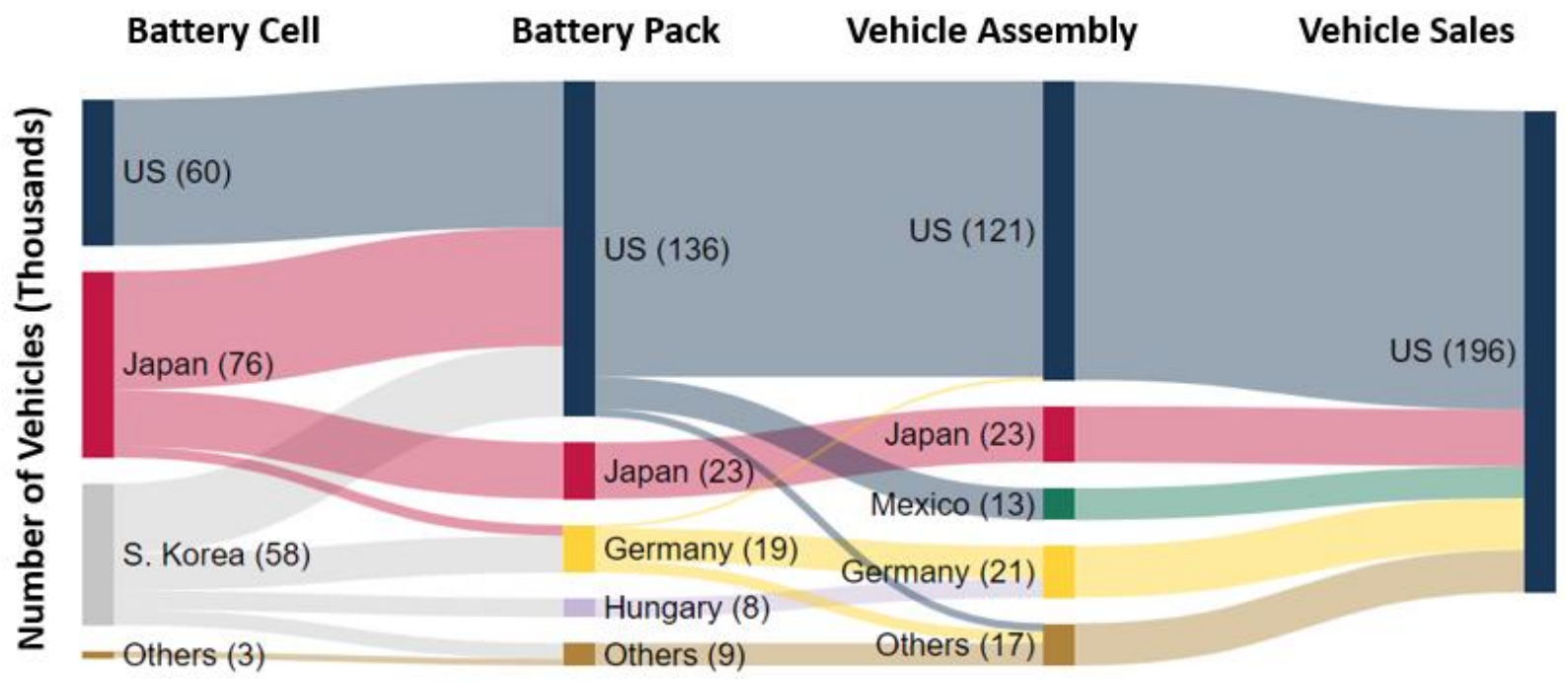

FIGURE A-37 2017 Number of battery packs (or vehicles) supplied to the U.S. PEV market by production location. "Others" for battery cell includes Poland and China; "Others" for battery pack includes S. Korea, Poland and China; "Others" for vehicle assembly includes France, S. Korea, Sweden, Canada, China, Austria, and Netherlands.

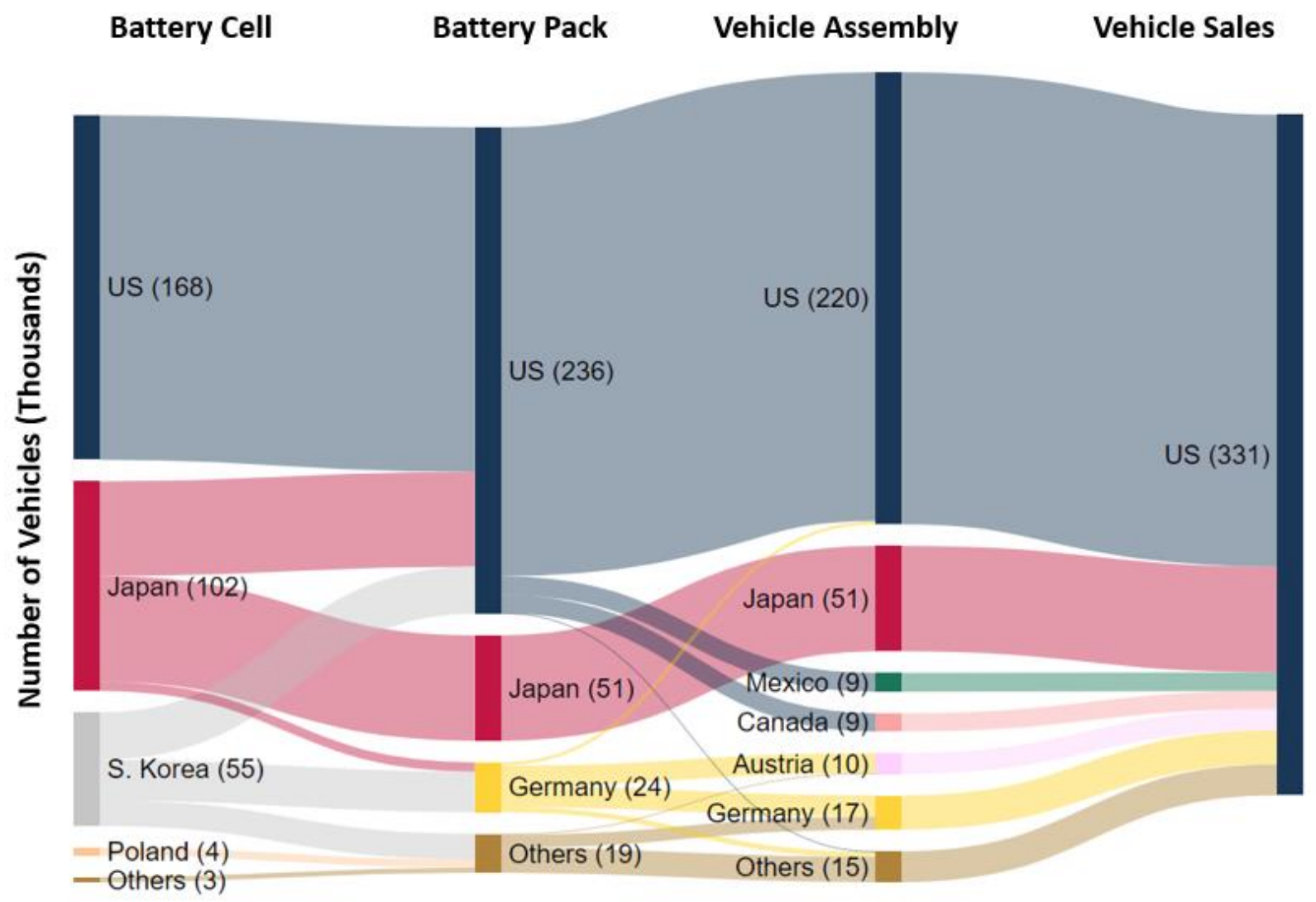

FIGURE A-38 2018 Number of battery packs (or vehicles) supplied to the U.S. PEV market by production location. "Others" for battery cell includes China and Hungary; "Others" for battery pack includes Poland, Hungary, S. Korea, and China; "Others" for vehicle assembly includes France, S. Korea, Sweden, China, and Netherlands. 


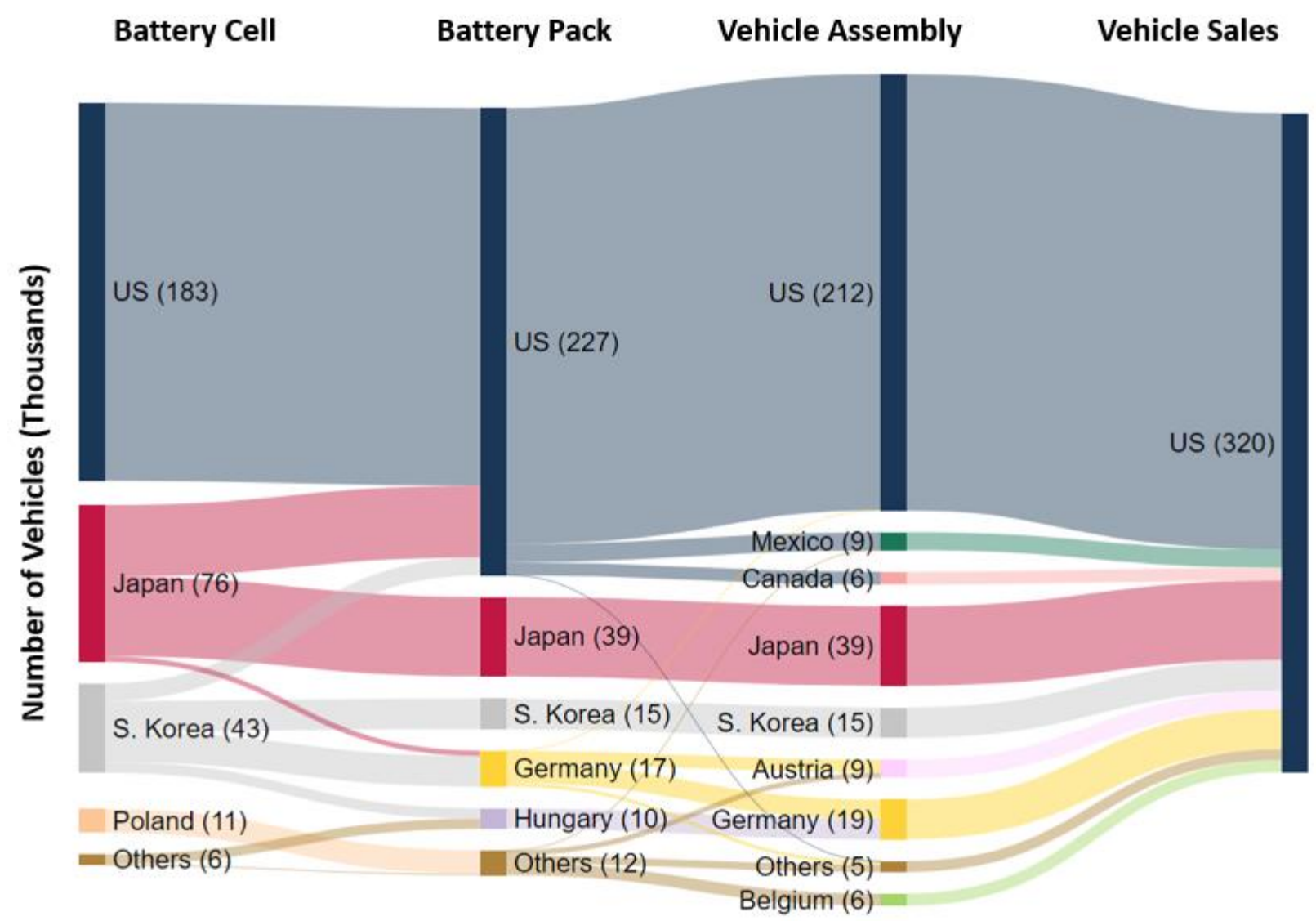

FIGURE A-39 2019 Number of battery packs (or vehicles) supplied to the U.S. PEV market by production location. "Others" for battery cell includes China and Hungary; "Others" for battery pack includes Poland, China, Belgium, and United Kingdom; "Others" for vehicle assembly includes France, Sweden, China, Netherlands, and United Kingdom. 


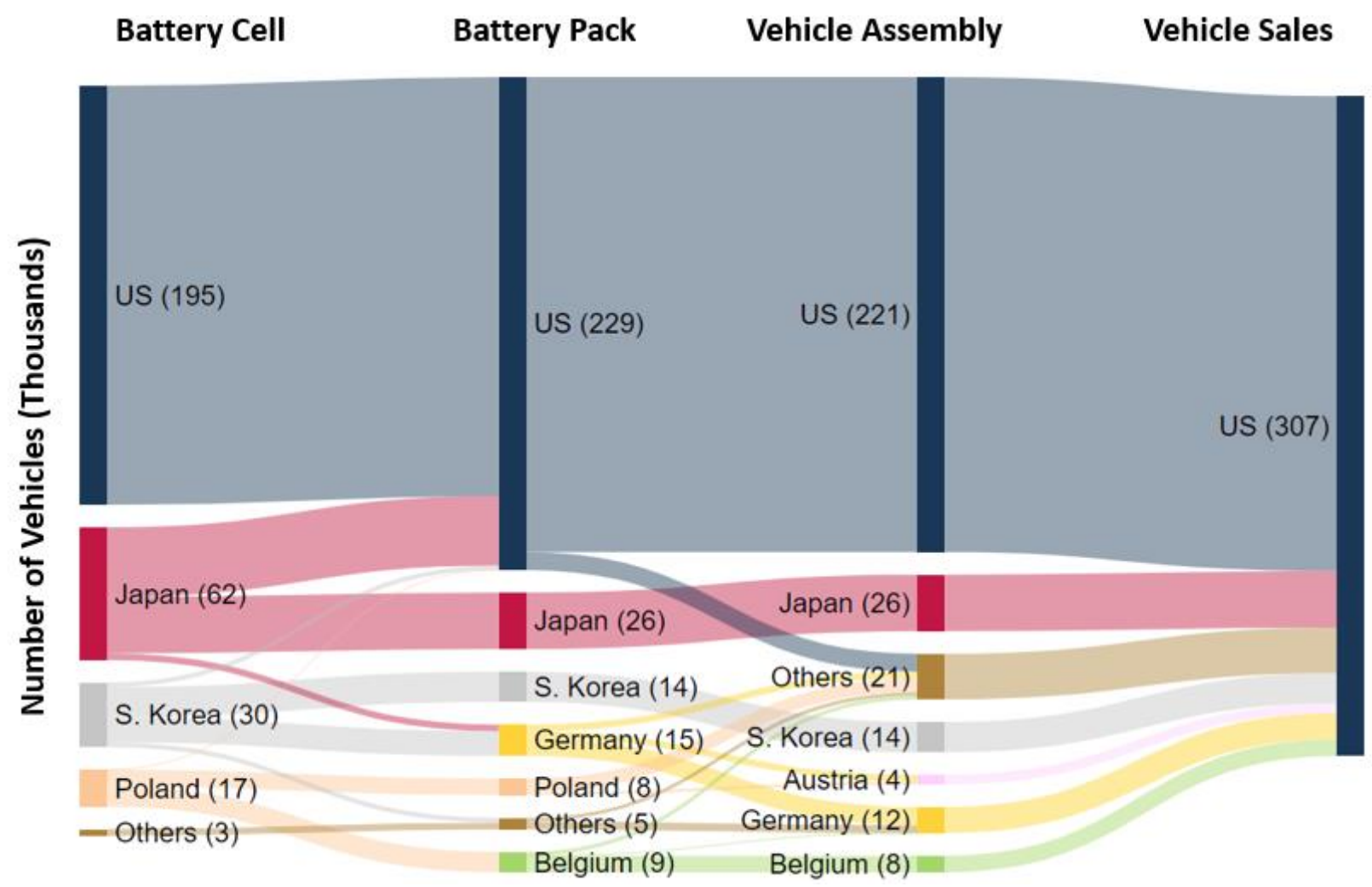

FIGURE A-40 2020 Number of battery packs (or vehicles) supplied to the U.S. PEV market by production location. "Others" for battery cell includes Hungary and China; "Others" for battery pack includes Hungary, China, and United Kingdom; "Others" for vehicle assembly includes Sweden, China, Netherlands, Mexico, Slovakia, Canada, and United Kingdom.

Figures A-41 through A-50 show battery capacity for battery cell, battery pack, vehicle assembly, vehicle sale, by location, only BEVs. Note that the following annual diagrams for battery capacity by country are on the same scale: one unit corresponds to the same height in each figure. Also note that the values are measured in MWh.

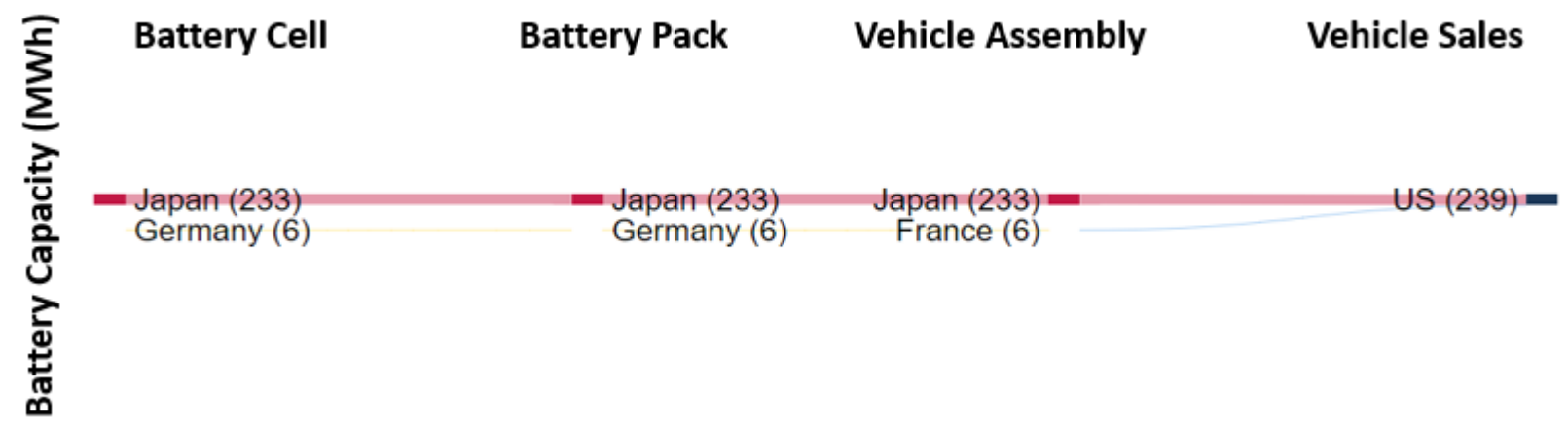

FIGURE A-41 2011 Total capacity (MWh) of Li-ion batteries supplied to the U.S. BEV market by production location. 


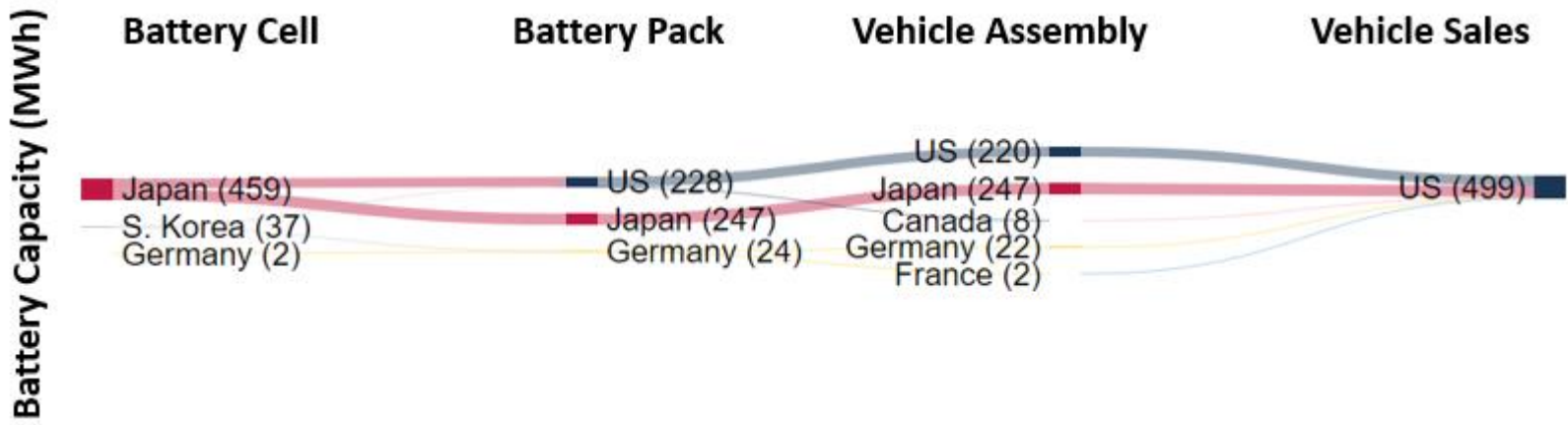

FIGURE A-42 2012 Total capacity (MWh) of Li-ion batteries supplied to the U.S. BEV market by production location.

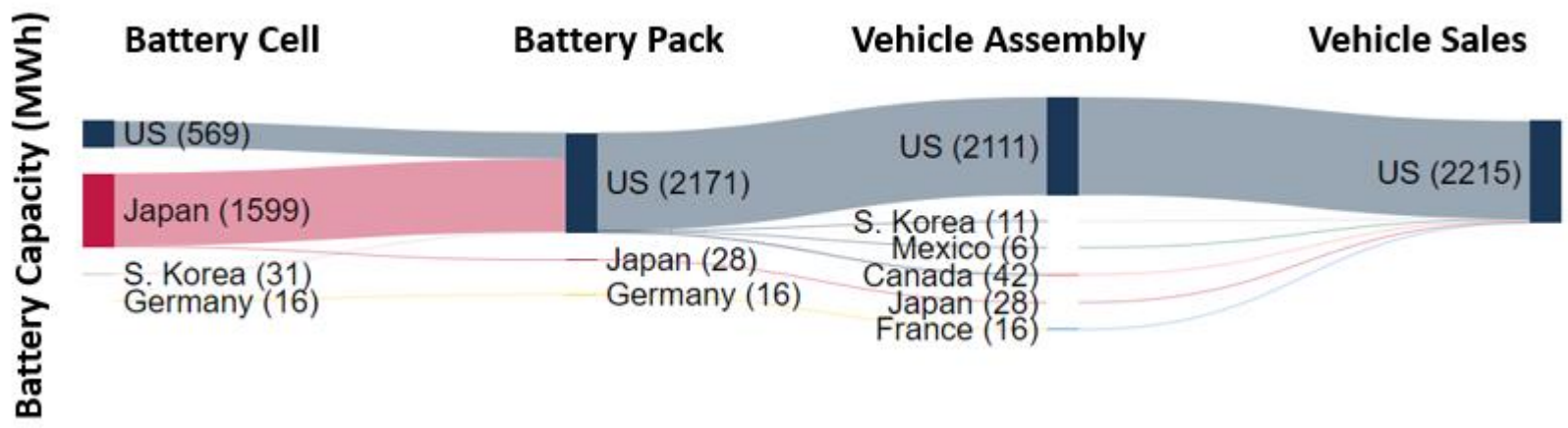

FIGURE A-43 2013 Total capacity (MWh) of Li-ion batteries supplied to the U.S. BEV market by production location.

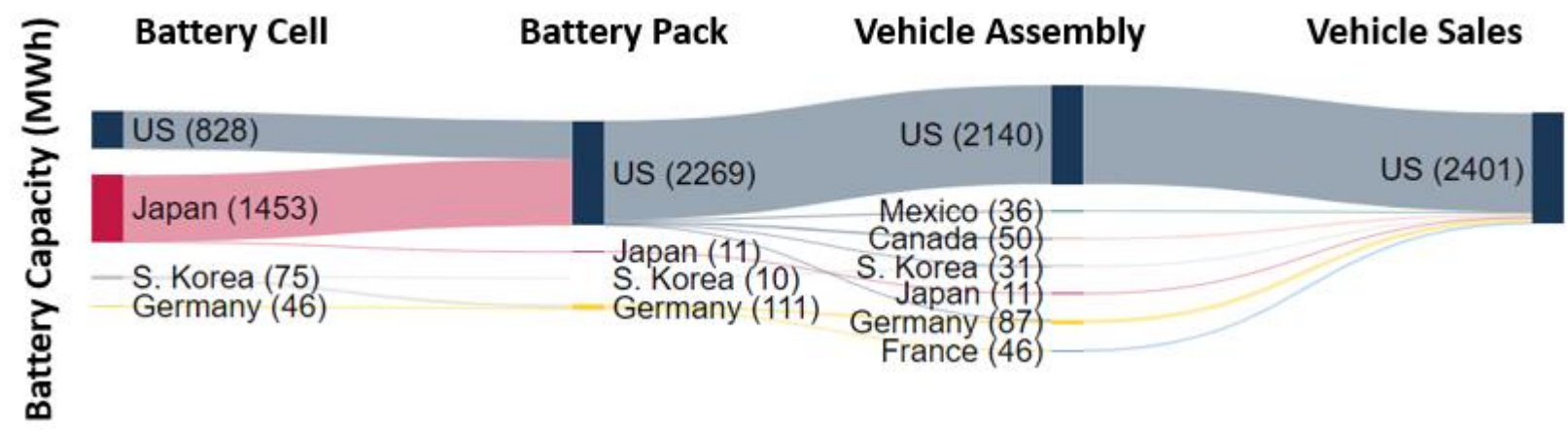

FIGURE A-44 2014 Total capacity (MWh) of Li-ion batteries supplied to the U.S. BEV market by production location. 


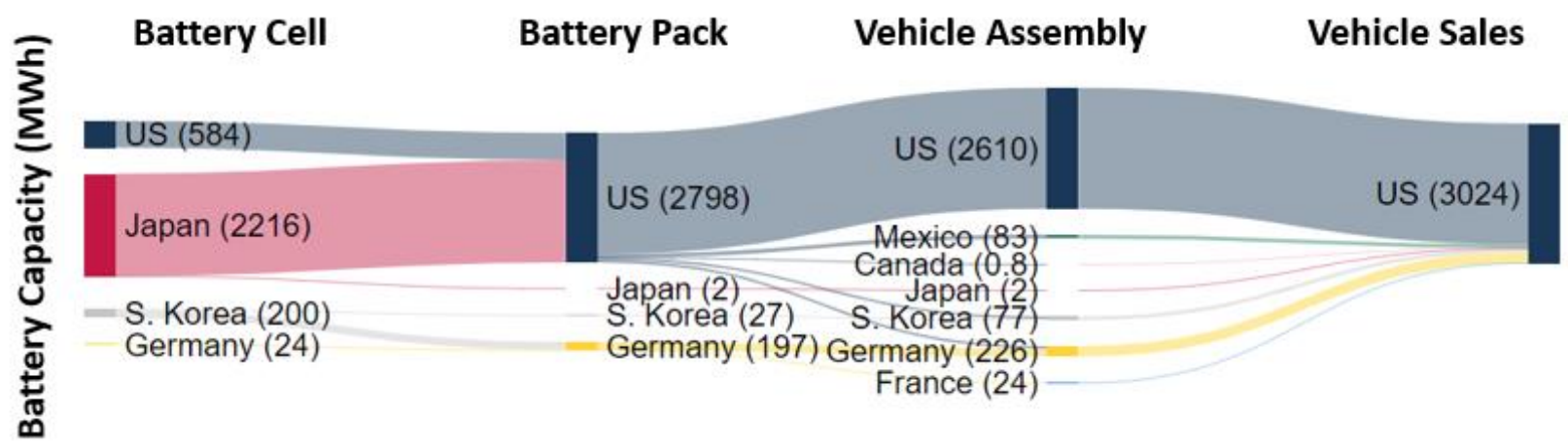

FIGURE A-45 2015 Total capacity (MWh) of Li-ion batteries supplied to the U.S. BEV market by production location.

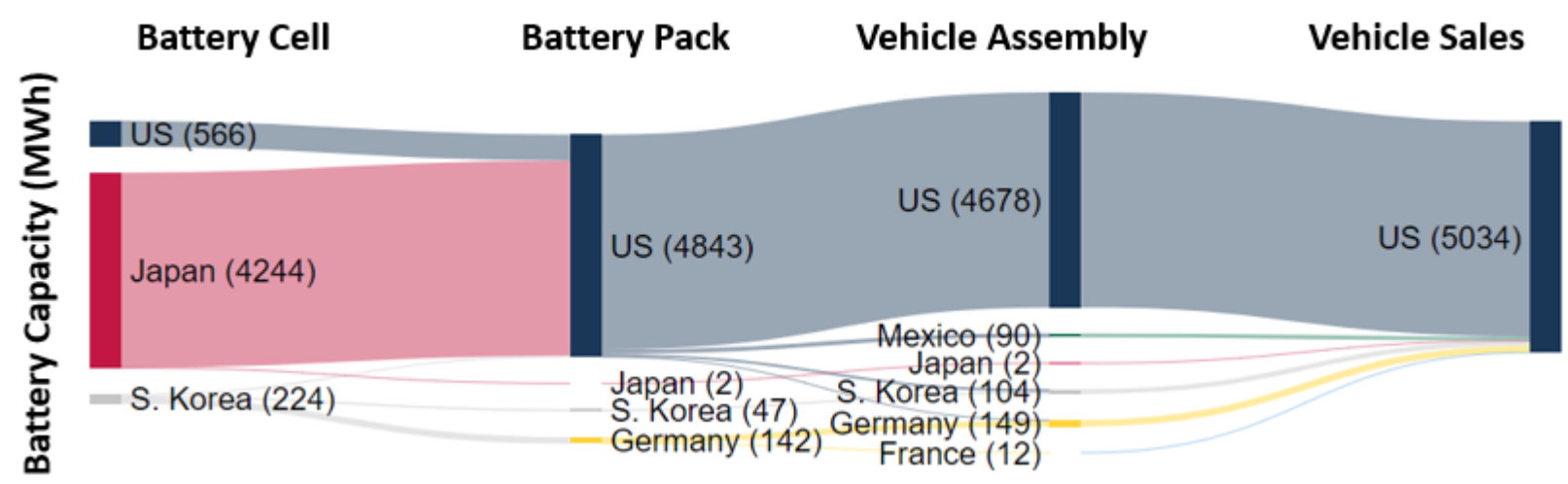

FIGURE A-46 2016 Total capacity (MWh) of Li-ion batteries supplied to the U.S. BEV market by production location.

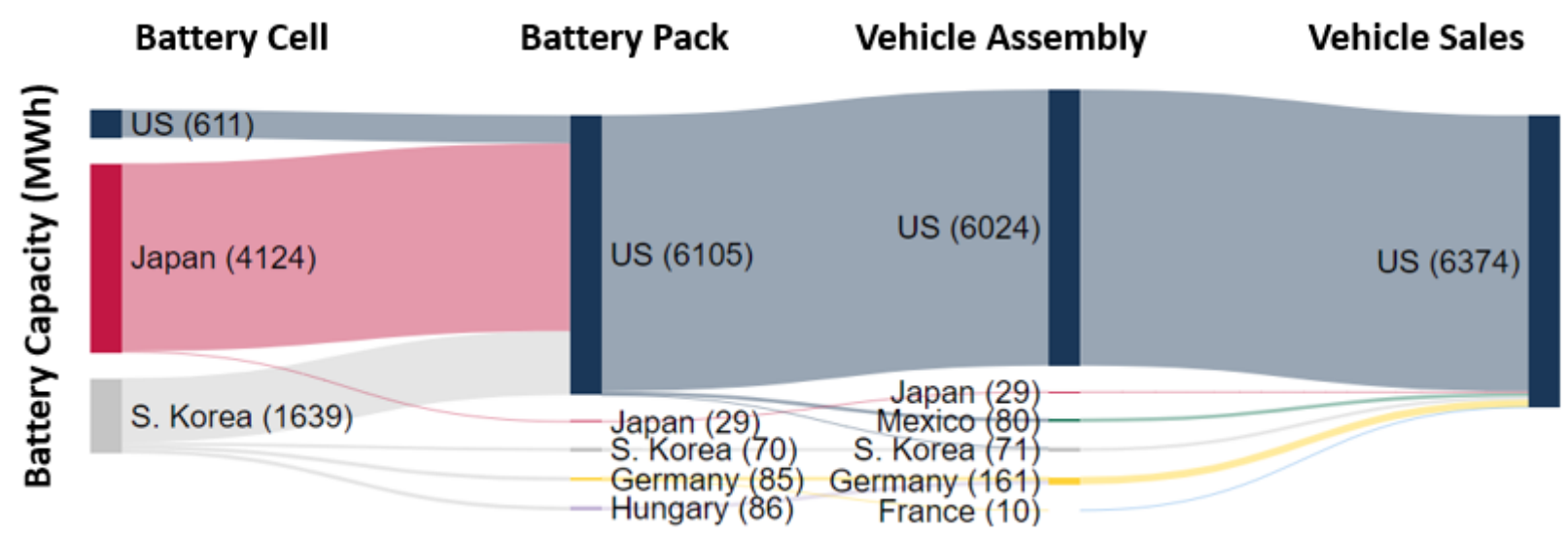

FIGURE A-47 2017 Total capacity (MWh) of Li-ion batteries supplied to the U.S. BEV market by production location. 


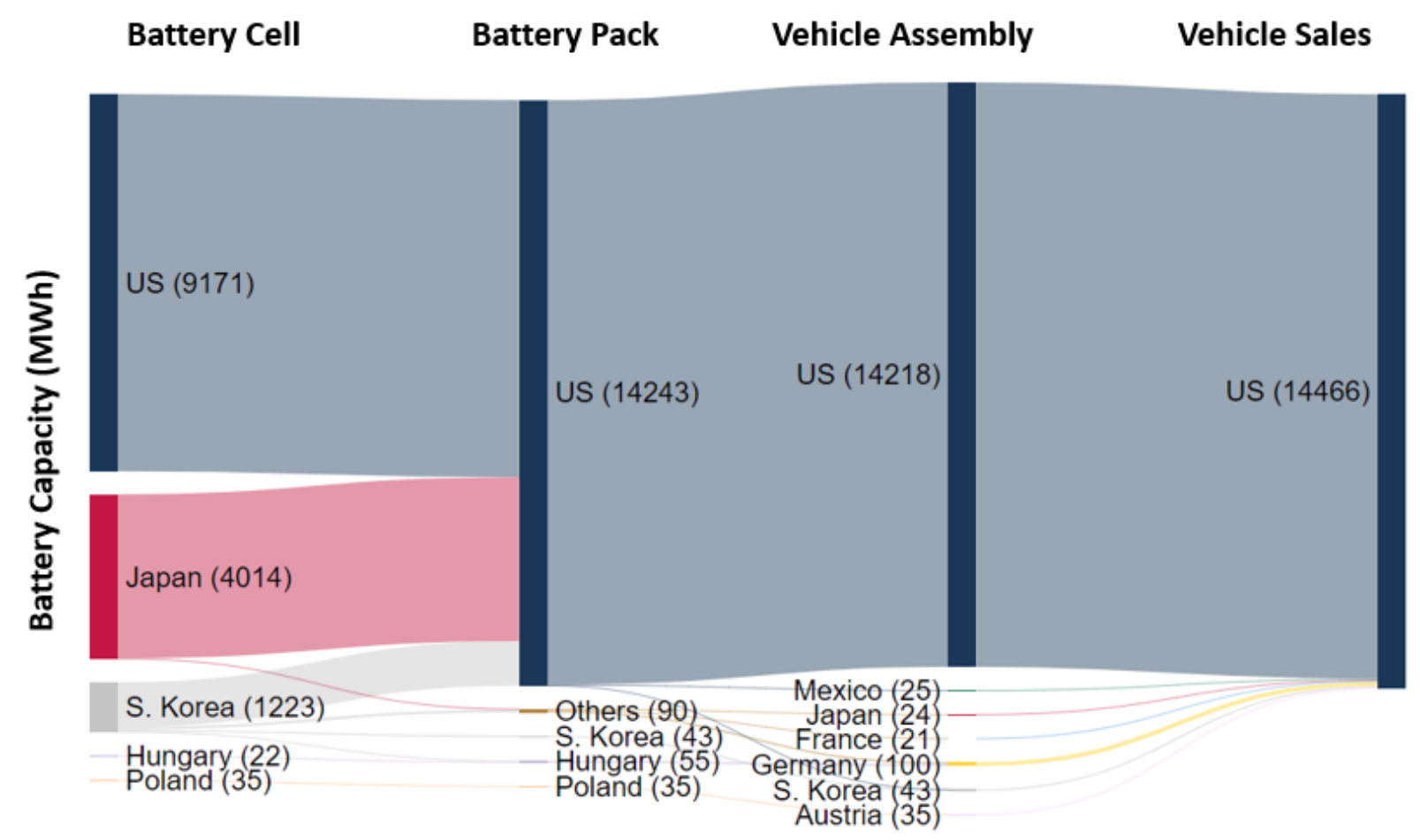

FIGURE A-48 2018 Total capacity (MWh) of Li-ion batteries supplied to the U.S. BEV market by production location. “Others” for battery pack includes Germany and Japan.

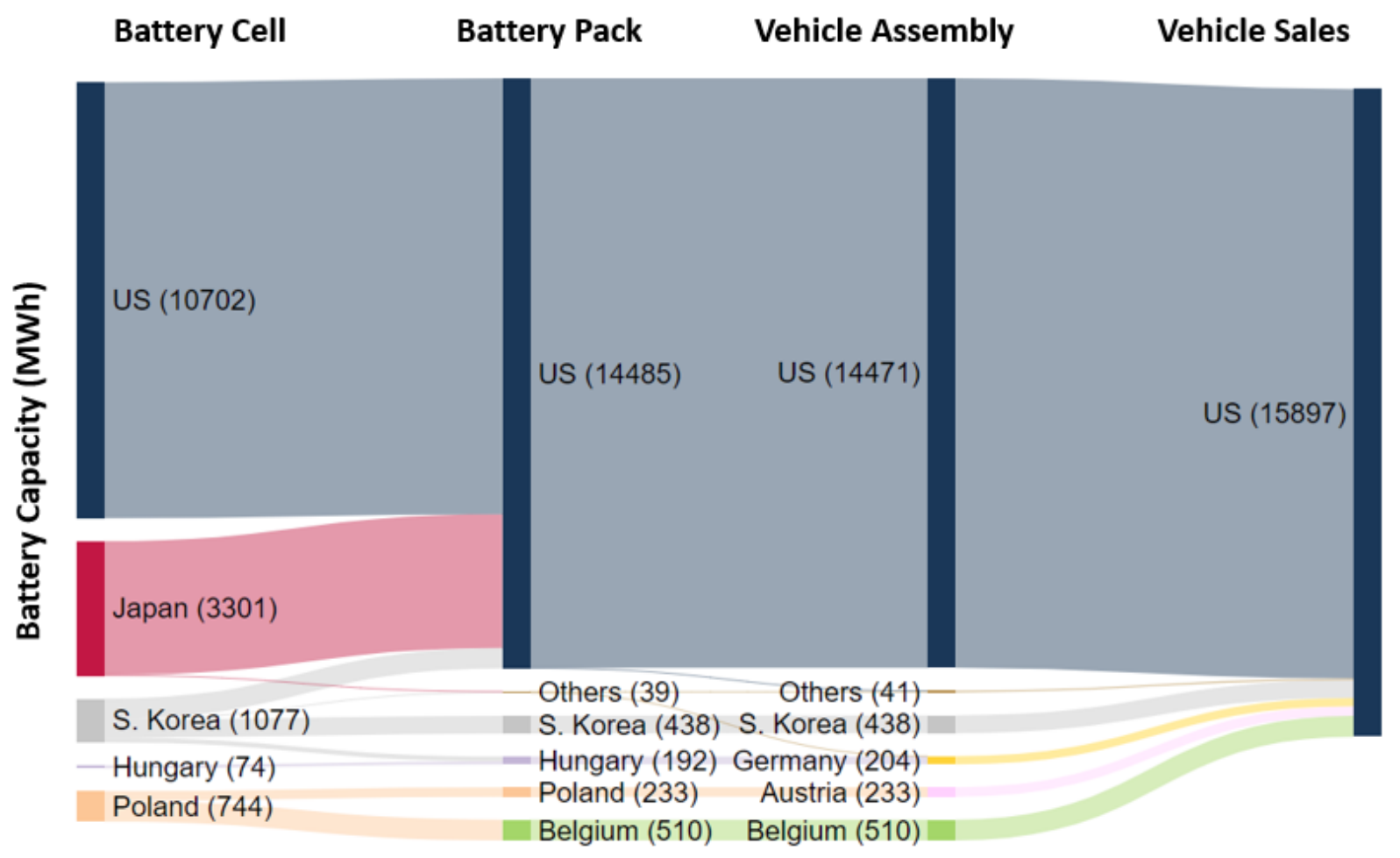

FIGURE A-49 2019 Total capacity (MWh) of Li-ion batteries supplied to the U.S. BEV market by production location. "Others" for battery pack includes Germany and Japan. "Others" for vehicle assembly includes France, Mexico, and Japan. 


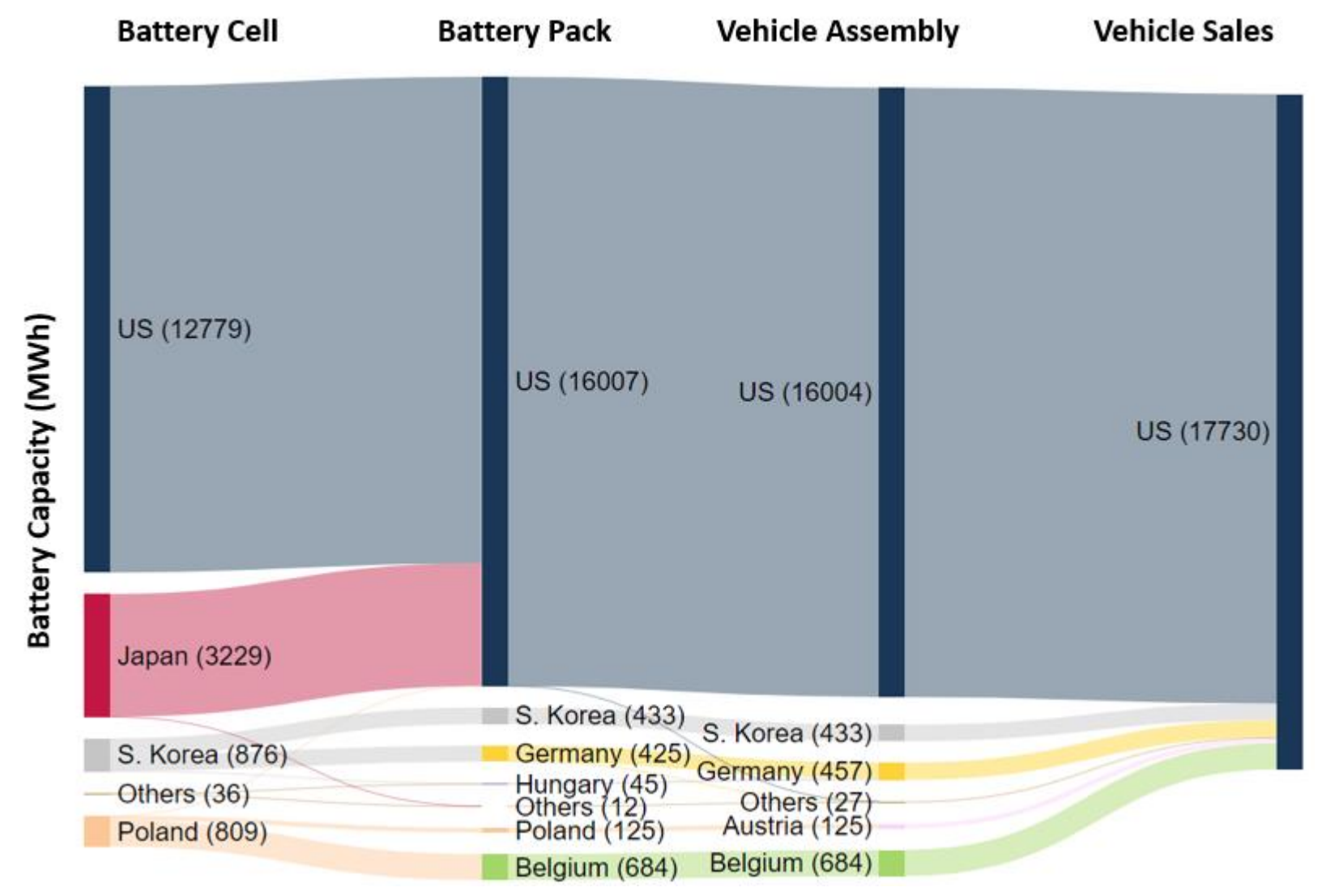

FIGURE A-50 2020 Total capacity (MWh) of Li-ion batteries supplied to the U.S. BEV market by production location. "Others" for battery cell includes Hungary and China. "Others" for battery pack includes Japan and China. "Others" for vehicle assembly includes Mexico, Japan, China, and United Kingdom.

Figures A-51 through A-60 show the number of battery packs/vehicle units for battery cell, battery pack, vehicle assembly, vehicle sale, by location, only BEVs. Note that the following annual diagrams for battery packs/vehicle units by country are on the same scale: one unit corresponds to the same height in each figure. Also note that the values are measured in thousands of units. 


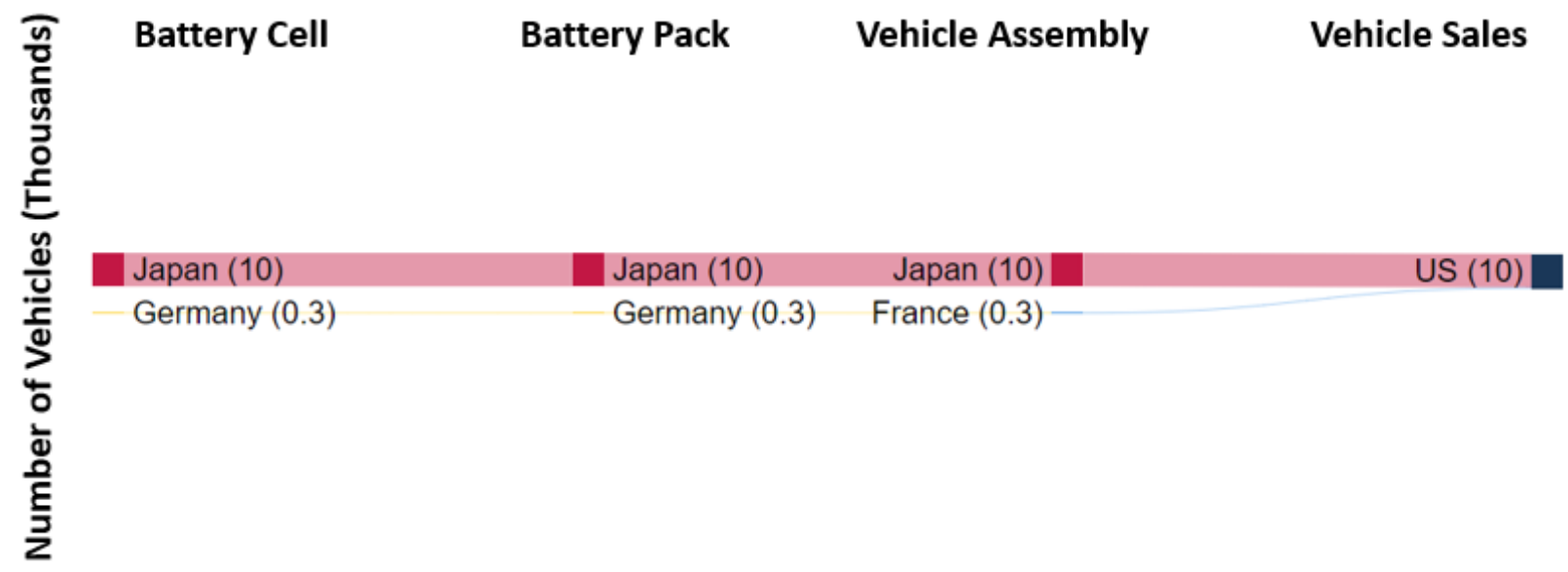

FIGURE A-51 2011 Number of battery packs (or vehicles) supplied to the U.S. BEV market by production location.

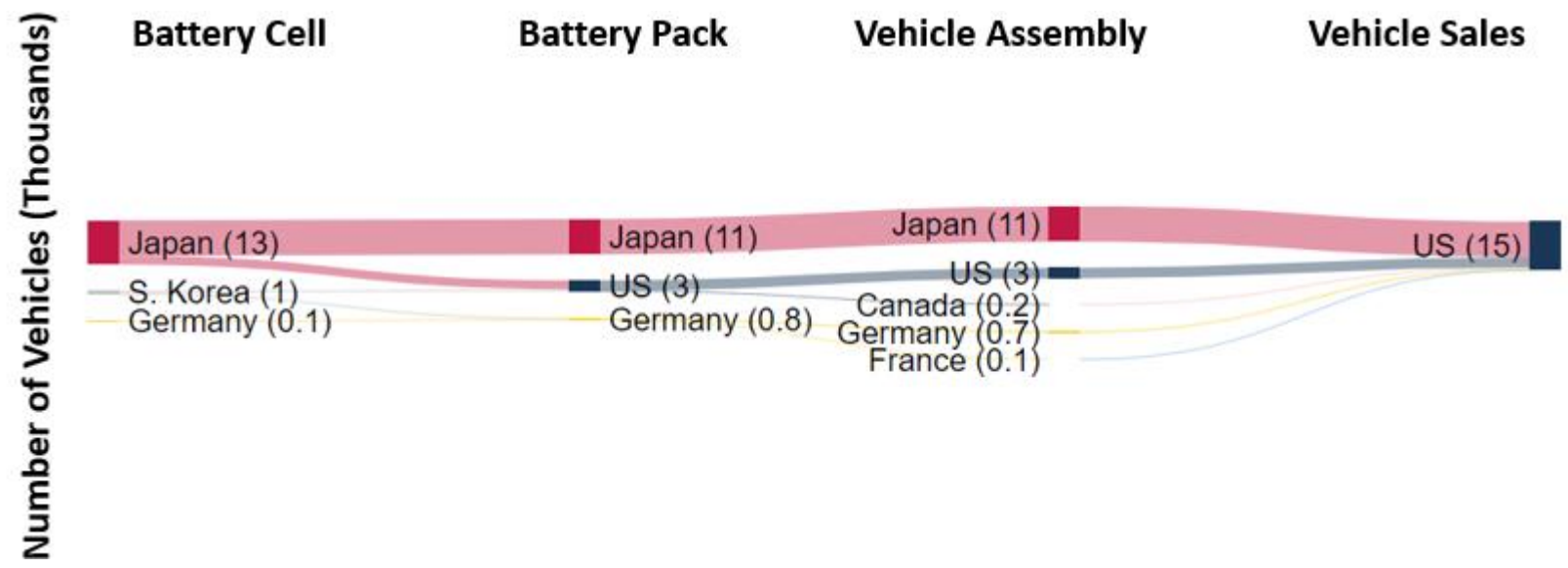

FIGURE A-52 2012 Number of battery packs (or vehicles) supplied to the U.S. BEV market by production location.

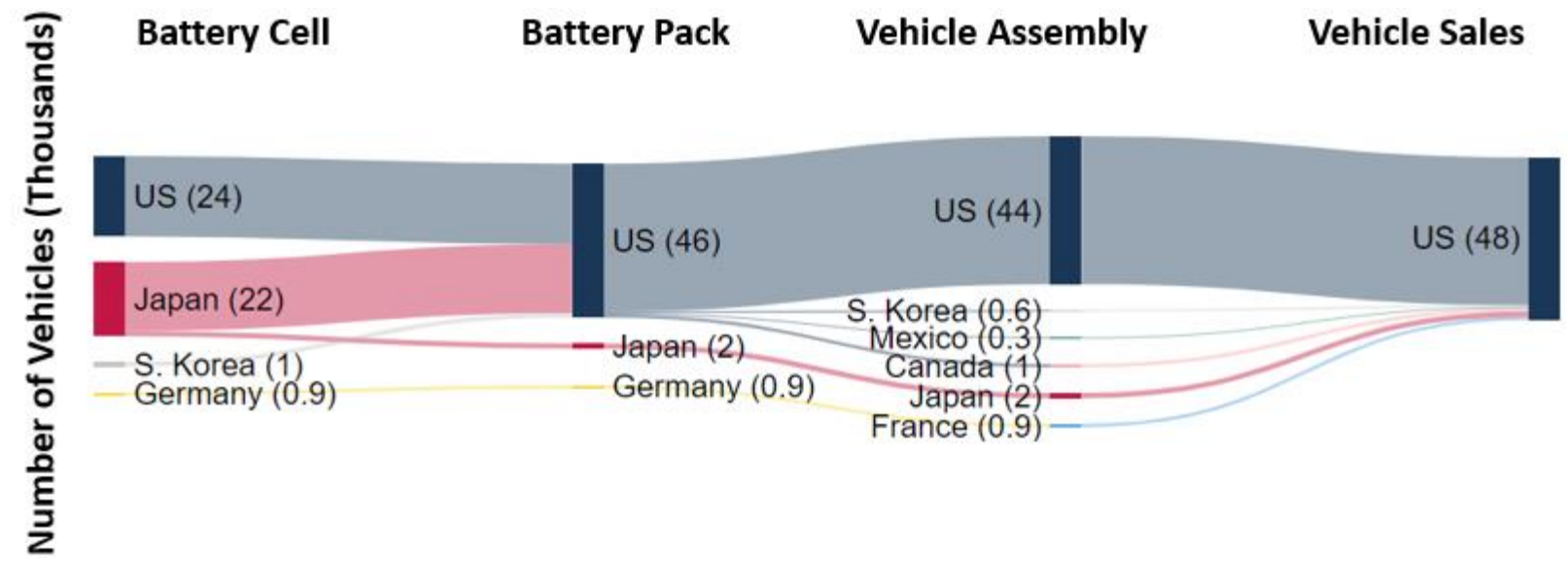

FIGURE A-53 2013 Number of battery packs (or vehicles) supplied to the U.S. BEV market by production location. 


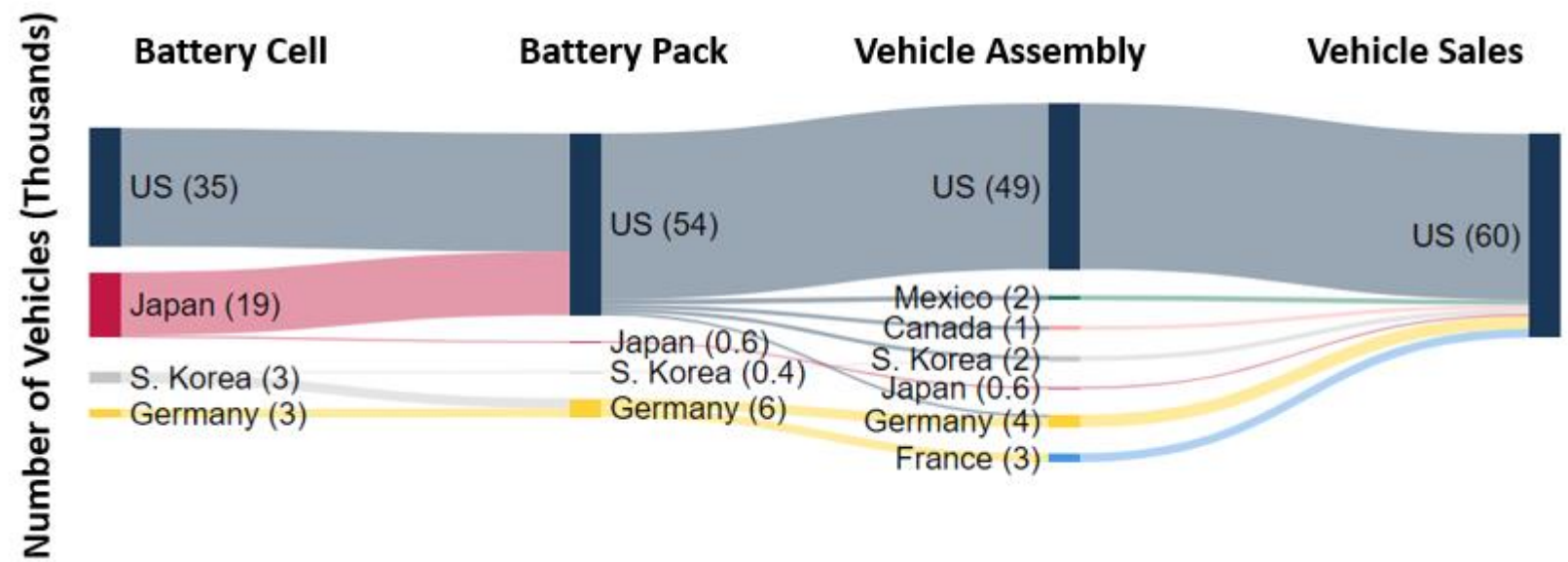

FIGURE A-54 2014 Number of battery packs (or vehicles) supplied to the U.S. BEV market by production location.

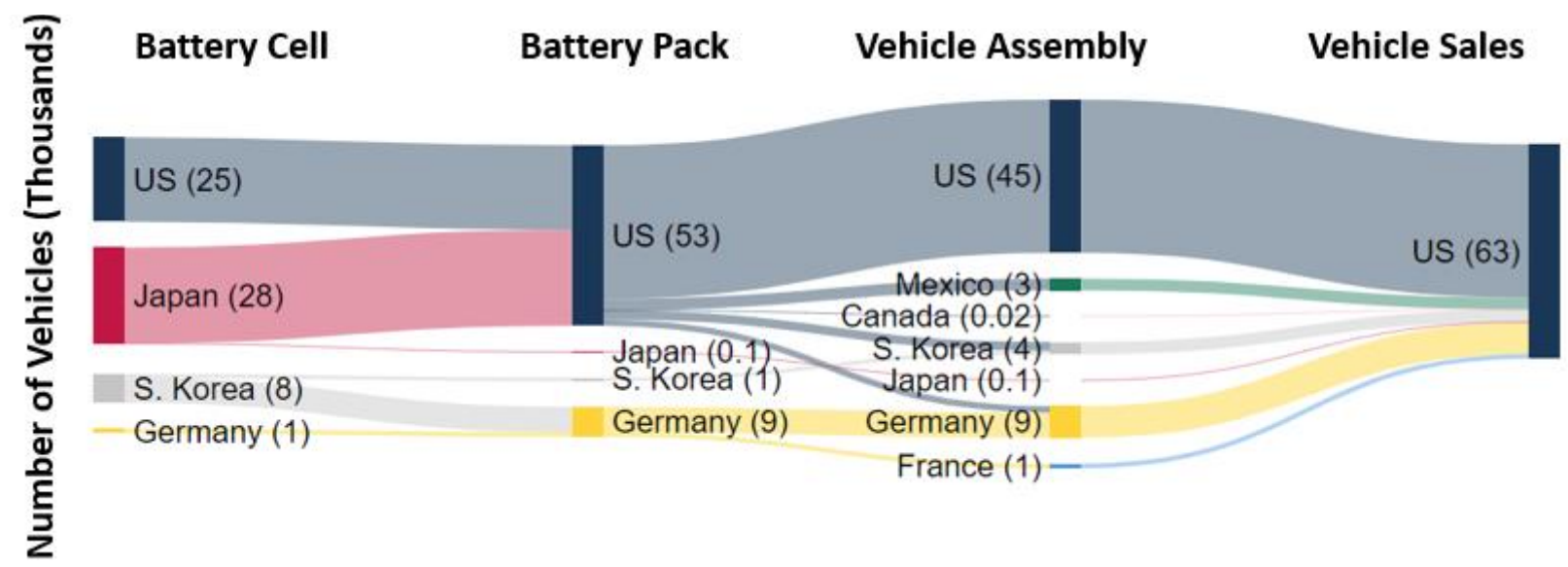

FIGURE A-55 2015 Number of battery packs (or vehicles) supplied to the U.S. BEV market by production location.

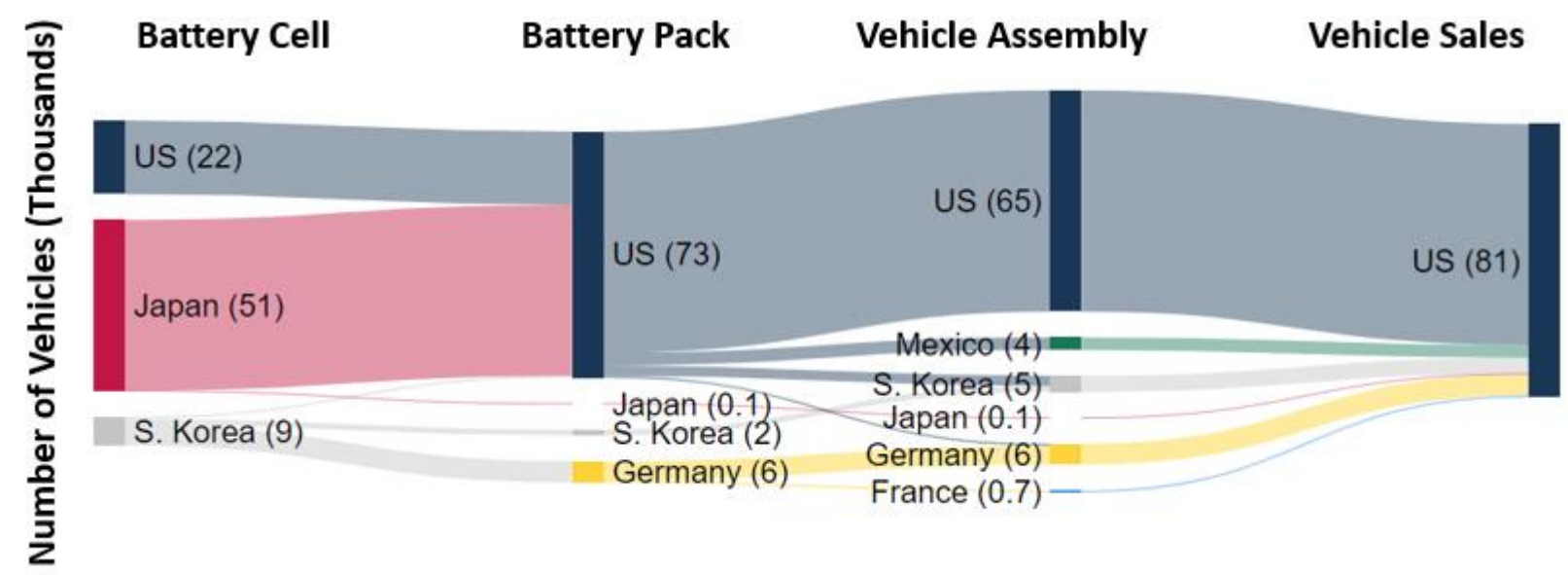

FIGURE A-56 2016 Number of battery packs (or vehicles) supplied to the U.S. BEV market by production location. 


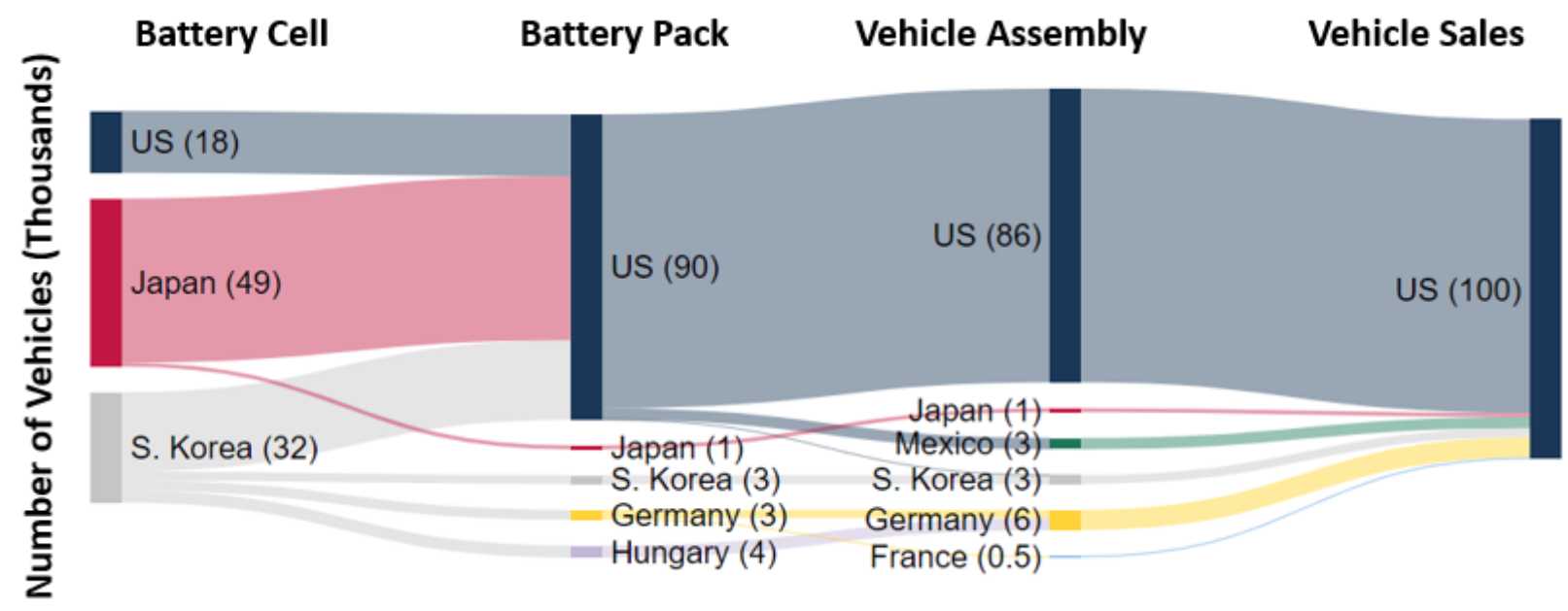

FIGURE A-57 2017 Number of battery packs (or vehicles) supplied to the U.S. BEV market by production location.

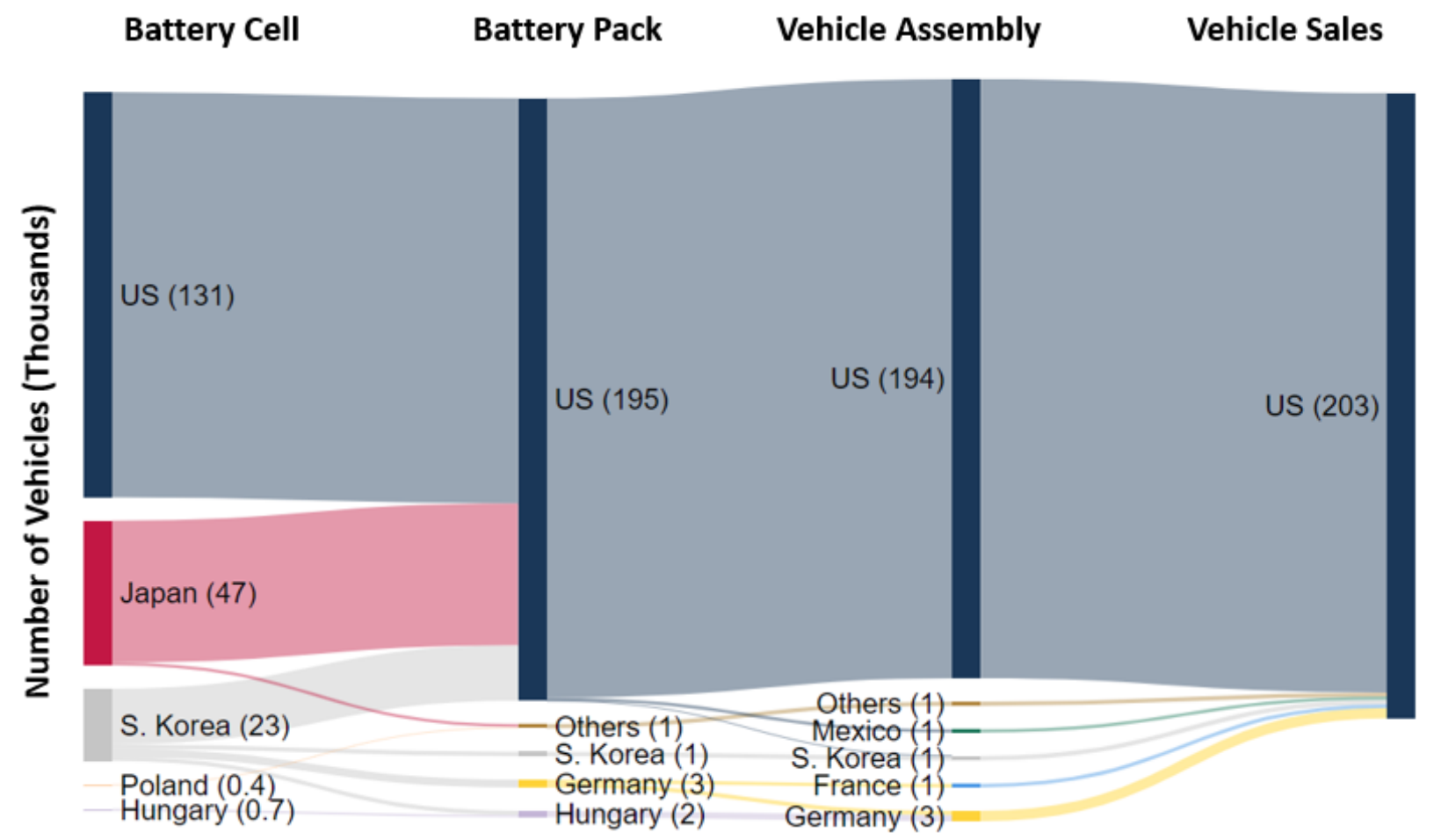

FIGURE A-58 2018 Number of battery packs (or vehicles) supplied to the U.S. BEV market by production location. "Others" for battery pack includes Poland and Japan. "Others" for vehicle assembly includes Japan and Austria. 


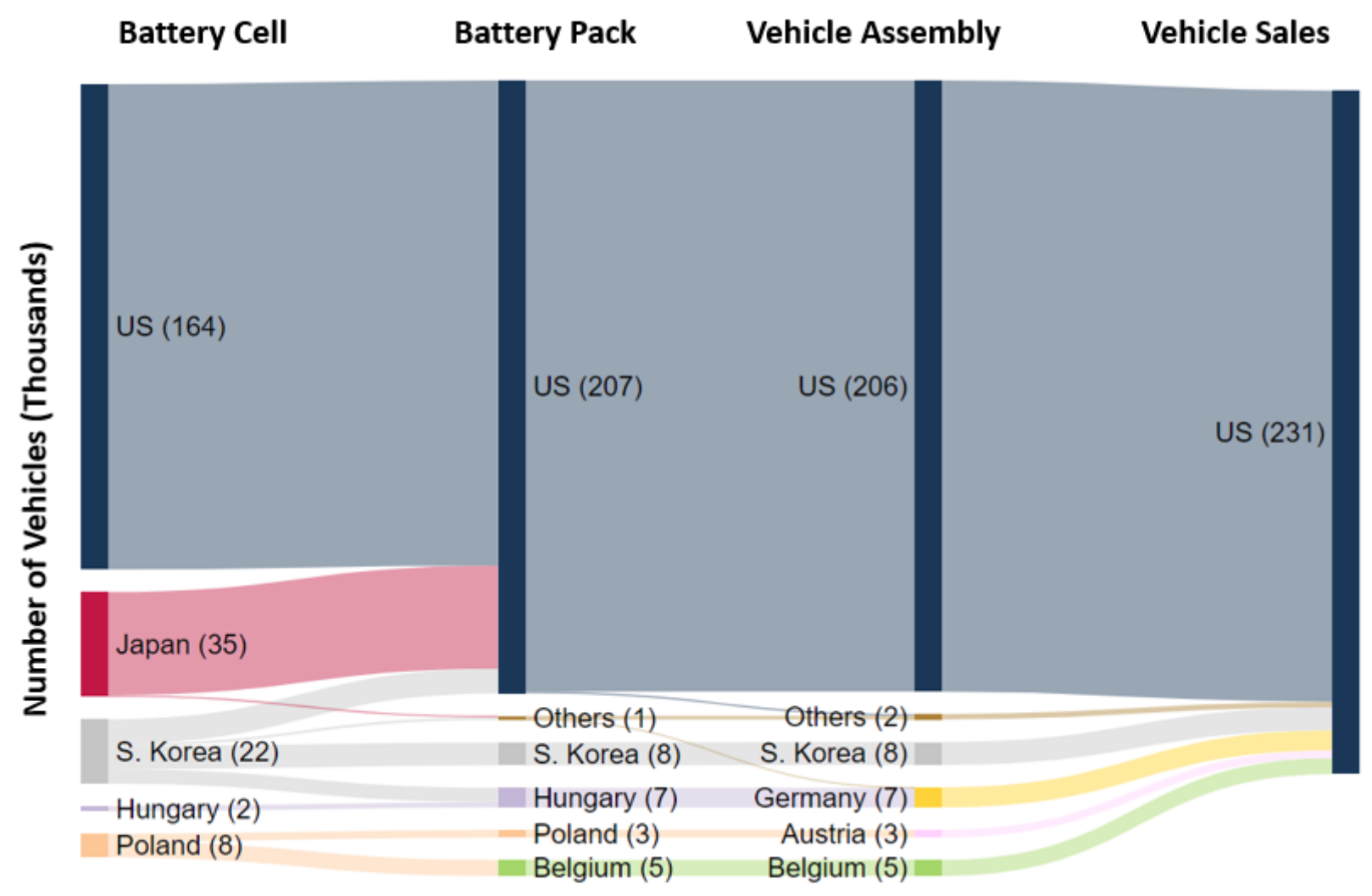

FIGURE A-59 2019 Number of battery packs (or vehicles) supplied to the U.S. BEV market by production location. "Others" for battery pack includes Germany and Japan. "Others" for vehicle assembly includes France, Mexico, and Japan. 


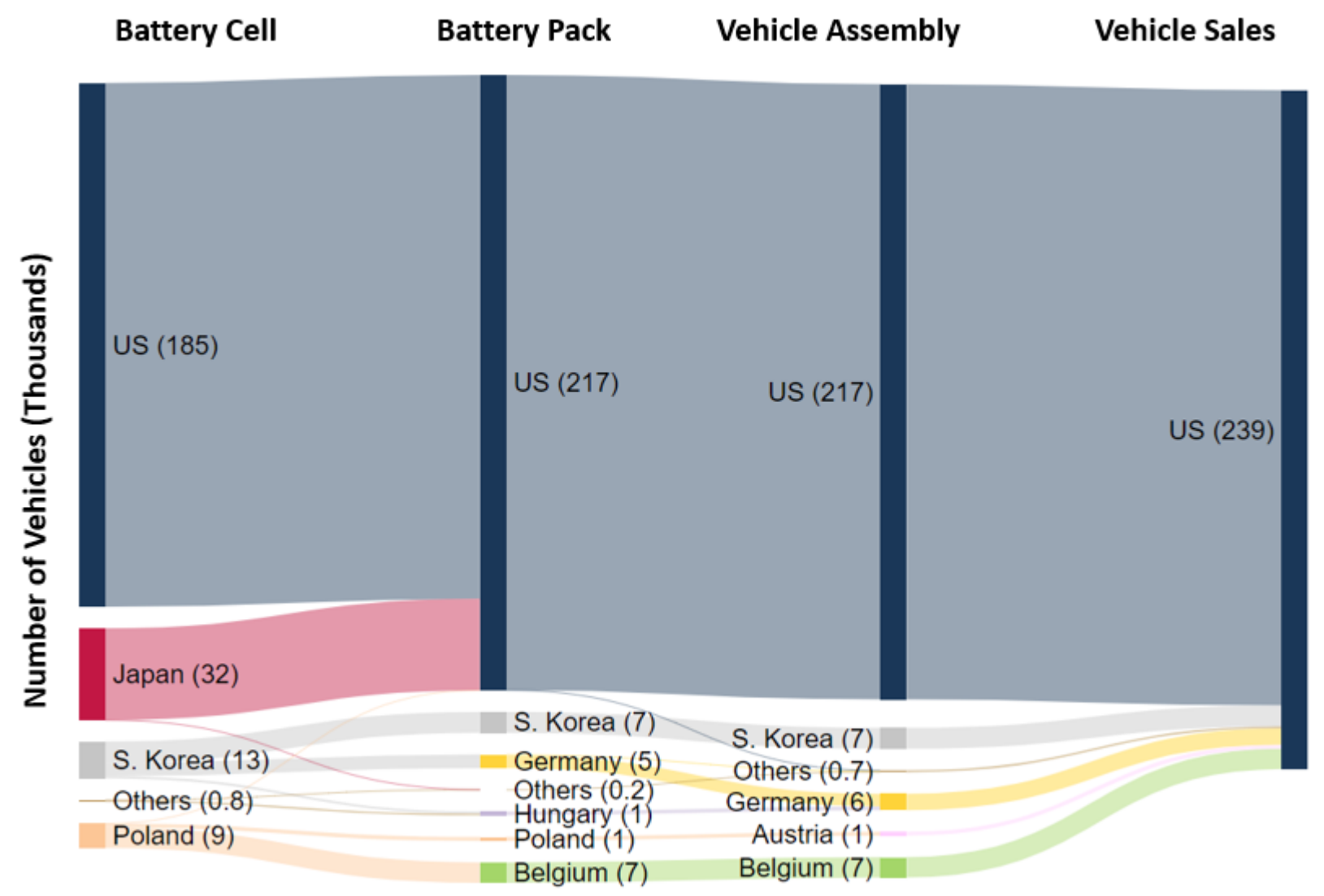

FIGURE A-60 2020 Number of battery packs (or vehicles) supplied to the U.S. BEV market by production location. "Others" for battery cell includes Hungary and China. "Others" for battery pack includes Japan and China. "Others" for vehicle assembly includes Mexico, Japan, China, and United Kingdom.

Figures A-61 through A-70 show battery capacity for battery cell, battery pack, vehicle assembly, vehicle sale, by location, only PHEVs. Note that the following annual diagrams for battery capacity by country are on the same scale: one unit corresponds to the same height in each figure. Also note that the values are measured in MWh. 


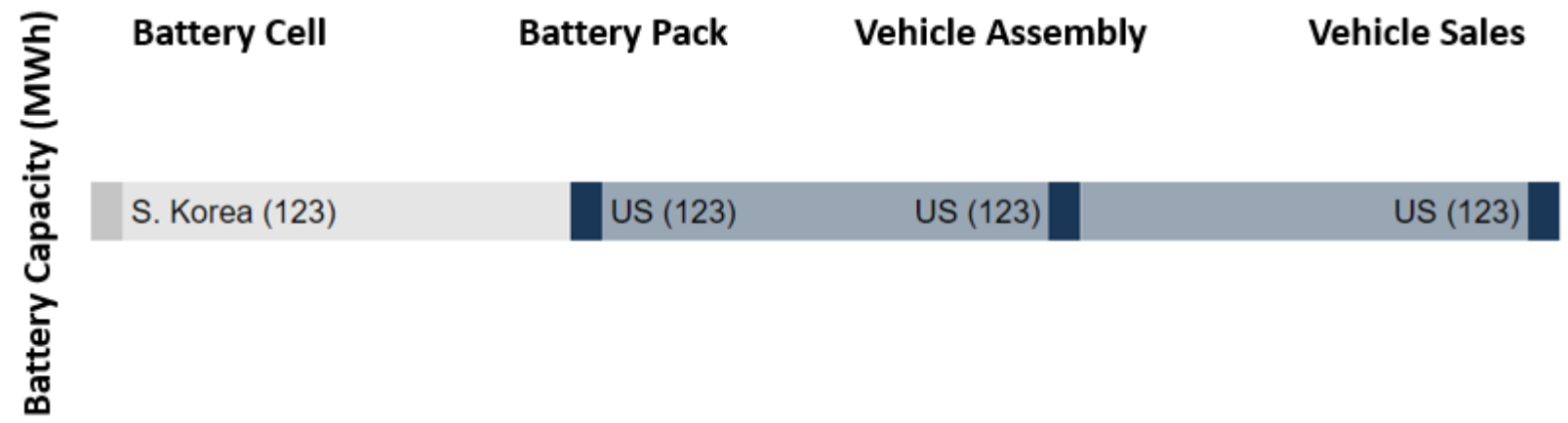

FIGURE A-61 2011 Total capacity (MWh) of Li-ion batteries supplied to the U.S. PHEV market by production location.

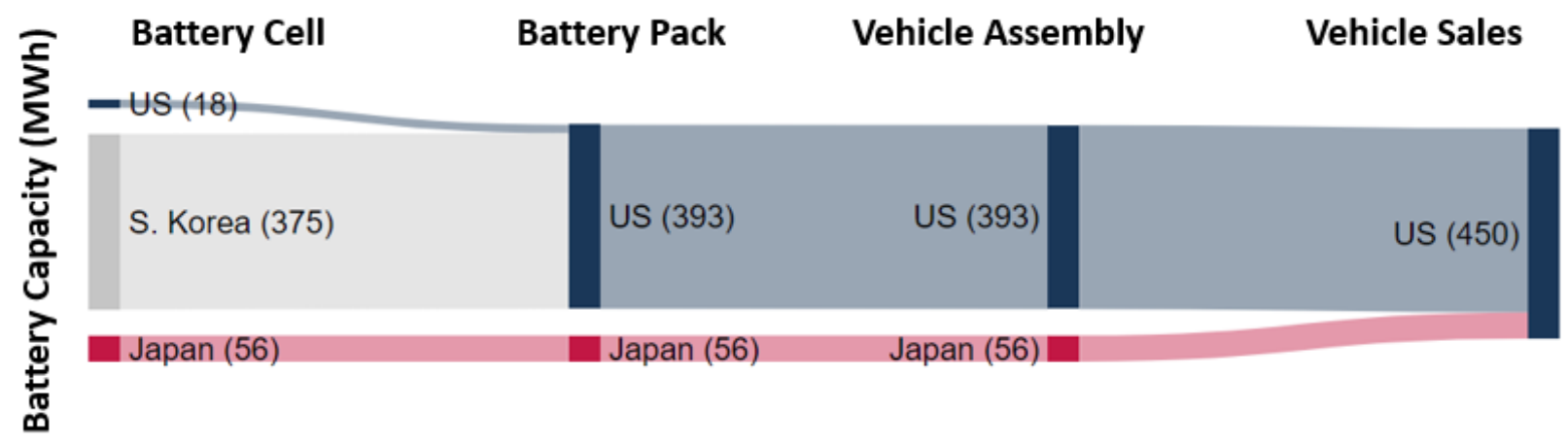

FIGURE A-62 2012 Total capacity (MWh) of Li-ion batteries supplied to the U.S. PHEV market by production location.

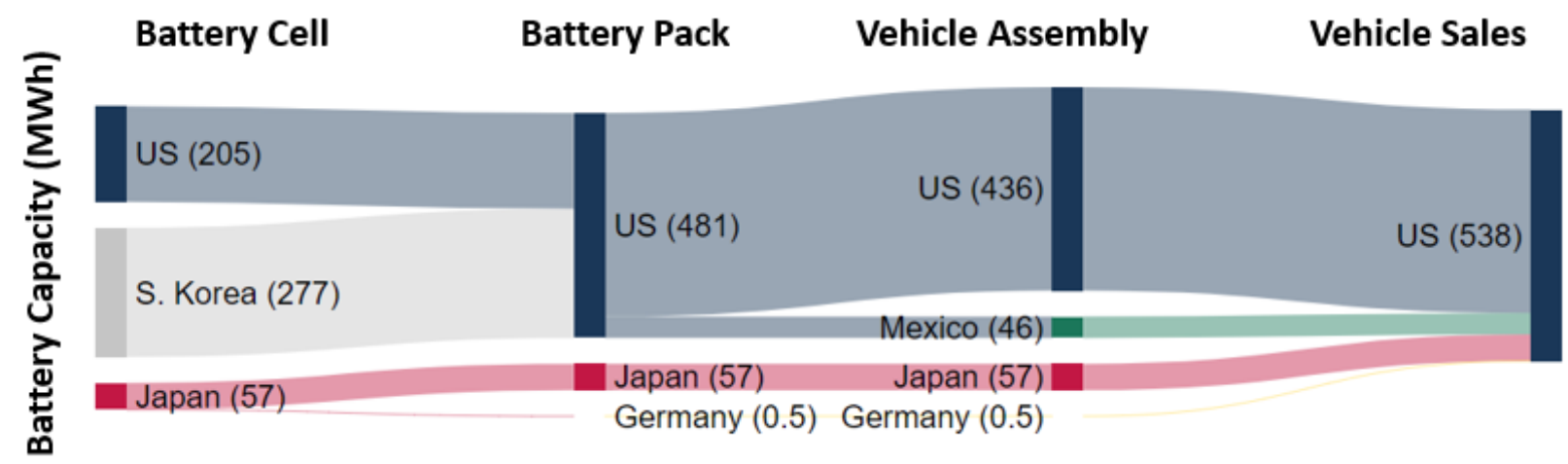

FIGURE A-63 2013 Total capacity (MWh) of Li-ion batteries supplied to the U.S. PHEV market by production location. 


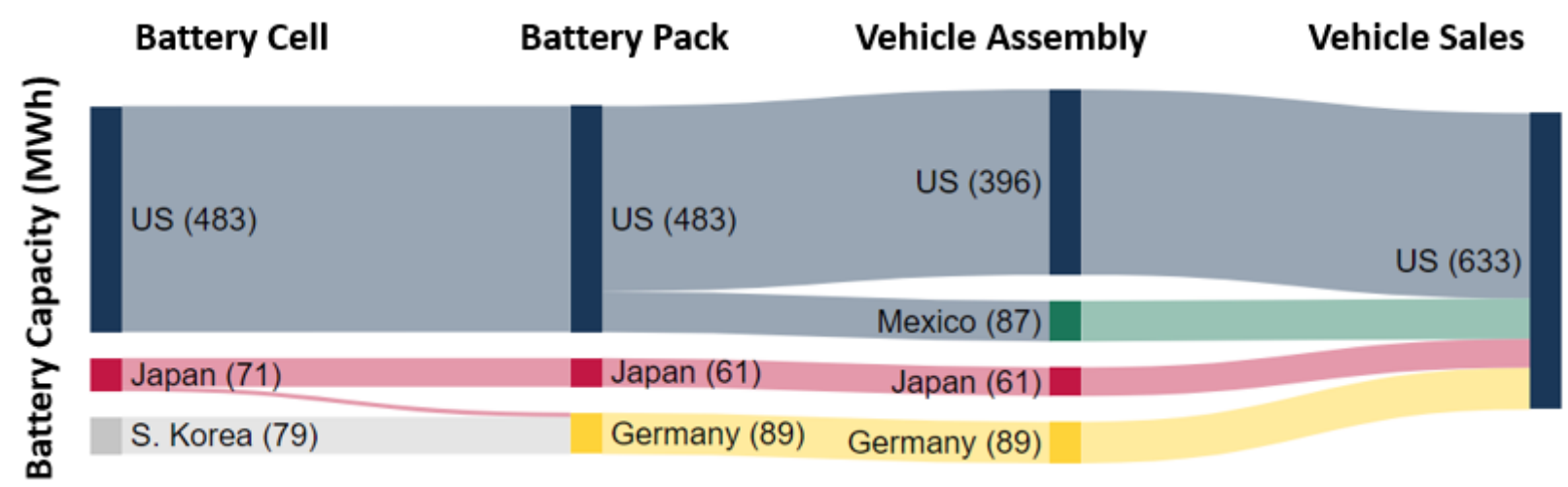

FIGURE A-64 2014 Total capacity (MWh) of Li-ion batteries supplied to the U.S. PHEV market by production location.

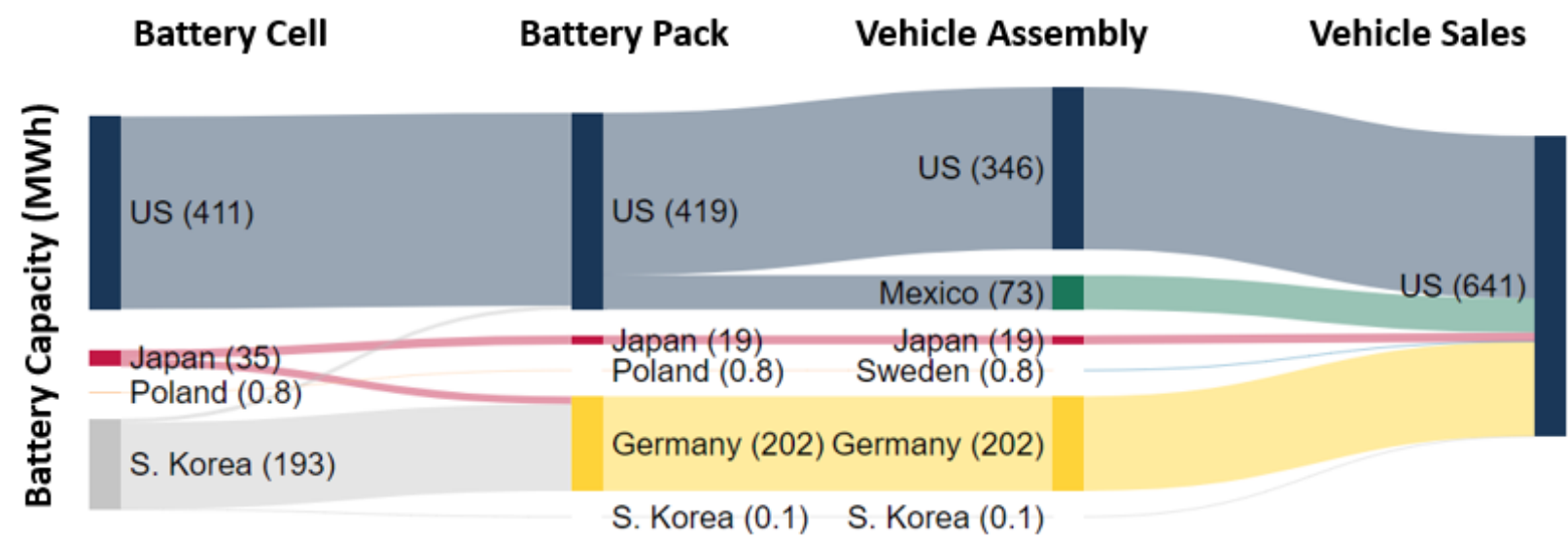

FIGURE A-65 2015 Total capacity (MWh) of Li-ion batteries supplied to the U.S. PHEV market by production location.

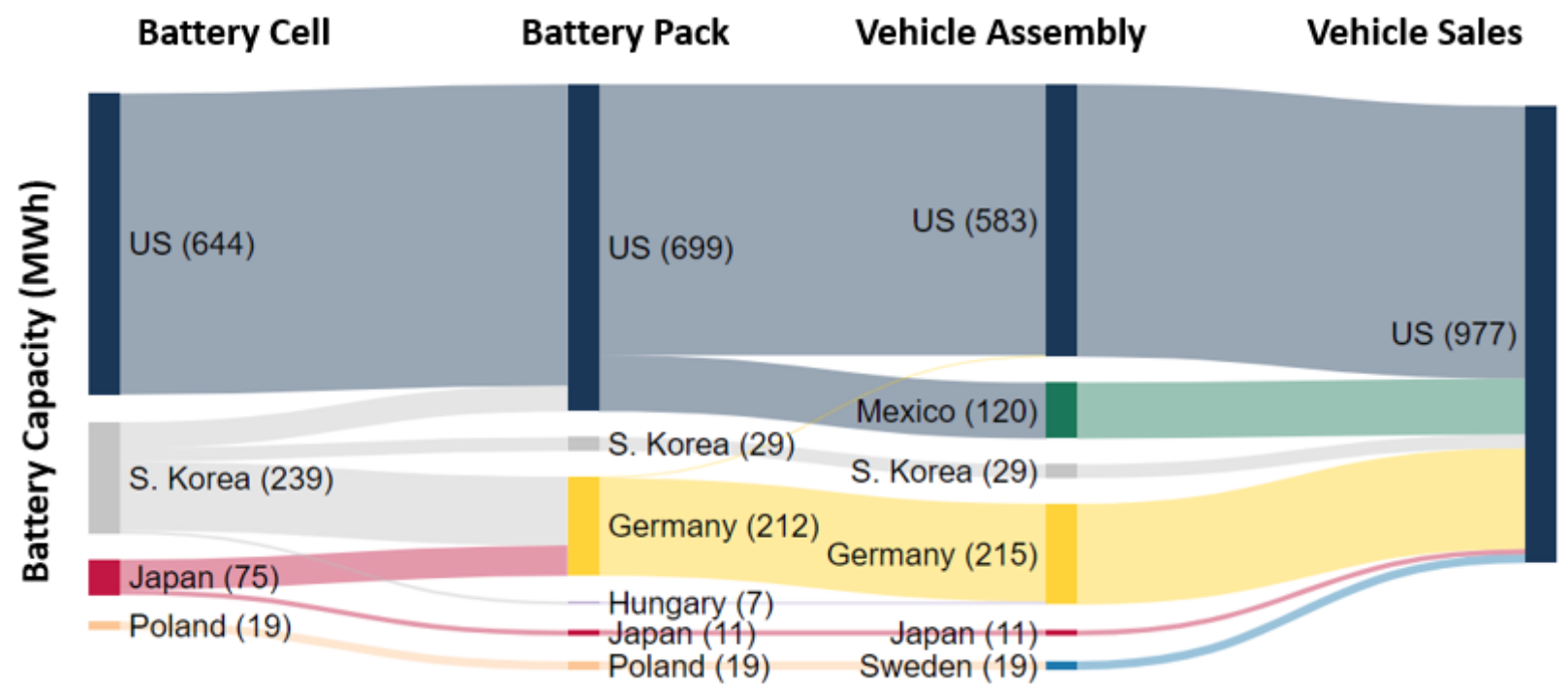

FIGURE A-66 2016 Total capacity (MWh) of Li-ion batteries supplied to the U.S. PHEV market by production location. 


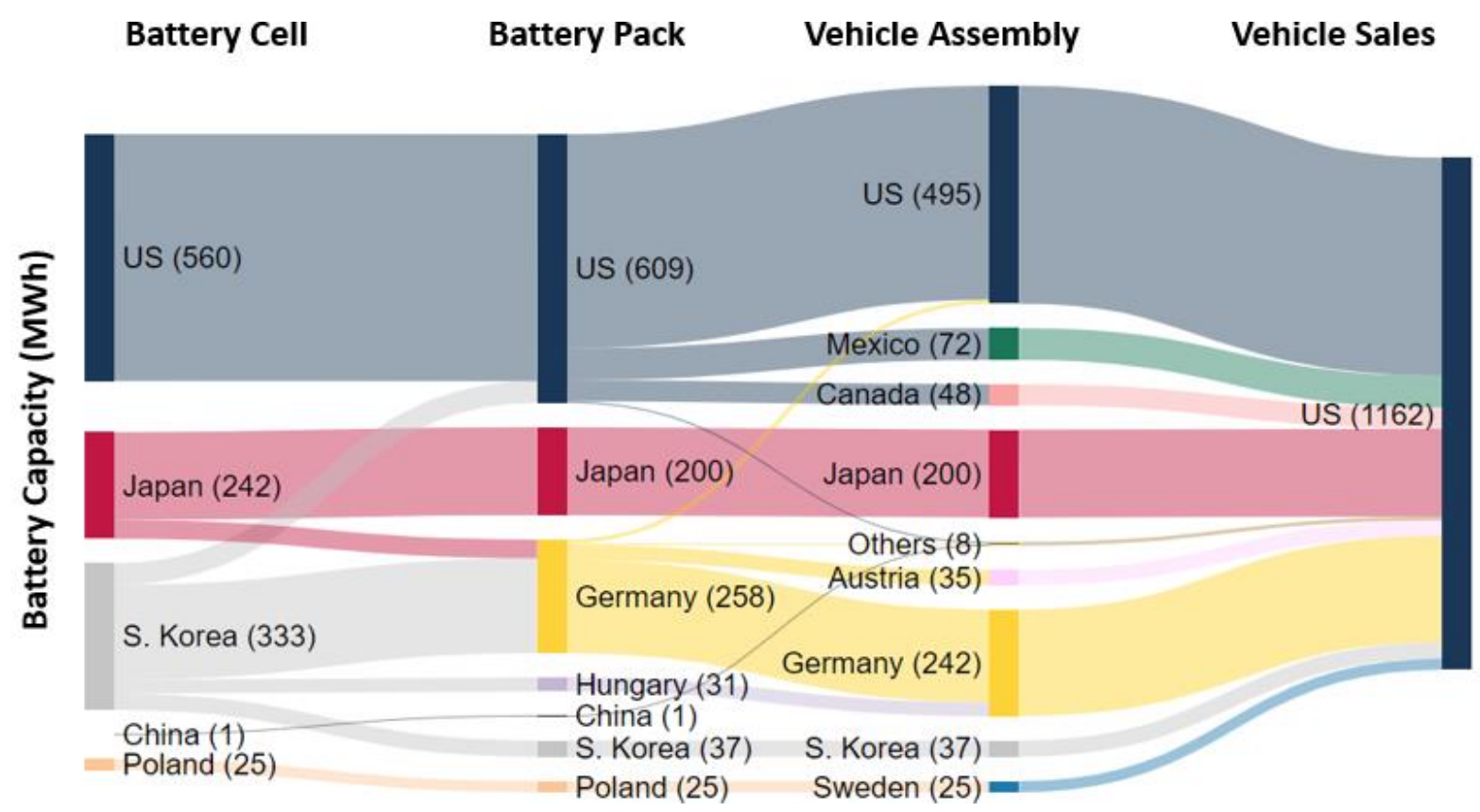

FIGURE A-67 2017 Total capacity (MWh) of Li-ion batteries supplied to the U.S. PHEV market by production location. "Others" for vehicle assembly includes China and Netherlands.

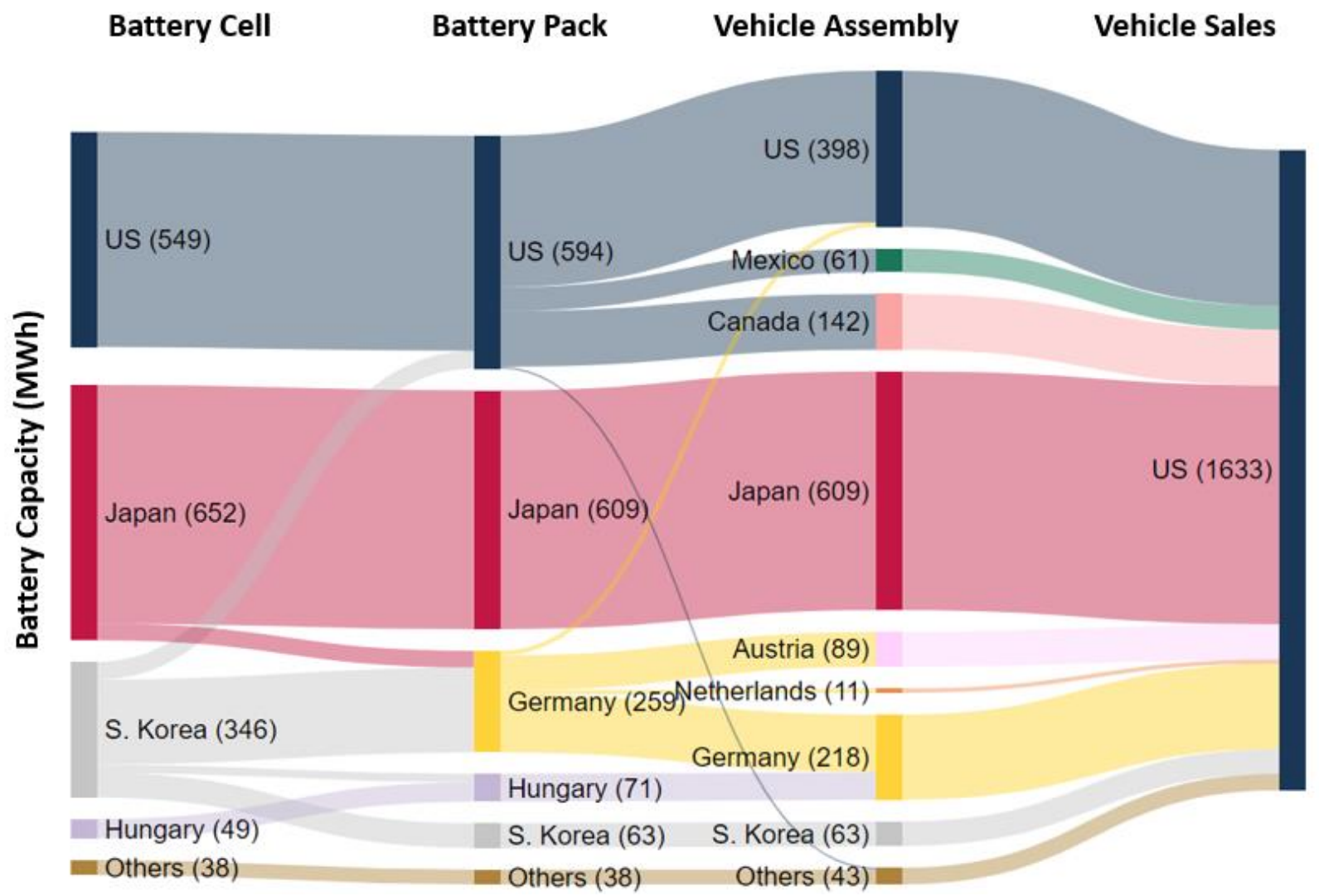

FIGURE A-68 2018 Total capacity (MWh) of Li-ion batteries supplied to the U.S. PHEV market by production location. "Others" for battery cell includes Poland and China. "Others" for battery pack includes Poland and China. "Others" for vehicle assembly includes Sweden and China. 


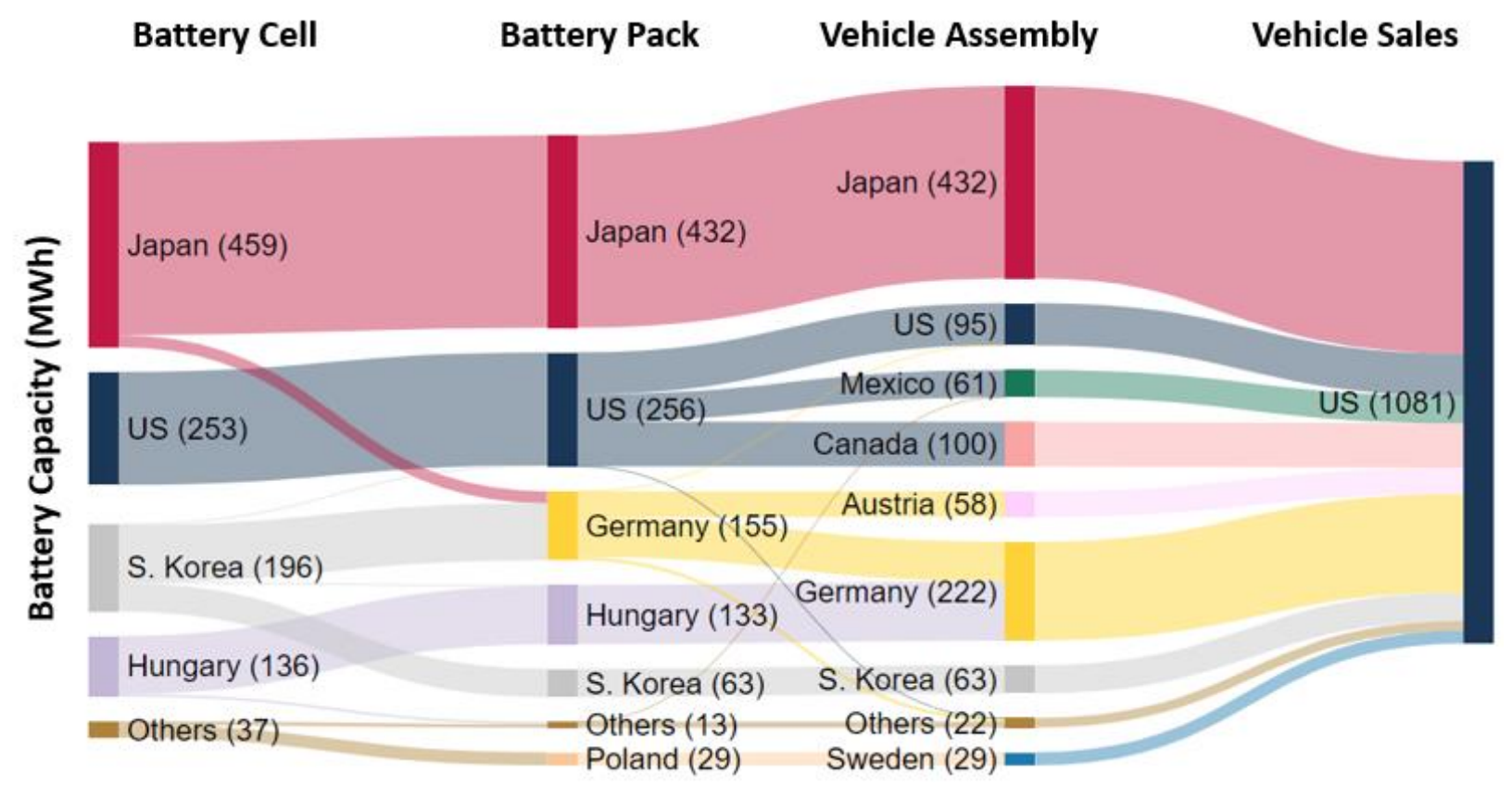

FIGURE A-69 2019 Total capacity (MWh) of Li-ion batteries supplied to the U.S. PHEV market by production location. "Others" for battery cell includes Poland and China. "Others" for battery pack includes China, Belgium, and United Kingdom. "Others" for vehicle assembly includes Netherlands, China, Belgium, and United Kingdom.

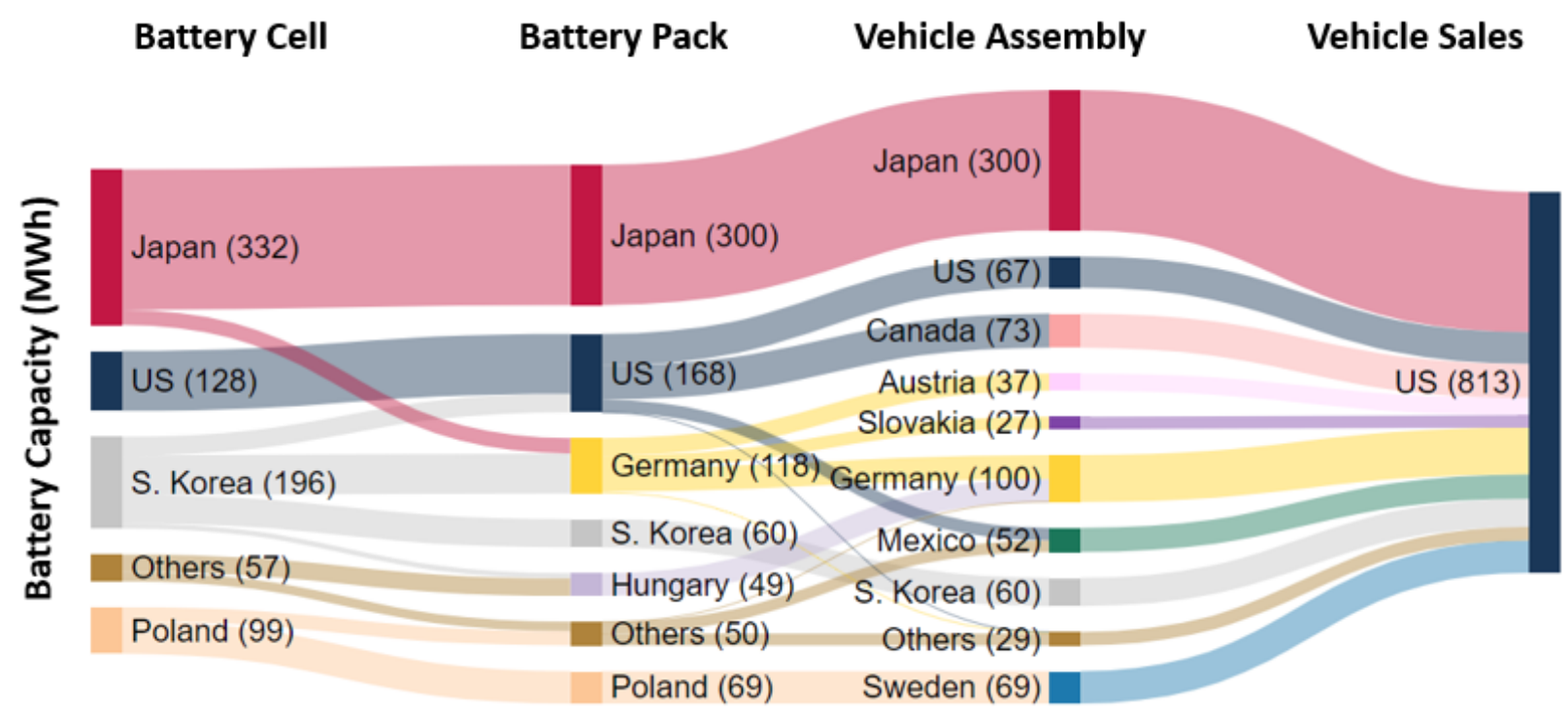

FIGURE A-70 2020 Total capacity (MWh) of Li-ion batteries supplied to the U.S. PHEV market by production location. "Others" for battery cell includes Hungary and China. "Others" for battery pack includes Belgium, United Kingdom, and China. "Others" for vehicle assembly includes Netherlands, Belgium, United Kingdom, and China. 
Figures A-71 through A-80 show the number of battery packs/vehicle units for battery cell, battery pack, vehicle assembly, vehicle sale, by location, only PHEVs. Note that the following annual diagrams for battery packs/vehicle units by country are on the same scale: one unit corresponds to the same height in each figure. Also note that the values are measured in thousands of units.

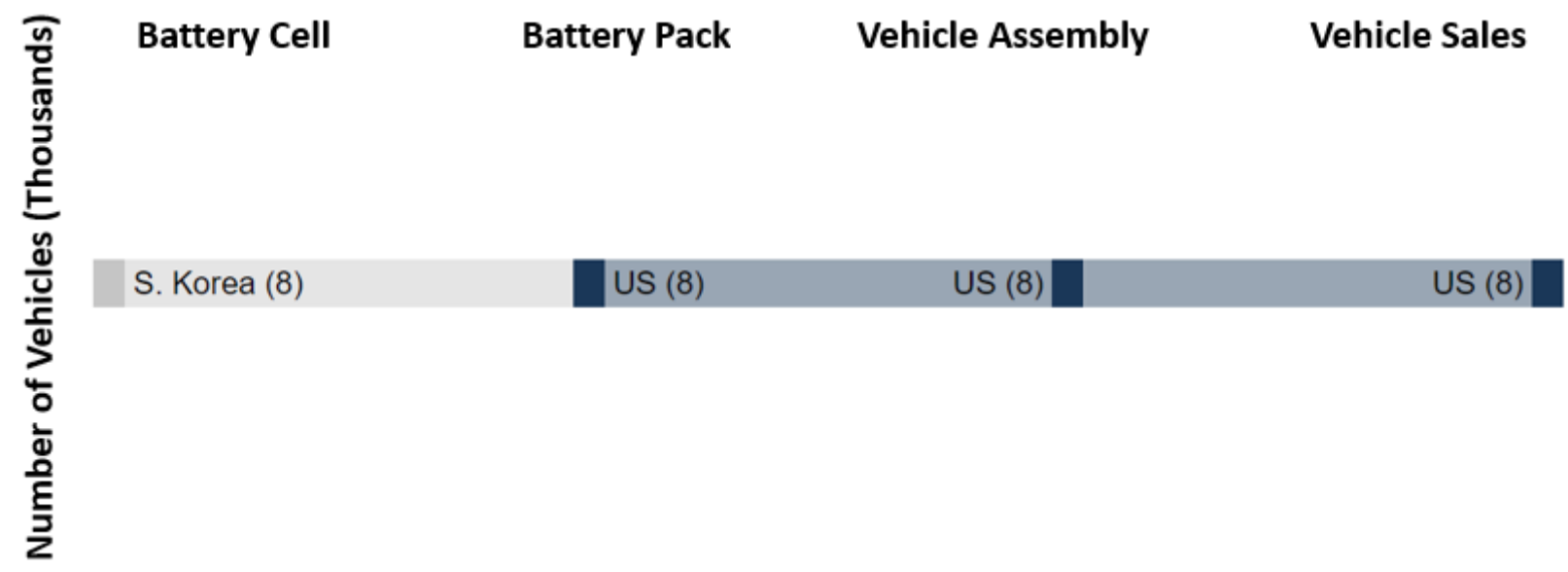

FIGURE A-71 2011 Number of battery packs (or vehicles) supplied to the U.S. PHEV market by production location.

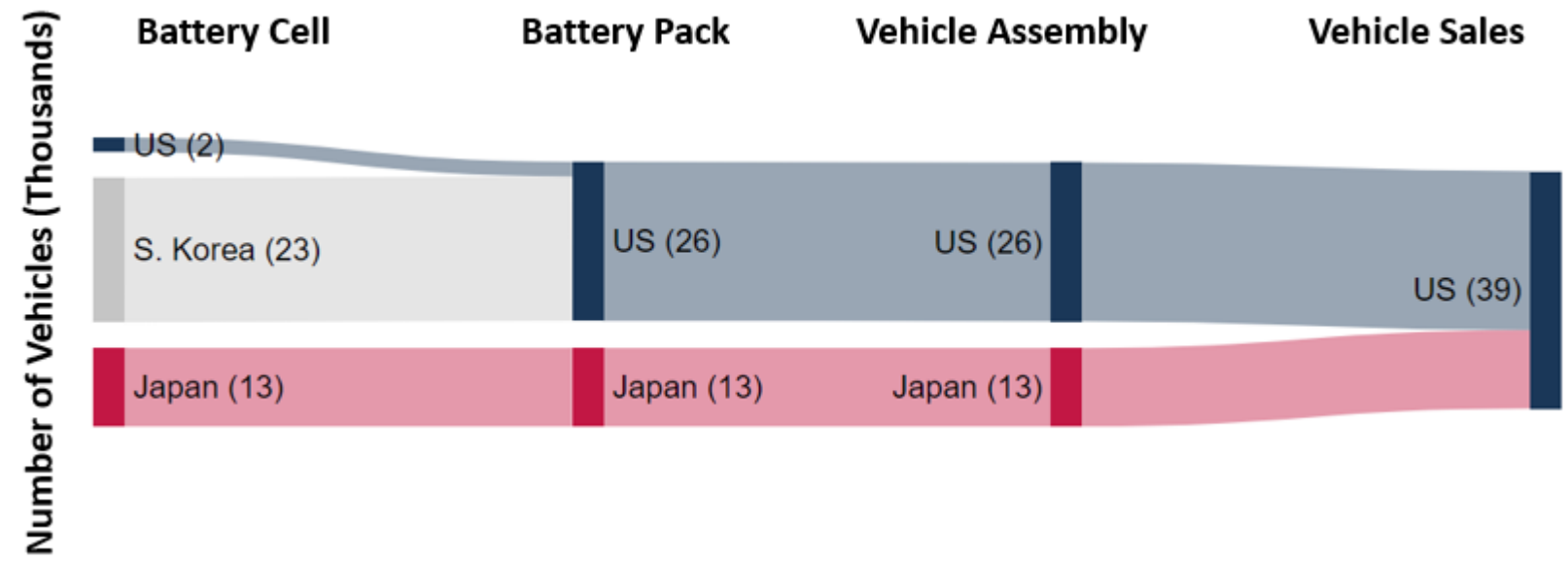

FIGURE A-72 2012 Number of battery packs (or vehicles) supplied to the U.S. PHEV market by production location. 


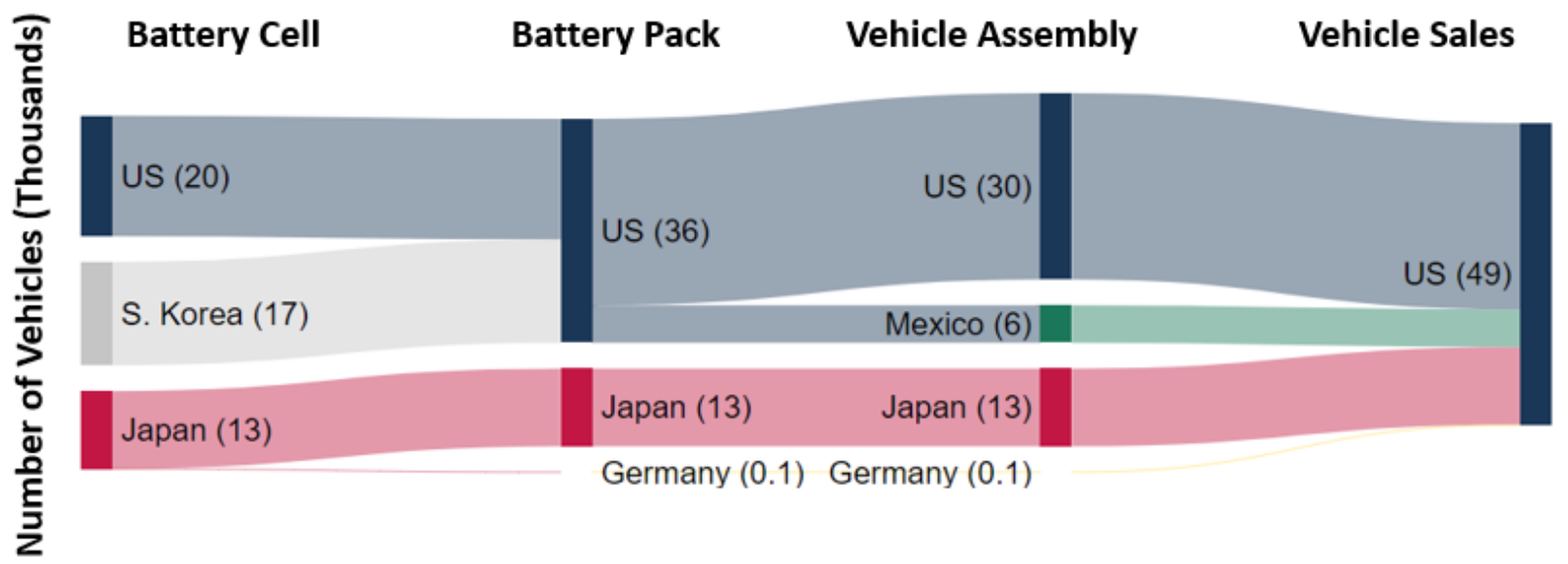

FIGURE A-73 2013 Number of battery packs (or vehicles) supplied to the U.S. PHEV market by production location.

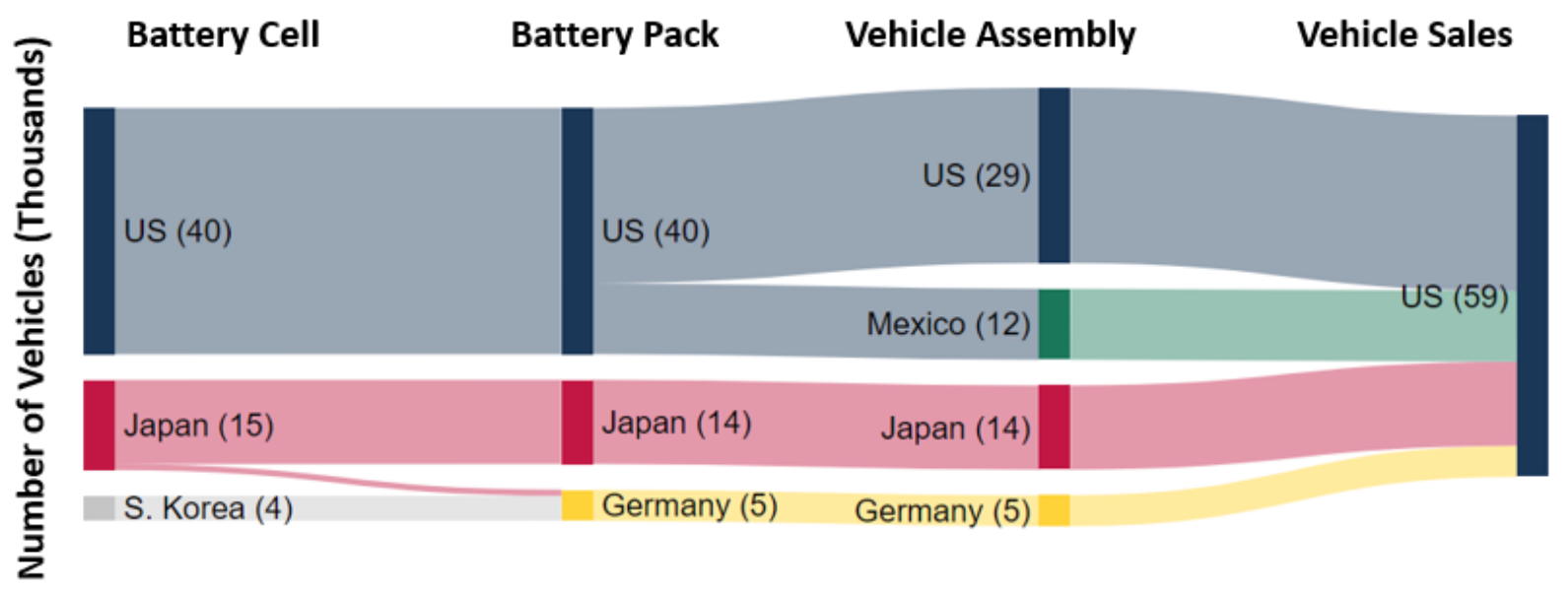

FIGURE A-74 2014 Number of battery packs (or vehicles) supplied to the U.S. PHEV market by production location.

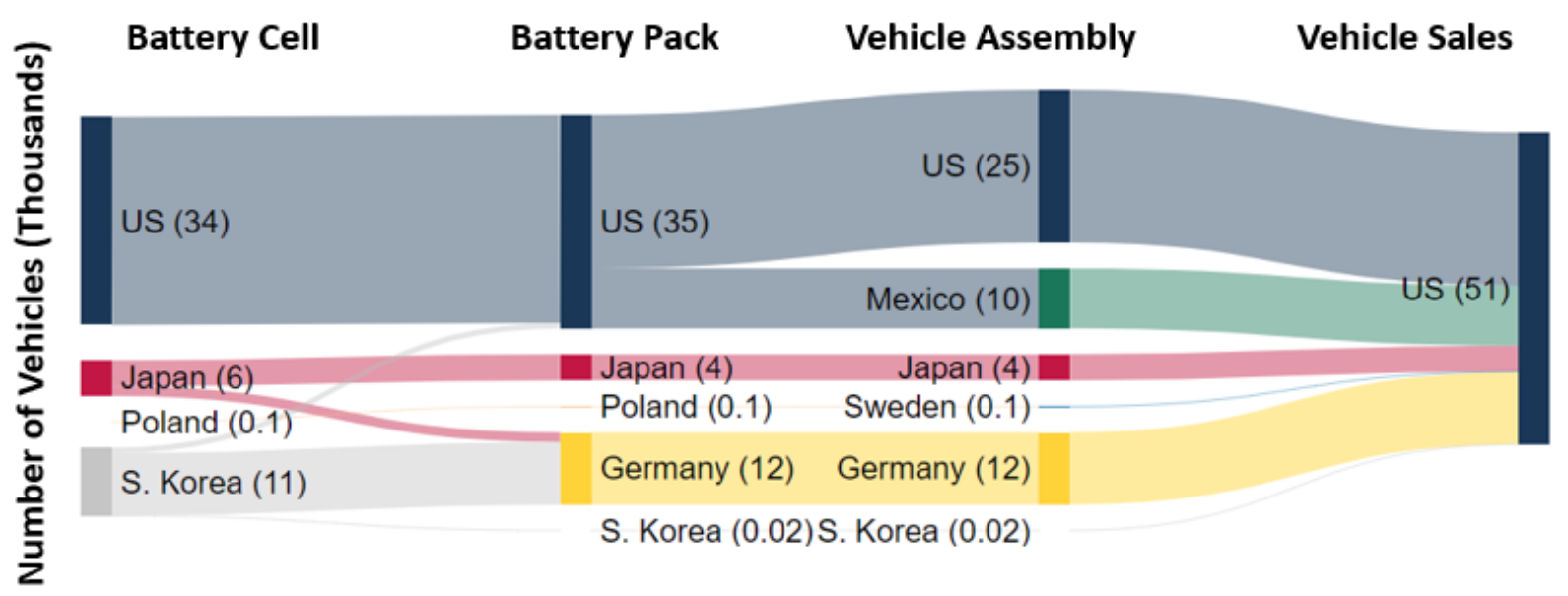

FIGURE A-75 2015 Number of battery packs (or vehicles) supplied to the U.S. PHEV market by production location. 


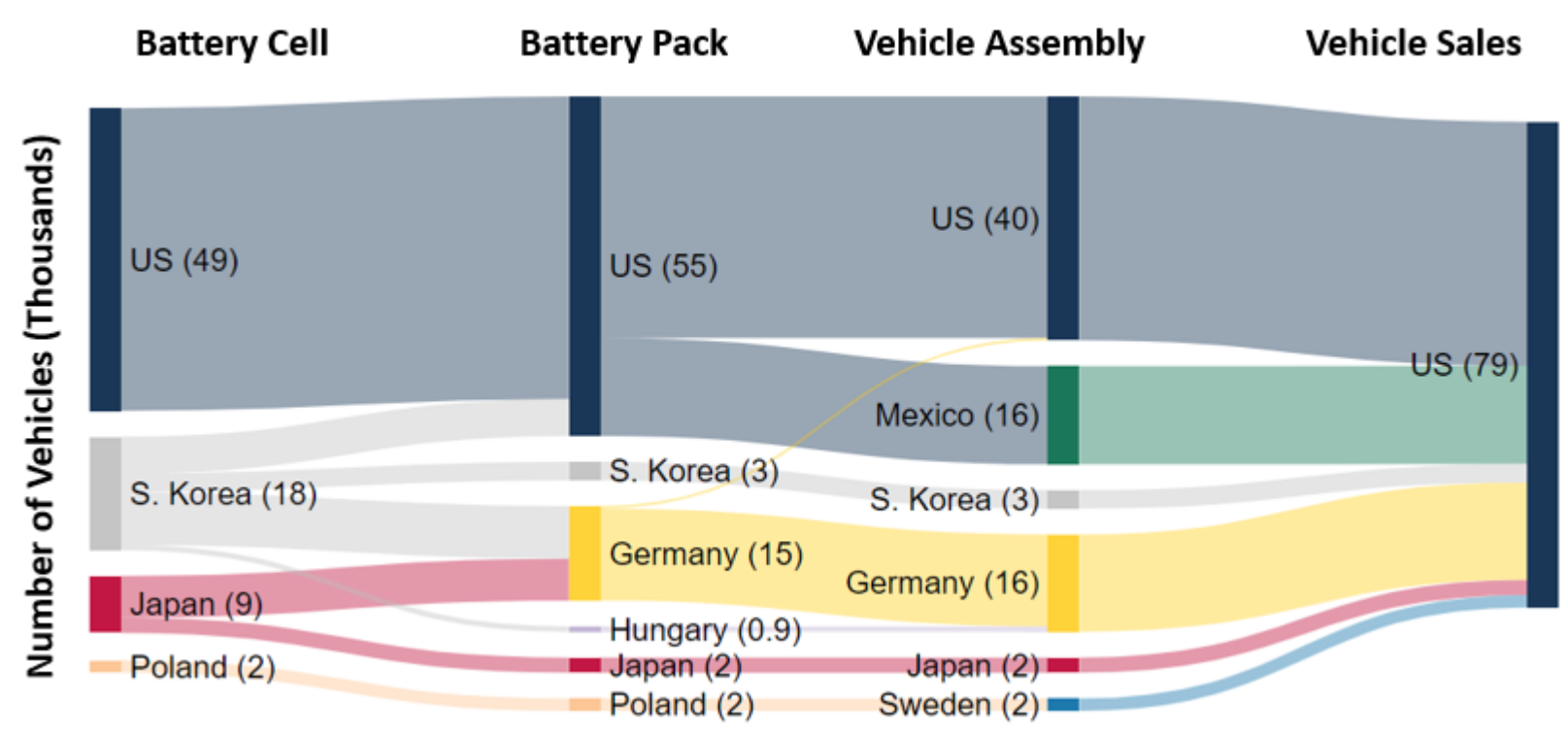

FIGURE A-76 2016 Number of battery packs (or vehicles) supplied to the U.S. PHEV market by production location.

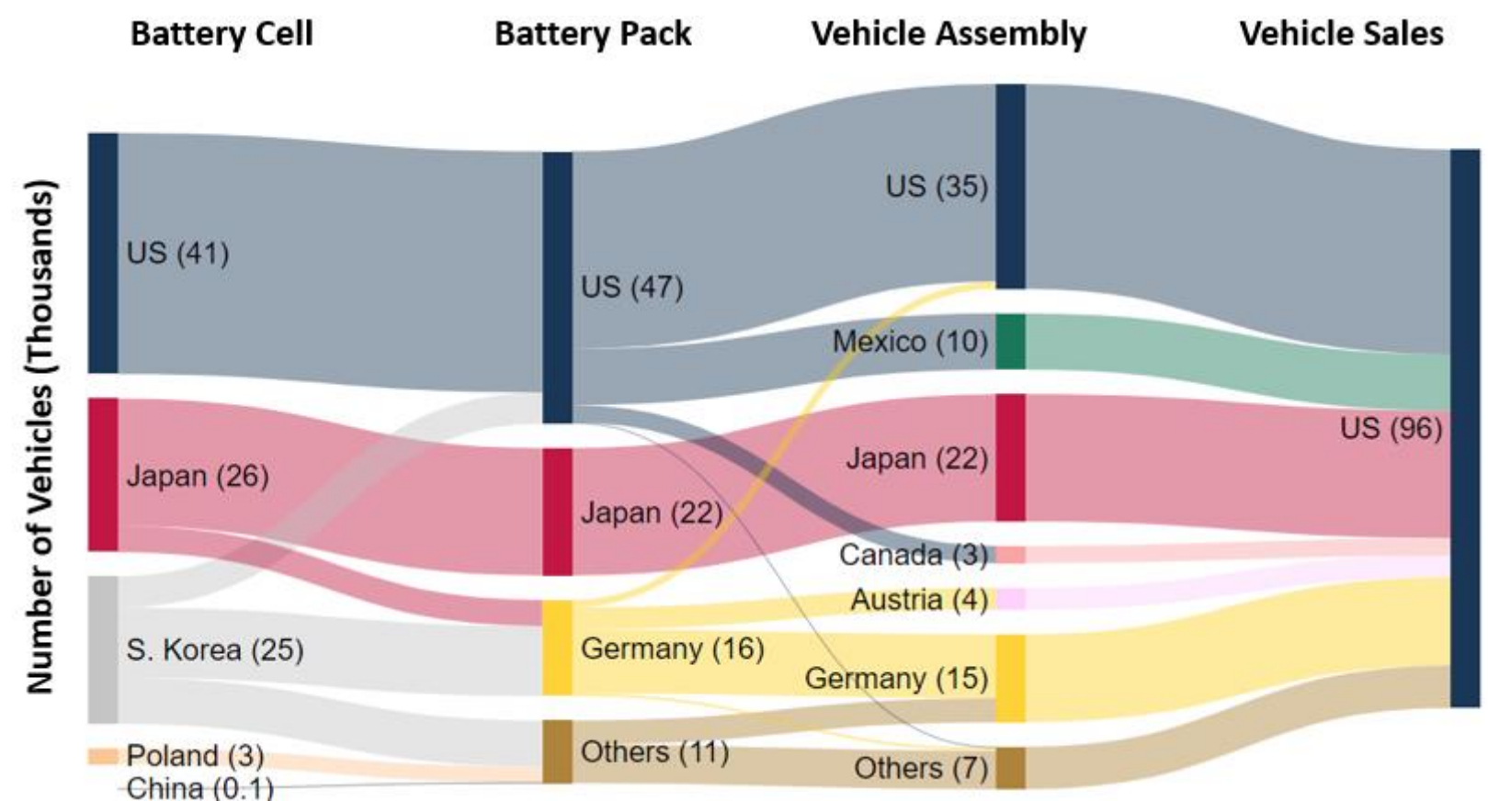

FIGURE A-77 2017 Number of battery packs (or vehicles) supplied to the U.S. PHEV market by production location. "Others" for battery pack includes Poland, S. Korea, Hungary, and China. "Others" for vehicle assembly includes Sweden, S. Korea, China and Netherlands. 


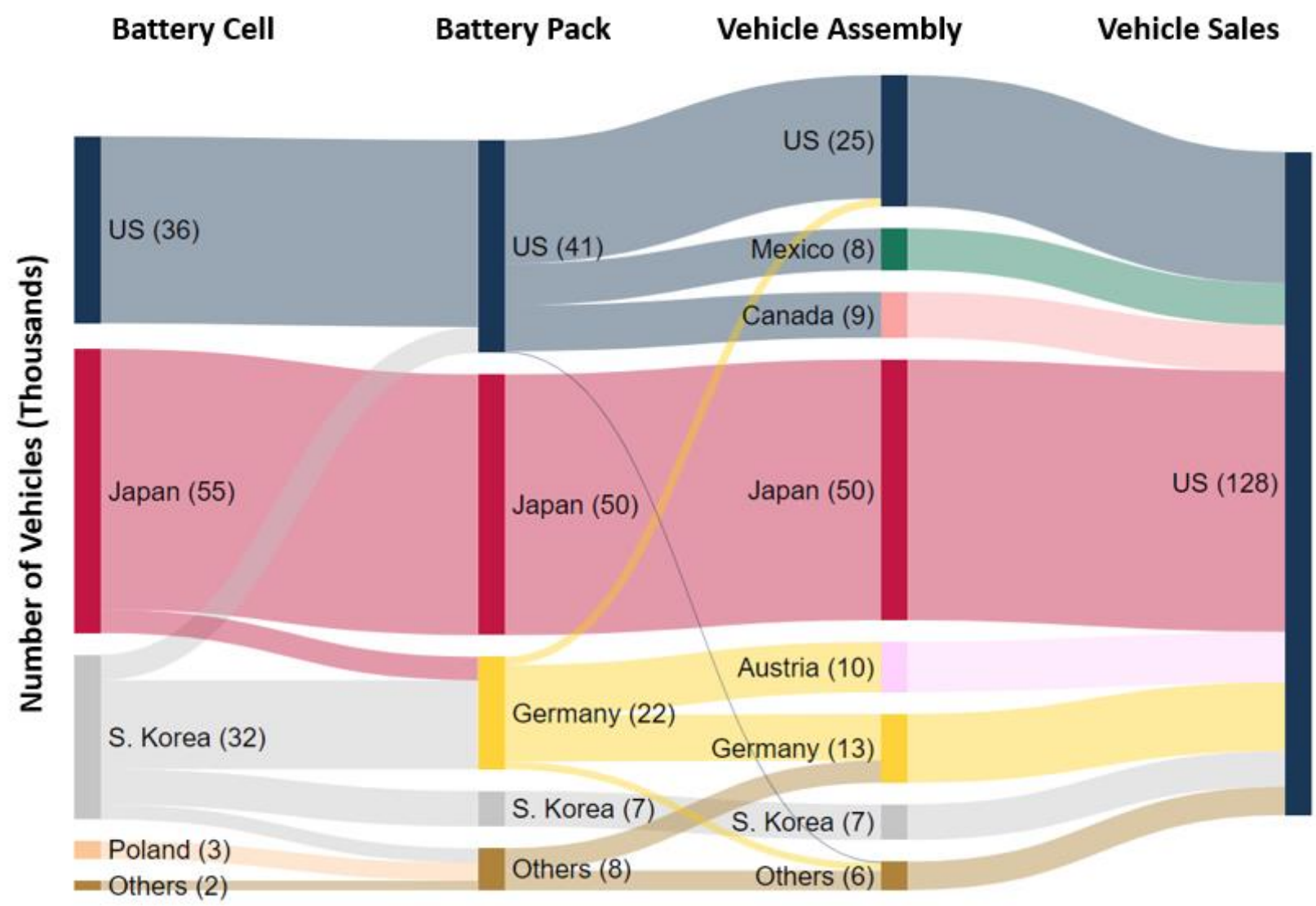

FIGURE A-78 2018 Number of battery packs (or vehicles) supplied to the U.S. PHEV market by production location. "Others" for battery cell includes Hungary and China. "Others" for battery pack includes Poland, Hungary, and China. "Others" for vehicle assembly includes Sweden, Netherlands, and China. 


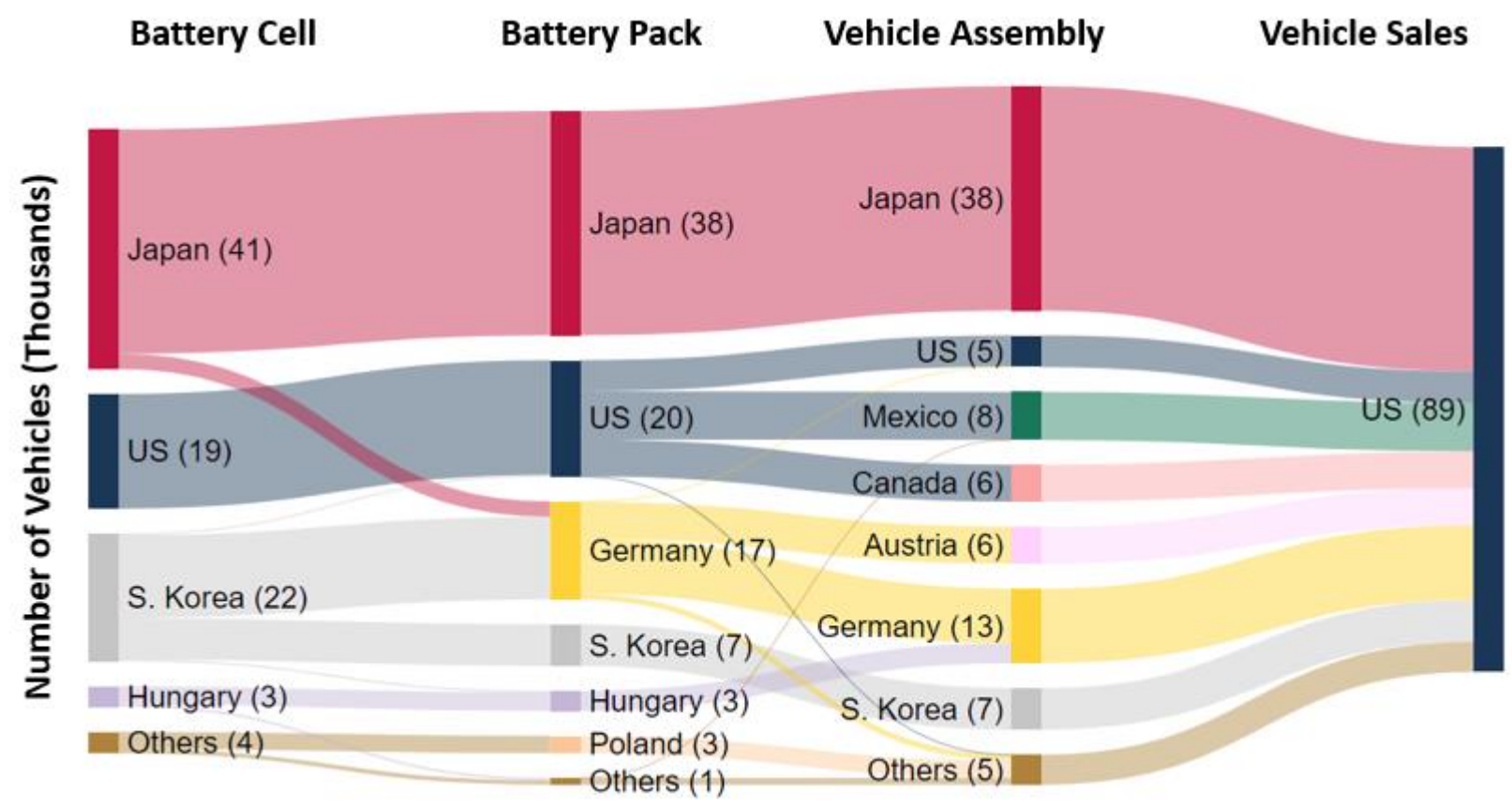

FIGURE A-79 2019 Number of battery packs (or vehicles) supplied to the U.S. PHEV market by production location. "Others" for battery cell includes Poland and China. "Others" for battery pack includes China, Belgium, United Kingdom. "Others" for vehicle assembly includes Sweden, Netherlands, China, Belgium, and United Kingdom.

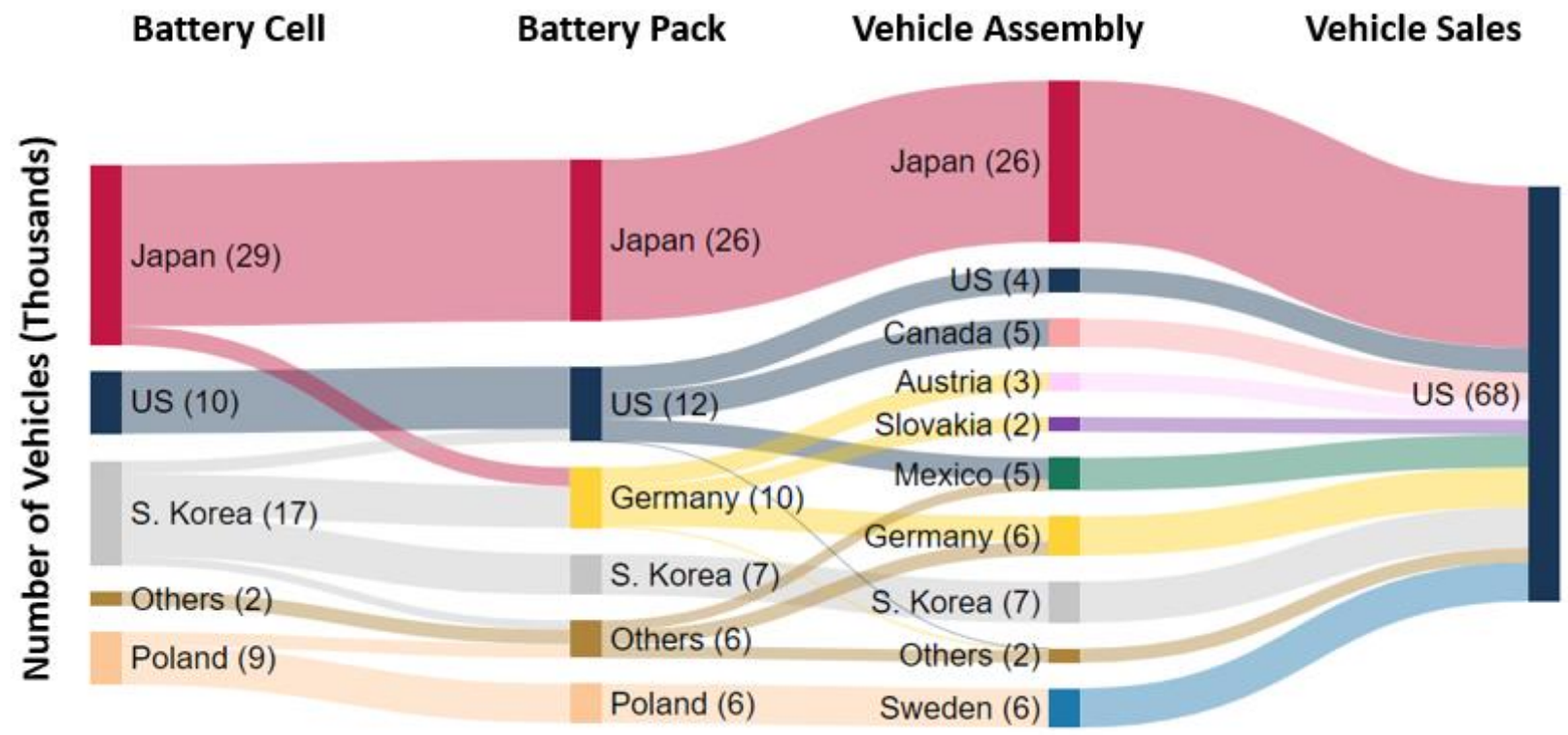

FIGURE A-80 2020 Number of battery packs (or vehicles) supplied to the U.S. PHEV market by production location. "Others" for battery cell includes Hungary and China. "Others" for battery pack includes Hungary, Belgium, United Kingdom, and China. "Others" for vehicle assembly includes Netherlands, Belgium, United Kingdom, and China. 


\section{APPENDIX B: VEHICLE MAKE AND MODEL DATA}

This appendix presents information about batteries in each make and model of plug-in electric vehicles and hybrids sold in the United States from 2010 through 2020. This information includes the cell manufacturer and pack manufacturer along with production country for each PEV, as well as the state for United States production, as shown in Table B-1 and Table B-2. The state for U.S. production is a best estimate based on the available sources, although there are several cases where we must assume a state based on the nearest known factory. The tables also present vehicle assembly location, per-vehicle battery capacity, and total cumulative sales of each model. Table B-3 presents the battery capacity and manufacturer for each model of hybrid with a Li-ion battery. For the HEV, model year is shown to match the FuelEconomy.gov database. 
TABLE B-1 BEV Battery Cell, Battery Pack Manufacturers and Vehicle Assembly Locations by Make and Model

\begin{tabular}{|c|c|c|c|c|c|c|c|c|c|}
\hline $\begin{array}{l}\text { Vehicle } \\
\text { Make }\end{array}$ & $\begin{array}{l}\text { Vehicle } \\
\text { Model }\end{array}$ & $\begin{array}{l}\text { Calendar } \\
\text { Year }\end{array}$ & Cell OEM & Pack OEM & $\begin{array}{l}\text { Cell Production } \\
\text { Location }\end{array}$ & $\begin{array}{c}\text { Pack } \\
\text { Production } \\
\text { Location }\end{array}$ & $\begin{array}{c}\text { Vehicle } \\
\text { Assembly } \\
\text { Location* }\end{array}$ & $\begin{array}{c}\text { Battery } \\
\text { Size } \\
(\mathrm{kWh})\end{array}$ & $\begin{array}{l}\text { Cumulative } \\
\text { Sales } \\
(2010- \\
2020, \\
\text { thousands) }\end{array}$ \\
\hline Audi & E-tron & $2019-2020$ & LG Chem $^{47,48,49}$ & LG Chem ${ }^{50}$ & Poland $^{51,52}$ & Belgium $^{53,54}$ & Belgium $^{55}$ & 95 & 12.6 \\
\hline BMW & Active E & 2012 & Samsung $^{56}$ & Bosch $^{57}$ & Korea $^{58}$ & Germany $^{59}$ & Germany $^{60}$ & 32 & 0.7 \\
\hline BMW & $\mathrm{i} 3$ & 2014-2018 & Samsung $^{61,62}$ & Samsung SDI ${ }^{63}$ & Korea $^{64,65}$ & Germany $^{66,67}$ & Germany $^{68}$ & $22-33$ & 10.4 \\
\hline BMW & $\mathrm{i} 3$ & $2018-2020$ & Samsung $^{69,70}$ & Samsung SDI & Hungary $^{71}$ & Hungary $^{72}$ & Germany & $33-42$ & 3.0 \\
\hline Chevrolet & Bolt & 2016-2019 & LG Chem $^{73,74}$ & LG Chem $^{75}$ & Korea $^{76,77}$ & MI ${ }^{\dagger}$ U.S. $^{78,79}$ & MI, U.S. ${ }^{80,81}$ & 60 & 50.2 \\
\hline Chevrolet & Bolt & $\begin{array}{l}2019:- \\
2020\end{array}$ & LG Chem & LG Chem & MI, U.S. ${ }^{82,83,84}$ & MI, U.S. ${ }^{85}$ & MI, U.S. & $60-66$ & 28.9 \\
\hline Chevrolet & Spark & 2013-2014 & $\mathrm{A} 123^{86}$ & $\mathrm{~A} 123^{87}$ & MI, U.S. ${ }^{88}$ & MI, U.S. ${ }^{89}$ & Korea $^{90,91}$ & 19 & 1.7 \\
\hline Chevrolet & Spark & $2015-2016$ & LG Chem $^{92}$ & LG Chem $^{93}$ & MI, U.S. ${ }^{94}$ & MI, U.S. ${ }^{95}$ & Korea $^{96}$ & 19 & 5.7 \\
\hline Fiat & $500 \mathrm{e}$ & 2013-2020 & Samsung 97,98 & Bosch $^{99,100}$ & MI ${ }^{\dagger}$ U.S. $^{101}$ & $\begin{array}{l}\text { MI, }{ }^{\dagger} \\
\text { U.S. }{ }^{102,103}\end{array}$ & Mexico $^{104}$ & 24 & 14.0 \\
\hline Ford & Focus EV & $2012-2013$ & LG Chem $^{105,106}$ & LG Chem $^{107}$ & Korea $^{108}$ & MI, ${ }^{\dagger}$ U.S. ${ }^{109}$ & MI, U.S. ${ }^{110}$ & 23 & 2.0 \\
\hline Ford & Focus EV & 2013-2018 & LG Chem $^{111,112}$ & LG Chem $^{113}$ & MI, U.S. ${ }^{114,115,116}$ & MI, U.S. ${ }^{117,118}$ & MI, U.S. ${ }^{119}$ & $23-34$ & 7.2 \\
\hline Ford & $\begin{array}{l}\text { Mustang } \\
\text { Mach E }\end{array}$ & 2020 & LG Chem $^{120,121}$ & LG Chem ${ }^{\#}$ & Poland ${ }^{122,123}$ & MI, U.S. ${ }^{\#}$ & Mexico $^{124}$ & 88 & 0.003 \\
\hline Honda & $\begin{array}{l}\text { Clarity } \\
\text { Electric }^{\S}\end{array}$ & $2017-2020$ & Panasonic $^{125}$ & Panasonic & Japan & Japan & $\mathrm{Japan}^{\mathrm{TI}}$ & 26 & 2.7 \\
\hline Honda & Fit EV & $2012-2014$ & Toshiba $^{126}$ & Toshiba $^{127}$ & Japan $^{128,129}$ & Japan & Japan $^{130}$ & 20 & 1.1 \\
\hline Hyundai & $\begin{array}{l}\text { Ioniq } \\
\text { Electric }\end{array}$ & $2017-2020$ & LG Chem $^{131}$ & LG Chem $^{132,133}$ & Korea $^{134, \diamond}$ & Korea & Korea $^{135}$ & $28-38$ & 4.1 \\
\hline Hyundai & $\begin{array}{l}\text { Kona } \\
\text { Electric }\end{array}$ & 2019-2020 & LG Chem $^{136,137}$ & LG Chem ${ }^{138}$ & Korea $^{139, \diamond}$ & Korea $^{140}$ & Korea $^{141}$ & 64 & 6.6 \\
\hline Jaguar & I-Pace & $2018-2020$ & LG Chem $^{142}$ & Jaguar $^{143,144}$ & Poland $^{145}$ & Poland $^{146}$ & Austria $^{147}$ & 90 & 4.4 \\
\hline $\mathrm{Kia}$ & $\begin{array}{l}\text { Niro } \\
\text { Electric } \\
\end{array}$ & 2019-2020 & $\begin{array}{l}\text { SK } \\
\text { Innovation }^{148,149}\end{array}$ & SK Innovation ${ }^{150}$ & Korea & Korea $^{151}$ & Korea $^{152}$ & 64 & 5.4 \\
\hline Kia & Soul EV & 2014-2018 & $\begin{array}{l}\text { SK } \\
\text { Innovation }^{153,154}\end{array}$ & SK Innovation ${ }^{155,156}$ & Korea $^{157,158}$ & Korea $^{159}$ & Korea $^{160}$ & $27-30$ & 6.3 \\
\hline Mercedes & $\begin{array}{l}\text { B-Class } \\
\text { Electric } \\
\text { Drive }\end{array}$ & 2014-2016 & Panasonic $^{161,162}$ & Tesla $^{163,164}$ & Japan & $\mathrm{CA},{ }^{\dagger} \mathrm{U} . \mathrm{S}$. & Germany ${ }^{165}$ & 28 & 3.3 \\
\hline
\end{tabular}


TABLE B-1 (Cont.)

\begin{tabular}{|c|c|c|c|c|c|c|c|c|c|}
\hline $\begin{array}{c}\text { Vehicle } \\
\text { Make }\end{array}$ & $\begin{array}{l}\text { Vehicle } \\
\text { Model }\end{array}$ & $\begin{array}{c}\text { Calendar } \\
\text { Year }\end{array}$ & Cell OEM & Pack OEM & $\begin{array}{c}\text { Cell } \\
\text { Production } \\
\text { Location }\end{array}$ & $\begin{array}{c}\text { Pack } \\
\text { Production } \\
\text { Location }\end{array}$ & $\begin{array}{c}\text { Vehicle } \\
\text { Assembly } \\
\text { Location* }\end{array}$ & $\begin{array}{l}\text { Battery } \\
\text { Size } \\
(\mathrm{kWh})\end{array}$ & $\begin{array}{c}\text { Cumulative } \\
\text { Sales } \\
(2010- \\
2020, \\
\text { thousands) }\end{array}$ \\
\hline Mercedes & $\begin{array}{l}\text { B-Class } \\
\text { Electric } \\
\text { Drive }\end{array}$ & $\begin{array}{l}2017^{166} \text { - } \\
2018\end{array}$ & SK Innovation ${ }^{167}$ & Accumotive $^{168}$ & Korea $^{169}$ & Germany ${ }^{170}$ & Germany & 28 & 0.9 \\
\hline MINI & $\begin{array}{l}\text { Cooper } \\
\text { SE }\end{array}$ & 2020 & Samsung^ & Samsung SDI^ & Korea & Germany $^{171}$ & U.K. ${ }^{172}$ & 33 & 0.4 \\
\hline Mitsubishi & I EV & $2011-2017$ & GS Yuasa $^{173}$ & GS Yuasa $^{174}$ & Japan & Japan $^{175}$ & $\operatorname{Japan}^{176,177}$ & 16 & 2.1 \\
\hline Nissan & Leaf & $2010-2012$ & AESC & $\mathrm{AESC}^{178}$ & Japan $^{\Delta}$ & Japan $^{\Delta}$ & Japan $^{179}$ & 24 & 19.5 \\
\hline Nissan & Leaf & $2013-2020$ & $\mathrm{AESC}^{180,181}$ & $\mathrm{AESC}^{182,183}$ & TN, U.S. ${ }^{184,185}$ & TN, U.S. ${ }^{186,187}$ & TN, U.S. ${ }^{188,189}$ & $24-62$ & 132.0 \\
\hline Polestar & 2 & 2020 & LG Chem $^{190}$ & LG Chem $^{191}$ & China ${ }^{*}$ & China ${ }^{*}$ & China $^{192}$ & 78 & 0.1 \\
\hline Porsche & Taycan & $2019-2020$ & LG Chem $^{193}$ & Draexlmaier $^{194,195}$ & Korea $^{196}$ & Germany $^{197}$ & Germany $^{198}$ & 93 & 4.5 \\
\hline Smart & ED & $2011-2015$ & Li-tec ${ }^{199}$ & Accumotive 200 & Germany $^{201}$ & Germany $^{202}$ & France & $17-18$ & 5.4 \\
\hline Smart & ED & $2016-2019$ & LG Chem ${ }^{203,204}$ & Accumotive 205 & Korea & Germany $^{206}$ & France $^{207}$ & 18 & 3.1 \\
\hline Tesla & Model 3 & $2017-2020$ & Panasonic $^{208,209}$ & Tesla $^{210}$ & NV, U.S. ${ }^{211,212}$ & NV, U.S. ${ }^{213}$ & CA, U.S. ${ }^{214,215}$ & $54-75$ & 355.7 \\
\hline Tesla & Model S & $2012-2020$ & Panasonic ${ }^{216,217}$ & Tesla $^{218}$ & Japan $^{219,220}$ & $\mathrm{CA}^{\dagger}{ }^{\dagger} \mathrm{U}_{\mathrm{SS}}{ }^{22 l}$ & CA, U.S. ${ }^{222}$ & $60-100$ & 176.6 \\
\hline Tesla & Model X & $2015-2020$ & Panasonic $^{223,224}$ & Tesla $^{225}$ & Japan $^{226,227}$ & $\mathrm{CA}^{\dagger}{ }^{\dagger} \mathrm{U} \mathrm{S}^{2}{ }^{228}$ & CA, U.S. ${ }^{229}$ & $60-100$ & 99.5 \\
\hline Tesla & Model Y & 2020 & Panasonic $^{230}$ & Tesla & NV, U.S. ${ }^{231}$ & NV, ${ }^{\dagger}$ U.S. & CA, U.S. ${ }^{232,233}$ & 75 & 58.2 \\
\hline Toyota & $\begin{array}{l}\text { RAV4 } \\
\text { EV }\end{array}$ & 2012-2014 & Panasonic & Tesla $^{234,235}$ & Japan & $\mathrm{CA},{ }^{\dagger} \mathrm{U} \mathrm{S} .{ }^{236}$ & Canada $^{237}$ & 42 & 2.4 \\
\hline Volkswagen & e-golf & $2014-2016$ & Panasonic $^{238}$ & Sanyo $^{239}$ & Korea & Germany $^{240}$ & Germany $^{241}$ & 24 & 8.5 \\
\hline Volkswagen & e-golf & $2017-2020$ & Samsung $^{242,243}$ & Samsung SDI ${ }^{244}$ & Korea $^{245}$ & Hungary $^{246,247}$ & Germany $^{202}$ & 24 & 10.5 \\
\hline
\end{tabular}

* Vehicle assembly locations are from AALA unless cited otherwise. AALA was consulted for all models [248]

$\dagger$ USA state location is best estimate based on nearest known factory

$\$$ For the Chevy Bolt, we assume that the 50,932 recalled vehicles in the U.S. had cells produced in Korea and the remainder in the U.S. [249,250]

\# For the Ford Mustang MACH E battery pack OEM and location, we assume the same as other Ford vehicles

$\S$ Data are limited for the Honda Clarity BEV; unless cited otherwise, we assume the same as Honda Clarity PHEV

II A VIN search for the Honda Clarity BEV shows the 11th digit ' $\mathrm{C}$ ', implying assembly at Sayama plant in Japan

$\diamond \quad$ For the Hyundai Ioniq EV and Kona EV, cell production may be in Nanjing, China [251,252]

$\wedge$ For the MINI Cooper SE, unless otherwise cited, we assume the same OEM as the MINI Countryman SE PHEV

$\Delta$ For the early Nissan Leaf models, we assume that the battery cell and pack locations are the same as the assembly location

t+ For the Polestar 2, we assume the same location as the Volvo S90, which is also the closest LG Chem plant to the assembly location 
TABLE B-2 PHEV Battery Cell, Battery Pack Manufacturers and Vehicle Assembly Locations by Make and Model

\begin{tabular}{|c|c|c|c|c|c|c|c|c|c|}
\hline $\begin{array}{l}\text { Vehicle } \\
\text { Make }\end{array}$ & Vehicle Model & $\begin{array}{c}\text { Calendar } \\
\text { Year }\end{array}$ & Cell OEM & Pack OEM & $\begin{array}{c}\text { Cell Production } \\
\text { Location }\end{array}$ & $\begin{array}{c}\text { Pack } \\
\text { Production } \\
\text { Location }\end{array}$ & $\begin{array}{l}\text { Vehicle } \\
\text { Assembly } \\
\text { Location* }\end{array}$ & $\begin{array}{c}\text { Battery } \\
\text { Size } \\
(\mathrm{kWh})\end{array}$ & $\begin{array}{c}\text { Cumulative } \\
\text { Sales (2010- } \\
2020, \\
\text { thousands) }\end{array}$ \\
\hline Audi & A3 Plug-in & 2016-2019 & Panasonic $^{253}$ & Panasonic $^{254}$ & Japan $^{255}$ & Germany & Germany $^{256}$ & 9 & 9.6 \\
\hline Audi & A8 Plug-in & 2020 & LG Chem $^{257}$ & LG Chem & Poland & Belgium $^{258}$ & Germany $^{259}$ & 14 & 0.03 \\
\hline Audi & Q5 & $2019-2020$ & LG Chem $^{260}$ & LG Chem & Poland $^{261}$ & Belgium $^{262}$ & Mexico $^{263}$ & 14 & 1.7 \\
\hline BMW & 3-Series Plug-in & $2016-2020$ & Samsung & Samsung SDI ${ }^{264}$ & Korea $^{265}$ & Hungary ${ }^{266}$ & Germany $^{267}$ & 8 & 9.6 \\
\hline BMW & 5-Series Plug-in & $2017-2020$ & Samsung 268 & BMW Group 269 & Korea $^{270}$ & Germany $^{271}$ & Austria $^{272}$ & $9-12$ & 22.8 \\
\hline BMW & 7-Series Plug-in & $2016-2020$ & Samsung $^{273}$ & Samsung SDI ${ }^{274}$ & Korea $^{275}$ & Germany $^{276}$ & Germany $^{277}$ & $9-12$ & 1.6 \\
\hline BMW & i3 $\mathrm{REx}^{\#}$ & 2014-2018 & Samsung & Samsung SDI & Korea & Germany & Germany & $22-33$ & 24.6 \\
\hline BMW & i3 $\mathrm{REx}^{\#}$ & $2018-2020$ & Samsung & Samsung SDI & Hungary & Hungary & Germany & $33-42$ & 5.5 \\
\hline BMW & i8 & $2014-2020$ & Samsung $^{278}$ & Samsung SDI ${ }^{279}$ & Korea & Germany $^{280}$ & Germany $^{281}$ & $7-12$ & 7.0 \\
\hline BMW & X3 & 2020 & Samsung $^{282}$ & BMW Group $^{283,284}$ & Korea $^{285}$ & SC, U.S. ${ }^{286,287}$ & SC, U.S. ${ }^{288}$ & 12 & 0.9 \\
\hline BMW & X5 & $2015-2020$ & Samsung 289,290 & BMW Group $^{291,292}$ & Korea $^{293}$ & SC, U.S. ${ }^{294,295}$ & \begin{tabular}{|l} 
SC, \\
U.S. ${ }^{296,297}$ \\
\end{tabular} & $9-24$ & 18.7 \\
\hline Cadillac & CT6 & $2017-2018$ & LG Chem $^{298}$ & LG Chem & MI, ${ }^{\dagger}$ U.S. ${ }^{299}$ & MI, U.S. ${ }^{300,301}$ & China $^{302}$ & 18 & 0.5 \\
\hline Cadillac & ELR & 2013-2016 & LG Chem $^{303}$ & LG Chem $^{304}$ & MI, U.S. ${ }^{305}$ & MI, U.S. ${ }^{306,307}$ & MI, U.S. ${ }^{308}$ & 17 & 2.9 \\
\hline Chevrolet & Volt & $2010-2013$ & LG Chem $^{309}$ & LG Chem $^{310}$ & Korea $^{311}$ & MI, U.S. ${ }^{312}$ & MI, U.S. & 16 & 48.2 \\
\hline Chevrolet & Volt & 2013-2019 & LG Chem ${ }^{313}$ & LG Chem 314,315 & MI, U.S. ${ }^{316,317}$ & MI, U.S. ${ }^{318}$ & \begin{tabular}{|l|} 
MI, \\
U.S. ${ }^{319,320}$ \\
\end{tabular} & $17-18$ & 108.8 \\
\hline Chrysler & $\begin{array}{l}\text { Pacifica Plug-in } \\
\text { Hybrid }\end{array}$ & $2017-2020$ & LG Chem ${ }^{321}$ & LG Chem ${ }^{322}$ & MI, U.S. ${ }^{323}$ & MI, U.S. ${ }^{324,325}$ & Canada $^{326}$ & 16 & 22.7 \\
\hline Ford & C-Max Energi & 2012-2018 & Panasonic ${ }^{327}$ & Panasonic ${ }^{328}$ & MI, ${ }^{\dagger}$ U.S. ${ }^{329}$ & MI, U.S. ${ }^{330}$ & MI, U.S. ${ }^{331}$ & 8 & 42.2 \\
\hline Ford & Fusion Energi & 2013-2020 & $\begin{array}{l}\text { Panasonic } \\
333\end{array}$ & Panasonic 334 & $\mathrm{MI},{ }^{\dagger} \mathrm{U} . \mathrm{S}$. & MI, U.S. ${ }^{335}$ & Mexico $^{336,337}$ & 8 & 72.8 \\
\hline Honda & Accord PHEV & 2013-2015 & Blue Energy $^{338}$ & Blue Energy ${ }^{339}$ & Japan $^{340}$ & Japan & Japan $^{341}$ & 7 & 1.0 \\
\hline Honda & Clarity Plug-in ${ }^{\S}$ & $2017-2020$ & Panasonic ${ }^{342}$ & Panasonic ${ }^{343}$ & Japan & Japan & Japan $^{344}$ & 17 & 34.2 \\
\hline Hyundai & Ioniq Plug-in & $2018-2020$ & LG Chem $^{345}$ & LG Chem & Korea $^{346}$ & Korea & Korea $^{347}$ & 9 & 7.8 \\
\hline Hyundai & Sonata Plug-in & $2015-2020$ & LG Chem ${ }^{348}$ & LG Chem $^{349,350}$ & Korea $^{351}$ & Korea & Korea $^{352}$ & 10 & 6.7 \\
\hline Jeep & Wrangler $\mathrm{PHEV}^{\wedge}$ & 2020 & LG Chem & LG Chem & MI, U.S. & MI, U.S. & OH, U.S. ${ }^{353}$ & 17 & 0.1 \\
\hline Kia & Niro Plug-in ${ }^{\Delta}$ & $2018-2020$ & \begin{tabular}{|l} 
SK \\
Innovation \\
\end{tabular} & SK Innovation 355 & Korea ${ }^{356}$ & Korea & Korea ${ }^{357}$ & 9 & 10.1 \\
\hline Kia & Optima Plug-in & $2017-2020$ & SK Innovation & LG Chem $^{358}$ & Korea & Korea $^{359}$ & Korea $^{360}$ & 10 & 2.8 \\
\hline
\end{tabular}


TABLE B-2 (Cont.)

\begin{tabular}{|c|c|c|c|c|c|c|c|c|c|}
\hline $\begin{array}{l}\text { Vehicle } \\
\text { Make }\end{array}$ & Vehicle Model & $\begin{array}{l}\text { Calendar } \\
\text { Year }\end{array}$ & Cell OEM & Pack OEM & $\begin{array}{c}\text { Cell Production } \\
\text { Location }\end{array}$ & $\begin{array}{c}\text { Pack } \\
\text { Production } \\
\text { Location }\end{array}$ & $\begin{array}{c}\text { Vehicle } \\
\text { Assembly } \\
\text { Location* }\end{array}$ & $\begin{array}{l}\text { Battery } \\
\text { Size } \\
(\mathrm{kWh})\end{array}$ & $\begin{array}{c}\text { Cumulative } \\
\text { Sales (2010- } \\
2020, \\
\text { thousands) }\end{array}$ \\
\hline $\begin{array}{l}\text { Land } \\
\text { Rover }\end{array}$ & $\begin{array}{l}\text { Range Rover } \\
\text { Plug-in, Range } \\
\text { Rover Sport } \\
\text { Plug-in }\end{array}$ & 2019-2020 & Samsung ${ }^{361,362}$ & Jaguar $^{363}$ & Hungary ${ }^{364}$ & U.K. ${ }^{365}$ & U.K. ${ }^{366}$ & 13 & 1.8 \\
\hline Lincoln & Aviator Plug-in & 2019-2020 & LG Chem $^{367}$ & LG Chem $^{368}$ & MI,$^{\dagger}$ U.S. & MI, ${ }^{\dagger}$ U.S. & IL, U.S. ${ }^{369,370}$ & 14 & 1.9 \\
\hline Mercedes & C350We & 2016-2020 & $\begin{array}{l}\text { SK } \\
\text { Innovation }^{371,372} \\
\end{array}$ & Accumotive $^{373}$ & Korea $^{374}$ & Germany $^{375,376}$ & AL, U.S. ${ }^{377}$ & 6 & 1.9 \\
\hline Mercedes & GLC350e & 2018-2020 & $\begin{array}{l}\text { SK } \\
\text { Innovation }^{378,379}\end{array}$ & Accumotive $^{380}$ & Korea $^{381}$ & Germany $^{382,383}$ & $\begin{array}{l}\text { Germany } \\
385\end{array}$ & $9-14$ & 8.8 \\
\hline Mercedes & GLE 550e & 2016-2019 & $\begin{array}{l}\text { SK } \\
\text { Innovation }^{386,387} \\
\end{array}$ & Accumotive $^{388}$ & Korea $^{389}$ & Germany $^{390,391}$ & AL, U.S. ${ }^{392}$ & 9 & 1.4 \\
\hline Mercedes & S550 Plug-in & 2015-2018 & $\begin{array}{l}\text { SK } \\
\text { Innovation }^{393,394} \\
\end{array}$ & Accumotive ${ }^{395,396}$ & Korea ${ }^{397}$ & Germany & Germany ${ }^{398}$ & 6 & 1.4 \\
\hline MINI & Countryman S E & 2017-2020 & Samsung & Samsung SDI & Korea & Germany & $\begin{array}{l}\text { Netherlands } \\
399\end{array}$ & $8-10$ & 3.2 \\
\hline Mitsubishi & Outlander Plug-in & $2018-2020$ & GS Yuasa 400 & GS Yuasa $^{401}$ & Japan $^{402}$ & Japan $^{403}$ & Japan $^{404}$ & 12 & 8.9 \\
\hline Polestar & 1 & 2020 & LG Chem ${ }^{405}$ & \begin{tabular}{|l|} 
LG Chem $^{406}$ \\
\end{tabular} & China $^{\wedge \wedge}$ & China $^{\wedge \wedge}$ & China $^{407}$ & 34 & 0.01 \\
\hline Porsche & $\begin{array}{l}\text { Cayenne E- } \\
\text { Hybrid }\end{array}$ & 2014-2019 & Panasonic 408 & Bosch $^{409}$ & Japan & Germany & Germany 410 & 11 & 7.3 \\
\hline Porsche & $\begin{array}{l}\text { Cayenne E- } \\
\text { Hybrid }\end{array}$ & $2020^{\S \S}$ & Panasonic & Bosch & Japan & Germany & Slovakia $^{411}$ & 14 & 2.4 \\
\hline Porsche & $\begin{array}{l}\text { Panamera E- } \\
\text { Hybrid }^{\text {IIII }} \\
\end{array}$ & 2013-2020 & Panasonic ${ }^{412}$ & Bosch $^{413}$ & Japan & Germany & Germany ${ }^{414}$ & $9-14$ & 4.8 \\
\hline Subaru & $\begin{array}{l}\text { Crosstrek } \\
\text { Hybrid }^{\Delta \Delta} \\
\end{array}$ & 2019-2020 & Panasonic & Panasonic & Japan & Japan & Japan & 9 & 5.1 \\
\hline Toyota & Prius PHEV & $2012-2016$ & Panasonic 415 & $\begin{array}{l}\text { Primearth EV } \\
\text { Energy }^{416}\end{array}$ & Japan $^{417}$ & Japan & $\operatorname{Japan}^{418}$ & 4 & 42.3 \\
\hline Toyota & $\begin{array}{l}\text { Prius Prime } \\
\text { PHEV }\end{array}$ & 2016-2020 & Panasonic & Panasonic 419 & Japan $^{420}$ & Japan $^{421}$ & Japan & 9 & 87.5 \\
\hline Toyota & RAV4 Prime $^{\diamond \diamond}$ & 2020 & Panasonic & Panasonic & Japan & Japan & Japan $^{422}$ & 18 & 3.2 \\
\hline Volvo & S90 Plug-in & $2017-2020$ & LG Chem $^{423}$ & LG Chem $^{424}$ & China $^{425}$ & China & China $^{426}$ & $9-10$ & 0.8 \\
\hline Volvo & V60 Plug-in & 2019-2020 & LG Chem $^{427}$ & LG Chem $^{428}$ & Poland $^{429}$ & Belgium $^{430}$ & Belgium $^{431}$ & 12 & 1.0 \\
\hline
\end{tabular}


TABLE B-2 (Cont.)

\begin{tabular}{|c|c|c|c|c|c|c|c|c|c|}
\hline $\begin{array}{l}\text { Vehicle } \\
\text { Make }\end{array}$ & Vehicle Model & $\begin{array}{l}\text { Calendar } \\
\text { Year }\end{array}$ & Cell OEM & Pack OEM & $\begin{array}{l}\text { Cell Production } \\
\text { Location }\end{array}$ & $\begin{array}{c}\text { Pack } \\
\text { Production } \\
\text { Location }\end{array}$ & $\begin{array}{l}\text { Vehicle } \\
\text { Assembly } \\
\text { Location* }\end{array}$ & $\begin{array}{l}\text { Battery } \\
\text { Size } \\
(\mathrm{kWh})\end{array}$ & $\begin{array}{c}\text { Cumulative } \\
\text { Sales (2010- } \\
2020, \\
\text { thousands) }\end{array}$ \\
\hline Volvo & XC60 Plug-in & $2017-2020$ & LG Chem $^{432}$ & LG Chem $^{433,434}$ & Poland ${ }^{435}$ & Poland $^{436}$ & Sweden ${ }^{437}$ & $10-12$ & 6.5 \\
\hline Volvo & XC90 Plug-in & $2015-2020$ & LG Chem $^{438}$ & LG Chem $^{439,440}$ & Poland $^{441}$ & Poland $^{442}$ & Sweden $^{443}$ & $9-10$ & 11.0 \\
\hline
\end{tabular}

* Vehicle assembly locations are from AALA unless cited otherwise. AALA was consulted for all models [444]

$\dagger$ USA state location is best estimate based on nearest known factory

* No references available for the Audi A3 Plug-in battery pack location, so we assume that it is close to the assembly location

\# For the BMW i3 REx, we assume the same OEMs and locations as the i3 BEV

$\S$ Data are limited for the Honda Clarity PHEV; we use the available sources to form our assumptions. The batteries may be produced by Blue Energy, as indicated by a comment in [445]

II We assume that the Hyundai Ioniq PHEV is the same as the Ioniq EV unless otherwise cited

$\wedge$ For the Jeep Wrangler battery pack and cell OEM and location, we assume the same as the Chrysler Pacifica PHEV [446]

$\Delta$ For the Kia Niro PHEV, we assume the battery OEMs and locations are the same as the Niro BEV

$\diamond \quad$ Data are limited for the Kia Optima PHEV. Where sources are unavailable, we make assumptions based on other Kia models

\$t For the Mini Countryman S E, we assume the battery OEMs and locations are the same as other BMW vehicles

$\wedge \wedge$ For the Polestar 1, we assume the same location as the Volvo S90, which is also the closest LG Chem plant to the assembly location

$\S \S$ Note that while Automobilemag indicates that the 2019 Porsche Cayenne E-Hybrid is assembled in Slovakia, we use the AALA, which indicates that 2020 is the first year in which it was assembled in Slovakia

III We combine several Porsche Panamera E-Hybrid models since the available sales data is aggregated as such

$\Delta \Delta$ We assume that the Subaru Crosstrek PHEV is produced by the same OEMs in the same locations as the Toyota Prius Prime [447,448]

$\diamond \diamond$ One source indicates that the Toyota RAV4 Prime PHEV sources batteries from Prime Planet Energy \& Solutions [449]. However, according to official documentation, Prime Planet will not begin producing batteries until 2022; as such, we assume that Panasonic will supply batteries in the meantime [450] 
TABLE B-3 Li-Ion HEV Battery Cell, Battery Pack Manufacturers and Vehicle Assembly Locations by Make and Model

\begin{tabular}{|c|c|c|c|c|c|}
\hline Vehicle Make & Vehicle Model & Model Year & Battery Size (kWh) & Pack Manufacturer & Hybrid Type \\
\hline Acura & ILX Hybrid & 2013-2014 & 0.7 & Blue Energy & Mild \\
\hline Acura & MDX Hybrid & 2017-2018 & 1.3 & Blue Energy & Full \\
\hline Acura & NSX Hybrid & 2017-2021 & 1.3 & Blue Energy & Full \\
\hline Acura & RLX Hybrid & 2014-2020 & 1.3 & Blue Energy & Full \\
\hline Audi & A4 & 2021 & 0.5 & LG Chem & Mild \\
\hline Audi & A5 & 2021 & 0.5 & LG Chem & Mild \\
\hline Audi & A6 & 2020-2021 & 0.8 & LG Chem & Mild \\
\hline Audi & A7 & 2019-2021 & 0.8 & LG Chem & Mild \\
\hline Audi & A8 & 2019-2021 & 0.5 & LG Chem & Mild \\
\hline Audi & Q5 & 2013-2016 & 1.3 & Sanyo & Full \\
\hline Audi & Q7 & 2020-2021 & 0.5 & LG Chem & Mild \\
\hline Audi & Q8 & 2019-2021 & 0.9 & LG Chem & Mild \\
\hline Audi & RS 6 Avant & 2021 & 0.9 & LG Chem & Mild \\
\hline Audi & RS 7 & 2021 & 0.9 & LG Chem & Mild \\
\hline Audi & RS Q8 & 2020-2021 & 0.9 & LG Chem & Mild \\
\hline Audi & S6 & 2020-2021 & 0.8 & LG Chem & Mild \\
\hline Audi & S7 & 2020-2021 & 0.8 & LG Chem & Mild \\
\hline Audi & S8 & 2020-2021 & 0.5 & LG Chem & Mild \\
\hline BMW & 530i xDrive & 2021 & 0.5 & BMW Group & Mild \\
\hline BMW & $540 \mathrm{i}$ & 2021 & 0.5 & BMW Group & Mild \\
\hline BMW & ActiveHybrid 3 & 2013-2014 & 1.3 & A123 & Full \\
\hline BMW & ActiveHybrid 5 & 2015 & 1.4 & A123 & Full \\
\hline BMW & ActiveHybrid 5 & 2012-2015 & 0.7 & A123 & Full \\
\hline BMW & ActiveHybrid 7 & 2011-2012 & 0.4 & $\begin{array}{l}\text { Johnson Controls } \\
+ \text { Saft ABS }\end{array}$ & Mild \\
\hline BMW & ActiveHybrid 7L & 2013-2015 & 1.0 & $\begin{array}{l}\text { Johnson Controls } \\
+ \text { Saft ABS }\end{array}$ & Full \\
\hline BMW & M340i & 2021 & 0.5 & BMW Group & Mild \\
\hline
\end{tabular}


TABLE B-3 (Cont.)

\begin{tabular}{|c|c|c|c|c|c|}
\hline Vehicle Make & Vehicle Model & Model Year & Battery Size (kWh) & Pack Manufacturer & Hybrid Type \\
\hline BMW & X5 sDrive40i & 2021 & 0.5 & BMW Group & Mild \\
\hline BMW & $\mathrm{X} 7 \mathrm{xDrive} 40 \mathrm{i}$ & 2021 & 0.5 & BMW Group & Mild \\
\hline Buick & LaCrosse eAssist & $2012-2016$ & 0.5 & Hitachi & Mild \\
\hline Buick & LaCrosse eAssist & 2018-2019 & 0.4 & Hitachi & Mild \\
\hline Buick & Regal eAssist & $2012-2016$ & 0.5 & Hitachi & Mild \\
\hline Chevrolet & Impala eAssist & 2014 & 0.5 & Hitachi & Mild \\
\hline Chevrolet & Malibu eAssist & 2013-2014 & 0.5 & Hitachi & Mild \\
\hline Chevrolet & Malibu Hybrid & 2016-2019 & 1.5 & Hitachi & Full \\
\hline Chevrolet & Silverado 15 Hybrid 2WD & 2016-2018 & 0.4 & Hitachi & Mild \\
\hline Ford & C-MAX Hybrid FWD & 2013-2018 & 1.4 & Panasonic & Full \\
\hline Ford & Escape & 2020 & 1.1 & Vehicle Energy Japan & Full \\
\hline Ford & Explorer & $2020-2021$ & 1.5 & Vehicle Energy Japan & Full \\
\hline Ford & F150 Pickup 4WD HEV & 2021 & 1.5 & Vehicle Energy Japan & Full \\
\hline Ford & Fusion Hybrid FWD & 2013-2020 & 1.4 & Panasonic & Full \\
\hline GMC & Sierra & 2016-2018 & 0.4 & Hitachi & Mild \\
\hline Honda & Accord Hybrid & 2014-2021 & 1.3 & Blue Energy & Full \\
\hline Honda & Civic Hybrid & 2012-2015 & 1.0 & Blue Energy & Mild \\
\hline Honda & CR-V Hybrid AWD & 2020-2021 & 1.4 & Honda - Panasonic & Full \\
\hline Honda & CR-Z & 2013-2016 & 0.7 & Blue Energy & Mild \\
\hline Honda & Insight & 2019-2021 & 1.1 & Honda - Panasonic & Full \\
\hline Hyundai & Elantra & 2021 & 1.3 & LG Chem & Full \\
\hline Hyundai & Ioniq & 2017-2021 & 1.6 & LG Chem & Full \\
\hline Hyundai & Sonata & 2011-2015 & 1.4 & LG Chem & Full \\
\hline Hyundai & Sonata & 2016-2017 & 1.6 & LG Chem & Full \\
\hline Hyundai & Sonata & 2018-2021 & 1.8 & LG Chem & Full \\
\hline Infiniti & $\mathrm{M} 35 \mathrm{~h}$ & $2012-2013$ & 1.4 & AESC & Full \\
\hline Infiniti & Q50 Hybrid & 2014-2018 & 1.4 & AESC & Full \\
\hline
\end{tabular}


TABLE B-3 (Cont.)

\begin{tabular}{|c|c|c|c|c|c|}
\hline Vehicle Make & Vehicle Model & Model Year & Battery Size (kWh) & Pack Manufacturer & Hybrid Type \\
\hline Infiniti & 2014-2018 & $2014-2018$ & 1.4 & AESC & Full \\
\hline Infiniti & QX60 Hybrid AWD & 2014-2017 & 0.7 & Hitachi & Mild \\
\hline Jeep & Wrangler 4WD & 2018-2021 & 0.4 & LG Chem & Mild \\
\hline Kia & Niro & $2017-2020$ & 1.6 & LG Chem & Full \\
\hline Kia & Optima Hybrid & 2011-2016 & 1.4 & LG Chem & Full \\
\hline Kia & Optima Hybrid & 2017-2021 & 1.6 & LG Chem & Full \\
\hline Kia & Sorento Hybrid & 2021 & 1.5 & LG Chem & Full \\
\hline Land Rover & Defender & 2020-2021 & 0.2 & Jaguar Land Rover & Mild \\
\hline Land Rover & Evoque MHEV & 2020 & 0.2 & Jaguar Land Rover & Mild \\
\hline Land Rover & Range Rover MHEV & 2019-2021 & 0.2 & Jaguar Land Rover & Mild \\
\hline Lexus & ES 300h & 2021 & 1.0 & Primearth EV Energy & Full \\
\hline Lexus & LC 500h & 2018-2021 & 1.1 & Primearth EV Energy & Full \\
\hline Lincoln & MKZ Hybrid & 2014-2020 & 1.4 & Panasonic & Full \\
\hline Mercedes-Benz & AMG CLS53 4matic Plus & 2019-2021 & 0.9 & Accumotive & Mild \\
\hline Mercedes-Benz & AMG E53 4matic Plus & 2019-2021 & 0.9 & Accumotive & Mild \\
\hline Mercedes-Benz & AMG GLE53 4matic Plus & 2021 & 0.9 & Accumotive & Mild \\
\hline Mercedes-Benz & AMG GLS63 4matic Plus & 2021 & 0.9 & Accumotive & Mild \\
\hline Mercedes-Benz & AMG GT 43 4matic Plus & 2021 & 0.9 & Accumotive & Mild \\
\hline Mercedes-Benz & AMG GT 53 4matic Plus & 2019-2021 & 0.9 & Accumotive & Mild \\
\hline Mercedes-Benz & CLS450 & 2019-2021 & 0.9 & Accumotive & Mild \\
\hline Mercedes-Benz & E400 Hybrid & 2013-2015 & 0.8 & Johnson Controls & Full \\
\hline Mercedes-Benz & E450 & 2021 & 0.9 & Accumotive & Mild \\
\hline Mercedes-Benz & GLE450 4matic & 2020-2021 & 0.9 & Accumotive & Mild \\
\hline Mercedes-Benz & GLE580 4matic & 2020-2021 & 0.9 & Accumotive & Mild \\
\hline Mercedes-Benz & GLS600 4matic & 2021 & 0.9 & Accumotive & Mild \\
\hline Mercedes-Benz & S400 Hybrid & 2010-2013 & 0.8 & $\begin{array}{l}\text { Johnson Controls } \\
+ \text { Saft ABS } \\
\end{array}$ & Mild \\
\hline
\end{tabular}


TABLE B-3 (Cont.)

\begin{tabular}{|l|l|l|l|l|l|}
\hline Vehicle Make & Vehicle Model & Model Year & Battery Size $(\mathrm{kWh})$ & Pack Manufacturer & Hybrid Type \\
\hline Nissan & Murano Hybrid & 2016 & 0.7 & Hitachi & Mild \\
\hline Nissan & Pathfinder Hybrid 2WD & $2014-2015$ & 0.7 & Hitachi & Mild \\
\hline Nissan & Rogue Hybrid & $2017-2019$ & 0.7 & Hitachi & Full \\
\hline Ram & 1500 & $2019-2021$ & 0.4 & LG Chem & Mild \\
\hline Toyota & Avalon Hybrid & 2021 & 1.0 & Primearth EV Energy & Full \\
\hline Toyota & Camry Hybrid & $2018-2021$ & 1.0 & Primearth EV Energy & Full \\
\hline Toyota & Corolla Hybrid & 2021 & 0.7 & Primearth EV Energy & Full \\
\hline Toyota & Prius & $2017-2021$ & 0.7 & Toyota/Panasonic & Full \\
\hline Toyota & RAV4 Hybrid & 2021 & 0.9 & Primearth EV Energy & Full \\
\hline Toyota & Sienna & 2021 & 1.9 & Primearth EV Energy & Full \\
\hline Toyota & Venza & 2021 & 0.9 & Primearth EV Energy & Full \\
\hline Volkswagen & Jetta & $2013-2016$ & 1.1 & Sanyo & Full \\
\hline
\end{tabular}




\section{REFERENCES}

[47] https://insideevs.com/news/327379/starting-in-2018-audis-belgian-factory-will-only-produce-long-range-e-tron-suv-amp-battery-packs/, accessed 23 Dec 2020 .

[48] https://www.theverge.com/2019/4/19/18508066/audi-etron-delay-batteries-lg-chem, accessed 23 Dec 2020.

[49] https://www.businessinsider.com/audi-pauses-e-tron-suv-production-due-to-battery-shortage-2020-2, accessed 23 Dec 2020.

[50] https://www.theverge.com/2019/4/19/18508066/audi-etron-delay-batteries-lg-chem, accessed 23 Dec 2020.

[51] https://insideevs.com/news/327379/starting-in-2018-audis-belgian-factory-will-only-produce-long-range-e-tron-suv-amp-battery-packs, accessed 23 Dec 2020 .

[52] http://www.skc.co.kr/upload/ir/20191216/20191216134740943289.pdf, accessed 23 Dec 2020.

[53] https://www.audi-mediacenter.com/en/press-releases/start-of-production-of-the-audi-e-tron-10637, accessed 23 Dec 2020.

[54] https://www.electrive.com/2020/02/10/lack-of-batteries-hinders-mercedes-and-halts-i-pace-production-at-jagauar/, accessed 23 Dec 2020.

[55] https://insideevs.com/news/372099/audi-e-tron-produced-china-2020/, accessed 23 Dec 2020.

[56] https://www.greencarcongress.com/2011/09/sbl-20110913.html, accessed 23 Dec 2020.

[57] https://www.popsci.com/cars/article/2012-02/driven-all-electric-bmw-active-e/, accessed 23 Dec 2020.

[58] https://www.greencarcongress.com/2011/09/sbl-20110913.html, accessed 23 Dec 2020.

[59] https://insideevs.com/news/339449/watch-deutsche-accumotive-battery-production/, accessed 23 Dec 2020.

[60] https://www.autoblog.com/2011/07/18/video-bmw-kicks-off-production-of-the-active-e/, accessed 23 Dec 2020.

[61] https://theicct.org/sites/default/files/publications/EV_Government_WhitePaper_20180514.pdf, accessed 23 Dec 2020.

[62] https://www.greencarcongress.com/2011/09/sbl-20110913.html, accessed 23 Dec 2020.

[63] https://avt.inl.gov/sites/default/files/pdf/fsev/batteryi5486.pdf, accessed 23 Dec 2020.

[64] https://theicct.org/sites/default/files/publications/EV_Government_WhitePaper_20180514.pdf, accessed 23 Dec 2020.

[65] https://www.greencarcongress.com/2011/09/sbl-20110913.html, accessed 23 Dec 2020.

[66] https://www.greencarcongress.com/2020/02/20200207-dingolfing.html, accessed 23 Dec 2020.

[67] https://cleantechnica.com/2018/01/01/volkswagen-e-golf-production-capacity-double-next-year/, accessed 23 Dec 2020.

[68] https://www.press.bmwgroup.com/usa/article/detail/T0145870EN_US/a-new-era-dawns:-bmw-group-begins-series-production-of-the-bmw-i3-electric-carin-leipzig-/-industrial-scale-manufacture-of-cfrp-makes-its-debut-in-the-car-industry-/-commitment-to-a-sustainable-production-process?language=en_US, accessed 23 Dec 2020.

[69] https://www.electrive.com/2019/07/24/bmw-double-battery-production-capacity-in-spartanburg/, accessed 23 Dec 2020.

[70] https://cleantechnica.com/2018/01/01/volkswagen-e-golf-production-capacity-double-next-year/, accessed 23 Dec 2020.

[71] https://cleantechnica.com/2018/01/01/volkswagen-e-golf-production-capacity-double-next-year/, accessed 23 Dec 2020.

[72] https://www.samsungsdi.com/sdi-news/1642.html?idx=1642, accessed 23 Dec 2020.

[73] https://pushevs.com/2017/02/16/lg-chem-will-expand-battery-cell-production-usa-china/, accessed 23 Dec 2020.

[74] https://electricrevs.com/2019/04/30/lg-sues-sk-alleges-stolen-trade-secrets-used-to-make-kia-niro-and-future-vw-batteries/, accessed 23 Dec 2020.

[75] https://ngtnews.com/lg-chem-fiat-chrysler-sign-electric-vehicle-battery-deal, accessed 23 Dec 2020.

[76] https://theicct.org/sites/default/files/publications/EV_Government_WhitePaper_20180514.pdf, accessed 23 Dec 2020.

[77] https://www.usitc.gov/publications/332/journals/the_supply_chain_for_electric_vehicle_batteries.pdf, accessed 23 Dec 2020. 
[78] https://www.usitc.gov/publications/332/journals/the_supply_chain_for_electric_vehicle_batteries.pdf, accessed 23 Dec 2020.

[79] https://cleantechnica.com/2018/07/08/tesla-model-3-chevy-bolt-battery-packs-examined/, accessed 23 Dec 2020.

[80] http://fortune.com/2017/07/17/gm-shutdown-chevy-bolt-supply/, accessed 23 Dec 2020.

[81] https://vpic.nhtsa.dot.gov/mid/home/displayfile/1fd5e03c-63b7-43eb-b323-1ea5f58ebaba, accessed 23 Dec 2020.

[82] https://electrek.co/2020/11/13/gm-recall-chevy-bolt-evs-potential-fire-risk/, accessed 23 Dec 2020.

[83] https://www.theverge.com/2020/11/13/21564217/gm-chevy-bolt-recall-battery-fire-lg-chem, accessed 23 Dec 2020.

[84] https://electricrevs.com/2019/04/30/lg-sues-sk-alleges-stolen-trade-secrets-used-to-make-kia-niro-and-future-vw-batteries/, accessed 23 Dec 2020.

[85] https://www.detroitnews.com/story/business/autos/general-motors/2020/02/19/gm-detroit-hamtramck-assembly-prepares-battery-poweredfuture/4694218002/, accessed 23 Dec 2020.

[86] https://insideevs.com/news/321593/gm-shifts-2015-chevy-spark-ev-battery-production-in-house-pushes-a123-out/, accessed 23 Dec 2020.

[87] https://www.greencarreports.com/news/1085827_battery-maker-lg-chem-biggest-electric-car-winner-of-all, accessed 23 Dec 2020.

[88] https://www.greencarcongress.com/2014/05/20140514-gm.html, accessed 23 Dec 2020.

[89] https://www.nytimes.com/2012/10/17/business/battery-maker-a123-systems-files-for-bankruptcy.html, accessed 23 Dec 2020.

[90] https://evobsession.com/chevy-spark-ev-now-being-manufactured-in-usa/, accessed 23 Dec 2020.

[91] https://www.greencarreports.com/news/1085622_2014-chevrolet-spark-ev-first-drive-report, accessed 23 Dec 2020.

[92] https://avt.inl.gov/sites/default/files/pdf/fsev/batterySpark4878.pdf, accessed 23 Dec 2020.

[93] https://avt.inl.gov/sites/default/files/pdf/fsev/batterySpark4878.pdf, accessed 23 Dec 2020.

[94] https://www.greencarreports.com/news/1085827_battery-maker-lg-chem-biggest-electric-car-winner-of-all, accessed 23 Dec 2020.

ฟ [95] https://www.greencarcongress.com/2014/05/20140514-gm.html, accessed 23 Dec 2020.

[96] https://vpic.nhtsa.dot.gov/mid/home/displayfile/1fd5e03c-63b7-43eb-b323-1ea5f58ebaba, accessed 23 Dec 2020.

[97] https://www.greencarcongress.com/2012/12/bosch-20121213.html, accessed 23 Dec 2020.

[98] https://electriccarsreport.com/2012/12/fiat-500e-is-the-first-ev-to-feature-bosch-battery-pack/, accessed 23 Dec 2020.

[99] https://chargedevs.com/features/a-reluctant-gem-the-fiat-500e-ev/, accessed 23 Dec 2020.

[100] https://ngtnews.com/lg-chem-fiat-chrysler-sign-electric-vehicle-battery-deal, accessed 23 Dec 2020.

[101] https://www.usitc.gov/publications/332/journals/the_supply_chain_for_electric_vehicle_batteries.pdf, accessed 23 Dec 2020.

[102] https://www.greencarcongress.com/2012/12/bosch-20121213.html, accessed 23 Dec 2020.

[103] https://www.usitc.gov/publications/332/journals/the_supply_chain_for_electric_vehicle_batteries.pdf, accessed 23 Dec 2020.

[104] http://www.adandp.media/articles/5-things-about-the-fiat-500e, accessed 23 Dec 2020.

[105] https://www.greencarcongress.com/2010/07/focus-cpi-20100713.html, accessed 23 Dec 2020.

[106] https://www.greencarcongress.com/2010/11/lgchem-20101107.html, accessed 23 Dec 2020.

[107] https://avt.inl.gov/sites/default/files/pdf/fsev/batteryFocus1700.pdf, accessed 23 Dec 2020.

[108] https://www.greencarcongress.com/2010/07/focus-cpi-20100713.html, accessed 23 Dec 2020.

[109] https://www.greencarcongress.com/2011/01/cmaxenergi-20110110.html, accessed 23 Dec 2020.

[110] https://social.ford.com/en_US/story/sustainability/electric-vehicle/ford-focus-electric-gets-powered-up.html, accessed 23 Dec 2020.

[111] https://www.usitc.gov/publications/332/journals/the_supply_chain_for_electric_vehicle_batteries.pdf, accessed 23 Dec 2020.

[112] https://pushevs.com/2017/02/16/lg-chem-will-expand-battery-cell-production-usa-china/, accessed 23 Dec 2020.

[113] https://ngtnews.com/lg-chem-fiat-chrysler-sign-electric-vehicle-battery-deal, accessed 23 Dec 2020.

[114] https://www.greencarcongress.com/2010/07/focus-cpi-20100713.html, accessed 23 Dec 2020.

[115] https://www.michiganradio.org/post/lg-chem-finally-begins-production-lithium-ion-batteries-holland, accessed 23 Dec 2020.

[116] https://www.usitc.gov/publications/332/journals/the_supply_chain_for_electric_vehicle_batteries.pdf, accessed 23 Dec 2020. 
[117] https://www.usitc.gov/publications/332/journals/the_supply_chain_for_electric_vehicle_batteries.pdf, accessed 23 Dec 2020.

[118] https://ngtnews.com/lg-chem-fiat-chrysler-sign-electric-vehicle-battery-deal, accessed 23 Dec 2020.

[119] https://media.ford.com/content/dam/fordmedia/North\%20America/US/product/2016/2016-ford-focus-electric-product-sheet.pdf, accessed 23 Dec 2020.

[120] https://fordauthority.com/2020/01/ford-mustang-mach-e-and-electric-transit-van-share-battery-packs/, accessed 23 Dec 2020.

[121] https://www.greencarreports.com/news/1126230_how-many-mustang-mach-e-electric-suvs-will-ford-build-we-ve-got-numbers, accessed 23 Dec 2020.

[122] https://fordauthority.com/2020/01/ford-mustang-mach-e-and-electric-transit-van-share-battery-packs/, accessed 23 Dec 2020.

[123] https://www.greencarreports.com/news/1126230_how-many-mustang-mach-e-electric-suvs-will-ford-build-we-ve-got-numbers, accessed 23 Dec 2020.

[124] https://www.freep.com/story/money/cars/ford/2020/06/01/ford-manufacturing-mexico-build-mustang-mach-e/5309113002/, accessed 23 Dec 2020.

[125] https://www.greencarcongress.com/2019/02/20190206-hondacatl.html, accessed 23 Dec 2020.

[126] https://www.greencarreports.com/news/1052740_toshiba-li-ion-batteries-to-appear-in-hondas-electric-car, accessed 23 Dec 2020.

[127] https://www.marklines.com/en/report_all/rep1217_201310\#report_area_6, accessed 23 Dec 2020.

[128] https://www.greencarcongress.com/2011/11/scib-20111117.html, accessed 23 Dec 2020.

[129] https://www.greencarcongress.com/2010/07/honda-20100720.html, accessed 23 Dec 2020.

[130] https://automobiles.honda.com/news/press-releases-article.aspx?Article=6741-en, accessed 23 Dec 2020.

[131] https://thedriven.io/2020/11/17/hyundai-turns-to-sk-innovation-batteries-instead-of-lg-chem-in-light-of-kona-ev-battery-fires/, accessed 23 Dec 2020.

[132] https://insideevs.com/news/328375/hyundai-ioniq-electric-has-a-28-kwh-battery-105-miles-real-range/, accessed 23 Dec 2020.

[133] https://insideevs.com/news/333540/lg-chem-cant-keep-up-with-unexpectedly-high-demand-for-hyundai-ioniq-electric/, accessed 23 Dec 2020.

[134] https://theicct.org/sites/default/files/publications/EV_Government_WhitePaper_20180514.pdf, accessed 23 Dec 2020.

Y [135] https://electrek.co/2017/06/09/hyundai-ioniq-electric-production-increase/, accessed 23 Dec 2020.

[136] https://www.electrive.com/2019/08/17/hyundai-launches-two-battery-electric-models-in-china/, accessed 23 Dec 2020.

[137] https://electricrevs.com/2019/04/30/lg-sues-sk-alleges-stolen-trade-secrets-used-to-make-kia-niro-and-future-vw-batteries/, accessed 23 Dec 2020.

[138] https://electricrevs.com/2019/04/30//g-sues-sk-alleges-stolen-trade-secrets-used-to-make-kia-niro-and-future-vw-batteries/, accessed 23 Dec 2020.

[139] https://www.electrive.com/2019/08/17/hyundai-launches-two-battery-electric-models-in-china/, accessed 23 Dec 2020.

[140] https://www.greencarcongress.com/2018/03/20180329-kona.html, accessed 23 Dec 2020.

[141] https://insideevs.com/pre-orders-open-hyundai-kona-ev-south-korea/, accessed 23 Dec 2020.

[142] https://www.electrive.com/2020/02/10/lack-of-batteries-hinders-mercedes-and-halts-i-pace-production-at-jagauar/, accessed 23 Dec 2020.

[143] https://qz.com/1447251/jaguars-full-response-to-questions-about-the-i-pace-electric-cars-battery/, accessed 23 Dec 2020.

[144] http://webcache.googleusercontent.com/search?q=cache:6ZfmFkXvwQMJ:https://qz.com/1446315/jaguar-i-pace-is-coming-for-tesla-with-a-battery-thatdoesnt-make-sense/\&hl=en\&gl=us\&strip=1\&vwsrc=0, accessed 23 Dec 2020.

[145] https://www.electrive.com/2020/02/10/lack-of-batteries-hinders-mercedes-and-halts-i-pace-production-at-jagauar/, accessed 23 Dec 2020.

[146] https://www.theverge.com/2020/2/11/21133010/jaguar-ipace-production-halt-lg-chem-batteries, accessed 23 Dec 2020.

[147] https://media.jaguar.com/node/16726, accessed 23 Dec 2020.

[148] https://electricrevs.com/2019/04/30//g-sues-sk-alleges-stolen-trade-secrets-used-to-make-kia-niro-and-future-vw-batteries/, accessed 23 Dec 2020.

[149] http://www.skc.co.kr/upload/ir/20191216/20191216134740943289.pdf, accessed 23 Dec 2020.

[150] https://electricrevs.com/2019/04/30/lg-sues-sk-alleges-stolen-trade-secrets-used-to-make-kia-niro-and-future-vw-batteries/, accessed 23 Dec 2020.

[151] https://www.greencarreports.com/news/1129543_hyundai-sk-innovation-leased-ev-battery-packs-sustainable-ecosystem, accessed 23 Dec 2020.

[152] http://pr.kia.com/en/now/tour/global-plant/hwaseong-plant.do, accessed 23 Dec 2020.

[153] https://electrek.co/2017/03/06/sk-innovation-expanding-battery/, accessed 23 Dec 2020.

[154] https://www.usitc.gov/publications/332/journals/the_supply_chain_for_electric_vehicle_batteries.pdf, accessed 23 Dec 2020.

[155] https://avt.inl.gov/sites/default/files/pdf/fsev/batterySoul1908.pdf, accessed 23 Dec 2020. 
[156] https://www.koreatimes.co.kr/www/news/biz/2015/07/123_183736.html, accessed 23 Dec 2020.

[157] https://electrek.co/2017/03/06/sk-innovation-expanding-battery/, accessed 23 Dec 2020.

[158] https://www.usitc.gov/publications/332/journals/the_supply_chain_for_electric_vehicle_batteries.pdf, accessed 23 Dec 2020.

[159] https://www.usitc.gov/publications/332/journals/the_supply_chain_for_electric_vehicle_batteries.pdf, accessed 23 Dec 2020.

[160] https://insideevs.com/news/320956/production-of-kia-soul-ev-to-begin-in-april-sales-to-follow-immediately-in-south-korea/, accessed 23 Dec 2020.

[161] https://electrek.co/2016/02/18/mercedes-select-a-li-ion-battery-cell-supplier-for-its-upcoming-line-of-electric-vehicles/, accessed 23 Dec 2020.

[162] https://www.greencarreports.com/news/1102752_daimler-to-spend-500-million-on-electric-car-battery-factory, accessed 23 Dec 2020.

[163] https://avt.inl.gov/sites/default/files/pdf/fsev/batteryBClass4477.pdf, accessed 23 Dec 2020.

[164] https://www.greencarreports.com/news/1102752_daimler-to-spend-500-million-on-electric-car-battery-factory, accessed 23 Dec 2020.

[165] http://www.myautoworld.com/mercedes/mercedes-plants/mercedes-plants.html, accessed 23 Dec 2020.

[166] https://de.reuters.com/article/sk-innovation-daimler-idUKL3N15W1A1, accessed 23 Dec 2020.

[167] https://electrek.co/2016/02/18/mercedes-select-a-li-ion-battery-cell-supplier-for-its-upcoming-line-of-electric-vehicles/, accessed 23 Dec 2020.

[168] https://www.greencarreports.com/news/1102752_daimler-to-spend-500-million-on-electric-car-battery-factory, accessed 23 Dec 2020.

[169] https://pushevs.com/2016/02/18/sk-innovation-will-supply-battery-cells-for-mercedes-benz/, accessed 23 Dec 2020.

[170] https://www.greencarreports.com/news/1102752_daimler-to-spend-500-million-on-electric-car-battery-factory, accessed 23 Dec 2020.

[171] https://www.greencarcongress.com/2016/10/20161026-mini.html, accessed 23 Dec 2020.

[172] https://www.electrive.com/2020/03/11/mini-cooper-se-us-market-launch-complete/, accessed 23 Dec 2020.

[173] https://www.autoblog.com/2007/05/08/mitsubishi-forms-jv-with-gs-yuasa-to-build-lithium-ion-batteries/, accessed 23 Dec 2020.

[174] https://avt.inl.gov/sites/default/files/pdf/fsev/batteryiMiev3178.pdf, accessed 23 Dec 2020.

[175] https://chargedevs.com/newswire/mitsubishi-pauses-production-of-two-plug-in-models-after-battery-pack-fires/, accessed 23 Dec 2020

[176] https://vpic.nhtsa.dot.gov/mid/home/displayfile/9862867c-d0b1-4356-a98f-2e3537c07bc7, accessed 23 Dec 2020.

[177] https://vpic.nhtsa.dot.gov/mid/home/displayfile/bfc03c8f-f5a3-449e-8d7a-4f8d105c5a68, accessed 23 Dec 2020.

[178] https://avt.inl.gov/sites/default/files/pdf/fsev/batteryrpt2011NissanLeaf0356.pdf, accessed 23 Dec 2020.

[179] https://thenewswheel.com/nissan-leaf-history/, accessed 23 Dec 2020.

[180] https://www.greencarreports.com/news/1084162_how-are-electric-car-batteries-made-photos-from-nissans-new-plant, accessed 23 Dec 2020.

[181] https://electrek.co/2018/08/03/nissan-sells-battery-cell-manufacturing-division/, accessed 23 Dec 2020.

[182] https://www.usitc.gov/publications/332/journals/the_supply_chain_for_electric_vehicle_batteries.pdf, accessed 23 Dec 2020

[183] https://avt.inl.gov/sites/default/files/pdf/fsev/batteryLeaf0646.pdf, accessed 23 Dec 2020.

[184] https://www.greencarreports.com/news/1084162_how-are-electric-car-batteries-made-photos-from-nissans-new-plant, accessed 23 Dec 2020.

[185] https://www.usitc.gov/publications/332/journals/the_supply_chain_for_electric_vehicle_batteries.pdf, accessed 23 Dec 2020.

[186] https://www.youtube.com/watch?v=Mun1Mct6JEs, accessed 23 Dec 2020.

[187] https://www.usitc.gov/publications/332/journals/the_supply_chain_for_electric_vehicle_batteries.pdf, accessed 23 Dec 2020.

[188] https://www.slashgear.com/nissan-leaf-production-to-kick-off-at-new-smyrna-tn-factory-in-late-2012-14165078/, accessed 23 Dec 2020.

[189] https://thenewswheel.com/nissan-leaf-history/, accessed 23 Dec 2020.

[190] https://www.polestar.com/global/press/press-release/polestar-confirms-battery-suppliers-for-its-electric-performance-cars, accessed 23 Dec 2020.

[191] https://www.polestar.com/global/press/press-release/polestar-confirms-battery-suppliers-for-its-electric-performance-cars, accessed 23 Dec 2020.

[192] https://insideevs.com/news/440321/luqiao-factory-polestar-2/, accessed 23 Dec 2020.

[193] https://www.autoweek.com/news/green-cars/a1709656/2020-porsche-taycan-will-be-priced-between-cayman-and-panamera/, accessed 23 Dec 2020.

[194] https://www.autoweek.com/news/green-cars/a1709656/2020-porsche-taycan-will-be-priced-between-cayman-and-panamera/, accessed 23 Dec 2020.

[195] https://www.electrive.com/2019/05/18/draxlmaier-launches-construction-of-taycan-batteries/, accessed 23 Dec 2020. 
[196] https://www.autoweek.com/news/green-cars/a1709656/2020-porsche-taycan-will-be-priced-between-cayman-and-panamera/, accessed 23 Dec 2020. [197] https://www.autoweek.com/news/green-cars/a1709656/2020-porsche-taycan-will-be-priced-between-cayman-and-panamera/, accessed 23 Dec 2020. [198] https://newsroom.porsche.com/en/2019/company/porsche-taycan-factory-zuffenhausen-production-review-construction-18603.html, accessed 23 Dec 2020.

[199] https://www.greencarcongress.com/2014/11/20141116.html, accessed 23 Dec 2020.

[200] https://avt.inl.gov/sites/default/files/pdf/fsev/batteryElectric2457.pdf, accessed 23 Dec 2020.

[201] https://www.greencarcongress.com/2014/11/20141116.html, accessed 23 Dec 2020.

[202] https://www.greencarcongress.com/2020/05/20200527-kamenz.html, accessed 23 Dec 2020.

[203] https://insideevs.com/news/326146/lg-chem-confirmed-as-li-ion-battery-supplier-for-new-smart-ev/, accessed 23 Dec 2020.

[204] https://insideevs.com/news/339449/watch-deutsche-accumotive-battery-production/, accessed 23 Dec 2020.

[205] https://insideevs.com/news/339449/watch-deutsche-accumotive-battery-production/, accessed 23 Dec 2020.

[206] https://insideevs.com/news/339449/watch-deutsche-accumotive-battery-production/, accessed 23 Dec 2020.

[207] www.carsdirect.com/car-buying/where-are-smart-cars-built, accessed 23 Dec 2020.

[208] https://www.usitc.gov/publications/332/journals/the_supply_chain_for_electric_vehicle_batteries.pdf, accessed 23 Dec 2020. [209] https://www.greencarcongress.com/2017/01/20170105-tesla.html, accessed 23 Dec 2020.

[210] https://www.usitc.gov/publications/332/journals/the_supply_chain_for_electric_vehicle_batteries.pdf, accessed 23 Dec 2020. [211] https://www.usitc.gov/publications/332/journals/the_supply_chain_for_electric_vehicle_batteries.pdf, accessed 23 Dec 2020. [212] https://www.theverge.com/2020/9/22/21449238/tesla-electric-car-battery-tabless-cells-day-elon-musk, accessed 23 Dec 2020.

[213] https://www.tesla.com/gigafactory, accessed 23 Dec 2020.

[214] https://www.tesla.com/factory, accessed 23 Dec 2020.

[215] https://electrek.co/2018/12/29/tesla-model-3-assembly-video/, accessed 23 Dec 2020.

[216] https://www.hybridcars.com/confirmed-tesla-and-panasonic-to-build-gigafactory/, accessed 23 Dec 2020.

[217] https://electrek.co/2020/02/11/tesla-building-pilot-battery-cell-manufacturing-line-fremont/, accessed 23 Dec 2020.

[218] https://avt.inl.gov/sites/default/files/pdf/fsev/fact2014teslamodels.pdf, accessed 23 Dec 2020.

[219] https://theicct.org/sites/default/files/publications/EV_Government_WhitePaper_20180514.pdf, accessed 23 Dec 2020.

[220] https://electrek.co/2020/02/11/tesla-building-pilot-battery-cell-manufacturing-line-fremont/, accessed 23 Dec 2020.

[221] https://www.usitc.gov/publications/332/journals/the_supply_chain_for_electric_vehicle_batteries.pdf, accessed 23 Dec 2020.

[222] https://www.tesla.com/factory, accessed 23 Dec 2020.

[223] https://electrek.co/2020/02/11/tesla-building-pilot-battery-cell-manufacturing-line-fremont/, accessed 23 Dec 2020.

[224] https://insideevs.com/news/433334/sk-innovation-construction-2nd-us-battery-plant/, accessed 23 Dec 2020.

[225] https://www.usitc.gov/publications/332/journals/the_supply_chain_for_electric_vehicle_batteries.pdf, accessed 23 Dec 2020.

[226] https://theicct.org/sites/default/files/publications/EV_Government_WhitePaper_20180514.pdf, accessed 23 Dec 2020.

[227] https://electrek.co/2020/02/11/tesla-building-pilot-battery-cell-manufacturing-line-fremont/, accessed 23 Dec 2020.

[228] https://www.usitc.gov/publications/332/journals/the_supply_chain_for_electric_vehicle_batteries.pdf, accessed 23 Dec 2020.

[229] https://www.tesla.com/factory, accessed 23 Dec 2020.

[230] https://www.theverge.com/2020/9/22/21449238/tesla-electric-car-battery-tabless-cells-day-elon-musk, accessed 23 Dec 2020.

[231] https://www.theverge.com/2020/9/22/21449238/tesla-electric-car-battery-tabless-cells-day-elon-musk, accessed 23 Dec 2020.

[232] https://www.teslarati.com/tesla-model-y-production-date-summer-2020/, accessed 23 Dec 2020.

[233] https://www.cnbc.com/2019/05/29/tesla-fremont-factory-prepping-for-model-y-production-model-s-refresh.html, accessed 23 Dec 2020.

[234] https://www.toyota.com/content/vehicle-landing/2013/rav4ev/custom/rav4ev-quiz/RAV4-EV-CDF.pdf, accessed 23 Dec 2020. 
[235] https://www.greencarcongress.com/2010/11/rav4ev-20101117.html, accessed 23 Dec 2020.

[236] https://www.greencarcongress.com/2011/08/rav4ev-20110805.html, accessed 23 Dec 2020.

[237] http://toyota.custhelp.com/app/answers/detail/a_id/7660/ /where-are-toyota-vehicles-assembled-for-the-u.s.-market\%3F, accessed 23 Dec 2020.

[238] https://pushevs.com/2017/01/09/volkswagen-replaces-battery-cell-supplier/, accessed 23 Dec 2020.

[239] https://avt.inl.gov/sites/default/files/pdf/fsev/batteryEGolf2012.pdf, accessed 23 Dec 2020.

[240] https://www.greencarcongress.com/2013/11/20131114-egolf.html, accessed 23 Dec 2020.

[241] https://chargedevs.com/features/the-2015-vw-e-golf-ushers-in-an-era-of-interchangeable-drivetrains-for-every-volkswagen-model/, accessed 23 Dec 2020.

[242] https://www.usitc.gov/publications/332/journals/the_supply_chain_for_electric_vehicle_batteries.pdf, accessed 23 Dec 2020.

[243] https://pushevs.com/2017/01/09/volkswagen-replaces-battery-cell-supplier/, accessed 23 Dec 2020.

[244] https://pushevs.com/2017/01/09/volkswagen-replaces-battery-cell-supplier/, accessed 23 Dec 2020.

[245] https://www.usitc.gov/publications/332/journals/the_supply_chain_for_electric_vehicle_batteries.pdf, accessed 23 Dec 2020.

[246] https://www.usitc.gov/publications/332/journals/the_supply_chain_for_electric_vehicle_batteries.pdf, accessed 23 Dec 2020.

[247] https://cleantechnica.com/2018/01/01/volkswagen-e-golf-production-capacity-double-next-year/, accessed 23 Dec 2020.

[248] https://www.nhtsa.gov/part-583-american-automobile-labeling-act-reports, accessed 23 Dec 2020.

[249] https://www.theverge.com/2020/11/13/21564217/gm-chevy-bolt-recall-battery-fire-lg-chem, accessed 23 Dec 2020.

[250] https://electrek.co/2020/11/13/gm-recall-chevy-bolt-evs-potential-fire-risk/, accessed 23 Dec 2020.

[251] https://www.reuters.com/article/idUSKBN2AO0JS, accessed 23 Dec 2020.

[252] https://electrek.co/2021/02/24/hyundai-announces-kona-ioniq-and-bus-battery-replacements/, accessed 23 Dec 2020.

[253] https://insideevs.com/news/328204/audi-a3-e-tron-detailed-specs/, accessed 23 Dec 2020.

[254] http://www.skc.co.kr/upload/ir/20191216/20191216134740943289.pdf, accessed 23 Dec 2020.

[255] http://www.skc.co.kr/upload/ir/20191216/20191216134740943289.pdf, accessed 23 Dec 2020.

[256] http://fourtitude.com/news/Audi_News_1/first-audi-a3-e-tron-drives-assembly-line/, accessed 23 Dec 2020.

[257] https://www.businessinsider.com/audi-pauses-e-tron-suv-production-due-to-battery-shortage-2020-

2\#: :text=But\%20the\%20e\%2DTron\%2C\%20Audi\%27s,e\%2DTron\%20production\%20last\%20year, accessed 23 Dec 2020.

[258] https://insideevs.com/news/327379/starting-in-2018-audis-belgian-factory-will-only-produce-long-range-e-tron-suv-amp-battery-packs/, accessed 23 Dec 2020 .

[259] https://www.audi-mediacenter.com/en/neckarsulm-199, accessed 23 Dec 2020.

[260] https://www.theverge.com/2019/4/19/18508066/audi-etron-delay-batteries-lg-chem, accessed 23 Dec 2020.

[261] http://www.skc.co.kr/upload/ir/20191216/20191216134740943289.pdf, accessed 23 Dec 2020.

[262] https://insideevs.com/news/327379/starting-in-2018-audis-belgian-factory-will-only-produce-long-range-e-tron-suv-amp-battery-packs/, accessed 23 Dec 2020 .

[263] https://www.audi-mediacenter.com/en/press-releases/road-map-e-audi-in-the-era-of-electric-mobility-12146, accessed 23 Dec 2020.

[264] http://www.theinvestor.co.kr/view.php?ud=20180702000649, accessed 23 Dec 2020.

[265] https://theicct.org/sites/default/files/publications/EV_Government_WhitePaper_20180514.pdf, accessed 23 Dec 2020.

[266] https://cleantechnica.com/2018/01/01/volkswagen-e-golf-production-capacity-double-next-year/, accessed 23 Dec 2020.

[267] http://www.bmwgroup-plants.com/en/munich/products.html, accessed 23 Dec 2020.

[268] https://www.electrive.com/2019/08/02/bmw-530e-receives-battery-update/, accessed 23 Dec 2020.

[269] https://www.electrive.com/2019/08/02/bmw-530e-receives-battery-update/, accessed 23 Dec 2020.

[270] https://www.electrive.com/2019/08/02/bmw-530e-receives-battery-update/, accessed 23 Dec 2020.

[271] https://www.greencarcongress.com/2020/02/20200207-dingolfing.html, accessed 23 Dec 2020. 
[272] https://www.magna.com/company/newsroom/releases/release/2017/06/19/news-release---magna-to-produce-bmw-5-series-plug-in-hybrid, accessed 23 Dec 2020 .

[273] https://www.electrive.com/2019/07/24/bmw-double-battery-production-capacity-in-spartanburg/, accessed 23 Dec 2020.

[274] http://www.theinvestor.co.kr/view.php?ud=20180702000649, accessed 23 Dec 2020.

[275] http://www.theinvestor.co.kr/view.php?ud=20180702000649, accessed 23 Dec 2020.

[276] https://www.motor1.com/news/309024/bmw-7-series-facelift-production/, accessed 23 Dec 2020.

[277] http://www.compositesworld.com/articles/bmw-7-series-plant-dingolfing-germany, accessed 23 Dec 2020.

[278] https://www.electrive.com/2019/07/24/bmw-double-battery-production-capacity-in-spartanburg/, accessed 23 Dec 2020.

[279] http://www.theinvestor.co.kr/view.php?ud=20180702000649, accessed 23 Dec 2020.

[280] https://www.bmwblog.com/2016/08/01/bmw-edrive-motors-battery-pack-production-explained/, accessed 23 Dec 2020.

[281] http://www.greencarreports.com/news/1095619_strong-demand-for-bmw-i8-plug-in-hybrid-coupe-may-presage-production-rise, accessed 23 Dec 2020.

[282] https://www.electrive.com/2019/07/24/bmw-double-battery-production-capacity-in-spartanburg/, accessed 23 Dec 2020.

[283] https://www.greencarcongress.com/2019/07/20190724-bmwbattery.html, accessed 23 Dec 2020.

[284] https://www.electrive.com/2019/07/24/bmw-double-battery-production-capacity-in-spartanburg/, accessed 23 Dec 2020.

[285] https://www.electrive.com/2019/07/24/bmw-double-battery-production-capacity-in-spartanburg/, accessed 23 Dec 2020.

[286] https://insideevs.com/news/361812/bmw-us-doubles-battery-production-capacity/, accessed 23 Dec 2020.

[287] https://www.electrive.com/2019/07/24/bmw-double-battery-production-capacity-in-spartanburg/, accessed 23 Dec 2020.

[288] https://www.press.bmwgroup.com/usa/article/detail/T0299183EN_US/bmw-group-plant-spartanburg-more-than-doubles-capacity-for-battery-assembly-

2020-bmw-x5-xdrive45e-plug-in-hybrid-electric-vehicle-begins-production-in-spartanburg-sc-on-august-1?language=en_US, accessed 23 Dec 2020.

[289] https://www.electrive.com/2019/07/24/bmw-double-battery-production-capacity-in-spartanburg/, accessed 23 Dec 2020.

[290] https://www.press.bmwgroup.com/global/article/detail/T0310907EN/raw-material-supplies-for-battery-cells:-bmw-group-sources-sustainable-cobaltworth-around-100-million-euros-from-morocco?language=en, accessed 23 Dec 2020.

[291] https://www.greencarcongress.com/2019/07/20190724-bmwbattery.html, accessed 23 Dec 2020.

[292] https://www.electrive.com/2019/07/24/bmw-double-battery-production-capacity-in-spartanburg/, accessed 23 Dec 2020.

[293] https://www.electrive.com/2019/07/24/bmw-double-battery-production-capacity-in-spartanburg/, accessed 23 Dec 2020.

[294] https://www.greencarcongress.com/2019/07/20190724-bmwbattery.html, accessed 23 Dec 2020.

[295] https://www.electrive.com/2019/07/24/bmw-double-battery-production-capacity-in-spartanburg/, accessed 23 Dec 2020.

[296] https://www.bmwblog.com/2017/08/07/bmw-wants-modular-assembly-lines-keep-ice-phev-production-going/, accessed 23 Dec 2020.

[297] https://insideevs.com/news/325838/world-debut-bmw-x5-xdrive40e-plug-in-hybrid/, accessed 23 Dec 2020.

[298] https://investor.gm.com/news-releases/news-release-details/detroit-hamtramck-be-gms-first-assembly-plant-100-percent, accessed 23 Dec 2020.

[299] https://investor.gm.com/news-releases/news-release-details/detroit-hamtramck-be-gms-first-assembly-plant-100-percent, accessed 23 Dec 2020.

[300] https://media.cadillac.com/media/us/en/cadillac/vehicles/ct6-plugin/2017.html, accessed 23 Dec 2020.

[301] https://www.youtube.com/watch?v=2Ltptk3t6PA, accessed 23 Dec 2020.

[302] https://www.detroitnews.com/story/business/autos/general-motors/2016/01/14/gm-import-cadillac-ct-sedan-china/78808764/, accessed 23 Dec 2020.

[303] https://www.greencarreports.com/news/1083668_u-s--built-electric-cars-to-get-u-s--made-battery-cells-too, accessed 23 Dec 2020.

[304] https://web.archive.org/web/20170923182829/http://www.lgesspartner.com/au/front/introduction/introductionAbout.dev, accessed 23 Dec 2020.

[305] https://www.greencarreports.com/news/1083668_u-s--built-electric-cars-to-get-u-s--made-battery-cells-too, accessed 23 Dec 2020.

[306] https://www.greencarcongress.com/2014/05/20140514-gm.html, accessed 23 Dec 2020.

[307] https://media.gm.com/media/us/en/gm/autoshows/detroit.detail.html/content/Pages/news/us/en/2013/Aug/0802-ultrasonic-welding.html, accessed 23 Dec 2020 . 
[308] http://www.automoblog.net/2012/10/18/gm-unveils-production-location-of-cadillac-elr/, accessed 23 Dec 2020.

[309] https://www.greencarcongress.com/2010/11/lgchem-20101107.html, accessed 23 Dec 2020.

[310] https://avt.inl.gov/sites/default/files/pdf/phev/battery2011volt0815.pdf, accessed 23 Dec 2020.

[311] https://www.greencarreports.com/news/1086025_chevy-volt-plug-in-electric-cars-now-have-battery-cells-made-in-u-s, accessed 23 Dec 2020.

[312] https://www.greencarreports.com/news/1041341_2011-chevrolet-volt-lithium-ion-battery-pack-goes-into-production, accessed 23 Dec 2020.

[313] https://pushevs.com/2017/02/16/lg-chem-will-expand-battery-cell-production-usa-china/, accessed 23 Dec 2020.

[314] https://avt.inl.gov/sites/default/files/pdf/phev/batteryVolt1078.pdf, accessed 23 Dec 2020.

[315] https://avt.inl.gov/sites/default/files/pdf/phev/batteryVolt1377.pdf, accessed 23 Dec 2020.

[316] https://www.greencarreports.com/news/1086025_chevy-volt-plug-in-electric-cars-now-have-battery-cells-made-in-u-s, accessed 23 Dec 2020.

[317] https://pushevs.com/2017/02/16/lg-chem-will-expand-battery-cell-production-usa-china/, accessed 23 Dec 2020.

[318] https://ngtnews.com/lg-chem-fiat-chrysler-sign-electric-vehicle-battery-deal, accessed 23 Dec 2020.

[319] https://media.gm.com/media/us/en/gm/news.detail.html/content/Pages/news/us/en/2015/Jan/naias/chevrolet/volt/0112-volt-2016-intro.html, accessed 23 Dec 2020.

[320] https://vpic.nhtsa.dot.gov/mid/home/displayfile/1fd5e03c-63b7-43eb-b323-1ea5f58ebaba, accessed 23 Dec 2020.

[321] https://www.businesswire.com/news/home/20160222006619/en/LG-Chem-Battery-Pack-Technology-Power-All-New, accessed 23 Dec 2020.

[322] https://ngtnews.com/lg-chem-fiat-chrysler-sign-electric-vehicle-battery-deal, accessed 23 Dec 2020.

[323] https://www.businesswire.com/news/home/20160222006619/en/LG-Chem-Battery-Pack-Technology-Power-All-New, accessed 23 Dec 2020.

[324] https://www.businesswire.com/news/home/20160222006619/en/LG-Chem-Battery-Pack-Technology-Power-All-New, accessed 23 Dec 2020.

[325] https://ngtnews.com/lg-chem-fiat-chrysler-sign-electric-vehicle-battery-deal, accessed 23 Dec 2020.

[326] http://insideevs.com/chrysler-pacifica-hybrid-on-the-production-line-soon-at-a-dealer-near-you-video/, accessed 23 Dec 2020.

[327] https://www.greencarcongress.com/2012/02/panasonic-20120224.html, accessed 23 Dec 2020.

[328] https://www.energy.gov/sites/prod/files/2015/02/f19/batteryC-Max3813.pdf, accessed 23 Dec 2020.

[329] https://www.greencarcongress.com/2011/01/cmaxenergi-20110110.html, accessed 23 Dec 2020.

[330] https://www.forbes.com/sites/samabuelsamid/2019/08/22/2020-aviator-grand-touring-the-new-hot-rod-lincoln/?sh=2bae3aee6990, accessed 23 Dec 2020.

[331] http://www.autonews.com/article/20171118/RETAIL01/171129977/-1, accessed 23 Dec 2020.

[332] https://www.greencarcongress.com/2012/02/panasonic-20120224.html, accessed 23 Dec 2020.

[333] https://news.panasonic.com/global/press/data/en120224-10/en120224-10.html, accessed 23 Dec 2020.

[334] https://avt.inl.gov/sites/default/files/pdf/phev/batteryFusion1518.pdf, accessed 23 Dec 2020.

[335] https://www.forbes.com/sites/samabuelsamid/2019/08/22/2020-aviator-grand-touring-the-new-hot-rod-lincoln/?sh=2bae3aee6990, accessed 23 Dec 2020

[336] http://www.toledoblade.com/Automotive/2013/08/30/Ford-buildinga-best-sellerin-Flat-Rock-1.html, accessed 23 Dec 2020.

[337] http://www.hybridcars.com/2015-ford-fusion-energi-review/, accessed 23 Dec 2020.

[338] https://www.gs-yuasa.com/en/newsrelease/article.php?ucode=gs160711142215_271, accessed 23 Dec 2020.

[339] https://www.blue-energy.co.jp/en/newsrelease/pdf/20130711e.pdf, accessed 23 Dec 2020.

[340] https://www.blue-energy.co.jp/en/newsrelease/pdf/20130711e.pdf, accessed 23 Dec 2020.

[341] https://www.greencarreports.com/news/1097769_honda-accord-hybrid-production-relocates-from-ohio-to-japan, accessed 23 Dec 2020.

[342] https://www.greencarcongress.com/2020/01/20200127-clarity.html, accessed 23 Dec 2020.

[343] https://www.greencarcongress.com/2019/02/20190206-hondacatl.html, accessed 23 Dec 2020.

[344] https://hondanews.com/en-US/releases/2018-honda-clarity-plug-in-hybrid-press-kit, accessed 23 Dec 2020.

[345] https://thedriven.io/2020/11/17/hyundai-turns-to-sk-innovation-batteries-instead-of-lg-chem-in-light-of-kona-ev-battery-fires/, accessed 23 Dec 2020.

[346] https://theicct.org/sites/default/files/publications/EV_Government_WhitePaper_20180514.pdf, accessed 23 Dec 2020. 
[347] https://insideevs.com/news/333540/lg-chem-cant-keep-up-with-unexpectedly-high-demand-for-hyundai-ioniq-electric/, accessed 23 Dec 2020.

[348] https://www.greencarcongress.com/2015/05/20150526-sonata.html, accessed 23 Dec 2020.

[349] https://www.energy.gov/sites/prod/files/2014/03/f13/es002_alamgir_2013_p.pdf, accessed 23 Dec 2020.

[350] https://web.archive.org/web/20170923182829/http://www.lgesspartner.com/au/front/introduction/introductionAbout.dev, accessed 23 Dec 2020.

[351] http://www.skc.co.kr/upload/ir/20191216/20191216134740943289.pdf, accessed 23 Dec 2020.

[352] http://www.greencarcongress.com/2015/05/20150526-sonata.html, accessed 23 Dec 2020.

[353] https://www.assemblymag.com/articles/96052-fca-begins-assembling-plug-in-hybrid-jeep, accessed 23 Dec 2020.

[354] https://electrek.co/2017/03/06/sk-innovation-expanding-battery/, accessed 23 Dec 2020.

[355] https://electricrevs.com/2019/04/30/lg-sues-sk-alleges-stolen-trade-secrets-used-to-make-kia-niro-and-future-vw-batteries/, accessed 23 Dec 2020.

[356] https://electrek.co/2017/03/06/sk-innovation-expanding-battery/, accessed 23 Dec 2020.

[357] https://vpic.nhtsa.dot.gov/mid/home/displayfile/1b417ad6-d095-46e1-9ce2-a7adc44365d8, accessed 23 Dec 2020.

[358] http://www.skc.co.kr/upload/ir/20191216/20191216134740943289.pdf, accessed 23 Dec 2020.

[359] http://www.skc.co.kr/upload/ir/20191216/20191216134740943289.pdf, accessed 23 Dec 2020

[360] https://vpic.nhtsa.dot.gov/mid/home/displayfile/93893e76-d1c6-4678-aef7-a984c4acc12f, accessed 23 Dec 2020.

[361] http://ajudaily.com/view/20180411085704838, accessed 23 Dec 2020.

[362] http://www.koreatimes.co.kr/www/tech/2018/09/133_255094.html, accessed 23 Dec 2020.

[363] http://www.koreatimes.co.kr/www/tech/2018/09/133_255094.html, accessed 23 Dec 2020.

[364] http://www.koreatimes.co.kr/www/tech/2018/09/133_255094.html, accessed 23 Dec 2020

[365] https://teamtalk.jaguarlandrover.com/news/uk-to-become-ev-battery-production-powerhouse-thanks-to-faraday-challenge-initiative, accessed 23 Dec 2020.

[366] https://www.electrive.com/2019/07/05/jaguar-plans-to-build-bevs-at-castle-bromwich/, accessed 23 Dec 2020.

[367] https://www.forbes.com/sites/samabuelsamid/2019/08/22/2020-aviator-grand-touring-the-new-hot-rod-lincoln/?sh=1bdf5b046990, accessed 23 Dec 2020.

[368] https://www.forbes.com/sites/samabuelsamid/2019/08/22/2020-aviator-grand-touring-the-new-hot-rod-lincoln/?sh=1bdf5b046990, accessed 23 Dec 2020.

[369] https://www.motortrend.com/news/2020-lincoln-aviator-first-look-review/, accessed 23 Dec 2020.

[370] https://media.ford.com/content/fordmedia/fna/us/en/news/2019/06/24/ford-chicago-plants-transformed-new-vehicle-production-begins.html, accessed 23 Dec 2020.

[371] https://evobsession.com/sk-innovation-chosen-as-lithium-ion-ev-battery-supplier-by-mercedes-benz/, accessed 23 Dec 2020.

[372] https://pushevs.com/2016/10/30/sk-innovation-to-quadruple-ev-battery-cell-production-in-2018/, accessed 23 Dec 2020.

[373] https://www.greencarcongress.com/2016/06/20160613-daimler3.html, accessed 23 Dec 2020.

[374] https://evobsession.com/sk-innovation-chosen-as-lithium-ion-ev-battery-supplier-by-mercedes-benz/, accessed 23 Dec 2020.

[375] https://highwaynewspro.com/car-reviews/mercedes-benz-shows-its-battery-pack-plant-in-kamenz-video-2/, accessed 23 Dec 2020.

[376] https://www.greencarreports.com/news/1128376_mercedes-benz-details-how-it-will-ramp-up-battery-production-for-evs, accessed 23 Dec 2020.

[377] https://www.daimler.com/career/about-us/locations/location-detail-page-5244.html, accessed 23 Dec 2020.

[378] https://evobsession.com/sk-innovation-chosen-as-lithium-ion-ev-battery-supplier-by-mercedes-benz/, accessed 23 Dec 2020.

[379] https://pushevs.com/2016/10/30/sk-innovation-to-quadruple-ev-battery-cell-production-in-2018/, accessed 23 Dec 2020.

[380] https://www.greencarcongress.com/2016/06/20160613-daimler3.html, accessed 23 Dec 2020.

[381] https://evobsession.com/sk-innovation-chosen-as-lithium-ion-ev-battery-supplier-by-mercedes-benz/, accessed 23 Dec 2020.

[382] https://highwaynewspro.com/car-reviews/mercedes-benz-shows-its-battery-pack-plant-in-kamenz-video-2/, accessed 23 Dec 2020.

[383] https://www.greencarreports.com/news/1128376_mercedes-benz-details-how-it-will-ramp-up-battery-production-for-evs, accessed 23 Dec 2020.

[384] https://www.autoblog.com/2015/11/29/mercedes-glc-production-valmet-finland-official/, accessed 23 Dec 2020. 
[385] http://media.daimler.com/marsMediaSite/en/instance/ko/At-a-glance-Electric-initiative-at-Mercedes-Benz-Cars.xhtml?oid=32963028, accessed 23 Dec 2020.

[386] https://evobsession.com/sk-innovation-chosen-as-lithium-ion-ev-battery-supplier-by-mercedes-benz/, accessed 23 Dec 2020.

[387] https://pushevs.com/2016/10/30/sk-innovation-to-quadruple-ev-battery-cell-production-in-2018/, accessed 23 Dec 2020.

[388] https://www.greencarcongress.com/2016/06/20160613-daimler3.html, accessed 23 Dec 2020.

[389] https://evobsession.com/sk-innovation-chosen-as-lithium-ion-ev-battery-supplier-by-mercedes-benz/, accessed 23 Dec 2020.

[390] https://highwaynewspro.com/car-reviews/mercedes-benz-shows-its-battery-pack-plant-in-kamenz-video-2/, accessed 23 Dec 2020.

[391] https://www.greencarreports.com/news/1128376_mercedes-benz-details-how-it-will-ramp-up-battery-production-for-evs, accessed 23 Dec 2020.

[392] https://www.daimler.com/career/about-us/locations/location-detail-page-5244.html, accessed 23 Dec 2020.

[393] http://www.mykiasoulev.com/forum/viewtopic.php?t=326\&start=20, accessed 23 Dec 2020.

[394] https://evobsession.com/sk-innovation-chosen-as-lithium-ion-ev-battery-supplier-by-mercedes-benz/, accessed 23 Dec 2020.

[395] https://www.edaily.co.kr/news/read?newsId=03263606612814232\&mediaCodeNo=257, accessed 23 Dec 2020.

[396] http://www.mykiasoulev.com/forum/viewtopic.php?t=326\&start=20, accessed 23 Dec 2020.

[397] https://evobsession.com/sk-innovation-chosen-as-lithium-ion-ev-battery-supplier-by-mercedes-benz/, accessed 23 Dec 2020.

[398] http://www.myautoworld.com/mercedes/mercedes-plants/mercedes-plants.html, accessed 23 Dec 2020.

[399] https://www.vdlnedcar.nl/nl?news/2699772/VDL+Nedcar+gaat+de+nieuwe+MINI+Countryman+produceren.aspx\#.WmaBmcvvLqA, accessed 23 Dec 2020 .

[400] https://www.wardsauto.com/engines/ev-pioneer-mitsubishi-swept-currents-change, accessed 23 Dec 2020.

[401] https://www.myoutlanderphev.com/forum/viewtopic.php?f=10\&t=3480, accessed 23 Dec 2020.

[402] https://theicct.org/sites/default/files/publications/EV_Government_WhitePaper_20180514.pdf, accessed 23 Dec 2020.

[403] https://www.wardsauto.com/engines/ev-pioneer-mitsubishi-swept-currents-change, accessed 23 Dec 2020.

[404] https://www.mitsubishicars.com/rs/file/monroney?vin=JA4J24A56JZ029798, accessed 23 Dec 2020.

[405] https://arstechnica.com/cars/2019/11/the-polestar-1-is-a-turbocharged-supercharged-plug-in-hybrid-enigma/, accessed 23 Dec 2020.

[406] https://arstechnica.com/cars/2019/11/the-polestar-1-is-a-turbocharged-supercharged-plug-in-hybrid-enigma/, accessed 23 Dec 2020.

[407] https://www.polestar.com/global/press/press-release/first-polestar-1-prototype-cars-start-production, accessed 23 Dec 2020.

[408] https://pushevs.com/2016/06/25/bmw-i8-and-porsche-panamera-s-e-hybrid-will-be-upgraded-soon/, accessed 23 Dec 2020.

[409] https://www.porsche.com/usa/aboutporsche/pressreleases/pag/?pool=international-de\&id=320678, accessed 23 Dec 2020.

[410] https://newsroom.porsche.com/en/products/porsche-builds-the-600000th-cayenne-10748.html, accessed 23 Dec 2020.

[411] https://www.automobilemag.com/news/porsche-cayenne-turbo-review/, accessed 23 Dec 2020.

[412] https://pushevs.com/2016/06/25/bmw-i8-and-porsche-panamera-s-e-hybrid-will-be-upgraded-soon/, accessed 23 Dec 2020.

[413] https://www.porsche.com/usa/aboutporsche/pressreleases/pag/?pool=international-de\&id=320678, accessed 23 Dec 2020.

[414] http://europe.autonews.com/article/20130726/ANE/307269966/porsche-bullish-on-plug-in-panamera, accessed 23 Dec 2020.

[415] https://news.panasonic.com/global/press/data/en111129-2/en111129-2.html, accessed 23 Dec 2020.

[416] https://avt.inl.gov/sites/default/files/pdf/phev/batteryPrius6237.pdf, accessed 23 Dec 2020.

[417] https://news.panasonic.com/global/press/data/en111129-2/en111129-2.html, accessed 23 Dec 2020.

[418] http://toyota.custhelp.com/app/answers/detail/a_id/7660/ /where-are-toyota-vehicles-assembled-for-the-u.s.-market\%3F, accessed 23 Dec 2020.

[419] https://insideevs.com/news/342308/toyota-will-team-up-with-panasonic-on-high-capacity-ev-batteries/, accessed 23 Dec 2020.

[420] https://theicct.org/sites/default/files/publications/EV_Government_WhitePaper_20180514.pdf, accessed 23 Dec 2020.

[421] https://www.wardsauto.com/engines/primearth-says-toyota-eyes-us-battery-plant, accessed 23 Dec 2020.

[422] https://electrek.co/2020/06/30/toyota-cuts-output-of-rav4-prime-plug-in-hybrid-for-us/, accessed 23 Dec 2020. 
[423] https://www.electrive.com/2020/03/06/volvo-launches-battery-assembly-in-ghent/, accessed 23 Dec 2020.

[424] https://www.globalfleet.com/en/new-energies/europe/features/volvo-secures-battery-supply-catl-and-lg-chem, accessed 23 Dec 2020.

[425] http://www.skc.co.kr/upload/ir/20191216/20191216134740943289.pdf, accessed 23 Dec 2020.

[426] http://autoweek.com/article/car-news/chinese-built-volvo-s90-headed-our-way, accessed 23 Dec 2020.

[427] https://www.electrive.com/2020/03/06/volvo-launches-battery-assembly-in-ghent/, accessed 23 Dec 2020.

[428] https://www.globalfleet.com/en/new-energies/europe/features/volvo-secures-battery-supply-catl-and-lg-chem, accessed 23 Dec 2020.

[429] https://www.electrive.com/2020/03/06/volvo-launches-battery-assembly-in-ghent/, accessed 23 Dec 2020.

[430] https://www.electrive.com/2020/03/06/volvo-launches-battery-assembly-in-ghent/, accessed 23 Dec 2020.

[431] https://www.media.volvocars.com/global/en-gb/media/pressreleases/226641/volvo-cars-to-produce-lynk-and-co-cars-at-ghent-belgium-plant, accessed 23 Dec 2020.

[432] https://www.electrive.com/2020/03/06/volvo-launches-battery-assembly-in-ghent/, accessed 23 Dec 2020.

[433] https://www.energy.gov/sites/prod/files/2014/03/f13/es002_alamgir_2013_p.pdf, accessed 23 Dec 2020.

[434] https://www.globalfleet.com/en/new-energies/europe/features/volvo-secures-battery-supply-catl-and-lg-chem, accessed 23 Dec 2020.

[435] https://www.electrive.com/2020/03/06/volvo-launches-battery-assembly-in-ghent/, accessed 23 Dec 2020.

[436] https://www.globalfleet.com/en/new-energies/europe/features/volvo-secures-battery-supply-catl-and-lg-chem, accessed 23 Dec 2020.

[437] http://insideevs.com/plug-in-volvo-xc60-t8-enters-u-s-next-month-with-10-4-kwh-battery/, accessed 23 Dec 2020.

[438] https://www.electrive.com/2020/03/06/volvo-launches-battery-assembly-in-ghent/, accessed 23 Dec 2020.

[439] https://www.globalfleet.com/en/new-energies/europe/features/volvo-secures-battery-supply-catl-and-lg-chem, accessed 23 Dec 2020.

[440] https://web.archive.org/web/20170923182829/http://www.lgesspartner.com/au/front/introduction/introductionAbout.dev, accessed 23 Dec 2020.

[441] https://www.electrive.com/2020/03/06/volvo-launches-battery-assembly-in-ghent/, accessed 23 Dec 2020.

[442] https://www.globalfleet.com/en/new-energies/europe/features/volvo-secures-battery-supply-catl-and-lg-chem, accessed 23 Dec 2020.

[443] https://www.media.volvocars.com/global/en-gb/media/pressreleases/147889/end-of-an-era-as-swedish-production-of-volvo-xc90-stops-after-12-years, accessed 23 Dec 2020.

[444] https://www.nhtsa.gov/part-583-american-automobile-labeling-act-reports, accessed 23 Dec 2020.

[445] https://www.youtube.com/watch?v=6xIEkgyL0Vs\&t=260, accessed 23 Dec 2020.

[446] https://www.greencarreports.com/news/1127669_electric-jeeps-reportedly-coming-to-the-us-will-be-more-capable-than-gas-or-diesel, accessed 23 Dec 2020.

[447] https://www.electrive.com/2018/02/09/subaru-use-prius-technology-new-phev/, accessed 23 Dec 2020.

[448] https://www.sandiegouniontribune.com/cars/sd-ad-au-0310-crosstrekphev-20190226-story.html, accessed 23 Dec 2020

[449] https://www.greencarreports.com/news/1128790_battery-supply-issue-toyota-rav4-prime-dealers-marking-up, accessed 23 Dec 2020.

[450] https://www.p2enesol.com/wp-content/uploads/2020/10/20201006_NR_EnhanceDomesticProduction_EN.pdf, accessed 23 Dec 2020. 




\section{Argonne}

\section{Energy Systems Division}

Argonne National Laboratory

9700 South Cass Avenue, Bldg. 362

Lemont, IL 60439-4854

www.anl.gov 